
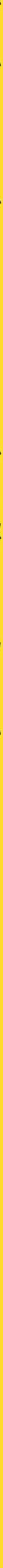

INDIAN INSTITUTE FOR

HUMAN SETTLEMENTS

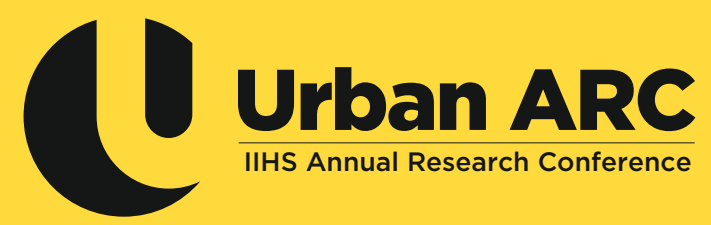




\section{DESIGN \& LAYOUT}

Vikrant M S, Nawaz Khan, IIHS Design Team

\section{COPY EDITING AND REFERENCE SUPPORT}

Mandara Vishwanath, IIHS Word Lab

Tanvi Bhatikar, IIHS Academics and Research

Shalini B G, IIHS Library Team

B. Preedip Balaji, IIHS Library Team

Vinay M S, IIHS Library Team

Anitha K V, IIHS Library Team

Amrutraj R Benahal, IIHS Library Team

Raja P, IIHS Library Team

Pooja Uniyal, IIHS Library Team

This work is available under the following licence:

All the content created by the author(s) for the purpose of the Conference Proceedings: Urban ARC 2019, City and the Region is copyrighted. For permission to reproduce copyright materials, contact the authors of the copyright and IIHS, noted as the 'Source' on each page. You are free to share, to copy, distribute and transmit the work under the following conditions:

Attribution: You must attribute the work in the manner specified by the author or licensor (but not in any way that suggests that the author endorses you/your use of the work).

Non-commercial: You shall not use this work for commercial purposes.

Restrictions on use: The content of this work shall not be modified, edited or altered in any manner without prior written permission of IIHS.

With the understanding that:

Public Domain - Where the work or any elements is in the public domain under applicable law, that status is in no way affected by the licence.

Other Rights - In no way are any of the following rights affected by the licence:

Your fair dealing or fair use rights, or other applicable copyright exceptions and limitations;

The author's moral rights;

Rights other persons may have either in the work itself or in how the work is used, such as publicity or privacy rights.

Explanation: "Work" means the literary and/or artistic work offered under the terms of this license including without limitation any production in the literary, scientific and artistic domain, whatever may be the mode or form of its expression including digital form, such as a book, pamphlet and other writing; a work of drawing, painting, architecture, sculpture, engraving or lithography; a photographic work to which are assimilated works expressed by a process analogous to photography; a work of applied art; an illustration, map, plan, sketch or three- dimensional work relative to geography, topography, architecture or science; a performance; a broadcast; a phonogram; a compilation of data to the extent it is protected as a copyrightable work.

Trademarks: The logos and names of the organisers on the Conference Proceedings: Urban ARC 2019, City and the Region are trademarks of the organisation. Use, reproduction, copying or redistribution of trademarks, without written permission of the logo/name's respective owner is prohibited. The IIHS logo in the Conference Proceedings: Urban ARC 2019, City and the Region is a trademark of IIHS. b. Translation: Where a translation of this work has been created by a third party, prior written permission must be obtained from IIHS. Attribution to IIHS shall be accompanied by the following disclaimer:

"All rights in relation to the material contained in the original work vest with the Indian Institute for Human Settlements (IIHS)."

c. Adaptation: Where an adaptation of the original work has been created, prior written permission must be obtained from IIHS. Attribution to IIHS shall be accompanied by the following disclaimer:

" All rights in relation to the material contained in the original work vest with the Indian Institute for Human Settlements (IIHS).

This work is an adaptation of the original work created by IIHS. IIHS does not endorse the modified content or views/opinions contained in this adaptation in any manner."

d. Third Party Content: This work contains third party owned material which has been duly attributed by IIHS. It is the responsibility of the user to determine the requirements for permission and obtain such permission from the respective copyright owner(s) in the event of use/reuse of third party owned material that constitutes a component of this work. Examples of components may include, but are not limited to, tables or figures. IIHS shall not be liable for any claims arising out of the infringement of material owned by a third party as a result of use/reuse by a user.

e. Citation: Please cite the work as follows:

Papers: Mosaine, N. (2018). Governing the periphery of the Gauteng City-Region, South Africa, Urban ARC City and the Region, Indian Institute for Human Settlements, Bengaluru, 10 January. Bengaluru: Indian Institute for Human Settlements

Conference Proceedings: Urban ARC City and the Region 2019, Indian Institute for Human Settlements, Bengaluru, India, 22-022019

\section{f. Cover and interior design:}

All images that appear in this work have been used with the permission of the creator. For further use/reuse, relevant permission must be obtained from the creator.

g. ISBN (Paperback): 9789387315648

h. DOI: https://doi.org/10.24943/9789387315648

All queries on rights and licenses should be addressed to: library@iihs.ac.in. 


\section{(luranan ARC \\ City and the Region}

Scholarship on the relationship between cities and their surrounding regions has a long history, dating back at least to MacKinner's conceptualisation of London as a city-region in 1902. Since then, much research has been dedicated to understanding the linkages which exist between the two. Over time, these conceptualisations have been challenged, reimagined, and redrawn, particularly as studies of cities have extended to the global South.

In India, cyclical flow of rural residents to and from urban areas for work has been recognised, reframing questions of urban housing, employment, social security, residency, and citizen rights. Migration to cities allows for strong links to persist with certain regions, with new migrants utilising networks of families and friends to establish themselves in cities.

Additionally, the spatial organisation of economies around nodes, originally emerging within economic plans, is now acknowledged by geographers, via ideas of hierarchic regional and locational systems.

The third edition of Urban ARC sought to examine and unpack themes around the city and region by exploring a wide-range of intersections - sectoral, disciplinary, methodological and geographic. The conference was held from 10 to 12 January 2019 at the IIHS Bengaluru City Campus. We received 245 applications from scholars and practitioners across leading local and global universities, out of which, 33 individual papers and 3 panel submissions were selected for the conference.

These Conference Proceedings feature the extended abstracts submitted by the selected participants for Urban ARC 2019. 


\section{Day 1 | 10 January 2019}
$8.30 \mathrm{am}-9.00 \mathrm{am}$
$9.00 \mathrm{am}-9.30 \mathrm{am}$
Session 1
Registration
Opening address

\section{Panel 1: Governing the Urban}

$9.30 \mathrm{am}-11.00 \mathrm{am}$
Governing the periphery of the Gauteng City-Region, South Africa Ngaka Mosiane, Gauteng City-Region Observatory

The exceptional millennial city? An understanding of the planning and governance of Gurugram

Sumedha Priyadarshini, Tata Institute of Social Sciences

Speculating governance: The new normal?

Triveni Prasad Nanda and Aparna Soni, RICS School of Built Environment, Amity University

Community governance of urban wetlands

Arjun Malhotra, Azim Premji University

BREAK: $11.00 \mathrm{am}-11.30 \mathrm{am}$

\section{Session 2}

$11.30 \mathrm{am}-1.00 \mathrm{pm}$
Panel 2: Exploring social identity and culture: Perspectives from Delhi, and Kolkata

Menus matter: Examining class and Bengali cuisine culture through restaurant menus in Kolkata

Runa Das Chaudhuri, University of Calcutta

Fear, activism and formation of counter-urban consciousness:

Experiencing Delhi from the margins, a case of Kathputli colony Rajarshee Choudhury, Jawaharlal Nehru University

Exploring identity and space through the study of housing rental market in Delhi

Asaf Ali Lone, Centre for Public Interest Law, Jindal Global Law School

LUNCH: 1.00 pm - 2.30 pm

\section{Session 3}

$2.30 \mathrm{pm}-4: 00 \mathrm{pm}$

\section{Panel 3: Infrastructure and the urban region}

Challenging inert flows between the city and the region: The canals and the brick kilns of Gurugram and Sonepat

Pratik Mishra, Kings College, London

Lost opportunities: A case study of Khushkhera-Neemrana-Bhiwadi Investment Region

Druti Gangwar and Ridima Kanwal, School of Planning and Architecture, Bhopal

The rescaling of the state in the Dholera Smart City

Rakib Akhtar, University of Oxford

Citizenship at the margins: Exploring slum rehabilitation in an urban fishermen settlement in Kerala

Aarathi G, Centre for Development Studies 


\section{Session 4}

$4.30 \mathrm{pm}-6.00 \mathrm{pm}$

\section{Panel 4: Urban Systems and Services}

Poverty and transport accessibility in Bangalore: The need for a gendered perspective

Pooja Sastry

Commuter railways and development of city-region: A study from eastern India

Bhaswati Mondal and Gopa Samanta, The University of Burdwan

Consumption and waste metabolism: Determinant changes in consumption patterns impact the generation of solid waste in the peri-urban areas of Quito

Adriana Mejía Artieda, FLASCO

Symbiosis or parasitism? Exploring the city-region relationship through the support capacity

Oscar Mejía-Rivera, Carlos Cadena-Gaitán and Santiago Mejía-Dugand, Universidad EAFIT

Delivery of water and sanitation public services under Swachh Bharat Mission Urban (SBM-U) at New Delhi railway station

Deepak Kumar, Tata Institute of Social Sciences

\section{Day 2 | 11 January 2019}

\section{$8.30 \mathrm{am}-9.00 \mathrm{am}$}

Session 1

$9.30 \mathrm{am}-11.00 \mathrm{am}$

\section{Registration}

\section{Panel 5: Food systems across scales}

Small farms around Bengaluru: Growing money at the cost of food and environment Sheetal Patil, Seema Purushothaman, Raghvendra Vanjari, Dhanya B and Shwetha A R, Azim Premji University

Remaking town and hinterland: Reshaping palates and transforming diets in western Awadh, Uttar Pradesh, India

Richa Kumar, IIT Delhi and Richa Singh, Sudha Nagavarapu and Surbala Vaish, Sangtin, Sitapur

The data of food: E-Commerce business to business firms and their shaping of food supply chains in Karnataka

Natasha S K, Shwetha Govindan and Keerthana Jagadeesh, Indian Institute for Human Settlements

Millet trails, from market-town to city-region: Exploring sustainable food narratives in Bangalore

Salila Vanka, R V College of Architecture and Dwijendranath Guru, The Millet Foundation

BREAK: $11.00 \mathrm{am}-11.30 \mathrm{am}$

\section{Session 2}

$11.30 \mathrm{am}-1.00 \mathrm{pm}$

\section{Panel 6: Land use and planning}

Looking through the towns and cities of Calcutta in Kolkata Sarani Khatua, University of Calcutta

Speculating on Bangalore's urbanism: Land transitions at the city's edge Carol Upadhya, Hemangini Gupta, Sachinkumar Rathod and Priyanka Krishna, National Institute for Advanced Studies 
A Study of the Mhalunge-Maan town planning scheme: Juxtaposing the scope for public negotiation under land pooling with the use of eminent domain under land acquisition

Varun Panickar, Indian Institute for Human Settlements

Inter-relation between landform characteristics and hierarchy of street network taking the case of Greater Bengaluru Metropolitan region Jeeno George, BMS College of Architecture

LUNCH: $1.00 \mathrm{pm}-2.30 \mathrm{pm}$

\section{Session 3}

$2.30 \mathrm{pm}-4.00 \mathrm{pm}$

\section{Panel 7: Global perspectives on urban transformations}

A cross - sectional and spatial analysis of the prevalence of multimorbidity and its association with socioeconomic disadvantage in South Africa: A comparison between 2008 and 2012.

Amy Weimann, University of Cape Town, Dajun Dai, Georgia State University and Tolu Oni, University of Cambridge

Urban transformation in the Pearl River Delta region Chetan Kulkarni, University of Texas at Austin

Urban public finance: A case study of Kisumu Liza Cirolia, African Centre for Cities

Urbanisation in monsoon Asia and the agrarian question Stephen Cairns, Future Cities Laboratory, ETH Zürich

BREAK: $4.00 \mathrm{pm}-4.30 \mathrm{pm}$

\section{Session 4}

$4.30 \mathrm{pm}-6.00 \mathrm{pm}$
Panel 8: Knowledge-based economies, innovation networks, and regional development in India

Studying the location pattern of knowledge clusters and networks and its Influence in an urban region

Arindam Biswas and Hariharan Arun Natarajan, Indian Institute of Technology, Roorkee

Industrial agglomeration in a globalised economy: The case of Ahmedabad metropolitan area, India Anil Kumar Roy and Charmy Shah, CEPT University

A regional variant of Silicon Valley?: Bangalore's role in the innovation networks of the global information economy Balaji Parthasarathy, IIIT Bangalore Indian Univer(c)ities: Knowledge and its effects on city-regions Kala S Sridhar, Institute for Social and Economic Change Planning beyond boundaries for creating smart regions Vinita Yadav, School of Planning and Architecture, New Delhi 


\section{Day 3 | 12 January 2019}

$8.30 \mathrm{am}-9.00 \mathrm{am}$ Registration

Session 1

$9.30 \mathrm{am}-11.00 \mathrm{am}$
Panel 9: Livelihoods, migration, and the urban economy

Networks, mobilities and segmentation in small city labour markets Mukta Naik, Pranav Kuttaiah and Eesha Kunduri, Centre for Policy Research

'Feet in both places': Precarious migrant lives in a global city Swathi Shivanand, Jawaharlal Nehru University

Architecture and the urban setting of bazaar: Defining socio-economic city-region linkages in the process of urbanisation in India, case of Mullickghat flower market, Kolkata

Somrita Bandyopadhyay, School of Planning and Architecture, New Delhi

Planning strategies for upliftment of handicraft clusters and their workers: A case of Lucknow cluster of Avadh region

Amrita Rastogi, Institute for Spatial Planning and Environment Research

BREAK: $11.00 \mathrm{am}$ - $11.30 \mathrm{am}$

\section{Session 2}

$11.30 \mathrm{am}-1.00 \mathrm{pm}$
Panel 10: Evolving urban economies, their impact on health and proposed solutions

The challenge initiative for healthy cities

Mukesh Kumar Sharma, Population Services International

Building healthy cities

Damodar Bachani, John Snow India Private Limited

Ensuring equitable, accessible, and appropriate healthcare for the urban population: A technology and innovation-driven model through a network of neighbourhood clinics (mohalla clinics) in Delhi Anand Panjiyar, WISH Foundation India

PAHAL: An ecosystem approach

LM Singh, PAHAL, IPE Global

LUNCH: 1.00 pm - 2.30 pm

Session 3

$2.30 \mathrm{pm}-4.00 \mathrm{pm}$

\section{Panel 11: Smart Cities and urban regions}

Planetary urbanization, region and India's Smart Cities Mission Glen David Kuecker and Tristan Stamets, DePauw University

Smart Cities and citizenship

Deepak Kumar, Jawaharlal Nehru University

Smart Cities programme, Schumpeterian Logic or urban entrepreneurialism? Reading the governmentality of urban futures in India

Purushottam Kesar, Radboud University

Strategies for sustainable neighbourhood planning in a Smart City:

A Case of Pattoor, Thiruvananthapuram

Vijaya Nhaloor, Marian College of Architecture and Planning

BREAK: $4.00 \mathrm{pm}-4.30 \mathrm{pm}$

\section{Session 4}

$4.30 \mathrm{pm}-6.00 \mathrm{pm}$

\section{Closing Panel}

Special invited panel 


\section{Table of Contents}

Introduction.

Schedule. ..iv

Panel 1: Governing the Urban. 11

Community governance of urban wetlands 12

Governing the periphery of the Gauteng City-Region, South Africa. 19

The exceptional millennial city? An understanding of the planning and governance of Gurugram 23

Panel 2: Exploring social identity and culture: Perspectives from Delhi and Kolkata 29

Exploring identity and space through the study of housing rental market in Delhi 30

Fear, activism and formation of counter-urban consciousness: Experiencing Delhi from the margins, a case of Kathputli Colony

Menus matter: Examining class and Bengali cuisine culture through restaurant menus in Kolkata ....... 39

Panel 3: Infrastructure and the urban region

Challenging inert flows between the city and the region: The canals and the brick kilns of Gurugram and Sonepat.

Citizenship at the margins: Exploring slum rehabilitation in an urban fishermen settlement in Kerala. 49

Lost opportunities: A case study of Khushkhera-Neemrana-Bhiwadi investment region . 53

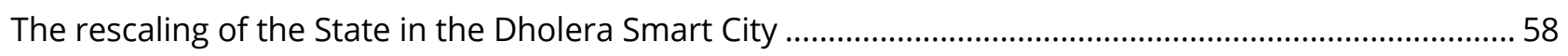

Panel 4: Urban systems and services

Delivery of water and sanitation public services under Swachh Bharat Mission-Urban (SBM-U) at New

Delhi railway station 66

Poverty and transport accessibility in Bengaluru: The need for a gendered perspective.

Consumption and waste metabolism: Determinant changes in consumption patterns impact the generation of solid waste in the Peri-Urban areas of Quito..

Symbiosis or parasitism? Exploring the city-region relationship through the support capacity .78

Panel 5: Food systems across scales .83

Panel Abstract 84

Small farms around Bengaluru: Growing money at the cost of food and environment...... .88

Remaking town and hinterland: Reshaping palates and transforming diets in western Awadh, Uttar Pradesh, India

The data of food: E-commerce business to business firms and their shaping of food supply chains in Karnataka.

Millet Trails, from market-town to city-region: Exploring sustainable food narratives in Bangalore ...... 96

Panel 6: Land use and planning

A Study of the Mhalunge-Maan town planning scheme: Juxtaposing the scope for public negotiation under land pooling with the use of eminent domain under land acquisition

Looking through the towns and cities of Calcutta in Kolkata...

Speculating on Bangalore's urbanism: Land transitions at the city's edge .. 
Inter-relation between landform characteristics and hierarchy of street network: Taking the case of Greater Bengaluru metropolitan region.

Panel 7: Global perspectives on urban transformations

A cross-sectional and spatial analysis of the prevalence of multimorbidity and its association with socioeconomic disadvantage in South Africa: A comparison between 2008 and 2012.

Urban Public Finance: A Case Study of Kisumu

Urban transformation in the Pearl River Delta

Urbanisation in monsoon Asia and the agrarian question

Panel 8: Knowledge-based economies, innovation networks and regional development in India.

A regional variant of Silicon Valley? Bangalore's role in the innovation networks of the global information economy.....

Indian univer(c)ities: Knowledge and its effects on city regions

Industrial agglomeration in a globalised economy: The case of Ahmedabad metropolitan area, India151 Planning beyond boundaries for creating smart regions.

Panel 9: Livelihoods, migration and the urban economy

'Feet in both places': Precarious migrant lives in a global city

Architecture and the urban setting of bazaar: Defining socio- economic city-region linkages in the process of urbanisation in India: A case of Mullickghat flower market, Kolkata.

Networks, mobilities and segmentation in small city labour markets.

Planning strategies for upliftment of handicraft clusters and their workers: A case of Lucknow cluster of Avadh region

Panel 10: Evolving urban economies, their impact on health and proposed solutions.

Building Healthy Cities: Reducing risk of diseases through multi-sector urban planning......

Ensuring equitable, accessible, and appropriate healthcare for the urban population: A technology-and innovation-driven model through a network of neighbourhood clinics (mohalla clinics) in Delhi ........ 178

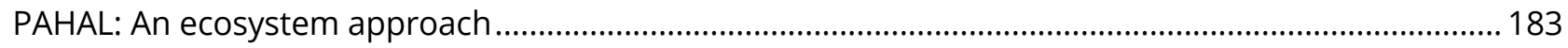

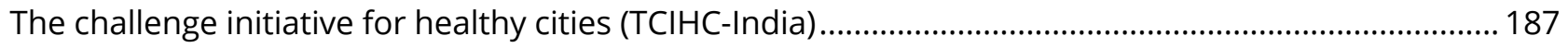

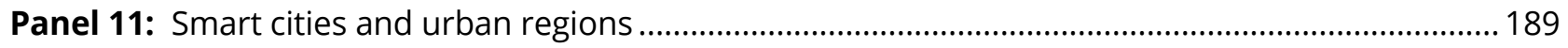

Planetary urbanisation, region and India's Smart Cities Mission .............................................................. 190

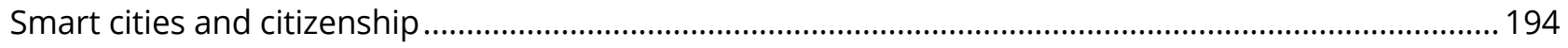

Smart cities programme, Schumpeterian logic or urban entrepreneurialism? Reading the governmentality of urban futures in India. 


\section{List of Figures}

Figure 1. Getis-Ord Gi* hot spot analysis of the age-adjusted prevalence of multimorbidity in the NIDS South African adult sub-sample by district for 2008 and 2012.

Figure 2. Location of Pilot Sponge Cities in China

Figure 3. Digital elevation model of Pearl River Delta.....

\section{List of Tables}

Table 1. indicates a positive impact on the lake; - indicates a negative impact on the lake; indicates no impact on the lake and N.A. indicates that the factor was not found impacting the lake.

Table 2. Age-adjusted prevalence estimates and 95 per cent confidence intervals $(\mathrm{Cl})$ for the South African adult population for 2008 (wave 1) and 2012 (wave 3) using the NIDS

Table 3. Dominant types of industries and selected samples for the study... 


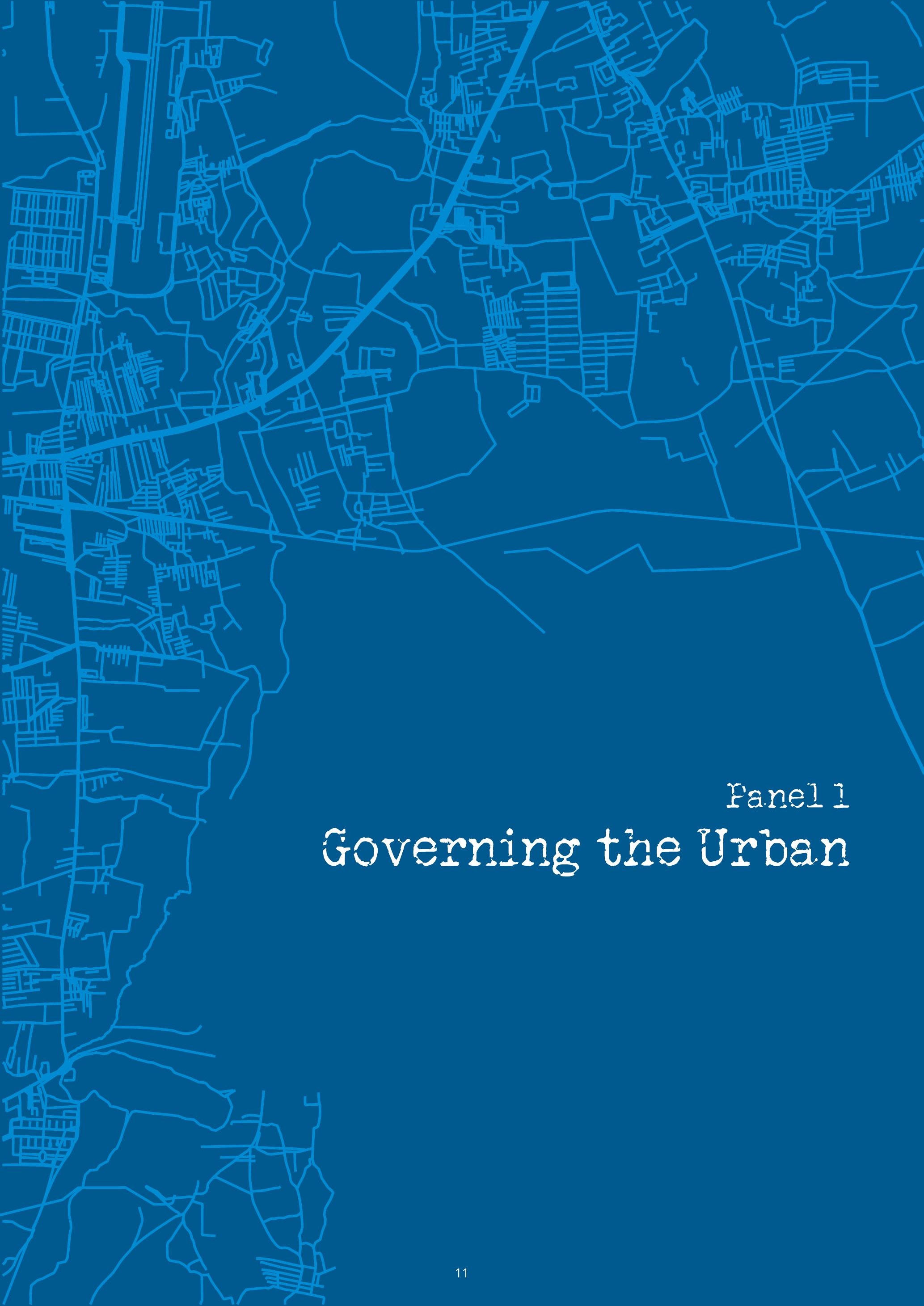




\section{Community governance of urban wetlands}

Arjun Malhotra; Azim Premji University

\section{Introduction}

The last three decades have witnessed an explosion of studies around common property resources (CPRs). However, one major gap in the current literature on CPRs is the lack of research on urban commons (Colding et al., 2013). Urban ecology faces massive pressure due to urbanisation and population growth; on the other hand, natural resources such as urban wetlands also provide crucial ecosystem services [Millennium Ecosystem Assessment (Program), 2005]. The need of the hour is to protect and conserve them to tackle climate change.

This study explores factors that impact the cooperation of the government with local communities for governing urban wetlands in Bengaluru, a city in south India. Urban wetlands play an important social and ecological role [Millennium Ecosystem Assessment (Program), 2005]. However, management of urban wetlands is challenging. Bengaluru, known as the 'Garden City of India', has witnessed tremendous damage to its well-connected system of artificial lakes-a form of urban wetland. Recent efforts by citizen groups to rejuvenate and manage different lakes provide important insights into the fragmented governance of CPRs. The research question for this study is: what factors impact the cooperation of governmental actors with local communities, for collective action in management and rejuvenation of lakes in an urban setting?

\section{Methodology}

Due to a paucity of literature on urban commons, this is an exploratory study. To achieve the objective of this study, existing literature on natural resource management to identify factors that impact the cooperation of the government with local communities was first reviewed, followed by a review of studies on lakes in Bengaluru to identify additional factors. The author also conducted semi-structured interviews with four lake groups (at least two members from each group) that have been engaged in collective action in Bengaluru. Of the four lake groups, two were successful-hereby referred to as successful lake 1 (SL1) and successful lake 2 (SL2); and two were unsuccessful, hereby referred to as unsuccessful lake 1 (UL1) and unsuccessful lake 2 (UL2)_in rejuvenation and management of lakes to identify more factors as well as to validate the factors identified from existing literature. Additionally, the study will also look into how different factors impact successful and unsuccessful lake groups. 


\section{Literature Review}

Coordination and communication between different governance actors has been identified as an important factor that enables collective action for natural resources, both in theoretical models (Ostrom, 2000) and field experiments (Andersson, 2004; Meinzen-Dick, 2007). This factor becomes even more pronounced with the emergence of polycentric forms of governance, (Ostrom, 2010) which rely on nested enterprises (Ostrom, 2007, 2009) where multiple actors at different levels engage in management of natural resources.

While there is a growing recognition that natural resource management requires a more holistic approach with an emphasis on creating institutions that enable collective action, it is also important to recognise that coordination between the multiplicities of actors is also accounted for. One obvious and extremely important actor in such institutional arrangements is the government (Agrawal, 2003; Bardhan, 2000; Meinzen-Dick, 2007). Agrawal and Gibson (1999) claim that governments can resolve intra-community and intercommunity conflicts, provide external intervention to change exploitative norms, provide specialised knowledge, resources and technical support that local communities do not possess.

While the positive effects of government involvement have been highlighted above, it can also have negative effects including resistance to external imposition of rules by communities (Bardhan, 2000; Ostrom, 2000), frequent transfer of government officials, lack of coordination between government and other actors (Andersson, 2004) as well as between different government agencies (Ratner, Mam, \& Halpern, 2014).

The indispensable role played by the government in natural resource management makes it extremely important for other actors to cooperate with them by creating effective channels of communication. Andersson (2004) states that 'for governance actors to be able to cooperate effectively they need to communicate effectively with one another'. However, poor communication between different government agencies across sectors acts as an impediment in the governance of natural resources (Ratner et al., 2014). This lack of communication hinders coordination due to differences in the actors' preferences, interests, disparities in their access to power, resource and information, short tenures of government officials, presence of multiple government agencies (Andersson, 2004) and misaligned political and economic incentives (Gibson and Lehoucq, 2003).

Problems of coordination can be overcome when actors engage in repeated interactions, valuing the future benefits of increased cooperation and are allowed to communicate face-toface. They should be able to discuss optimal joint strategy, exact promises from each other, give verbal tongue lashings and have a richer language structure coupled with the ability to read intonations and body language (Ostrom, 2000).

Based on the above literature review, factors impacting the cooperation of the government chosen for this study are trust and reciprocity (includes repeated interactions and face- to- 
face communication); communication between different government agencies; frequent transfers; and resistance to external imposition of rules. Political and economic incentives were also identified as a factor. However, due to limitation of time, the author did not get the opportunity to interview government officials to understand their perspective behind certain decisions. Hence, these factors were dropped for this study.

\section{Context of Bangalore}

Historically, lakes in Bengaluru were managed by communities. Other than being a source of fresh water, they were also useful for agriculture, drinking, fishing, cattle washing and domestic uses (D'Souza \& Nagendra, 2011; Sundaresan, 2011). As a result, the ecology of the lakes was shaped by different social conceptions and needs of different groups (Unnikrishnan and Nagendra, 2016). Over the years, the city has struggled to balance conservation and management of its resources with urban expansion and economic growth, (Unnikrishnan and Nagendra, 2015) leading to severe pollution and encroachment of lake areas. Additionally, the governance structure shifted from being community managed lakes to a more formal government structure during colonial times, which continued after independence with the number of government departments increasing progressively. This was accompanied by increasing migration, erosion of traditional communities, and changes in land-use pattern (D'Souza \& Nagendra, 2011; Sundaresan, 2011).

The focus in Bengaluru is often on economic growth, while conservation and management of natural resources takes a back-seat (Sundaresan, 2011; Unnikrishnan and Nagendra, 2016). Focussing on economic growth alone points to misaligned political and economic incentives for conserving natural resources. However, this can be tackled by mounting pressure on government officials through lake groups and civil society organisations as was done in the case of Guatemala (Gibson and Lehoucq, 2003) and previously in Bengaluru (D'Souza \& Nagendra, 2011; Sundaresan, 2011). This section adds another factor: the ability to apply pressure on the government.

\section{Findings}

In addition to the factors identified above, the interviews revealed four more factors that can impact cooperation of the government. These factors are: presence of a committed government official in a position of power, political support, delayed action and deliberate nonaction, and downward accountability. The table below shows how the factors impacted the four lakes.

\begin{tabular}{|l|l|l|l|l|}
\hline Factor/Lake & SL1 & SL2 & UL1 & UL2 \\
\hline Trust and reciprocity & + & + & - & - \\
\hline $\begin{array}{l}\text { Communication between } \\
\text { different government agencies }\end{array}$ & - & N.A. & N.A. & - \\
\hline Frequent transfers & N.A. & - & N.A. & - \\
\hline
\end{tabular}




\begin{tabular}{|c|c|c|c|c|}
\hline Factor/Lake & SL1 & SL2 & UL1 & UL2 \\
\hline $\begin{array}{l}\text { Resistance to external } \\
\text { imposition of rules }\end{array}$ & - & - & - & - \\
\hline $\begin{array}{l}\text { Ability to apply pressure on the } \\
\text { government }\end{array}$ & + & + & - & . \\
\hline $\begin{array}{l}\text { Presence of a committed } \\
\text { government official in a position } \\
\text { of power }\end{array}$ & + & + & - & - \\
\hline Political support & N.A. & N.A. & - & . \\
\hline $\begin{array}{l}\text { Delayed action and deliberate } \\
\text { non-action }\end{array}$ & - & - & - & - \\
\hline Downward accountability & - & - & - & - \\
\hline
\end{tabular}

Table $1^{*}+$ indicates a positive impact on the lake; - indicates a negative impact on the lake; indicates no impact on the lake and N.A. indicates that the factor was not found impacting the lake.

In the case of successful lakes, it was clear that their efforts in rejuvenating and managing the lakes were strengthened by the presence of a committed government official in a position of power as well as trust and reciprocity. In both cases, the official was present in the government agency which had been mandated to manage the lake. On the other hand, UL 1 neither had the support of the government agency responsible for managing the lake nor any official in it. UL 2 was able to garner the support of a junior officer in the government agency, but that officer could not wield significant power, thereby diluting his ability to influence governmental decisions.

The findings also reveal that trust and reciprocity can be enhanced without face-to-face communication but not without repeated interactions. Establishing a point of contact is equally effective in enhancing trust and reciprocity as face-to-face communication, which both the successful lakes were able to do. Repeated interaction is still an important factor that impacts trust and reciprocity. While all the groups tried to apply pressure on the government through public events like signature campaigns, walkathons, human chain, and by repeatedly visiting government agencies, the effect was positive for only the successful groups.

All four lake groups suffered due to resistance to external imposition of rules. UL 1 faced resistance from elected representatives. Despite receiving political support, UL 2 suffered from resistance to rejuvenate the lake, mainly by people or institution(s) wanting to make economic gains from high land prices around the lake. This problem was further compounded by its invisible presence. The lake group did not know the people or the institution(s) that were resisting rejuvenation of the lake.

Delayed action and deliberate non-action was a general issue that plagued all four lakes. The government agencies delayed taking action against encroachments that the lake groups informed them about. In some cases, the government would respond after the encroachment 
construction was complete, by which time any action would be ineffective. Additionally, for the two unsuccessful lakes, the concerned government agencies never conducted a land survey of the lakes to demarcate their boundary despite several requests from the lake groups. A review of literature on CPR clearly highlights the importance of the presence of clearly defined boundaries for successful management of lakes. This non-action by government agencies was a major hindrance for the unsuccessful lakes.

The lack of downward accountability was another issue that all the lake groups identified. In all cases the government agencies would give verbal commitment to take action on a complaint but rarely took any concrete steps. This also meant that the ability to put pressure on the government had limited impact. In some cases, the local ombudsman was able to put some pressure, but that was inadequate. The lack of political support also limited the impact of the pressure on the government as public events like walkathons, human chain, and a signature campaign did not solicit adequate response from the elected representatives. This also points to the fact that misaligned political incentives tend to dilute the effect of citizens applying pressure on the government to take action. Amongst other factors, lack of communication between different government departments was an issue for SL 1 and UL 4 while frequent transfers of officials were issues for SL 2 and UL 2.

\section{Conclusion}

The study shows that fragmented governance negatively impacts management of lakes due to problems associated with cooperation. The absence of a clear policy on management of lakes has led to a dilution in downward accountability of different government departments leading to delayed action and deliberate non-action on their part. Additionally, trust and reciprocity along with the presence of a committed government official are two of the most important factors that can determine the success or failure of natural resource management in an urban setting.

The study reveals a few puzzles too. The puzzles relate to the interactional effect of different factors with each other. In case of UL 2, why was it that despite enjoying political support and applying pressure on the government, the lake group was unable to rejuvenate the lake? Did resistance to their efforts completely undermine all other factors? Or was it just the absence of a committed government official who would be apathetic to the cause of saving the lake, undermining all other efforts? While the study discusses some of the interactions, more research needs to be conducted to investigate it further.

\section{References}

Agrawal, A. (2003). Sustainable governance of common-pool resources: Context, methods, and politics. Annual Review of Anthropology, 32, 243-262.

https://doi.org/10.1146/annurev.anthro.32.061002.093112

Agrawal, A., \& Gibson, C. C. (1999). Enchantment and disenchantment: The role of community in natural resource conservation. World Development, 27(4), 629- 649. 
https://doi.org/10.1016/S0305-750X(98)00161-2

Andersson, K. P. (2004). Who talks with whom? The role of repeated interactions in decentralized forest governance. World Development, 32(2), 233-249.

https://doi.org/10.1016/j.worlddev.2003.07.007

Bardhan, P. (2000). Irrigation and cooperation: An empirical analysis of 48 irrigation communities in South India. Economic Development and Cultural Change, 48(4), 847-865. https://doi.org/10.1086/452480

Colding, J., Barthel, S., Bendt, P., Snep, R., van der Knaap, W., \& Ernstson, H. (2013). Urban green commons: Insights on urban common property systems. Global Environmental Change, 23(5), 1039-1051. https://doi.org/10.1016/j.gloenvcha.2013.05.006

D'Souza, R., \& Nagendra, H. (2011). Changes in public commons as a consequence of urbanization: The Agara Lake in Bangalore, India. Environmental Management, 47(5), 840850. https://doi.org/10.1007/s00267-011-9658-8

Gibson, C. C., \& Lehoucq, F. E. (2003). The local politics of decentralized environmental policy in Guatemala. The Journal of Environment \& Development, 12(1), 28-49.

https://doi.org/10.1177/1070496502250437

Meinzen-Dick, R. (2007). Beyond panaceas in water institutions. Proceedings of the National Academy of Sciences, 104(39), 15200-15205. https://doi.org/10.1073/pnas.0702296104 Millennium Ecosystem Assessment (Program). (2005). Ecosystems and human well-being: Wetlands and water synthesis: a report of the Millennium Ecosystem Assessment. Washington, DC: World Resources Institute.

Nagendra, H., \& Ostrom, E. (2014). Applying the social-ecological system framework to the diagnosis of urban lake commons in Bangalore, India. Ecology and Society, 19(2). https://doi.org/10.5751/ES-06582-190267

Ostrom, E. (2007). A diagnostic approach for going beyond panaceas. Proceedings of the National Academy of Sciences, 104(39), 15181-15187. https://doi.org/10.1073/pnas.0702288104

Ostrom, E. (2009). A general framework for analyzing sustainability of social- ecological systems. Science, 325(5939), 419-422. https://doi.org/10.1126/science.1172133

Ostrom, E. (2000). Collective action and the evolution of social norms. The Journal of Economic Perspectives, 14(3), 137-158. https://doi.org/10.1257/jep.14.3.137

Ostrom, E. (2010). Beyond markets and states: Polycentric governance of complex economic systems. The American Economic Review, 100(3), 641-672. https://doi.org/10.1257/aer.100.3.641

Ratner, B. D., Mam, K., \& Halpern, G. (2014). Collaborating for resilience: Conflict, collective action, and transformation on Cambodia's Tonle Sap Lake. Ecology and Society, 19(3). https://doi.org/10.5751/ES-06400-190331

Sundaresan, J. (2011). Planning as commoning: Transformation of a Bangalore Lake. Economic and Political Weekly, 46(50), 71-79.

Unnikrishnan, H., \& Nagendra, H. (2015). Privatizing the commons: Impact on ecosystem services in Bangalore's lakes. Urban Ecosystems, 18(2), 613-632.

https://doi.org/10.1007/s11252-014-0401-0 
Unnikrishnan, H., \& Nagendra, H. (2016). Contested urban commons: Mapping the transition of a lake to a sports stadium in Bangalore. International Journal of the Commons, 10(1), 265-293. https://doi.org/10.18352/ijc.616 


\section{Governing the periphery of the Gauteng City-Region, South Africa}

Ngaka Mosiane; Gauteng City-Region Observatory

This paper will discuss the state of governance in the peripheries of the Gauteng city-region, focussing on agricultural activities as well as transportation and planning projects. It draws on qualitative and quantitative data, besides secondary materials. The paper will locate the challenges for delivering the above-mentioned projects in the dynamics of local forms of governance, the inequitable administrative capacities and the structuring forces of labour and land markets. Such inequities are reproduced in the mismatch between territorial boundaries and institutional authorities, with the enterprise of governance itself being made to mediate related disparities and mismatches. The complexities of governance implied here will frame the discussion of the above-mentioned development projects as selected sites of negotiated development practices, where differentially positioned actors may form coalitions for an agenda of the Gauteng city-region that is both 'ordinary' and 'regionally competitive'. The argument for the latter is based on the potential for this city-region to build a dynamic economy while creatively attending to the ordinary qualities. The proposition for an ordinary and a competitive city-region is also based on the legislative autonomy of the South African subnational state spheres, which itself locates the governance of the city-region in its institutional intensity - the co-presence of multiple spaces, multiple times and multiple webs of relations-where players are able to represent their bureaucratic procedures, electoral base, institutional interest, mandates, and even signal its internal politics.

One site for possible negotiated development practices is the Mabopane Station precinct project. It is being carried out separately by the City of Tshwane that is building the bus and taxi ranks, while the Passenger Rail Agency of South Africa (PRASA) upgrades the train station. The Station precinct can become a sustainable urban core and transport destination, rather than just a thoroughfare. Additionally, the development possibilities associated with the mobility of commuters may stitch together the historically divided Soshanguve and Mabopane/Winterveld areas. Nonetheless, the City of Tshwane, PRASA and private developers have adopted an individual/insulated approach to development, the result of which does not only constrain the area's walkability and vehicular access, but also poses daily dangers to pedestrians (muggings and rapes). A suggested approach is the use of the 'street model' as a structuring element of the Mabopane Station precinct, as part of the northern development corridor. The street can be used to determine the road hierarchy, starting with a spine road as a collector that ties shorter streets together (Horner, 2012).

What is emerging in the analysis, though, is that the discontinuous and indirect ways in which roads M35 and R80 that link the townships of Soshanguve and Mabopane, and Winterveld to the city core and local train stations run outside, parallel to these townships. Such configuration of roads does not augur well for corridor formation. Indeed, the abovementioned roads constitute a relatively 'higher spatial value' for the townships in question in 
terms of their global accessibility - such roads create the major primary spines of longdistance mobility, enabling the area to be accessed, at broader scale, from most directions. That said, if the spine roads are intended for fast-paced mobility between two points, the street network can shape the neighbourhood character. The street can be used to shape the identity of an area (or a land parcel) through land-use zoning and town planning controls. Such guidelines may influence an area's population density, its potential for public transportation as well as its movement patterns (busy or quiet streets), all of which can be exploited for various land uses. In that sense, the Mabopane Station precinct can be laced with fine- and course-grained grids that encourage its vehicular accessibility and walkability. While pedestrian activity is useful for browsing and comparison shopping, the moving trade (vehicular accessibility and walkability) in general generate exchange.

One other site for possible negotiated development practices is the Moloto Corridor initiative. The Moloto road (R573) has come to be dubbed the 'road of death', with about 20 road accidents reported per month between 2012 and 2014, 39 per cent of which involved pedestrians. It is for reasons of the costs of the Moloto road (time, money, and reduced quality of life) that the need arose to make it cost-effective through the development of the Moloto Corridor. The project will see the building of the $198 \mathrm{~km}$. double-track railway line and 24 stations; the upgrading of the $134 \mathrm{~km}$. road (R573) as well as the development of $240 \mathrm{~km}$. local feeder roads. The project will ultimately connect rail, road, and land developments. The analysis so far seems to show that the national Department of Transport has not been able to persuade its counterparts in the National Treasury, human settlements, economic development, or even the Gauteng province to start with the Moloto corridor development. Even at the political or the national strategic levels, where respectively, the Cabinet or the Presidential Infrastructure Coordinating Commission (PICC) have approved the Moloto project, it has only taken off in very small ways (only certain parts of the road are being upgraded).

The paper will develop an argument that the state is a crucial player in the delivery of a cityregion that is both 'ordinary' and 'regionally competitive' (in agricultural development terms). This is in relation to a process where non-state actors are involved. The state is better positioned to mobilise an amalgam of interests behind a more or less coherent line of action (region-wide agricultural development priorities). Nonetheless, the state has not used such leverage. Similarly, the projects of the Moloto Corridor and Mabopane Station precinct show that in cases where it is mainly the state organisations that interact on projects that cut across responsibilities and/or physical space, coordination is equally a challenge. A significant element of this governance challenge is that the National Treasury can use the state regulations in particular ways - to both enforce a certain development approach or to rein in the unfettered exercise of power pursuing a particular approach. Additionally, in a political system where subnational state spheres have relative autonomy, local/regional leaders are able to align political and developmental goals in key sectors: to deliver on short-term political gains (patronage) in a way that does not compromise the delivery of services/long- term 
development goals. This power dynamic opens up space for political competition: a different political party (or a coalition of parties) can use its electoral support to demonstrate better performance in the delivery of public goods, thereby increase the political cost of poor service delivery and associated practices of collective responsibility and limited accountability.

\section{References}

African Farmers Association of South Africa (AFSA). (2016). Draft Tshwane agricultural sectoral profile. Report of the city of Tshwane metropolitan municipality.

Allen, J. \& Cochrane, A. (2010). Assemblages of state power: Topological shifts in the organisation of government and politics. Antipode, 42(5), 1071-1089.

https://doi.org/10.1111/j.1467-8330.2010.00794.x

Cheeseman, N. \& de Gramont D. (2017). Managing a mega-city: Learning lessons from Lagos. Oxford Review of Economic Policy, 33(3), 457-477. https://doi.org/10.1093/oxrep/grx033

City of Johannesburg Metropolitan Municipality. (2016). Spatial development framework 2040. Johannesburg, South Africa: Department of Development Planning. Retrieved from http://www.parkview.org.za/docs/townplanning/Johannesburg\%20Spatial\%20Developm ent\%20Framework\%202040.pdf

Cochrane, A. (2010). Exploring the regional politics of 'sustainability': Making up sustainable communities in the South-East of England. Environmental Policy and Governance, 20, 370 381. https://doi.org/10.1002/eet.556

Council for Scientific and Industrial Research. (2016). Gauteng housing demand and backlog findings report, phases 3-5. Johannesburg, South Africa: Gauteng Department of Human Settlement

Gastrow, C. (2016). Aesthetic dissent: Urban redevelopment and political belonging in Luanda, Angola. Antipode, 49(2), 377-396. https://doi.org/10.1111/anti.12276

Gauteng Department of Roads and Transport. (2013). 25-Year integrated transport master plan annexure J: strategic road network. Johannesburg, South Africa: Gauteng Department of Roads and Transport. Retrieved from http://workspace.unpan.org/sites/internet/Documents/UNPAN93875.pdf

Harrison, P. \& Dinath, Y. (2017). Gauteng - on the edge. In S. Peberdy, P. Harrison \& Y. Dinath. Uneven spaces: Core and periphery in the Gauteng city-region. Johannesburg, South Africa: GCRO.

Horner, B. (2012). The Royal Bafokeng nation: Cultural identity and spatial expression. In Greene, M., Reyes, J. \& Castro, A. (Eds.), Proceedings: Eighth international space syntax symposium (Paper Ref \#8067). Santiago de Chile: PUC.

Jonas, A. \& Ward, K. (2007). Introduction to a debate on city-regions: New geographies of governance, democracy and social reproduction. International Journal of Urban and Regional Research, 31(1), 169-178. https://doi.org/10.1111/j.1468-2427.2007.00711.x MacKinnon, D. \& Shaw, J. (2010). New state spaces, agency, and scale: Devolution and the regionalisation of transport governance in Scotland. Antipode, 42(5), 1226-1252. https://doi.org/10.1111/j.1467-8330.2010.00800.x

Nick, G. (2010). Tracing imaginations of the state: The spatial consequences of different state 
concepts among asylum activists organisation. Antipode, 42(5), 1048-1070. https://doi.org/10.1111/j.1467-8330.2010.00793.x

Peberdy, S. (2017). Uneven development - core and periphery in Gauteng. In S. Peberdy, P. Harrison \& Y. Dinath. Uneven spaces: Core and periphery in the Gauteng city-region. Johannesburg, South Africa: GCRO.

RSA. 2015. Moloto Corridor: Review of Feasibility Study and Identifying Other Potential Options. GTAC/AECOM Contract number 2015/07/895/134/GTAC.

RSA, 2014. National Department of Transport Feasibility Study for the Moloto Development Corridor. SMEC, Cliffe Dekker Hofmeyr, Deloitte and Touche.

Schroeder, L. (2003). Municipal powers and functions: The assignment question. In R. Bahl \& P. Smoke (Eds), Restructuring local government in developing countries: Lessons from South Africa (pp. 23-69). Cheltenham, UK: Edward Elgar Publishing.

Socio-Economic Rights Institute. (2016). Edged out: Spatial mismatch and spatial justice in South Africa's main urban areas. Johannesburg, South Africa: SERI. Retrieved from http://www.seri-sa.org/images/SERI_Edged_out_report_Final_high_res.pdf

Storper, M. (2014). Governing large metropolis. Territory, Politics, Governance, 2(2), 115-134. https://doi.org/10.1080/21622671.2014.919874 


\section{The exceptional millennial city? An understanding of the planning and governance of Gurugram}

Sumedha Priyadarshini; Tata Institute of Social Sciences

\section{Introduction}

Gurugram, the millennial city situated in the state of Haryana, is part of the National Capital Region of Delhi. The city is known for its skyscrapers, corporate offices, cyber city and popular recreational spaces. With its extreme weather conditions and fast paced city life, the buzzing city hosts over 20 million people. The cityscape of Gurugram reminds one of the growing Indian economy and hides away the existing poverty of the city behind the booming office hub. The city has been termed as an experimental city in terms of flexible planning (Gururani, 2015) and involvement of private agencies at various levels in the course of governance. This paper attempts to examine the exceptionality in the planning and governance of Delhi NCR, comprising the deflected migrant population from the metropolis, through a case study around the sanitation facility in Sector 15 part 2, situated along the $\mathrm{NH}-8$, of the city.

While exploring the historiography of Gurugram and its dependence on as well as independence from Delhi, the paper moves on to developing an understanding of how the sanitation plan for the sector was formulated. Following this, 'public' as a category is problematized where various versions of 'public' are created in the provision of the sanitation facilities and how the state as well as the public regard them as a version of 'public'. In the execution of these sanitation plans and the existent governance pattern, the analysis will extend into an understanding of how the above results in sustaining the health of a particular version of the public and neglects other versions. Thus, sustenance of public health is also problematized along with that of the 'public' (as a category). With focus on the governance of the city, the paper also deals with an analysis of the negotiations of the public with the state and 'publics' themselves. There is an attempt to capture the dynamics evident between the state and the public and within the various versions of the 'public' that is contained and is emblematic in the spatiality.

The aim of the analysis of the "exceptional" governance pattern and planning of Gurugram through sanitation is to understand and contest the uniqueness of Gurugram as a space containing the above dynamics as well as its popularised marketed characteristics of being a model city.

\section{The emergence of Gurugram}

Those of us who know Delhi and even those who come here for the first time cannot but be struck by the fact that all is not well with the capital city. Matters have really come to a head. There are all-round dis-comfort and discontent. Traffic jams and accidents, sprawling colonies-without the vital conveniences of life in the matter of sanitation, overcrowding everywhere and particularly in miserable slum areas, miles of ribbon developed hut-shops, 
chronic water-shortage, all add to the distress which is bad at any time but is well highly intolerable during the rainy season'. (MoH, 2017) The dilapidated condition of Delhi in the 1950s-60s which aggravated over the next two decades, finally led to the formalisation of the idea for the expansion of Delhi through the NCR Planning Board in 1985. The Regional Plan of 2001, formulated by the board, mainly focussed on deflecting the population from the capital via a multi-nodal regional growth pattern such that the health conditions of people are secured with the provision of facilities like sanitation. One of the centres of this expansion was Gurugram which was already experiencing inflow of migrants since the coming of Maruti Automobile manufacturing unit in the 1980s in the city due to its close proximity to Delhi. Similarly, the initial private investments made by developers such as Delhi Land and Finance (DLF) were all based on the proximity to the metropolis. However, gradually, the high dependence of the millennial city on Delhi is seen to be declining today. As pointed out by (Denis, Mukhopadhyay, \& Zérah, 2012), Gurugram is one of the closest example to subaltern urbanisation where despite the city's dependence on the metropolis for educated labour, connectivity to other cities through roadways, metro, the dissimilarity in the population growth of the two cities cannot be ignored-5.7 per cent in Gurugram as compared to 1.9 per cent in Delhi in the past decade. Apart from this, the increase in the density of service sector offices along $\mathrm{NH}-8$, expansion of the city and incorporation of Manesar area, increase in the municipality area and coming up of multiple bodies for the purpose of governance, point to the growing autonomy of the millennial city. (Denis et al., 2012)

Gurugram is often popularly regarded as the private city where developmental works and planning are guided by private players. Gururani remarks the presence of flexible planning, where public works is transferred from the state to the private agencies in the city (Gururani, 2015). Is the city and its planning and governance privatised to the extent that the state's presence is nominal? The city has numerous state bodies involved in planning and governance namely, GMDA (Gurugram Metropolitan Development Authority), HUDA (Haryana Urban Development Authority), and MCG (Municipal Corporation of Gurugram). However, these government bodies involve private agencies in their functioning, for example: sectors are given to private developers like ANSALS, DLF for developing them from scratch and for maintenance. This kind of planning and governance in the city is seen to add exclusivity to the city as popular and has also created chaos.

The paper attempts to understand this exclusivity of the millennial city and will analyse the involvement and non-involvement of the state in the governance and planning of the city. It will, hence, discuss the dynamics between the state and the public by examining the versions of publics created in the process. The exploration will specifically focus on the provision of sanitation infrastructure in the HUDA planned Sector 15 part 2. This sector is the closest settlement to $\mathrm{NH}-8$, has a Google office, hotels and a shopping mall on the outskirts and has a wide range of dwellers settled within in plot houses, group housing structures and scattered jhuggis. In studying the ways in which different kinds of settlements are linked to the provision of sanitation facilities, the paper examines how different notions of the public are 
constructed, defended and contested. The following sections will elaborateon the same with a discussion of firstly, how are sanitation facilities planned for and what is assured through the provision of the facility? Secondly, it will elaborate on who is the public that is being provided with the facility and what is the rationale behind it? Thirdly, how are negotiations carried between the public and state around the provision and non-provision of the facility?

\section{Sanitation facilities- what and who is secured?}

Like the Chadwick report published for 19th century Britain to cope with and prevent Cholera outbreaks in the future, the Interim Plan for Greater Delhi (on which the regional plans are based) also focussed on urban planning with a special focus on sanitation to secure the health conditions of the public. Sanitation facilities, especially connectivity and access to sewerage lines, are often considered as ways to prevent diseases and sustaining public health by controlling and mitigating risks. In the context of Gurugram, the sanitation plans are integrated with the land use plan. However, the question arises whether public health is regarded as a base on which sanitation plans are formulated and thereby executed. The paper argues on similar lines on whether the idea of public health is a centric latent base of the sanitation plan for Sector 15 part 2.

The analysis extends to understanding the public which is being provided with the sanitation facilities. The planning and installation of the main sewerage line was carried out by HUDA while the present connection of the house sewer lines with the main sewerage lines are done by MCG. MCG is also the executive agency maintaining the sewerage line and interacting with the public for grievance redressal. However, MCG delegates the tasks of maintenance and installation like cleaning of sewers, connecting household pipelines to various private agencies. The paper, while focussing on the governance pattern in the sector will delve into understanding the public being governed. Nikhil Anand's conception of public, which is plural and is situated in materiality, is used here to explore the different versions of public created. The point of view of the state (planners, the executive along with the private players being delegated tasks by the state) and that of the public in categorising and understanding the public would be considered. Thus, it would be examined whether the state is providing the public with the infrastructure on the basis of desirability and what happens to the section of the public who are not provided with sanitation facilities but are occupying the space. Following this, a conception of the 'public' as the public would be highlighted where the dynamics of the 'public' with the public would be explored. Under this, the conception of the public occupying different spaces like plot house and jhuggis will be considered along with the provision of sanitation facility. This will help us develop an understanding of how sustenance of public health, through the provision of sanitation facilities, is also differential in nature where public health of one version of the publics is sustained while the other is neglected.

The above will be telling of the governance of the state through categorisation of the public and provision of sanitary facilities, and how their dynamics is emblematic on the space. However, the dynamics and form of governance would be understood holistically with an 
analysis of the agency of the public in terms of how actively they negotiate with the state and with themselves. The following section discusses the same.

\section{Negotiations of the public}

The understanding of the public should be intertwined with the concept of citizenship when active negotiations are considered. Citizenship (Das \& Randeria, 2015) here, has two aspects: one which is given by the state for being the citizens of the country and the other through the claims that the public make on the state, for instance, in availing the sanitation facilities. In terms of provision of facility like sewer connection, the sector experiences a dynamic between the state and the public as well as the 'public' and the public where the different versions of public exploiting their citizenship rights become precarious i.e. specific to space and time. This is reflected in the negotiation process of the public with the state, which are of two kinds: one, when the public(s) is/are claiming to avail the sanitation facility from the state; and two, when the public(s) is/are withdrawing their claim for the same. In the first condition, the public who are not provided with the facility actively engages with the state to avail it and reaffirm their rights. There is also an attempt to theorise the practices of the various publics when the state is not providing facilities; here sanitation facility and the state's response to these practices. Whereas, in the second case, the public withdraw their claims and refuse to exploit their rights as citizens. The second case becomes interesting to examine as the reasons behind resorting to such practices differs across publics and is varied in nature-from being dissatisfied with the services of the state to resisting from the revelation of the identity or area of settlement. The paper tries to explore these conditions of negotiations and the state's active and inactive responses in each case.

Additionally, the paper explores the negotiations among different publics and how one version of the 'public' claiming their rights for sanitation facility from the state regard the version who are not claiming their rights for the same. Here, the analysis would focus on the dynamics between the plot house holders of the sector and the public settled in the jhuggis within the sector. The two strands of discussion, here, will reveal the versions of the 'public' created in the course of negotiations as well as governance over life in the various cases described above.

\section{The 'exclusivity' of the millennial city}

Gurugram's governance and planning through the case study of Sector 15 part 2 can be used to examine its exclusivity and the nature of its popular characteristics like having flexible planning, being a private city, the benign nature of the state and whether it is present in other cities of India as well. 


\section{References}

Anand, N. (2016). Hydraulic publics. Limn (7), 1-6. Retrieved from https://limn.it/articles/hydraulic-publics/

Das, V., \& Randeria, S. (2015). Politics of the urban poor: Aesthetics, ethics, volatility, precarity. Current Anthropology, 56(11), 3-14. https://doi.org/10.1086/682353

Doshi, V. (2016, July 4). Gurgaon: What life is like in the Indian city built by private companies. The Guardian. Retrieved from https://www.theguardian.com/sustainablebusiness/2016/jul/04/gurgaon-life-city-built-private-companies-india-intel-google

Gururani, S., \& Kose, B. (2015). Shifting terrain: Questions of governance in India's cities and their peripheries. In P. Hamel \& R. Keil (Eds.), Suburban governance: A global view (pp. 278302). Toronto, ON: University of Toronto Press.

Denis, E., Mukhopadhyay, P., \& Zérah, M.-H. (2012). Subaltern urbanisation in India. Economic and Political Weekly, 47(30), 52-62.

FAO. (2013). The State of Food and Agriculture. Rome.

Ministry of Health. (2017). Interim general plan for greater Delhi. Retrieved from http://ncrpb.nic.in/pdf_files/Interim\%20General\%20Plan\%20for\%20Greater\%20Delhi.PD $\mathrm{F}$ 



\section{Exploring identity and space through the study of housing rental market in Delhi}

Asaf Ali Lone; Centre for Public Interest Law, Jindal Global Law School

A story that became a common trope during my fieldwork while talking to brokers in Munirka who are mostly Jats was about how Munirka is being overtaken by people from Northeast or 'Manipuris'. A common trait in this story was the street inside Munirka village known by many names by the residents. But the name 'airport' was the most sensational one for brokers of all the names. The Jat brokers used to say they (people from Northeast or Manipuris) have named this chowk as 'airport' putting an emphasis on the changing nature of the space. How they are overcrowding the place and occupying it with their presence which means an overt presence of them. It is interesting to note at the same time 'airport' which is known as the Babulal Chowk otherwise, has most of the tenants from northeast living there. The street starts from Anupam restaurant located towards the Palam Flyover side and ends inside the Munirka Village at Babu Lal Chowk has most of the shops and buildings rented by the Northeastern community. The Jat brokers signified at the same time a loss of connection with the space where people from Northeast have established themselves inside the village.

Munirka is an urban village and it has a sprawling flow of tenants across the village from various regions of the country. On its one side, it is very close to Jawharlal Nehru University and on the other hand it is easily connected to various parts of the city and Gurgaon also. And with Metro extending through this area the dynamics would be changing more. The most interesting part of the story was when the brokers were asked why they named it as 'airport'. Most of them said we don't know and they (Manipuris) named it because they straightaway come from Northeast and stay here with their relatives and friends. During the conversations with tenants who were from Northeast in the street spread from Anupam restaurant and Babu Lal Chowk. There were different narratives that one got to hear from them. One of the narratives was that in the initial years when people from Northeast started living in Munirka. The Babulal Chowk during the monsoon season used to overflow with the sewage of the drains. There were human feces and sewage littered around the chowk. So they used to call it 'Ak-pot' which in their local lingua signified a place filled with shit or sewage. And the local Jat community couldn't understand this word and they misunderstood it as 'airport' not 'Ak-pot'. Other narrative was that when a person from northeast arrives in Delhi, they are asked to drop at Anupam restaurant which is situated towards the Palam flyover road. From there they are told to walk straight to the street till Babu Lal Chowk. The street till Babu Lal Chowk is very narrow and it suddenly opens up at Babu Lal chowk making the space more open, spacious and airy. Then from here they are picked up by their friends and relatives and taken to their rooms. So this place signified an 'airport' for them. 
The different narratives tell us how a small street becomes a contested space as the population migrates into a city. How a name in itself brings with itself different narratives of imagining a space with the narrative of belongingness with the city and a sense of loss with their region. At the same time, it becomes a story for the Jat community losing of their culture, control and assertion on the space. In this story, lies the history of their migration, conflict, violence and differences which at the same time emerge as they associate themselves with the city by creating a space of their own which they call as 'home'. The narratives in itself brings in different dynamics of housing and living in a city for those who have migrated from other regions especially from Northeast and are settling in Delhi (McDuie-Ra, 2012).

During my fieldwork in Jamia Nagar, a Muslim concentrated space. Some even call it a 'Muslim ghetto' or a 'Muslim area'. But Jamia Nagar (Jamil, 2017) in itself is spatially very distinct and includes many mohalas, (Kirmani, 2013) localities and areas. Some of them are graded in terms of class, community and higher real estate values also when it comes to housing parameters. Like, Batla House and Abul Fazal two of the areas within Jamia Nagar where I conducted my fieldwork are in itself very diverse spaces. From slums to gated houses and colonies it's just like any other space in Delhi. Jamia Nagar has seen migration from the city and outside the city likewise. Mostly one will find people from UP and Bihar who have come from outside the city to settle here. Jamia Nagar again is one of the spaces which has a high housing demand for Muslims. The reasons being many, but identity and memories of violence have played a major role in the construction of Jamia as a residential space for Muslims. Within this 'homogenous' space, the diversities one finds replicate the differences across caste, community and class orders and obliterates the homogeneity of the space as a unit. There are narratives where owners refuse housing to people from Western U.P. because of the fear of the 'qabza' or them being 'rude' people. The Bihari identity plays itself very differently than a person belonging to U.P. Then those who belong to Old Delhi have their own linkages and associations with the city. These tropes of identity play differently with their sense of belonging to Jamia Nagar and to the city of Delhi.

The construction of an 'other' becomes a confluence of gender, caste, community and regional associations with one's social, cultural and religious identities thus creating a distinct socio-geographical space which gets marked both on the body and space inhabited by the 'other'. This other is thus distanced as the spaces they inhabit and in a way the process of segregation from the mainstream of the city creates a different dynamic in the living realities of these people. Thus, not only separating them in their day-to-day lives but creating and sustaining prejudices and biases that enters into the logics of housing market also. In this paper, I want to approach it through the study of rental housing in Delhi based on the field research conducted in Munirka and Jamia Nagar. ${ }^{1}$ 
The huge population that flows into major cities of India gets spread across the city as various factors work out that primarily facilitate housing to these people who travel from other regions into the cities. Rental housing in particular provides an entry into the city for people migrating from other regions into cities. In this paper, I argue how rental housing market is deeply embedded within the social, economic, cultural and community structures. How it plays a role in facilitating and accommodating people not only from other regions but within the city itself. The rental housing can also act as a deterrent towards creating an inclusive, affordable, adaptive and equitable city as it can perpetuate discriminations and act as a catalyst also for various forms of segregations in the city.

In this paper, I will try to chart out various factors, modalities and mechanisms within rental housing market that play a role in settling of the people coming to cities particularly taking a case study of Jamia Nagar and Munirka in Delhi. How people navigate into a city not known to them with respect to how rental market operates in these two sites. Within the larger frame of how rental housing market works in Delhi this paper will try to explore how identity and space plays a role in creating spaces that becomes associated with certain markers of a particular community facilitating both inclusion and exclusion from a space. (Susewind, 2015; Gayer 2012) Thus, how it facilitates or denies coming of certain tenants to that area. It will also explore how the division of a city into various spaces like ghettos, slums, gated colonies and gentrified housing societies impacts the access to housing. Not only affordable housing and housing to all, a dignified and respectable housing is a much needed requirement for a lot of people who can't afford to live without being stigmatized in the cities. But at the same time recognizing the caste, community and religious differences which becomes a larger hindrance not only to housing at a basic level but creates issues and problems at multiples levels which leads to segregation in the cities and discriminations and prejudices in the rental housing. Thus, the discrimination in rental housing is intrinsically related to various biases and prejudices that help in constructing the narratives of othering the other as these biases and prejudices penetrate deep into the logics of housing market also.

Various newspaper reports and studies have pointed to the discrimination and prejudices in rental housing markets faced by Dalits and Muslims in particular. (Thorat, Banerjee, Mishra, \& Rizvi, 2015; Datta \& Pathania, 2016). The access to rental market is facilitated by various factors. In areas like Jamia Nagar and Munirka social and personal networks plays a major role in facilitating access to the rental spaces. One of the reasons the reliance on social networks is because of the existing biases, prejudices that has become a part of the struggles of looking for a house in a city like Delhi. Thus, personal or social networks play an important role in facilitating access to rental housing. It's very important to understand the nature of rental housing and housing market in order to understand how access is created within different areas of a city. In Munirka, where brokers are predominantly Jats and have prejudices and biases with tenants migrating from Northeast region. But at the same time, they have not been able to stop the inflow of tenants from Northeast region into Munirka. 
The paper will further explore how in Munirka brokers facilitate a role in rental housing market. How inspite of various prejudices and biases tenants are able to access rental housing market.

In Jamia Nagar as it's a Muslim concentrated area mostly Muslims who have settled here are particularly from Bihar and UP. The people coming from the villages or towns from these locations will at the first instance talk to those people who they know and have settled there. Majorly the rental housing works on jaan pehchaan. The brokers also facilitate the access to the houses in the area but due to the history of the place, the dynamics works out in different ways. The paper will look at different dynamics that facilitate routes of access of rental housing in the area.

This paper will look at the intersection of identity and marginality and try to understand the nature of space and rental housing market to evolve the dynamics of the segregation in the city that operate at multiple-levels.

\section{Endnote}

The field research was conducted as part of the research for the Housing Discrimination Project

\section{References}

Datta, S. \& V. Pathania (2016). For whom the phone does (not) ring? Discrimination in the rental housing market in Delhi (2016/55). Helsinki: UNU-WIDER.

Gayer, L. (2012). Safe and sound: Searching for a "good environment". In L. Gayer \& C. Jaffrelot, (Ed.), Muslims in Indian cities: Trajectories of marginalisation (pp. 213-236). London: Hurst \& Company.

Jamil, G. (2017). Accumulation by segregation: Muslim localities in Delhi. New Delhi: Oxford University Press.

Kirmani, N. (2013). Questioning the muslim woman: Identity and insecurity in an urban Indian locality. New Delhi, India: Routledge.

McDuie-Ra, D. (2012). Northeast migrants in Delhi: Race, refuge and retail. Amsterdam: Amsterdam University Press.

Susewind, R. (2015). Spatial segregation, real estate markets and the political economy of corruption in Lucknow, India. Journal of South Asian Development, 10(3), 267-291.

Thorat, S., Banerjee, A., Mishra, V. K., \& Rizvi, F. (2015). Urban rental housing market. Economic \& Political Weekly, 50(27), 47-53. 


\section{Fear, activism and formation of counter-urban consciousness: Experiencing Delhi from the margins, a case of Kathputli Colony}

Rajorshi Chowdhary; Jawaharlal Nehru University

This proposed article will attempt to probe into the nature of the relationship between urban fear, activism and the development of a counter-urban consciousness, among the poor and marginalised, in the city of Delhi, through an illustration of a colony marked for redevelopment: the Kathputli colony.

The research is expected to proceed along two, mutually informed ways viz. a contextual reading of literature available on urban fear, contentious politics, Kathputli colony and the nature of activism surrounding the re-development project, which offers much needed context and background, eventually leading up to interactions on the field with individuals and communities. In terms of primary research, the work will draw from interviews and discussions with civil rights groups working in Delhi (activists), members of the urban redevelopment council such as the Delhi Urban Shelter Improvement Board (DUSIB), Delhi Development Authority (DDA, agents of the state) and also, the population who are evicted through urban policies (marginalised).

This research assumes importance because in the present context, the world over, one can easily see the nature of public spaces being re-defined, and nowhere is this more apparent than in the case of cities. While it is largely in the urban spaces that notions of public, civility, and community are negotiated, it is in the very same geography that such ideals are facing unprecedented levels of assault, with questions being posed over their meaning. Nowhere is it more pronounced than in the city of Delhi, which stands as a glaring reminder of the inequality that infests 21 st century society, 21 st century India.

The proposed paper firstly, contends that fear must be understood beyond the terms as espoused by vulnerability to crime and violence as in being physically attacked in the city, which is often advertised. Not discounting the importance of crime and violence, the proposed paper maintains that fear must be seen as an existential state of being for a large section of the population who inhabit the liminal spaces of the city. For instance, as is the case with the larger urban population of Delhi, fear has almost become synonymous to being in the city. As per the data released by the National Crime Records Bureau (NCRB), Delhi has 182.1 violent crimes committed per 100,000 persons as opposed to the national average of 77.2 for 100,000 persons (NCRB, 2017). Not only does this make the city unsafe, but add to it the reputation of being hostile and unsavoury towards women (Satija and Datta, 2015). That such numbers are disturbing is unquestionable. However, one needs to look beyond the immediate impact of figures to assess the deeper intrusion of fear into the social fabric. A case in point is the Kathputli colony, where residents have not only been evicted from their homes, but have also been subject to repeated violence by the organs of the state: most 
notably, the police (Nagpal, 2017). These acts do not feature as either 'crime' or 'violence' in the everyday lexicon, but end up generating a deep rooted sense of anxiety which graduates into pervasive fear of both the state and its organs. However, this is a moment that has far greater implications for defining the relation of the self vis-a-vis the city for the populations in question. The rest of the proposed paper will try to explicate this relationship with greater clarity.

To this effect, in the second section, this paper will argue that pervasive fear generates a transcendental experience, that instead of reducing the populations to the status of victims, it bestows them with a will to action. In other words, fear, as opposed to robbing the populations of agency, in fact serves to bestow a sense of purpose which in practicable terms gets translated into concerted, anti-hegemonic and anti-authoritarian politics from below, understood elsewhere as 'contentious politics' (Tilly, 2008; Tarrow, 2012; Tilly and Tarrow, 2015).

It is to say therefore, that while fear remains, in many cases, the primary emotive reference, the same does not equate to being numbed by the emotion i.e. the primacy of fear in everyday lives leads to a case of rallying around in terms of continuing to agitate against the state in innovative ways. While the Kathputli colony residents may be subject to the very real fear of losing their homes, their jobs and their livelihoods, it has not stopped them from forming groups to display their contributions to the larger society and earmark their importance to the city of Delhi (Abraham, 2017).

The Bhule Bisre Kalakaar Sehkari Samiti (Society for the Forgotten Artists) and the Kalakaar (Artists) Trust, respectively stand testament to the activism that is visibly part of the social fabric, despite the pervasiveness of fear. The former pledges to publicise the artistry of the residents of the colony, while the latter seeks to offer education in the form of schooling. This goes to show that activism does not die down on the face of fear, but rather evolves to carve out alternate geographies of hope within the communities affected (Banda, Vaidya and Adler, 2013; Dubey, 2016).

Thirdly, the paper will argue that this activism, gestating in the atmosphere of pervasive fear has potential for the formation of a counter-urban consciousness. For the purposes of this study, counter urban-consciousness may be defined as the sense of being part of a larger urban community which while limited in terms of immediately influencing urban policy, nonetheless possesses the capacity to significantly shape urban practices and the idea of being-in-the city in the long run.

Copious amounts of literature is available on how the increasingly self-assured middle-classes project their identity as belonging to the city; the prolonged periods of activism have the potential to do the same for the marginalised and the disenfranchised. In other words, articulations in the form of processions, dharnas, sit-ins, demonstrations and rallies have the 
possibility to take back space and more importantly, reframe the meaning of what it means to be a citizen of the city.

It is pertinent to mention that the activism of the middle-classes viewed here as the group of people who project economic stability, social progress and political transparency, garners both national as well as international press; the activism of the disenfranchised is deemed a nuisance to 'public order', and deserving to be removed. Agitation in this case has to do with the claim by the former, to belong in the urban spaces, unlike the activism that seeks to define the nature and scope of the urban spaces, in case of the latter. In other words, here we have an activism that is characterised by a low-key defensive nature, as opposed to the more assertive interpretations by the empowered group. This uses the concept of 'quiet encroachment' as propounded by Asef Bayat, whereas with resources, activism too is not especially aggrandised, but its ideas and principles slowly gain traction within the larger urban community_again, those who are the most vulnerable in the city (Bayat, 2000).

Fourthly, the defensive nature of this type of activism, again does not rob it of any sense of agency, in terms of shaping the eventual meaning of urban activism, but on the contrary may offer more creative interpretations of what it means to negotiate with the state. To cite an example, as has been highlighted, so far it has been the middle-classes who have mixed elements of activism with juridical intervention, to sway public opinion (it must be made clear here that the judiciary too, has taken up a more proactive role, vis-a-vis the regulation of public spaces), Public Interest Litigations (PILs) being the most glaring of instruments.

On the other end of the spectrum, through sustained periods of agitations and contentionsincorporating the various civil rights groups, urban activists and even workers and students' unions-time and again, resistance has been articulated to the logic that has cornered the meaning of activism as a parochial instrument in the hands of a select few, to push cynical agendas forward.

For instance, in many of the PILs submitted to the courts, the petitioners, mentioned their rights as being the citizens of the city of Delhi, the petitions filed for instance, on behalf of the slum dwellers, saw the articulation of citizenship not as restricted to a city, but drew attention to citizenship rights as extending throughout the country (Bhan, 2014: 551). In other words, the very same juridical logic that was used to disenfranchise the poor is now inverted, to make a case for the marginalised to stake their claims to the city as equals.

Finally, the paper will conclude by looking at the city of Delhi: the neighbourhood of Kathputli colony, in particular- to understand whether a counter-urban consciousness has indeed been forged as a result of the activism borne out of the moment when the emotive reference changes from a general feeling of insecurity to that of tangible fear. The findings from this particular case, can then be used to bring into dialogue, the current scholarship on citizenship, rights and claims specific to urban spaces and potentially chart newer trajectories 
for developing an urban studies field that is at once rooted in local knowledge but simultaneously applicable at regional, national or even global levels, if so required.

Keywords: Fear; Activism; Urban Consciousness; Contentious Politics; Citizenship; Marginalised; Delhi

References: (* indicates a primary source)

Abraham, N. (2017, June 13). We are not gangsters we are artists: Can Delhi's Kathputli colony survive land sharks? Scroll.in. Retrieved from https://scroll.in/magazine/834483/we-arenot-gangsters-we-are-artists-can-delhis-kathputli-colony-survive-land-sharks

Banda, S., Vaidya, Y., \& Adler, D. (2013). The case of Kathputli Colony: Mapping Delhi's first in-situ slum rehabilitation project (CPR Working Paper No. 3). New Delhi: Centre for Policy Research.

Bayat, A. (2000). From 'dangerous classes' to 'quiet rebels': Politics of the urban subaltern in the global south. International Sociology, 15(3), 533-557. https://doi.org/10.1177/026858000015003005

Bhan, G. (2009). This is no longer the city I once knew: Evictions, the urban poor and the right to the city in millennial Delhi. Environment and Urbanization, 21(1), 127-142. https://doi.org/10.1177/0956247809103009

Bhan, G. (2014). The impoverishment of poverty: Reflections on urban citizenship and inequality in contemporary Delhi. Environment and Urbanization, 26(2), 547-560. https://doi.org/10.1177/0956247814542391

Dey, A. (2016, December 21). With demolition at the door of Delhi's colony of puppeteers, 300 policemen keep watch. Scroll.in. Retrieved from https://scroll.in/article/824627/withdemolition-at-the-door-of-delhis-colony-of-puppeteers-300-policemen-keep-watch

Dubey, S. (2016). Understanding participation in a heterogeneous community: The resettlement of Kathputli Colony. In S. Chakravarty \& R. Negi (Eds.), Space, planning and everyday contestations in Delhi (pp. 35-56), New Delhi, India: Springer.

Dupont, V. D. (2011). The dream of Delhi as a global city. International Journal of Urban and Regional Research, 35(3), 533-554. https://doi.org/10.1111/j.1468-2427.2010.01027.x.

Dupont, V., Banda, S., Vaidya, Y., \& Gowda, M. S. (2014). Unpacking participation in Kathputli Colony. Economic \& Political Weekly, 49(24), 39-47.

Ghertner, D. A. (2011). Gentrifying the state, gentrifying participation: Elite governance programs in Delhi. International Journal of Urban and Regional Research, 35(3), 504-532. https://doi.org/10.1111/j.1468-2427.2011.01043.x

Ghertner, D, A. (2013). Gentrifying the state: Governance, participation and the rise of middleclass power in Delhi. In G. Shatkin, (Ed.), Contesting the Indian city: global visions and the politics of the local (pp. 176-207). Chichester, West Sussex: Wiley Blackwell.

National Crime Records Bureau. (2017). Crime in India 2016: Statistics. New Delhi, India: National Crime Records Bureau.

Nagpal, A. (2017, November 01). Uprooted lives: Delhi's Kathputli Colony residents watched their homes razed to the ground. The Wire. Retrieved from https://thewire.in/government/delhi-kathputli-colony-demolition 
Satija, S., \& Datta, A. (2015). Crime against women and children in Delhi: Analysis of secondary and empirical data. Economic \& Political Weekly, 50(9), 87-97.

Tarrow, S. (2012). Strangers at the gates: Movements and states in contentious politics. New York: Cambridge University Press.

Tilly, C. (2008). Contentious performances. New York: Cambridge University Press.

Tilly, C., \& Tarrow, S. (2015). Contentious politics (2nd ed.). New York: Oxford University Press. 


\section{Menus matter: Examining class and Bengali cuisine culture through restaurant menus in Kolkata}

Runa Das Chaudhuri; University of Calcutta

Bengali food, particularly in the domestic context has received much attention in recent academic scholarship, but there is relative scarcity of studies on cultures of public dining practices in restaurants. This paper attempts to address this gap by exploring how a burgeoning ethnic restaurant industry serving Bengali food in Kolkata conditions classinherited food practices. In this context, restaurant menu cards, I argue are emblematic of articulating differences and distinctions in matters of class and taste which socially mark the choice of a distinctive food moment and conditions the terms of fashioning a neo-ethnic global identity. Based on in-depth interviews of 46 respondents who assessed food entrées of restaurant menu cards, this paper examines the branding of a local cuisine and the moulding of a neo-ethnic 'global' identity accomplished by steeping tradition and authenticity in an aura of globality. Here, neo-ethnicity is to be understood as the stylised presentation of traditional cultures (of food) which are pitched at a level such that they may participate in a global order. It is a value nurtured in Bengali transnational imaginary to strive to claim the label of a worldclass cosmopolitanism for its own ethnic identity.

This paper predominantly presents perceptions of affluent upper-middle-class Bengalis and a few non- Bengali interlocutors in Kolkata concerning entrées of various Bengali restaurants' menu cards. It seeks to examine how these evaluations are often influenced by narratives of a loss of rootedness on the part of many Bengalis and a consequent reclamation of heritages in a cosmopolitan mode. The acts of eating out in Bengali restaurants, manifest an attitude of 'gastro-cosmopolitanism' practiced mostly by Bengalis who live or perceive to live their lives within the scope of a trans nation. Gastro-cosmopolitanism, I argue is an attitude which breeds an elite sensitivity, identifiably urban amongst consumers whose shared experience is based on a certain loss of rootedness and who wish to reclaim their roots in ways, stylishly traditional and not garishly ethnic.

The paper observes that while the global latitude in the culinary order has paved for blending of cultures evident in fusion cuisine, it has simultaneously reproduced the revalorisation of an ethnic cuisine as heritage, exotic and exclusive. The nouveau Bengali possesses a cosmopolitanism which is not at odds with a deep ethnocentricity nurtured in matters of sensibilities about the culture of the Bengali's place of origin. But the manner of appropriating one's culture, here of ethnic cuisine had to be steeped in a distinct mode such that it may cater to their tastes of globality. This perception of a fashionably ethnic Bengaliness is also subscribed by the local upper-middle-class Bengali population desiring to locate themselves in the transnational horizon. Further, class inflections in choosing from a diversity of multicultural food options reveal gustatory antinomies on the consumers' part eager to stake a global cosmopolitan identity while keeping their collateral attempts to align to a lost past alive in imagination. 


\section{The Background}

Gourmandising has always been a marker of Bengaliness. But the valorisation of a regional cuisine in cultivating preferences for ethnic food in upmarket Bengali restaurants is a significant trend entailing scrutiny especially in an age when food has become more subject to social needs of fashion. This nurturing of a 'taste of luxury' reflects the commercial aestheticisation of a cuisine; it is also characteristically linked to the Bengali world citizen's staking cosmopolitanism and choosing a transnationally competent habitus. Subscribing to Pierre Bourdieu's axiom which states 'taste classifies and...classifies the classifier,' (Bourdieu 1984:6) I argue that the burgeoning fascination for one's regional cuisine renders legitimacy to its consumption in public gastro-destinations in restaurants; it further classes its consumer as one of the transnational universe. The impact of global foodways of the West on the cooking practices in middle-class households in Calcutta in India's immediate post-liberalisation period has attracted scholarly attention (Donner 2008: 155-56). While the culture of dining out to taste others' cuisines in restaurants also thrived in this period, the retention of ethnic identity did count remaining cogently tied to 'home-made meals' (Ibid: 157). Post 2000s, the increasing trend of enjoying home-like food in a fresh breed of Bengali restaurants suggests a displacement of the hearth to the restaurant kitchen, especially for people on the move. This paper examines the perceptions upper-middle-class affluent Bengalis deliberated on restaurant menu entrées of their ethnic cuisine with an aim to understand their ways of cultivating distinctive tastes in the arena of fine dining. To this end, it seeks to scrutinise the prevalent discourses produced at the crossroads of taste, class and dining in Bengali restaurants.

\section{Review of literature}

Recent scholarship on Bengali cuisine has focussed on historiographic accounts of what constituted authentic food and cooking in colonial times (Ray 2015); how food and cuisine represented a vibrant site on which a complex rhetorical struggle between colonialism and nationalism was played out (Sengupta 2010); and how the bhadralok Bengali middle class constructed a 'doxa' of gastronomy in the late colonial period to claim a cultural exclusivity for itself (Prasad 2006). Specific influences on Bengali cuisine for instance, by the Tagore family have been explored to demonstrate how Tagore's use of gastronomic tropes was at odds with his theory of internationalism (Roy 2012) while the particular politics of street food in the city has also been examined (Bhattacharya 2004). Other studies illuminate how gastronomy in the diaspora is teased out through nostalgic, sometimes bordering on orientalist evocations of a past and place (Roy 2010) or ways in which Bengali-American immigrants use their cuisine as anchors to grapple with the grave and immediate problem of defining themselves in their home away from home (Ray 2004). While the evolution of a cuisine in colonial Bengal and its location vis-a-vis narratives of domesticity/colonialism/nationalism/internationalism or the gastro-poetics of the diaspora have been studied, scarce attention has been paid to the branding of an ethnic regional cuisine in its own land. Bengali restaurants too, it has been 
argued, nurture a kind of domesticity offering a home-like familial poribesh ${ }^{1}$ (Janeja 2013: 128) serving traditional 'normal' food. But while concerns on tastes, consumption and class identifications have been raised in scholarship on food cultures, there have been barring studies on street food, which mostly address home cooking ${ }^{2}$ in the domestic context. This can partially be explained by the fact that the consumption of Bengali food is usually restricted to the realm of home-cooked food. 'When it comes to eating outside the home in a restaurant', Ashish Nandy writing in 2004 noted, 'Bengalis tend to choose some version of Mughal, North Indian or, less frequently, European food' (Nandy 2004:14). It is true that the Bengali restaurant as a propitious setting for observing public ethnicity is a relatively recent phenomenon. A fresh crop of restaurants have spawned particularly those serving Bengali food in Kolkata in the past decade and a half pushing the envelope when it comes to the way the urban folk are eating, what they are eating and how they are eating. In fact, public gastrodestinations in Bengali restaurants are emerging as dynamic sites of consumption unfolding intense mediations on structures of class and choice for a growing clientele. This is reflected in food guides which nowadays publish separate entries as well as ratings of Bengali restaurants. In 2013, Times Food Guide for instance, rated Aaheli, Bohemian, Kasturi, Kewpies and Oh! Calcutta as the best Bengali restaurants of the city.

\section{Methodology}

Forty-six in-depth interviews including those of 28 men and 18 women (between 35-69 years of age) were conducted in two phases stretching over 16 months in 2017-18. Interviewees included the author's own acquaintances and eventually following a snowballing method, ${ }^{3}$ drew upon respondents belonging to affluent upper-middle-class Bengali families, ${ }^{4}$ many of which had at least one member residing outside the city and some non-Bengali families which had shared strong filial bonds with residents of the city.

Of the 46 respondents, 19 were non-Bengalis including 8 Punjabis, 5 Biharis, 4 Assamese and 2 Bangaloreans. Of the 27 Bengalis, 9 were non-residents, 5 were itinerant travellers and the rest were residents. Among the 27 Bengali respondents, 9 were females and the remaining 18 were males. The interviews conducted stretched between 70-90 minutes with a few extending over two hours. An identical packet of ten anonymised and numbered restaurant menu cards ${ }^{5}$ and two menu charts of pice hotels ${ }^{6}$ representing a cross-sampling of restaurants by class were given to each respondent. A coding worksheet was also provided to each respondent to facilitate the analysis of menus on dimensions including recipes, prices, vocabulary, and style of presentation. To elicit the diverse narratives of the shared cultural imaginary which surrounds and also arises out of frequent food trips to restaurants, interviewees were encouraged to share their perceptions, memories, emotions and experiences that they associated with Bengali cuisine and specifically comment on the ambience of the restaurant sites. 


\section{Findings}

In the present study, interview respondents identified higher-than-average prices, the presence of bar menus, fusion cuisine or specialised gourmet of yesteryears in high-end restaurants. Study findings primarily indicated that menu prices and the showcasing of cultural emblems could be used with fair reliability as an indicator of the class association of the restaurants. Low prices and simplicity of presentation of menu entrées, especially those which appeared unpretentious, at-your-face, basic, non-descriptive, easily identifiable by their names led respondents to identify them as ordinary. Respondents readily coded pice hotel menu charts characterised by their cheap cost, affordability and poor presentation. Thus stratification on the menu does exist.

The inclusion of lost traditional recipes and their exoticisation in Bengali restaurants' menu cards articulates their marketability. For instance, a recipe like Goalander Murgi famed to be a stew cooked in the steamer in Goalondo in erstwhile pre-partition east Bengal (now Bangladesh) today finds place in the menu card of Kewpies. In this way, when local histories survive through cultural artefacts like menu cards in a global world, become in an important sense globalised.

If restaurant food claims for itself a strong ethnic essentialism and a specific identity, it would have little room to manoeuvre in the business. So hybridisation of Bengali cuisine has been an unavoidable social process and chefs with a flair for innovation have been instrumental in adding new items to enhance what is understood as fine dining experience. It has been argued that the Bengali middle class in the post-independence era cultivated their cuisine as 'a liberal and cosmopolitan one in their attempts for homing in a capitalist economy' (Ray 2015:80). This entailed the incorporation of other flavours and their subsequent indigenisation. It was a kind of cosmopolitanism which involved an appreciation of the 'other', and of constructing a common space between separate spheres within which one 'moves'. In the global latitude however when cosmopolitanisms require us to ground 'our sense of mutuality and to learn to live in conditions of mutability' (Pollock et al. 2000), it is no longer only a question of appreciation or for that matter accommodation of different cultures. Rather cosmopolitanisms create a condition of creative bricolage (Calhoun 2003: 16), in this case of tastes producing what is to be understood as gastro-cosmopolitanism.

In fact, for Bengalis grazing as global citizens, the imagined pleasures of savouring home-like food in restaurants signifies that the kitchen is not dead; rather it is only undergoing cultural and nostalgic renovation. More important than the nostalgia however, is the role of the taster in redefining, appraising traditional food items. Surely, the status of traditional everyday Bengali cuisine gets projected as something much more avant garde when the taste is revisited by a native who has returned from abroad. The return of the native to the home land, real or imagined and to the native's own food, transforms its quotidian character. The food, once familiar undergoes a re-familiarisation as home-like food becomes available in the public realm of restaurants. In this encounter, the homeliness of food has to be convincingly 
persuasive to cater to tastes of nostalgia, memory and authenticity. Yet the menu items of Bengali restaurants convey more than these. Food entrées, both traditional and fusion, are presented in manners enticingly classist such that home food turns avant garde and fusion foods wear an exotic appeal. Often sprinkled with the spice of world-class cosmopolitanism, restaurant menu cards thus re-present ideal sites for classing the tastes of their honorary Bengali guests.

The discourse on the making of an emerging neo-ethnic global identity vis-a-vis food is problematised by dichotomies of traditional/global, homely/commercial, familiar/exotic, etc. The restaurant becomes 'an intensified and stylized presentation of social life in which the individual can pursue or execute a fantasy' (Finkelstein 1989: 14-15) - from the desire to purchase memorabilia in home-like food to the immersion in luxurious ethnicity in fusion food. In analysing diversities in the food template in Bengali restaurant menu cards, one fails to conclusively arrive at an ideal notion of gastro-cosmopolitanism because such an attempt is a fool's errand. This is the making of a neo-ethnic global identity which is not only influenced by people on the move, but is also equally affected by non-movers and advocates of Bengali food who decidedly are not too enthusiastic of fusion dishes but who reorganise their new experiences on food through the prism of class. For both movers and non-movers, the profiling of food is however never routed only through taste or only through class. Rather it is to be located at the intersectionality of taste vis-a-vis class, although not all to the same extent or in the same manner. So ideas of gastro-cosmopolitanism are scalar and classified for differentially placed Bengalis in the real or imagined transnational horizon.

\section{Endnotes}

${ }^{1}$ Poribesh in Bengali means ambience.

${ }^{2}$ In her work, Transactions in Tastes: The Collaborative Lives of Everyday Bengali Food, Manpreet Janeja has provided an elaborate analysis of eating out by Bengalis who wish to taste ghoroa ranna (homely cooking) or what constitutes a 'normal' authentic meal in Bengali restaurants.

${ }^{3}$ No data sets of diners or feedback forms were available at Bengali restaurants. So snowballing was used to collect data by locating information-rich key informants who had knowledge of potential subjects in their acquaintances.

${ }^{4}$ Of the 27 Bengalis interviewed, 5 stated an individual annual income ranging between 3.5 to 5 lakhs while the remaining 23 earned more than 5 lakhs. Of the 9 female respondents, 4 were housewives who stated an annual family income exceeding 7 lakhs.

${ }^{5}$ The 10 anonymised menu cards used in the present study included those of Oh! Calcutta, Kewpies, Bohemian, 6 Ballugunge Place, Aaheli, Saptapadi, Bhojohori Manna, Koshe Koha, Suruchi and Kasturi.

${ }^{6}$ Pice hotels deriving its name from paisa are commercially cheap hotels existing from colonial periods in urban Kolkata. Full meals are served here, each item is priced individually and menus are prepared on a daily basis according to availability of raw ingredients. 


\section{References}

Bourdieu, P. (1984). Distinction: A social critique of the judgement of taste. Cambridge, Massachusetts: Harvard University Press.

Calhoun, C. (2003). The elusive cosmopolitan ideal. Berkeley Journal of Sociology, 47, 3-26.

Donner, H. (2008). New vegetarianism: Food, gender and neo-liberal regimes in Bengali middle-class families. South Asia: Journal of South Asian Studies, 31(1), 143-169. https://doi.org/10.1080/00856400701874759

Finkelstein, J. (1989). Dining out: A sociology of modern manners. Dales Brewery: Polity Press. Janeja, M. (2013). Transactions in tastes: The collaborative lives of everyday Bengali food. New Delhi: Routledge.

Mukhopadhyay, B. (2004). Between elite hysteria and subaltern carnivalesque: The politics of street-food in the city of Calcutta. South Asia Research, 24(1), 37-50. https://doi.org/10.1177/0262728004042762

Nandy, A. (2004). The changing popular culture of Indian food: Preliminary notes. South Asia Research, 24(1), 9-19. https://doi.org/10.1177/0262728004042760

Prasad, S. (2006). Crisis, identity, and social distinction: Cultural politics of food, taste, and consumption in late colonial Bengal. Journal of Historical Sociology, 19(3), 245-265. https://doi.org/10.1111/j.1467-6443.2006.00281.x

Pollock, S., Bhabha, H. K., Breckenridge, C., \& Chakrabharty, D. (2000). Cosmopolitanisms. Public Culture, 12(3), 577-589. https://doi.org/10.1215/08992363-12-3-577

Ray, K. (2004). The migrant's table: Meals and memories in Bengali-American households. Philadelphia: Temple University Press.

Ray, U. (2015). Culinary culture in colonial India: A cosmopolitan platter and the middle class. Cambridge: Cambridge University Press.

Roy, P. (2010). Alimentary Tracts: Appetites, Aversions and the Postcolonial. London: Duke University Press.

Roy, S. (2012). On eating: Rabindranath Tagore's dis(h)courses. South Asia: Journal of South Asian Studies, 35(1), 33-47. https://doi.org/10.1080/00856401.2011.648901

Sengupta, J. (2010). Nation on a platter: The culture and politics of food and cuisine in colonial Bengal. Modern Asian Studies, 44(1), 81-98. https://doi.org/10.1017/S0026749X09990072

Wright, W., \& Ransom, E. (2005). Stratification on the menu: Using restaurant menus to examine social class. Teaching Sociology, 33(3), 310-316.

https://doi.org/10.1177/0092055X0503300311 


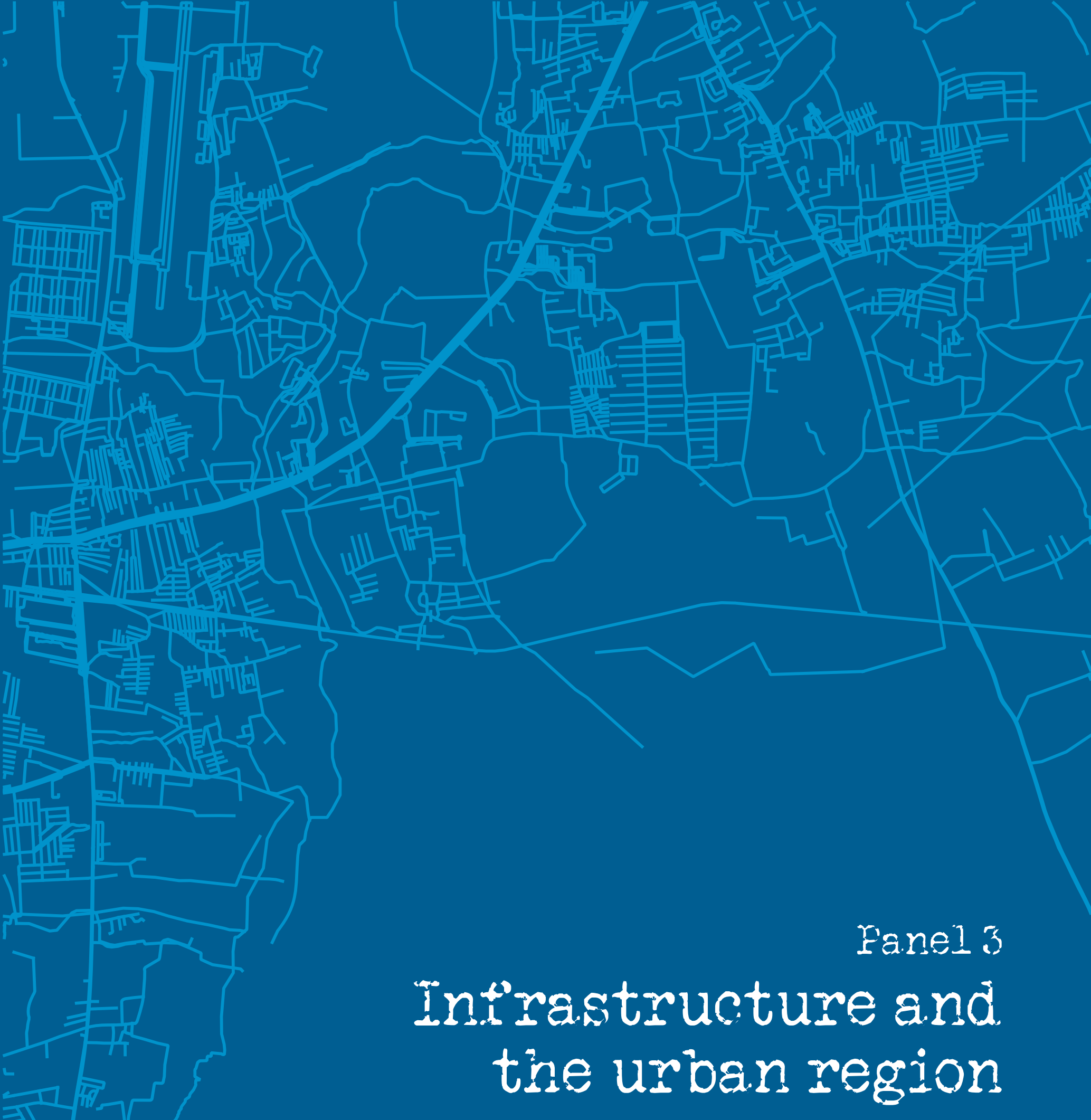




\section{Challenging inert flows between the city and the region: The canals and the brick kilns of Gurugram and Sonepat}

Pratik Mishra; Kings College London

This paper draws attention to that which is considered inert-objects that occupy significant space but often do not figure in the placemaking narratives of many residents around it. Urban drinking and wastewater canals and brick kilns located in peri-urban villages do not elicit any sharp commentary when you ask local village residents about them. Urban canals belong to the government and brick kilns to outside contractors; a frontier is drawn that marks them as disconnected enclaves. It can be argued that this is a discursive boundarydrawing rather than an actual one. Social and material processes intimately tie the canal and brick kiln to the lives and livelihoods of villagers. Their impact easily spills out of their material space and various intended and unintended flows are established between the village and the canal, or the village and the kiln. The discursive boundary-drawing reflects a lack of power over these spaces and could serve as a placemaking strategy that excludes outsiders from belonging to the village.

The objective is to challenge the 'inertness' of these understudied infrastructures and bring to light the social flows and processes that are otherwise ambiguated and overlooked. The central focus of this research is around the case of urban drinking and wastewater canals that flow through several villages on their path to the water treatment plant or after treatment in the sewage treatment plant; and ask how these infrastructures that serve the city's metabolism affect the lives and livelihoods of village residents, particularly farmers.

The investigation is placed within the recent infrastructural turn in human geography. There is growing interest in research around the social life of infrastructure where what is infrastructure or infrastructural is also increasingly acknowledged as a method or analytic over a static set of objects (Bjorkman, 2015). The scholarship that prises open the amalgamation of objects and relations within infrastructure is already established and is growing rapidly (Larkin, 2013). The paper thus takes infrastructure as an 'ethnographically graspable manifestation' (Rodgers \& O'Neill, 2012, p.401) opening it to the production of resources, power and meanings and observes how this plays out at the level of concrete everyday practice.

Drinking and wastewater canals are among the most understudied of the diverse sites of struggles around waterscapes in India. Their relatively small footprints and the lack of overt struggles excludes them from the larger waterscape debates, while the nature of canals as conduits or intermediaries between the points of extraction and the treatment plants, away from the interface of public delivery, precludes them from discussions on social reproduction and infrastructural violence. Their impact can, however, be highly profound in relation to the lives and agricultural livelihoods in villages where they flow through. The surface water that 
flows in the canal systems is open to seepage, groundwater recharge, illegal pumping of drinking water and wastewater irrigation. The structure of the canals in relation to the geographic conditions of land, social relations and technologies create differentiated risks and opportunities for farmers and produce complex distributional impacts that are unplanned and arbitrary. Empirical evidence in a previous research (Mishra and Narain, 2018) already reveals some of these processes in a village outside Gurugram that is extended, in the current research, over a larger area in Gurugram and Sonepat districts.

A secondary focus is to look at brick kilns in a similar light as the canals, conceptualising them also as urban infrastructures. An interest in brick kilns developed out of their high concentrations in the peri-urban villages of Khanda, Jharoth, and other villages outside Sonepat where the author was following the drinking water canals. Brick making complexes exist on the outskirts of the residential village area and are owned and managed by small outsider entrepreneurs (non-Haryanvi) as well as manned by migrant labourers. The brick complexes, however, are sustained by the material exchanges of soil, water and other resources through the village, as well as their labourers' stay in rented accommodation in the village. This research looks at how the materiality of the kilns as well as the presence of labourers working in the kilns produce new social forms within the villages and transform it.

This paper not only remedies the empirical neglect of these infrastructure, but also ties in to larger debates in urban theory by allowing us to view the city from its outside. The canals and the kilns constitute the village as the ecological hinterland to the city. The canals metabolise water and the kilns do the same for the soil, mostly in service to urban demands. This research takes an expanded process-oriented view of urbanisation and theorises the ecological hinterland of the city as one of the most active sites for production of the urban (Lefebvre, 1970). This is in line with urban political ecology's reading of the city as a process of flows (Merrifield, 1993; Sennet, 1996; Harvey, 1996).

The circulation of socially and physically metabolised nature is the relationship out of which the city is produced and reproduced; the entanglement of these flows with the villager's lifeworlds implicate them in this production. The mainstay of the author's ethnographic work is to reveal these entanglements-the concrete practices of accessing water from the canals, and the production of nature from the canals and kilns that is constituted by everyday practices - that is intended to draw attention to specific conjunctures shaping the lives and experiences of villagers (both locals and migrants).

Recent scholarship on planetary urbanisation, such as the work of Arboleda (2016) in Huasco Valley in Chile insists on understanding metabolic exchange as a planetary process which is no longer circumscribed by relations of physical proximity or juxtaposition. However, the literature on planetary urbanisation is still largely focussed on the flows of commodities and especially financial capital that travel at high speeds over long distances. Here, the 'heavy' materiality of water and bricks restrict their movements as they become uneconomical to 
transport over long distances. The city of Gurugram may consume resources from across the globe but is dependent upon its region for a steady supply of water and bricks. Looking at water and bricks, hence, allows us to look at the role of the region in the city's planetarisation. It also allows us to understand uneven urbanisation following Ibañez and Katsiskis' (2014) statement that the sclerotic and discontinuous fabrics of urbanisation exacerbate as global metabolic flows become more seamless.

The canals and the kilns are useful sites in drawing out relationships with the urban and rethinking the oft-used categories of marking subaltern spaces in relation to the urban. The categories I refer to here are the peri-urban, the periphery, and the hinterland. These three spatial descriptors for non-urban or subaltern spaces carry different connotations. The term 'peri-urban' generally carries an explicitly spatial connotation and is used predominantly in policy and empirical publications and only rarely in critical papers. 'Periphery' is a much more important term within critical literature and is a term with a long and complex genealogy. Periphery is a relational term and is always bound by its relation of 'otherness' to the centre. In relation to the urban, periphery always conveys an attachment, an aspiration to the city and its core identities. Hinterland is an explicitly metabolic category though its use within resource geographies tends to represent sites of resource extraction as well as dumping. The current focus on canals as constituting an ecological hinterland to the city is to suggest that the term 'hinterland' should subsume conduits of resource flow along with the source and sink within its consideration. The canals and the kilns can theoretically as well, be important to testing or reifying these spatial descriptors and giving new meaning to them.

\section{References}

Arboleda, M. (2016). In the nature of the non-city: Expanded infrastructural networks and the political ecology of planetary urbanisation. Antipode, 48(2), 233-251. https://doi.org/10.1111/anti.12175

Björkman, L. (2015). Infrastructure as method. In L. Björkman. Pipe politics, contested waters: Embedded infrastructures of millennial Mumbai. North Carolina, United Nations: Duke University Press.

Harvey, D. (1996b). Cities or urbanization?. City, 1(1-2), 38-61. https://doi.org/10.1080/13604819608900022

Ibañez, D., \& Katsikis, N. (2014). Editorial. In D. Ibañez \& N. Katsikis (Eds.), New Geographies 06: Grounding Metabolism (pp. 2-9). Cambridge: Harvard University Press.

Larkin, B. (2013). The politics and poetics of infrastructure. Annual Review of Anthropology, 43, 327- 43. https://doi.org/10.1146/annurev-anthro-092412-155522

Lefebvre, H. (1970). La révolution urbaine. Paris: Gallimard.

Merrifield, A. (1993). Place and space: a Lefebvrian reconciliation. Transactions of the Institute of British Geographers, 18(4), 516-531. https://doi.org/10.2307/622564

Mishra, P. \& Narain, V. (2018). Urban canals and peri-urban agrarian institutions: A study of Budhera village in Gurgaon. Economic and Political Weekly, 53(37), 51-58.

Rodgers, D., \& O'Neill, B. (2012). Infrastructural violence: Introduction to the special issue. Ethnography, 13(4), 401-412. https://doi.org/10.1177/1466138111435738

Sennet, R. (1996). Flesh and stone: The body and the city in western civilization. London: WW Norton \& Company. 


\section{Citizenship at the margins: Exploring slum rehabilitation in an urban fishermen settlement in Kerala}

Aarathi G; Centre for Development Studies

The paper analyses the transformations of social, spatial and political geography of a slum in the outskirts of the Trivandrum city under the inflow of capital in the form of a megatransshipment container terminal project, the merger of the suburban panchayat to the municipal corporation and subsequent implementation of a centrally sponsored slum rehabilitation programme. The study portrays a detailed analysis of the newly acquired urban citizenship status of the inhabitants of Mathippuram, a Muslim fishing workers' hamlet chosen for rehabilitation under the RAY (Rajeev Awas Yojana) project. It further examines how one of the most excluded, or in other words, 'an outlier community in Kerala Model of development' (Kurien, 1995) exerts their right to the city under a neoliberal form of urban governance. Are they passive beneficiaries or active citizens? Does participation ensure citizenship? What is the role of the urban poor in shaping the urban spaces in Kerala? This study carefully examines these questions through the lenses of slum rehabilitation programme implemented in the region.

Vizhinjam, the study area, is a small coastal town in the outskirts of Trivandrum city, lying 3 $\mathrm{km}$. away from the Kovalam beach: a tourist hotspot in Kerala. The suburban panchayat (Vizhinjam Grama Panchayat), along with four other panchayats-Sreekariyam, Kazhakkoottam, Kudappanakunnu and Vattiyoorkavu-were merged to form the Thiruvananthapuram Corporation in 2010 citing reasons that an increased size of population will make the corporation eligible for central government programmes like JNNURM, which targets cities that have more than one million population. Hence, merging of the panchayats was the response of the Kerala State to 'the big city bias' (Kundu 2014) of the centre's urban policy. The merger was expected to double the spending on development programmes in this region and development of this area was expected to decongest the core city. The region, which constitutes traditional fishermen hamlets, has also seen a huge influx of capital investment for high-end luxury hotels like the Leela Palace in the near past. It also falls in the Kazhakoottam-Poovar corridor where a real estate boom can be witnessed after the widening of Trivandrum National Highway Bypass. Furthermore, as mentioned before, a massive investment of ₹ 7,525 crores is underway for constructing Vizhinjam International Deep-Water Multipurpose Seaport in the region. The government of Kerala, amidst several oppositions has signed an agreement with the Adani group for construction of the port in 2015. Kerala is known to have pursued a different policy approach towards the roles of government and capital; it has subtly started embracing neoliberalism (Kennedy, 2014). This is evident from the agreement made by the state government with the Adani group for building the port, which is adversely affecting the livelihood opportunities of many fishermen in Vizhinjam locality, especially the 'mussels collectors'. Local politics of Kerala, which was characterised by the mistrust of the private sector, started to change in the 1980s (Kennedy et al. 2013) and this change in attitude of the government towards the private sector is argued as a transition from 
the logic of class struggle to class compromise of the party CPI(M) (Heller, 1995). But with the central government policies unleashing neoliberalism, Kerala finds it harder to retain its welfare state nature because of its limitations as a provincial state.

Mathippuram slum area in Vizhinjam, which lies close to the Adani project site was selected for slum rehabilitation under RAY in Thiruvananthapuram. That the slum was selected for rehabilitation is not mere coincidence. From the field survey it was clear that the slum's proximity to the Vizhinjam Port was instrumental for this selection; which does not mean that the slum does not deserve to be selected for a rehabilitation project. There was no collective demand from the people for a housing project, which was implemented in a top-down fashion. In fact, many of the beneficiaries feared displacement due to the informality of the lend tenure. They also do not perceive public housing as their right. The participation of the beneficiaries in the planning and implementation of housing is minimal (one or two public meetings), which is contrary to the public's expectations as Kerala is known for its political and financial decentralisation and the Peoples' Planning model. On an individual basis the beneficiaries were in constant contact with the ward councillor, raising their concerns. Decentralisation is supposed to result in enhancing local planning, service delivery, and empowerment of the local population as local bodies will be able to formulate policies on the basis of demands raised by local citizens (Rodinelli, et al 1989, Manor 1995, Crook and Manor, 1998, Blair, 2000). But, most of the urban development programmes are designed at the centre and there is less scope for the subnational governments to alter them. The beneficiaries actively raised their concerns in the meetings conducted by the municipal corporation and with the ward councillor but most of their suggestions were ignored citing that the criteria is fixed and cannot be modified. For example, one of the suggestions was to have a 'back door'. It was impossible for the community members to imagine a house without a back door. Some reasons for this were religious such as: men and women do not enter through the same door to attend a funeral; another reason was thatthe back door helped women to run away from the houses to escape domestic violence. These homogenised urban development programmes leave no room for such cultural aspects and requirements of the communities.

Further, the neoliberal urban development programmes also force the state governments to 'roll back' from delivering basic services (Harvey, 2008; Peck and Tickell, 2002). The beneficiary contribution exerts heavy financial burden on the urban poor. Additionally, the delay in implementing and not providing transit accommodation has forced many families to live away from their habitat, in rented houses which has added to the financial hardship of these families. In the case of Mathippuram, the rehabilitation programme, in fact, just reproduced the inequality that persisted before. For example, no proper sewerage facility and poor quality of septic tanks which get filled in every few months leaves them in the same or even worse living environments. There was also a potentially dangerous, false perception for many beneficiaries that local development programmes implemented in the region is by the Adanis, when all projects except one were funded and implemented by the state. Some even presumed that they got housing through the Adani project. 
This study, like many similar academic works (Harriss, 2005, 2007; Smitha, 2010; Chatterji, 2004), observes that associational activity and civil society activism is minimal among the urban poor. No residential welfare associations or community groups actively engage in housing or other issues related to the community in the region, but there are high levels of political participation. The ward councillor is considered as the primary point of contact for demanding needs or raising complaints.

The paper ultimately argues that centrally planned top-down implementation of most urban development programme leaves less or no scope for urban local self-government in tailoring projects to suit the specific needs of local communities. The distinct political geography of Kerala, shaped through renaissance movements, political struggles, influences of communist and socialist ideas, political and financial decentralisation of state power, etc. seems insufficient in empowering the urban poor to become active citizens of the city. The paper also argues that although civil society and private participation have become the new 'mantra' of urban development programmes in the post-liberalisation era in India, in reality the formal participation of the urban poor in a few mandatory meetings organised to ensure citizen participation do not guarantee that they have acquired the capability to mould programmes according to their needs. The citizenship of the urban poor is far from what Lefebvre's (1996) idea of 'right to the city' is. Centrally planned homogenised programmes not only undermine the role of urban local bodies but also make the urban poor passive beneficiaries rather than active citizens. It can be further argued that de-politicised urban governance reduces the role of local governments to mere implementing agencies of the central government. The study finally argues that capital produces or reproduces urban spaces leaving minimal agency or collective power for the poor urban dwellers in transforming the city spaces they live in.

\section{References}

Blair, H. (2000). Participation and accountability at the periphery: Democratic governance in six countries, World Development, 28(1), 21-39. https://doi.org/10.1016/S0305750X(99)00109-6

Chatterjee, P. (2004). The politics of the governed: Reflections on popular politics in most of the world. New York: Columbia University Press.

Crook, R., \& Manor, J. (1998). Democracy and decentralization in south Asia and west Africa: Participation, accountability and performance. Cambridge: Cambridge University Press.

Harriss, J. (2005). Political participation, representation and the urban poor. Economic \& Political Weekly, 40(11), 1041-1054.

Harriss, J. (2007). Antinomies of empowerment: Observations on civil society, politics and urban governance in India. Economic and Political Weekly, 42(26), 2716-2724.

Harvey, D. (2008). The Right to the City, New Left Review, 53(53), 23-40.

Heller, P. (1995). From class struggle to class compromise: Redistribution and growth in a south Indian state, Journal of Development Studies, 31(5), 645-672. https://doi.org/10.1080/00220389508422384

Kennedy, L. (2014). The politics of economic restructuring in India: Economic governance and 
state spatial rescaling. London, New York: Routledge.

Kennedy, L., Robin, K., \& Zamuner, D. (2013). Comparing state-level policy responses to economic reforms in India. A subnational political economy perspective. Revue de la régulation. Capitalisme, institutions, pouvoirs, (13). Retrieved from https://regulation.revues.org/10247.

Kundu, D. (2014). Urban development programmes in India: A critique of JNNURM. Social Change, 44(4), 615-632. https://doi.org/10.1177/0049085714548546

Kurien, J. (1995). The Kerala model: Its central tendency and the outlier. Social Scientist, 23(1-3), 70-90. https://doi.org/10.2307/3517892

Lefebvre, H., Kofman, E., \& Lebas, E. (1996). Writings on cities. Cambridge, USA: Blackwell Publishers.

Manor, J. (1995). Democratic decentralization in Africa and Asia. IDS Bulletin, 26(2), 81-88.

Peck, J., \& Tickell, A. (2002). Neoliberalizing space. In N. Brenner \& N Theodore (Eds.), Spaces of Neoliberalism: Urban Restructuring in North America and Western Europe (pp. 33-57).

Oxford, UK: Blackwell.

Rondinelli, D. A., McCullough, J. S., \& Johnson, R. W. (1989). Analysing decentralization policies in developing countries: A political-economy framework. Development and Change, 20(1), 57-87. https://doi.org/10.1111/j.1467-7660.1989.tb00340.x

Smitha, K. C. (2010). New forms of urban localism: Service delivery in Bangalore. Economic \& Political Weekly, 45(8), 73-77. 


\section{Lost opportunities: A case study of Khushkhera-Neemrana-Bhiwadi investment region}

Druti Gangwar, Ridima Kanwal; School of Planning and Architecture, Bhopal

\section{Introduction}

In the past two decades, India has seen rapid urbanisation with growth in the industrial and service sectors. India became an important net foreign exchange earner as the service sector's contribution of about 66.1 per cent of its gross value added growth in 2015-16 (Ministry of Finance, 2016). Once a totally agrarian economy, it has now become progressive towards industrialisation, after the big revolutionary step of economic liberalisation in 1991. This progress has led to rapid urbanisation and it is seen that in the past decade there has been enormous increase in the number of urban centres such as the increase in census towns from 1,362 in 2001 to 3,894 in 2011, not because of the rural to urban migration, but due to the reclassification of rural settlements into urban ones (Pradhan, 2013). With the rural-urban interdependency and this urban transformation, settlements have become agglomerated and the economy has become more region-oriented. A national push for industrial development has resulted in super-agglomeration; one such example is the DelhiMumbai Industrial Corridor (DMIC) which covers various settlements in Uttar Pradesh, Delhi, Haryana, Rajasthan, Gujarat, Maharashtra, and Madhya Pradesh. Though the project was conceived in 2007, it has been a story of delays-it took around four years to be approved by the Cabinet in 2011 and the first chunk of developed land was leased in Shendra-Bidkin, Maharashtra for continuing the project work in 2017 (Pattanayak, 2018). Of all states and the national capital, Rajasthan has the largest land under the project, yet the project has progressed least in this state.

This paper is set to bring out the critical view-point on the potential for the Rajasthan region in the DMIC project and whether local needs and aspirations are met in the proposed projects. The study is focussed on analysing the potential of cities in the early bird projects in Khushkhera-Bhiwadi-Neemrana Investment Region (IR) and the opportunities brought in by the project. It is seen that such investment projects are proposed to generate huge amounts of employment (Singla, Kapoor, \& Batchu, 2015), but they should be in accordance to the local skills, needs and requirements.

\section{Literature Review}

India is a growing and its diverse economy with GDP of 6.3 per cent (2017-18) is expected to grow to 7.3 per cent in 2018-19 from primary, secondary and tertiary sectors (Financial Express, 2018). Although India has been an agrarian economy, it has seen significant growth in the industrial and service sectors in the past three decades. In the 1970s and 80s, India faced huge economic crisis due to more focus on capital-input-oriented growth and less productivity-oriented growth. India being a closed economy due to restrictions on Foreign Direct Investments (FDI), state sponsored development, high and complex taxes, etc. suffered 
from three major macro-economic crises: (i) acceleration of inflation (16.3 per cent in August 1991); (ii) unsustainable fiscal deficit (6.6 per cent in 1991, 30 per cent debt-service burden, and hence, debt trap); and (iii) fragile balance of payments situation (current account deficit of 3.69 per cent of GDP in 1991) (Bag \& Gupta, 2012). It was only in 1991, with the introduction of economic liberalisation that the FDI was unleashed, encouraging privatisation of public sector enterprises, relaxation on regulation and licensing of industries, reduction of taxes on imports, more focus on more productive sectors like industries, manufacturing and services than on agriculture, and with that the Indian economy gained boost in the industrial sector (Biswas, 2016).

Since economic liberalisation, India has gained an accelerated pace of growth and the urban areas, centres for industrial growth, have contributed largely towards it. As per a study by Central Statistical Organisation, urban centres being the hub of manufacturing and service sectors, have contributed to about 55 per cent of the output in 2012 (Revi, Koduganti, \& Anand, 2014). In the present era, urban centres are growth engines, which attract investment opportunities and support both urban and rural livelihoods. In the past two decades, a great phenomenon of increase in urbanisation has taken place. Nearly 30 per cent of urban growth during the last decade was due to reclassification of existing settlements and not from rural to urban migration. This has led to formation of urban agglomerations with increased ruralurban interdependencies and distribution of services in the higher and lower order settlements. Such agglomerations have huge potentials of being developed as regional economies and thus attract the nation's interest for investments. This has led to the creation of Special Economic Zones (SEZs), National Industrial Manufacturing Zones (NIMZs), and industrial corridors which are not restricted only to one or two urban centres and jurisdictions, but influence the nearby urban and rural settlements too and hence, become 'spaces of exception' both in terms of economy and governance (Anand, Arakali, Jana, Koduganti, \& Sami, 2015).

For such projects, there are several constraints in supporting regional infrastructure such as land, labour, capital, transportation, power, etc. and the lack of co-ordination between various governments and line ministries results in improper functional overlapping and hence, faulty planning of these settlements. In order to embark on the process of planned urbanisation with manufacturing as the key economic driver and to give a strong impetus to the country's industrial/manufacturing development, the Government of India (Gol) introduced the DMIC Project as the first Industrial corridor in 2007.

\section{The project and methodology}

The DMIC project aims to create smart and sustainable industrial cities and hubs by leveraging high speed, high capacity connectivity with an enabling policy framework by providing a backbone through the Western Dedicated Freight Corridor (DFC) along the 1,500 km. stretch, which will reduce logistic costs and time between Dadri near Delhi to Jawaharlal 
Nehru Port in Mumbai from 14 days (currently) to about 14 hours (Ahuja, 2018). The project is handled by a special purpose vehicle i.e. the DMIC Development Corporation Limited which was incorporated in January, 2008. The project envisions incorporating sustainability and development, in 24 manufacturing cities with world-class infrastructure, convenient public transport, power management, and efficient water and waste management systems. After completion and development of these nodal towns, the pressure on burgeoning cities will ease and will be the hallmark of a resurgent India. The current equity shareholders in DMICDC include Gol, represented through the Department of Industrial Policy and Promotion (DIPP), Japan Bank for International Cooperation (JBIC) and financial institutions such as Housing and Urban Development Corporation (HUDCO), India Infrastructure Finance Company Limited (IIFCL), and Life Insurance Corporation (LIC) (DMIC Annual Report, 2018).

After the long delays, the project is now in full swing, in the implementation stage and construction work is being carried out in Gujarat, Maharashtra, Uttar Pradesh and Madhya Pradesh, with finalised land disposal policies and initiation of land allotment process. Compared to the projects in the other states, the maximum area falls under Rajasthan and has been the slowest to proceed in project implementation (DMIDC, 2011). From the early bird projects in the Khushkhera-Bhiwadi-Neemrana Investment Region (IR), Rajasthan, located $50 \mathrm{~km}$. from the dedicated freight corridor is envisaged to be developed as a global city. Spread over 40,000 acres it is to be developed as an industrial hub with a focus on knowledge-driven manufacturing targeting towards innovation, creation, and production.

The project will include development of the automobile industry; biotechnology; IT/ITES; the health sector; widening of $81 \mathrm{~km}$. stretch of the Bhiwadi-Alwar link; development of the compact city to reduce travel time with minimal relocation of the existing population; and protection of ecologically sensitive zones, river-beds and agricultural zones in the city fabric, by using technologies for the efficient use of water, water harvesting, recycling and solar energy.

Phase I includes the development of 120 sq. km. land for a residing population of 1.28 million and cater to the employment of 0.55 million people. Three major early bird projects for this area are: 'Aerotropolis' in 24 sq. km. area, a Knowledge City, and 50 km. long road link between Neemrana and Bhiwadi via Ajarka. Additionally, DMICDC plans to set up six gas based power plants to foster clean and green energy generation in the region (DMIDC, 2011). After studying the District Industrial Profile Report 2015-16, it was found that Bhiwadi and Neemrana have huge potentials for Micro, Small and Medium enterprise (MSME) clusters of cement, stone grit, cement and fly ash brick, paints, electronics, etc. which will support the local economy and livelihood. In this paper, the overall DMIC project will be studied with a focus on the influence of the DMIC early bird projects on the towns and city in the Rajasthan region. The potential of the city and towns will be analysed to understand the role of these settlements in the DMIC region and the development that the project would bring in through the economy and lives of people. In the later part of the paper, an overall comparison will be 
made to understand the delays caused in the DMIC projects in Rajasthan and future prospects in different scenarios would be stated.

\section{Conclusion}

DMIC has huge potential of developing the region but in Rajasthan it has fallen prey to issues like delayed compensation provision, de-acquisition of land, and unpredicted externalities like bankruptcy of the Infrastructure Leasing \& Financial Services Ltd. which clearly defines lost opportunities for the DMIC project in Rajasthan. This has highly affected investment in the project and the region as the IL\&FS Ltd. is a private partner in the Special Purpose Vehicles (SPVs) for the project. This will further delay the development of the project and that of Rajasthan and hence, will also affect the total DMIC project as this region is an important link in the logistics movement between Delhi and Mumbai. With the potential of Khushkhera, Bhiwadi and Neemrana areas in the MSMEs, which form the local economy of these settlements, the sustainability and viability of the envisaged projects under DMIC is questionable. It is important to understand the compatibility of the proposed projects like Aerotropolis, Knowledge City and industries; and whether the basic infrastructure and skills required to establish such new developments are present in the region or not. Finally, the sustainability of these developments is relative to the aspirations and needs of the people. Through this study, the impact of projects under DMIC region on the economy of Khushkhera, Bhiwadi and Neemrana areas and their role with respect to the potential and their compatibility with the envisaged projects will be understood.

\section{References}

Anand, S., Arakali, A., Jana, A., Koduganti, J., \& Sami, N. (2015). Manufacturing cities: industrial policy and urban growth (IIHS-RF Paper on Manufacturing Cities). Bangalore: Indian Institute for Human Settlements.

Ahuja, M. (2018, February 16). Move to de-acquire land for DMIC project hits Alwar farmers. Rajasthan.

Bag, S., \& Gupta, A. (2010). Performance of Indian economy during 1970-2010: A productivity perspective. Retrieved from https://editorialexpress.com/cgi-

bin/conference/download.cgi?db_name=FEMES12\&paper_id=481

Biswas, A. (2016). An overview of spatial policy in Asia and European countries: India. Japan: MLIT. Retrieved from http://www.mlit.go.jp/kokudokeikaku/international/spw/general/india/index_e.html

Delhi - Mumbai Industrial Corridor (DMIC). (2011). DMICDC corporate brochure. Retrieved from https://dmicdc.com/downloads/corporate-brochure

Delhi - Mumbai Industrial Corridor. (2018). 9th Annual report. New Delhi: DMICDC. Retrieved from http://www.dmicdc.com/Uploads/Files/37df_09THAnnualreport_DMICDC201617.pdf

Financial Express Online. (2018, January 29). Economic survey 2017-18: India GDP growth rate seen bouncing back 7-7.5\% in FY19. Financial Express. Retrieved from 
https://www.financialexpress.com/budget/economic-survey-2017-18-gdp-growth-indiagrowth-rate-rebound-arun-jaitley/1034135/

Pattanayak, B. (2018, July 9). \$100-billion Delhi-Mumbai Industrial Corridor (DMIC) project hits land hurdle in Rajasthan. Financial Express. Retrieved from

https://www.financialexpress.com/india-news/100-billion-delhi-mumbai-industrialcorridor-dmic-project-hits-land-hurdle-in-rajasthan/1236604/

Pradhan, K. C. (2013). Unacknowledged urbanisation: New census towns of India. Economic and Political Weekly, 48(36). 43-51.

Press Information Bureau. (2016). Economic survey 2015-16: Services sector remains the key driver of economic growth contributing almost $66.1 \%$ in 2015-16. Retrieved from http://www.pib.nic.in/newsite/PrintRelease.aspx?relid=136868

Revi, A., Koduganti, J., \& Anand, S. (2014). Cities as the engines of inclusive development. (IIHSRF paper on Indian Urban Economy). Bangalore: Indian Institute for Human Settlements.

Singla, M., Kapoor, P., \& Batchu, Y. (2015). Impact cities based on proposed industrial corridors in India. Retrieved from https://www.commonfloor.com/guide/wpcontent/uploads/2015/07/Impact-Cities-based-on-proposed-Industrial-Corridors-inIndia.pdf 


\section{The rescaling of the State in the Dholera Smart City}

Rakib Akhtar, University of Oxford

\section{Introduction}

Over the last few years in India, smart cities have often been branded as an urban panacea. The proposed Dholera smart city [also called the Dholera Special Investment Region (SIR)] in the western Indian province of Gujarat is the first prototype in India to be built entirely in greenfield. Located in a remote area, around $120 \mathrm{~km}$. from Ahmedabad, the project is going to acquire a massive $920 \mathrm{sq}$. km. of agricultural lands across 22 villages directly affecting a population of more than 39,000. Dholera SIR is an important node in the Delhi Mumbai Industrial Corridor (DMIC), a $\$ 100$ billion infrastructure project connecting the financial capital Mumbai with the administrative capital, New Delhi, by a 1,500 km. long dedicated freight corridor along which a number of industrial zones and smart cities are to be built. Through DMIC and Dholera SIR, the federal and the provincial governments are trying to deal with urbanisation, economic growth, and job generation in very particular ways.

\section{Modernisation to Liberalisation}

After centuries of British rule, the 'development project' of India drew legitimacy from aspirations of the nationalist movements and the trust people placed in their leaders ${ }^{1}$. It was essentially premised on centralised control over natural resources and the idea that citizens' need to go through sacrifices for the nation to develop. Even urbanisation projects were part of the state's attempt at nation-building through building of cities like Chandigarh (Scott, 1998). Butduring this period, cities suffered massively with the twin phenomenon of anti-local and anti-urban philosophy of both, the federal and provincial governments (Shatkin, 2017).

Following a series of domestic and global events during the 1970 s and 1980s, which affected the course of policy-making, bringing in what has widely been termed as neoliberalisation ${ }^{2}$, India witnessed a major change in economic policies in the following decades. India approached the International Monetary Fund for loans in 1991, creating a platform to introduce a host of policies to open up the economy to private and global players. This set of policies subsequently came to be associated with the liberalisation of the Indian economy. An ideological shift in the Indian political and economic landscape was reached as the emphasis shifted to rapid, high economic growth driven by private capital, both foreign and domestic. The provincial governments were encouraged to source funding from transnational investors and this led to an inter-provincial competition.

This competition resulted in easing restrictions on the transfer of various resources like land and mineral ores, which were hitherto public to private hands. Land became the most saleable asset as provincial governments, in their attempt to woo capital, strategised ways to assemble land parcels in the form of industrial enclaves or infrastructure projects where investments could be made. A host of new policies were evolved leading to changes in land- 
related policies which (Sud, 2012), in the case of Gujarat, calls the travel from 'land to the tiller to land liberalisation'. DMIC and Dholera SIR are part of this genealogy. Through these strategies, the provincial governments are increasingly influenced by their interactions with transnational actors like international donor agencies, multinational corporations or organised diasporic groups.

\section{Theoretical Framework}

Against this contextual backdrop, the role of the state ${ }^{3}$ is studies, which the author of this paper claims, to be entangled and blurred with the society as well as with capital. In its endeavor to deliver the Dholera SIR, the state plays two very different roles simultaneously. It has acquired a new top-down approach through a newly instituted parastatal. Secondly, the state is deeply involved in the daily lives of its rural constituents which eventually affect the process as well as the outcome of the project. It is found that both the avatars of the state pervade the non-state spaces and also let non-state forces to pervade the state spaces. Consequently, the difference between what is state and what is non-state is blurred. This blurring, pluralisation or porosity of the state has been explored in social science scholarship, especially through ethnographies; and hence it is not claimed that this is a new phenomenon and outcome of rescaling. (See Gupta, 1995; Das and Poole, 2004).

To situate these transformations, what I follow is a strand of scholarship from urban geography, the state rescaling, which has analysed the changing role of the state in the neoliberal era and how that has impacted the due process and outcomes. This scholarship focusses on how states adapt to changes in capitalism by reconfiguring their relation to space and territory (Brenner, 2004; Brenner et al., 2003). It seeks to explain the shifting of nationstates from a Keynesian-inspired model to a supply side model targeting investments and promotional policies (Klink, 2013). Cities and city regions in particular have been targeted and are leveraged as growth engines in regional and national economies, a trend observed in both advanced and emerging economies.

State rescaling in India remains under researched except for research by Loraine Kennedy [(2014), (Kennedy \& Sood, 2018)] and Sami \& Anand (2016). Kennedy's scholarship is seminal with respect to India. She argues that there are two different strands within this scholarship. First is the rescaling in a 'narrow sense', which refers to 'the changing organisation of state territoriality; the evolving role of borders, boundaries, and frontiers; and the changing intranational geographies of state territorial organization and internal administrative differentiation' (Brenner et al., 2003). The second reflection, 'the integral sense' of state space is crucial in widening this framework. According to Kennedy, the conceptions of scale are not restricted to spatial aspects. A scale has both political and social texture and emerges as a result of social processes that involve an appropriation of space. Hence, the emphasis shifts to the 'scalar dimensions of political and social practices' rather than focussing on phenomena occurring at various ready-made scales (e.g. local, national, global, etc.). 
As an outcome of this rescaling, a host of institutions and arrangements like Parastatal, Special Purpose Vehicle, or Public Private Partnership have emerged. Through these institutions, the state itself straddles through spaces which were otherwise non-state and similarly corporates overlap hitherto public spaces. This has certainly led to the pluralisation of the state (Chandhoke, 2003) as it becomes porous to various groups with the deepening of democracy. As Sud (2017) argues, the state itself is networked as it overlaps formal roles along with informal or shadow dimensions. These interplays and networks bring into light how and why problematising the entity called state is key to understanding the evolving dynamics and hence, there is a need to further the frame of state rescaling. Taking rescaling as a given, which the literature and the primary data on Dholera shows, this study throws up some questions: what happens to the state after rescaling? Does it still remain a concrete entity? Or is it made porous by different stakeholders? In this way, the current study contributes to an integral sense of the state rescaling strand.

\section{DHOLERA: Canal to Smart City}

'Development neither reaches us nor leaves us. It's an illusion' - A farmer during an interview

Dholera is the quintessence of the Indian state's journey from a modernising to a liberalising state. In the 1960s, when the Narmada Dam was being planned, Dholera was notified as one of the beneficiaries of the project, which were never constructed. The Kalpasar Project, which has not yet started, was announced by the provincial government in the 1980s. Its ambitious plan included building a dam across the Gulf of Khambhat for establishing a huge fresh water reservoir, a 10-lane road link was to be set up over the dam, significantly reducing the distance between the region of Saurashtra, and south Gujarat.

In the 1990s, there were proposals for reviving the ancient Dholera Sea Port and it was officially launched in 2006-07. In 2009, Dholera SIR was launched, later translated into the Dholera Smart City. Since then, Dholera has witnessed a massive increase in its land prices, from a mere ₹ 2,500 per acre to ₹ 2,50,000, and now ₹ 25,00,000. Treating land as the analytical framework and moving away from the well explored state vs farmer narrative, this study looks at the multiplicity of outcomes.

It is found that:

(i) a select few amongst the elites co-opted and incorporated themselves to become land dealers and protestors at the same time

(ii) a considerable number of them became middlemen in the land deals

(iii) most land sellers have strategically sold a certain portion of their lands at the appreciated prices to payback previous loans and continue to cultivate on the leftovers till their land is notified and taken away by the Dholera SIR Development Authority (DSIRDA)

(iv) another section of the locals who are completely against any loss of land have gone to the High Court and managed to get land acquisition stalled. 
Although, this is no representation of the masses, it shows that once the project is launched, citizens lobby for their own interests. Practices of the state are highlighter here, which blur the boundaries between formal vs informal; state vs non-state; or state vs shadow binaries. Such blurring is commonplace in a province like Gujarat as documented in numerous scholarships (Sud, 2012; Berenschot, 2011). In these villages, government officials who moonlight for private land buyers and become instrumental to land transactions, are commonly found in the ruling Bharatiya Janata Party's (BJP) office and have private offices in the village market place to offer real estate related services. People who are active with the Rashtriya Swayamsevak Sangh (RSS) with easy and manipulative access to land offices, become middlemen, and they are key to any successful land transactions. The local real estate dealers in Dholera mimic formal institutions like Vibrant Gujarat, bringing in bureaucrats and investors on the same platform to address issues faced by them.

These few villagers have managed to become large land dealers moving away from petty businesses dealing with grains or roadside tea stalls. These vignettes also underline how people withonly a certain caste background or political affiliations have been able to capture such upward mobility. Hence, as the state is rescaled, and is politically captured, it attracts local alliances, compliances as local elites and middlemen join the project.

Secondly, this paper analyses the functioning of the more technocratic, newly established institution of the state: DSIRDA which is the Regional Development Authority and is tasked with delivering the project and is based in Gandhinagar, the provincial capital. From interviews with its governing body members, the CEO, bureaucrats, planners and data collected from primary observations during multiple visits to the office, the author discusses politicisation and an autocratic approach of the agency.

In its everyday working, DSIRDA is often represented by the private consultant, AECOM (Architecture, Engineering, Consulting, Operations, and Maintenance) despite being a government organisation. DSIRDA also shares its office physically with AECOM. True to the revolving door phenomenon, personnel working with DSIRDA go on to join AECOM at the same office, after retirement. The paper also narrates the story of a key bureaucrat from DSIRDA who started one of the most successful real estate projects in Dholera. Importantly, decision making in DSIRDA or alike, may usually be top-down, opaque and insulated from local practices of democratic accountability but it is not always above daily politics within the government. Thus, interactions within the DSIRDA and its interaction with the outside world, with the local population losing lands, demonstrate both the techno-managerial approach as well as practices of informality. 


\section{Conclusions}

The framing of the SIR Act, 2009 was a step to territorially reorganise governance structure overnight and is a rescaling in the 'narrow sense'. It can be interpreted as part of a larger restructuring strategy as its outcome reflects the relevance of the 'integral sense'. Through this paper based on an eight-month long ethnography in Dholera and Ahmedabad, the study analyses the critique of state rescaling and its applicability in the global South and hence, India. As explored above, scholarship is taken forward by deconstructing the entity of the state in the everyday lives of stakeholders in an infrastructure project and through the framework of the state rescaling.

\section{Endnotes}

${ }^{1}$ This is no doubt a romanticised version the Indian modernist development project. For a challenge, see Chatterjee (1997) on post-independence, elitist passive revolution.

${ }^{2}$ Neoliberalism, primarily, refers to the laissez-faire economic liberalism practised since the 1980s. It includes wide-spreading economic liberalisation policies such as privatisation, freetrade agreements between nations, state deregulation, and reductions in government spending in order to increase the role of the private sector in the economy 3 The author uses 'state' as a concept similar to the 'government' referring to institutional aspects, including bureaucracy, political executive and police machinery (Sud, 2007). The differences between state and government are not detailed here. The state is viewed as a multi-faceted, internally differentiated, pluralised entity rather than a homogenous one that either constrains private economic activity or administers the interests of a bourgeoisie class.

\section{References}

Berenschot, W. (2011). Riot politics: India's communal violence and the everyday meditation of the state. London: C. Hurst \& Co. (Publishers) Ltd.

Brenner, N. (2004). Urban governance and the rescaling of statehood. New York: Oxford University Press.

Brenner, N., Jessop, B., Jones, M., \& MacLeod, G. (Eds.). (2003). State/Space: A reader. Malden, MA. \& Oxford: Blackwell Publishers.

Chandhoke, N. (2003). Governance and the pluralisation of the state: implications for democratic citizenship. Economic and Political Weekly, 38(28), 2957-2968.

Chatterjee, P. (1997). State and politics in India. New Delhi: Oxford University Press.

Das, V., \& Poole, D. (Eds.). (2004). Anthropology at the Margins of the State. Santa Fe, NM: School of American Research Press.

Gupta, A. (1995). Blurred boundaries: The discourse of corruption, the culture of politics, and the imagined state. American ethnologist, 22(2), 375-402.

Kennedy, L. (2014). The politics of economic restructuring in India: Economic governance and state spatial rescaling. New delhi: Routledge.

Kennedy, L., \& Sood, A. (2019). Outsourced urban governance as a state rescaling strategy in Hyderabad, India. Cities, 85, 130-139. https://doi.org/10.1016/j.cities.2018.09.001

Klink, J. (2013). Development regimes, scales and state spatial restructuring: Change and 
continuity in the production of urban space in metropolitan Rio de Janeiro, Brazil. International Journal of Urban and Regional Research, 37(4), 1168-1187. https://doi.org/10.1111/j.1468-2427.2012.01201.x

Sami, N. \& Anand, S., (2016). Scaling up, scaling down: State rescaling along the Delhi-Mumbai Industrial Corridor. Economic \& Political Weekly, 51(17), 50-58.

Scott, J. C., (1998). Seeing like a state: How certain schemes to improve the human condition have failed. New Haven, London: Yale University Press.

Shatkin, G. (2017). Cities for profit: The real estate turn in Asia's urban politics. Ithaca, NY: Cornell University Press.

Sud, N. (2007). From land to the tiller to land liberalisation: The political economy of Gujarat's shifting land policy. Modern Asian Studies, 41(3), 603-637. https://doi.org/10.1017/S0026749X06002459

Sud, N. (2012). Liberalization, Hindu nationalism and the state. New Delhi: Oxford University Press.

Sud, N. (2017). State, scale and networks in the liberalisation of India's land. Environment and Planning C: Politics and Space, 35(1), 76-93. https://doi.org/10.1177/0263774X16655801 


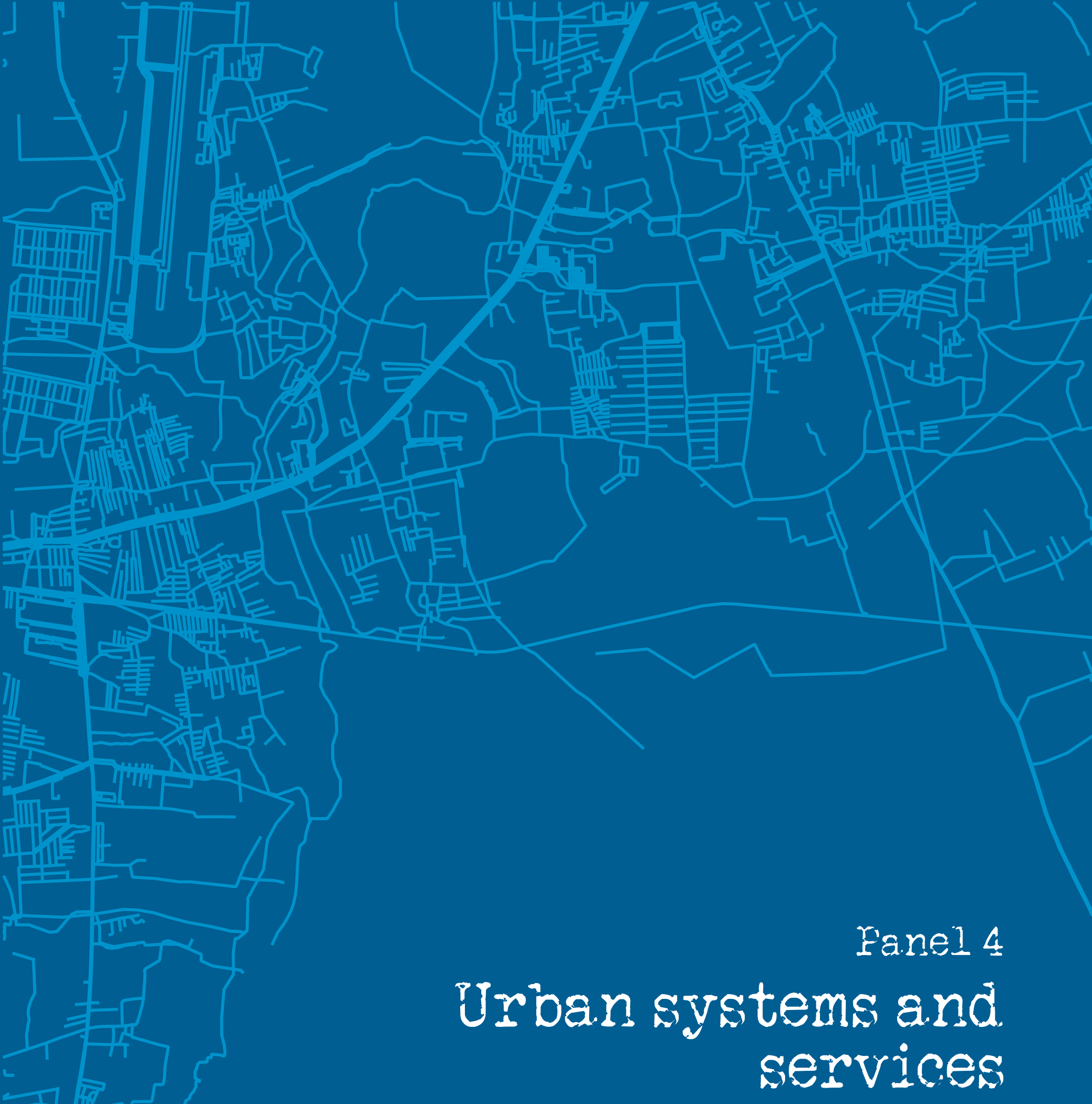




\section{Delivery of water and sanitation public services under Swachh Bharat Mission-Urban (SBM-U) at New Delhi railway station}

Deepak Kumar; Tata Institute of Social Sciences

Delivery of services under a policy is the main aspect of the success of policy. It is the intention of the government to deliver policy. It is also the intention of the delivery outcome which derives success or failure of services. It is the expectation of the people which should matter the most for any government towards the policy. This paper tries to understand the situation of people's perspective at the New Delhi railway station from the perspective of policy service delivery. How do people avail water and sanitation services at the New Delhi railway station? This paper tries to understand people's perspective by taking the help of the 'Citizen Report Card (CRC)' as a tool to learn about the delivery of water and sanitation. Considering the spending and moving nature of people from one place to another, the ambitions of people needs to be understood from the perspective of service delivery. Hence, there is a need to study the delivery of services such as water and sanitation under the Swachh Bharat Mission-Urban. As per public service delivery water availability scores well on the rating scale with more than 6 out of 10 , where 10 is best and 0 is worst. Similarly, when it comes to sanitation services, people rated not more than 4 out of 10 , which is not a good sign. This paper tries to study the behaviour of people and their expectations from SBM-U at the New Delhi railway station. The study had a sample size of 40 and considered a convenience sampling method. This paper tried to explore in the capital city Delhi due to its specific nature of being regarded as a 'world city' or 'megacity'.

Key Words: New Delhi railway station, Water and Sanitation, and Public Service Delivery

\section{References}

Ministry of Urban Development. (2017). Swachh Bharat Mission - Urban. Retrieved from http://164.100.228.143:8080/sbm/content/writereaddata/SBM_Guideline.pdf

E-learning on Citizen Report Card Toolkit. (2016). Retrieved from http://pacindia.org/2016/06/20/citizen-report-card-toolkit/ 


\section{Poverty and transport accessibility in Bengaluru: The need for a}

gendered perspective

\section{Pooja Sastry}

\section{Equity and transport accessibility in Indian cities}

Access or accessibility: the ability to reach desired goods, services or activities, should be the goal of all urban transport systems. ${ }^{1}$ Measures of accessibility, however, and certainly those in India, tend to study the population of a city as if it were a homogenous mass, a variable whose behaviour can accurately be measured and whose needs can be met.

Comprehensive Mobility Plans (CMPs), for example, were considered prerequisite for the submission of Detailed Project Reports for funding under the Jawaharlal Nehru National Urban Renewal Mission (JNNURM). For those cities that had already prepared a Comprehensive Traffic and Transportation Study (CTTS), such as Bengaluru, this was sufficient to ensure funding, despite the fact that a CTTS does not review the accompanying land use plan or conduct a social and environmental impact assessment. This model- whether based on a CTTS or CMP-is inadequate as a standard for the delivery of services and the building of infrastructure, for three important reasons.

The first is the most obvious, that the result of an averaged-out measurement of needs invariably ensures that the city remains inaccessible to those sections of the population whose needs are greater but the capacity to meet them is lesser than average, such as lowincome households. The second is that information on nuances and differences of perception, requirements and use of the transport system by different groups, such as the elderly as opposed to the fit, children as opposed to adults, the differently abled as opposed to the able-bodied and women as opposed to men are lost, resulting in a system indifferent and even hostile to the needs of many users. Both of these come under the general heading of what Levy calls the 'unfair distribution of accessibility'.

The third is the disproportionate allocation of resources-in this context, road space and investment in transport infrastructure - to the already privileged, those road users with the loudest voices. The poor in Indian cities today face 'spatial disadvantage's, in that the new economic order has failed to find a place for them, continuing instead to keep them on the margins. This is also 'social exclusion': the perspective that in addition to poverty, many urban citizens face the inability to participate fully in society ${ }^{4}$.

Gender is a useful perspective from which to understand the shortcomings of this standard of service-delivery, especially in India. Women traditionally perform the daily tasks that keep a household functioning: the unpaid labour of cooking, washing, and caregiving. In addition, women in cities across income groups participate in the workforce ${ }^{5}$. Women from poor households are often employed in labour-intensive professions such as construction labour 
or in factories, on lower wages than those of men. They may also be self-employed as street vendors or as domestic help: both part-time, low-paying occupations in the informal sector. Studies have repeatedly found that women in economically disadvantaged households make several more trips in a day, and for reasons other than work and are almost invariably pedestrians ${ }^{6}$.

\section{Travel choice and spatial disadvantage}

An argument against inequity in the context of 'travel choice' has been succinctly framed by Levy, who states that travel-across gender, class, social group, age and mental/physical ability-is not an actual choice in the traditional sense of maximisation of utility ${ }^{7}$. Rather, it is a series of trade-offs of how, when and even if to travel, and decisions made amid unequal relations in the household, community, and city levels. This view has been echoed by several other studies on the subject of poverty and transport: 'travels by the poor are generally fewer, take more time, traverse less distance, and rely on alternative modes more than the nonpoor ${ }^{8}$.

Several studies, in both developed and developing countries, have shown that income and gender, especially in the backdrop of structural adjustments and labour markets in the modern economy, are closely intertwined and help explain the travel behaviour and livelihoods of much of the urban population. A key reason for this is that women often accompany other members of these households, who may be spatially disadvantaged, such as the elderly, the differently abled and children. Roy goes on to define a gender-povertyspatial disadvantage link ${ }^{9}$, while Porter places transport in the context of women's access to education, health and credit facilities that may help them move out of poverty ${ }^{10}$.

Research on the travel characteristics of low-income women has found that trips to work account for a higher share of men's journeys, while shopping and trips accompanying children to their place of education account for a higher share of women's trips ${ }^{11}$. Transport deprivation may take the form of women's use of inferior modes of transport as compared with men ${ }^{12}$ owing to the priority accorded to male members of a household even when a private motorised vehicle is owned, and the consequent choice to work inside or near the home settlement owing to time-poverty. With the use of public transport comes crush loading and its attendant hazards of sexual harassment ${ }^{13}$, and unwillingness to travel after dark.

\section{Urban transport in Bengaluru}

Urban transport in Bengaluru is road-based with the exception of one stretch of the metro, and conventional bus services operate in mixed traffic within the city. The CTTS for Bangalore observes that modal split in favour of public transport is 46 per cent, which is expected to decline. Studies of traffic composition on roads indicate that the share of cars and motorcycles is increasing ${ }^{14}$. The fact is that Bengaluru directs much of its transport-related investments into building infrastructure for motorised vehicles at the cost of shrinking road space. Available non-motorised transport is central to this study, considering that studies 
elsewhere have shown that the urban poor, and especially women, are forced to rely on nonmotorised transport.

The pattern of development in Bengaluru at a time when the city faced 'neither an exponential population growth nor pressure on land"15 has been ad-hoc. As a result, the Comprehensive Traffic and Transportation Plan for Bangalore prepared by RITES in 2007 notes that Bengaluru's road network is underdeveloped in terms of size, structure, continuity and connectivity. In addition, increase in population and the city's accompanying physical expansion has put pressure not only on the city's infrastructure, notably the water supply, sanitation and solid waste systems, but also the city's transportation system. It has been noted that Bengaluru's radial-concentric structure is confronted by high-speed demographic growth and urban sprawl ${ }^{16}$, leading to long travelling distances.

This study relies on a survey conducted in the slums in Bengaluru over February and March 2013. The eight slums in which the survey was conducted were chosen on the basis of (a) distance from the city centre: whether they were core, intermediate or periphery slums; (b) the type of area in which the slum was located: close to residential areas, industries or IT parks, in low-lying areas/tank beds; and (c) whether they were evicted and rehabilitated or benefiting from the Basic Services for the Urban Poor programme under the JNNURM. Since what was known about the slum populations was limited, the sampling within each slum used methods of both probability sampling and non-probability sampling.

A questionnaire containing specific questions about the (i) household, such as number of members, household income, access to basic services and occupation of each member of the household and (ii) trips, including time of the day, distance travelled, number of trips, mode and purpose of trip, amount spent on transport and constraints faced by each person in the household was administered. The survey subjects were female members wherever possible. Twenty-five households were surveyed in each slum from the total of eight slums, leading to the collection of data on two hundred households. In addition, semi-structured personal interviews were held with two women in each slum, a total of sixteen women.

\section{Travel patterns of low-income women in Bengaluru}

Nearly two-thirds of the women walked to their destinations, while just under a third of the men walked. On the other hand, far fewer women than men relied on buses. The use of motorised vehicles was much higher among men than women, and none of the women used bicycles. When asked why they used the modes they did in interviews, the answers of the women referred to the fact that they are not granted access to motorised modes, the fact that distances were very great, and that they used the modes they could afford.

The overwhelming majority of the respondents stated that their travel is mostly work trips. Trips made by men, however, are mainly work trips, while women make many more trips for the household, or to drop children to school, in addition to work trips. Just under half of all 
trips made were less than two km., and most women travel up to two km. a day, principally on foot. More men have travel distances that vary owing possibly to the nature of their work. Most of those in the sample made no more than two trips a day, but more women than men made more than one set of trips a day, usually for non-work purposes.

It is worth noting that women travel shorter distances in a day, depend on slower modes, spend less time travelling and make more separate trips a day than men do. In general, the share of longer trips appear to increase with increasing income up to five $\mathrm{km}$. among men, but a considerable share of trips that are 10-15 km. long are made by those in the lowest income bracket, which corresponds to the resettled periphery slum, $20 \mathrm{~km}$ outside the city.

Far more women make trips for the household and to drop children to school than men do, which agrees with the fact that women make more trips per day in general. Nearly half the respondents speaking on behalf of their households indicated that they saw 'long distances' as their principal constraint. Taken in conjunction with the fact that women across income categories travel shorter distances than men do, it shows that distance is the major deterrent that women attempt, in their choices, to overcome. Other constraints were road safety, traffic congestion and safety after dark, which also came up frequently in the interviews.

\section{Understanding women's mobility}

The results of this study emphasise that distances are crucial to women's mobility, given the limited time they can afford to allocate to travel and the fact that they depend on nonmotorised modes. This means that there is a radius of travel beyond which it is difficult for a low-income woman to achieve the daily goals she sets herself. If education centres, health facilities and basic services including transport were to be made available in this radius, it would help her manage her day. In a city like Bengaluru, where motorisation is the cause for and effect of city size and sprawl, the importance of multiple centres and availability of local facilities in every area cannot be overstated.

Bengaluru's transport system, however, with its limited choice of public transport modes (the poor are largely priced out of intermediate public transport) is not one that is friendly to the poor to begin with, and sprawl has increased travelling distances without ensuring that there is an adequate mix of jobs, amenities and services in every area. This is exacerbated by the attitude of city authorities to slums: to refrain from declaring areas as slums (this entitles slums to protection from eviction and access to basic services) ${ }^{17}$ in order to routinely evict and resettle them-often ironically for transport projects-thus breaking the slum-dwellers' social and economic linkages with the land. Given that women travel shorter distances, resettlement impacts and alters their lives more than that of men.

\section{Mainstreaming gender in transport research and policy}

It is not surprising that studies of gender in transport are rarely used as input for transport planning in India, given that traditional views hold that women ought to travel only close to 
home or not at all. As this study shows, women from less affluent households are reliant on walking and on public transport. The state of repair of pedestrian infrastructure: pavements, the lack of shading, broad roads with fast traffic, lonely subways or skywalks or inadequate street lighting thus affects poor women the most and influences their decision to travel. In Bengaluru, as in other Indian cities, little attention is given to infrastructure for non-motorised transport.

A key issue is the attitudes of authorities to the urban poor. As land rates in the core areas of cities rise, slums in these areas are evicted and resettled on the periphery of the city. The negative impact of this on slum-dwellers is incalculable: conditions in the resettled slum surveyed in this study were significantly different from that of the others, in the average distances travelled, travel costs incurred and modes relied on. It is important to note that the urban poor and slums are crucial to the functioning of the city around them. They act as lowincome housing, serve the area that they are in and use space and resources efficiently.

\section{Endnotes}

1 Todd Litman, “Evaluating Accessibility for Transportation Planning”, Victoria Transport Policy Institute, 2012, esp. 3.

${ }^{2}$ Caren Levy, "Travel choice reframed: 'deep distribution' and gender in urban transport", Environment and Urbanization, 2013, Vol 25(1), 47-63, esp. 48.

${ }^{3}$ Ananya Roy, "Gender, Poverty, and Transportation in the Developing World", 2009, Conference Proceedings 46, Summary of the fourth International Conference on Women's Issues in Transportation, Volume 1: Conference Overview and Plenary Papers, 50-62, esp. 55. ${ }^{4}$ A. Church, M. Frost, K. Sullivan, "Transport and social exclusion in London", Transport Policy 7 (2000), 195- 205, esp. 197.

${ }^{5}$ Deborah Salon and Sumila Gulyani, "Mobility, Poverty, and Gender: Travel 'Choices' of Slum Residents in Nairobi, Kenya", Transport Reviews, 30:5, 641-657, First published on: 20 April 2010, esp. 643.

${ }^{6}$ Hoai Anh Tran and Ann Schlyter, "Gender and class in urban transport: the cases of Xian and Hanoi",

Environment and Urbanization, 2010, Vol. 22, 139-155, esp. 150.

7 Levy, "Travel choice reframed: 'deep distribution' and gender in urban transport", 49.

${ }^{8}$ Kelly Clifton, "Examining Travel Choices of Low-Income Populations: Issues, Methods, and New Approaches", Moving through Nets: The Physical and Social Dimensions of Travel, Session 1.1, 10th International Conference on Travel Behaviour Research Lucerne, 10-15 August 2003.

9 Roy, "Gender, Poverty, and Transportation in the Developing World", 52.

10 Gina Porter "Transport planning in sub-Saharan Africa II: putting gender into mobility and transport planning in Africa", Progress in Development Studies 8, 3 (2008) 281-289, esp. 281.

${ }^{11}$ Kerry Hamilton and Linda Jenkins, "A Gender Audit for Public Transport: A New Policy Tool in the Tackling of Social Exclusion", Urban Studies, 2000, Vol. 37, No. 10, 1793-1800, esp. 1797. 
${ }^{12}$ Anand and Tiwari, "A Gendered Perspective of the Shelter-Transport-Livelihood Link: The Case of Poor

Women in Delhi", 78.

${ }^{13}$ Jeff Turner and Philip Fouracre, "Women and transport in developing countries", Transport Reviews, 1995, Vol. 15, No.1, 77-96, esp. 88.

${ }^{14}$ RITES Ltd, Chapter 3 - "Existing Traffic and Travel Characteristics", Comprehensive Traffic \& Transportation Plan for Bangalore, 2007.

${ }^{15}$ G. S. Sastry “Emerging Development Issues of Greater Bangalore”, Working Paper 194, Institute for Social and Economic Change, 2008, esp. 5.

${ }^{16}$ Benoit Lefevre, “Long-term energy consumptions of urban transportation: A prospective simulation of

Transport-Land uses Policies", Energy Policy, Vol. 37, No. 3, 940-953, esp. 941.

${ }^{17}$ Hans Schenk, "Bangalore: an outline", 39-46 in Living in India's Slums, ed. Hans Schenk, published as part of the Indo-Dutch Programme on Alternatives in Development, 2001 


\section{Consumption and waste metabolism: Determinant changes in consumption patterns impact the generation of solid waste in the Peri-Urban areas of Quito}

Adriana Mejía Artieda; FLACSO, Ecuador

\section{Introduction}

Management of solid waste has become a challenge for Latin American cities. In most cases this problem has not been handled in an integrated way to the urban and social metabolism. The objective of this investigation is to study the influence of urban metabolism on peri-urban and rural areas close to the city of Quito. The effects of the last phases of social metabolism, consumption and excretion give rise to environmental impacts beyond where they were generated, but it is precise to know how they affect these close areas. In Ecuador, for example, very few cities have managed to generate adequate solid waste management processes. But Quito, the capital, is not one of them. Consequently, the following research question is posed: how have the patterns of consumption and generation of solid waste in the city influenced peri-urban areas? It handles the following hypothesis: sociocultural and economic determinants, such as patterns of consumption, have led to the increasing generation of solid waste in urban areas affecting the peri-urban and rural areas because of the location of the final disposition of municipal solid waste.

\section{Theoretical framework}

It is necessary to revise the notion of 'metabolic fracture', a term devised by Marx (1862). The author, after studying Liebig and Schonbein, developed an analysis based on agriculture chemistry. Karl Marx mentions that 'The systemic[...] capitalist exploitation (in the sense of theft that does not conserve the reproduction medium) of the Soil' (Bellamy, 2000, 240)'

In this sense, Liebig mentions that the methods of intense agriculture where a method of theft, on the one hand long-distance transportation from farms to cities deplete necessary nutrients like phosphorus, nitrogen and potassium, extracted from rural soils during production; and on the other hand, this depletion contributed to urban contamination in the form of organic waste and other types of urban waste. For this reason, Marx mentions that capitalism has caused an 'un-repairable breach' in the metabolic interaction between humans and the Earth (Bellamy, 2002).

The concept of social metabolism analyses the intrinsic relationship between society and nature, since the organisation of human beings determines the environment, as it transforms and affects it (González and Toledo 2005). Urban metabolism presents higher levels of consumption and excretion because the needs of societies are based on consumption and subsequently excretion, which is tied to cultural, socioeconomic or production patterns (Martínez Alier, 2001). 
Analysing urban metabolism allows us to observe the city as an open flows system. The same that enter the cities in the form of water, food or fuel and after transformation are expelled from cities in the form of wastewater, solid waste or gases. Finally, urban areas must use more energy to remove externalities from their habitable borders. Even recycling processes demand an energy income that will release gases into the atmosphere. All of this allows us to confirm the high intensity of urban metabolism (Zaman and Lehmann, 2011, Delgado, 2012). Jean Baudrillard (2009) brought critical arguments about consumption; he mentioned that what we consume are signs and symbols rather than material goods, this means that real goods are replaced by stimulations and simulations, so a new reality is created. Garbage is the final result of consumption. It demonstrates the variety of values and merchandise that exist but also reflects the 'irresponsible way that the market educates us and makes us consume, to use and litter without any limit' (Barreda, 2017 in: Kozlik, 1973; Viale, 1994; Packard 1961). A literature study shows that there is a tight relationship between waste generation, consumption of resources and uncontrolled urban growth. It also shows the existence of a symmetric relation between type and level of consumption and different socioeconomic strata, given that high consumption is associated with higher levels of economic achievement (Lehmann y Zaman, 2011, ECCO DMQ 2011)

\section{Methodology}

Methodologically the research analyses databases of the main public companies which have solid waste management in the city under their responsibility, as well as in-depth interviews and historical reviews of the main actors and decision makers of the past administrations. It also analyses the perception of inhabitants of the affected regions where the dump yard is located.

\section{Summary of case study}

The current garbage crisis has been increasing and the factors that have unleashed it have not been part of measures, actions or policies to control or prevent it. According to United Nations Environment Programme (2017) figures, the generation of solid waste in Latin America and the Caribbean reached 5,40,000 tons per day.

In this way, the placement of garbage landfills defines rural and urban territories with harmful uses of soil that are classistically imposed against marginalised people, peasants or indigenous people (Barreda, 2017, Harvey, 2013). The capitalism of waste and consumerism promotes scenarios of supposed well-being within megacities that concentrate millions of people who grow without limit in all regions of the planet (Barreda, 2017).

The Ecuadorian population in the urban sector produces an average of 0.57 kilograms of solid waste per day. In the case of Quito, the city produces two thousand tons $(\mathrm{t})$ of garbage per day. The cost of collection exceeds $\$ 500,000$ per month (El Telégrafo, 2015). It is estimated that on average 3,600 cubic meters of leachate are generated from 47,500 monthly tons of 
garbage (Solíz, 2016). Quito has transformed its management of solid waste through the years, however open dump yards or sanitary landfills have always been imposed on rural, small and indigenous communities in peri-urban areas (Solíz, 2017).

Harvey (2013) points out that under capitalism the search for surplus value has transformed urban geography along with its quality of life into a commodity, in a place where economic resources prevail and where the city is designed to facilitate the accumulation of capital. For this reason, garbage is an issue that decreases the circulation of capital by representing environmental liabilities that reduces the value of land. The structure of the city should locate landfills where they do not interfere with the accumulation of economic resources and where they do not contribute to land value loss.

In the case of Quito, dumps are located or planned in the city limits, on communal land, mostly of indigenous origin where the value of the land cannot be speculated due to regulations that theoretically prevent it. Barreda (2017) in 'trash and magical thinking' refers to the way we perceive waste that we generate daily in cities. The use of garbage management systems or use of toilets connected to a sewage water system, allows citizens not to pay attention to the generated waste because they "magically disappear" thanks to many factors, be they economic, modern municipal cleaning infrastructures, or technological among others.

According to Solíz (2016), the term 'residue' is understood as: 'the result of the metabolic relationship between society and nature'. The category of 'metabolic fracture field-city' is essential to analyse the social metabolism in political ecology and for Solíz this category is essential for the 'construction of a critical theory of waste'. In the case of the city of Quito, which produces 2,000 tons of garbage daily and whose destinations are transfer centres and sanitary landfills far from the city in communal lands and indigenous territories, we see that what returns to the field is not organic matter to replenish the soil, but what returns to the field is toxic matter that is deposited in dumps or 'sanitary engineering' (Solíz, 2016).

\section{Conclusions}

Urban consumption patterns materialised in the growing generation of solid waste, have an environmental influence on the peri-urban and rural sectors of the city of Quito. Waste management in Quito has been transformed in the last 20 years, however, it has not evolved in terms of environmental responsibility or efficiency nor has it tried to repair this metabolic rupture between the countryside and urban areas. The dumps, landfills and transfer centres of the city have been historically located and planned in indigenous territories or communal land, affecting the lives of people who already inhabit those areas. Additionally, they are close to agricultural areas and rivers that provide water to the city itself, so the damage could become irreparable. 


\section{End Notes}

'The term 'metabolism' (Stoffwechsel) was introduced in 1815 by German physiologists. The same was used to refer to respiration; for its wide significance in 1842 Liebig used it in animal chemistry (Bellamy, 2000, p.246-247).

\section{References}

Alier, J. M., \& Jusmet, J. R. (2001). Economía ecológica y política ambiental. [Ecological economics and environmental policy] México: Fondo de Cultura Económica.

Barreda, A. (2017). Economía Política de la Actual Basura Neoliberal, en Ecología política de la basura. Abya-Yala, Quito: Pensando los Residuos desde el Sur.

Baudrillard, J. (2009). El sistema de los objetos [The system of objects]. México: Siglo XXI de España Editores S.A.

Bellamy, F. J. (2000). La ecología de Marx: Materialismo y naturaleza [Marx's Ecology: Materialism and Nature]. Madrid: Ediciones de intervención Cultural El Viejo Topo, España.

Delgado, G. C., Campos Chávez, C., \& Renterí-a Juárez, P. (2012). Cambio climático y el metabolismo urbano de las Megaurbes Latinoamericanas [Climate change and the urban metabolism of the Latin American Megaurbes]. Hábitat Sustentable, 2(1), 2-25.

Harvey, D. (2013). Ciudades rebeldes: Del derecho de la ciudad a la revolución urbana. [Rebel cities: From the right to the city to the urban revolution] Madariaga, Juanmari, Madrid: Ediciones Akal.

ONU Ambiente. (2017, November 21). Aumenta la generación de residuos en América Latina y el Caribe mientras 145.000 toneladas aún se disponen de forma inadecuada cada día [Increases waste generation in Latin America and the Caribbean while 145,000 tonnes are still inadequately disposed of each day]. unenvironment.org. Retrieved from https://www.unenvironment.org/es/news-and-stories/reportajes/aumenta-lageneracion-de-residuos-en-america-latina-y-el-caribe

PNUMA. (2011). Perspectivas del ambiente y cambio climático en el medio urbano: ECCO Distrito Metropolitano de Quito [Perspectives of the environment and climate change in the urban environment: ECCO Metropolitan District of Quito]. Quito: Sede Ecuador.

Quito Editorial Board. (2015, September 6). Quito recicla 640 toneladas de basura al mes [Quito recycles 640 tons of garbage per month]. El Telégrafo. Retrieved from https://www.eltelegrafo.com.ec/noticias/quito/11/quito-recicla-640-toneladas-debasura-al-mes

Solíz, T., \& Fernanda, M. (2016). Salud colectiva y ecología política: la basura en Ecuador [Collective health and political ecology: Garbage in Ecuador] Quito: Universidad Andina Simón Bolívar, Sede Ecuador.

Solíz, T. M. F. (2017). Por qué un Ecologismo popular de la Basura? [Why a Popular Ecology of garbage]. En M. F. Solíz,. Ecología política de la basura Pensando los residuos desde el Sur (pp. 19-50). Quito: Abyayala.

Toledo, V. M., \& de Molina, M. G. (2005). El metabolismo social: las relaciones entre la sociedad y la naturaleza [The social metabolism the relations between society and 
nature].En F. Garrido Peña, M. G. de Molina, J. L. Serrano Moreno, J. L. Solana Ruiz (Eds.), El paradigma ecológico en las Ciencias Sociales (pp. 85-112). Barcelona: Barcelona Prensa.

Zaman, A. U., \& Lehmann,S. (2011). Challenges and opportunities in transforming a city into a zero waste city. Challenges, 2(4), 73-93. 


\section{Symbiosis or parasitism? Exploring the city-region relationship through the support capacity}

Oscar Mejía-Rivera, Carlos Cadena-Gaitán, Santiago Mejía-Dugand; Universidad EAFIT

\section{Introduction}

The city offers its inhabitants the illusion of self-sufficiency, of independence. This is, to a great extent, thanks to technology, which is one of its main attributes (Gandy, 2005). Modern technology hides the origin and destination of resources and waste: many city dwellers have little idea of where the water they drink comes from, where the energy they use is generated, and where their waste is disposed of. Nevertheless, it has not always been the case.

Throughout history, most humans have been aware of this, considering that they had to search, collect and transport water for their consumption, collect biomass to cover their energy needs, and get rid of their wastes by themselves. All of this took a significant portion of their time and usually meant great effort.

However, a growing population cannot domestically solve the need to access resources for all, and this has had an impact on how urbanites live, consume, and dispose of their waste: urbanisation also means changing cultures and the relations of city inhabitants with space and common-pool resources (Uribe and Valencia, 2005). Natural constraints were overcome: access to water was no longer conditioned to the location of water basins and food was no longer conditioned to geographic proximity, the city's reach no longer limited by its enclosing walls, and mobility no longer subject to the traditional slow means (Urbam, 2018).

Public services such as drinking water, energy and sanitation are today inevitable components of city life. In fact, Uribe and Valencia (2005) claim that in poor and developing countries, utilities are a symbol of insertion into the city, especially for those immigrants fleeing violence in the countryside or looking for better economic opportunities and settling in self-built neighborhoods in the periphery of cities. In addition, as cities become entrepreneurial, expanding coverage is not only a matter of outreach, but also a deliberate action to generate financial resources (see e.g. Mejía-Dugand et al., 2017).

All of this usually comes with a great toll on the environment, both locally and regionally. The environmental impact caused by city life in general, and the provision of utilities in particular, is usually hidden, especially considering that the main objective has been to meet human needs, and not sustainability (Montoya, Brand, 2005). Although the gap between urban public utilities and the environment is filled shallowly by the notion of finiteness implicit in terms such as 'renewable energy,' 'cleaner production,' and 'biodegradable waste', these services are seldom associated with the environment (cf. 'eco-utilities') (Montoya-Brand, 2005). The interaction between cities and their surrounding regions takes different shapes: ecological, socioeconomic, cultural, and institutional. Complementarity and dependence links transcend political and administrative limits which require a systemic approach for planning and public policy purposes (Urbam, 2018). 


\section{Modelling support capacity through Densurbam}

Keeping in mind the need to better understand the relations between the city and its surrounding environment, the research group has developed a mathematical model called Densurbam. The objective is to offer a tool that makes it possible to identify the support capacity of a municipality or area, with neighborhoods as units of analysis. The model's central variable is population, and the objective is to evaluate the impact that population growth has on the supply of resources and infrastructure, and their relation with land-use planning. The model is based on a supply/demand analysis, which should be the fundamental variable to plan for growth. However, it has been systematically missed by numerous land-use planning attempts (Urbam, 2018). Projected urban population growth has been based on master land-use plans, which is why cities constantly exceed the physical limits imposed by the urban-environmental system. Knowing how large a population a certain area can maintain is a crucial consideration to plan for sustainable cities and regions. For this, it is crucial to identify which are the limiting factors.

Although Densurbam is a mathematical model, it suggests a graphical approach to make it easier to understand how limiting factors have an impact on population growth. For this, it uses a graph to explain how, despite the availability of all the nutrients a plant needs to grow, it is the scarcest nutrient - the one limiting its growth. This graph is called Liebig's barrel (see Liebig, 1845). Each stage of the barrel represents a nutrient, and the capacity of the barrel to contain a liquid (in terms of the liquid's height) is determined by the shortest stave. This is the limiting factor.

Densurbam suggests three categories that encompass different variables that can be analysed in the search for limiting factors:

(i) Ecosystem health and resilience; can include variables such as PM2.5 emissions, BOD, subterranean water, and forest cover.

(ii) Resource availability; can include variables such as availability of drinking water, habitable land, or construction materials.

(iii) Social development skills; can include variables such as transport's modal share, water consumption, waste production, and population density.

\section{Support capacity is not necessarily a fixed value}

Support capacity is not static, but dynamic, which means that it can change by recognising and managing the limiting factors (Urbam, 2018). Densurbam allows for the modelling of the behavior of a region's support capacity as different variables change in time. It allows simulating different population growth scenarios and growth's effect on urban/environmental systems. In particular, the model allows for the analysis that behavioral changes could have on a certain region's support capacity, i.e. land use and consumption patterns, which is referred to as 'social development skills'.

Also among the social development skills is civic culture, which is considered as one of the main pillars of the model. Densurbam aims to demonstrate that educational strategies and 
initiatives that promote, for instance less consumption and recycling activities, could result in more far-reaching results when it comes to the sustainability of infrastructure, the city, and the region it depends on for its survival.

\section{Applying the Densurbam model to the metropolitan area of the Aburrá Valley, Colombia.}

Life in modern cities is closely connected to life in the nearby and remote regions. With this in mind, it is necessary to redefine the relation that cities have with the surrounding regions, since its metabolism is dependent on them (Urbam, 2018). Due to the rapid growth that the region's capital city (i.e. Medellín) had during its industrialisation phase in the beginning of the twentieth century, and the conurbation that resulted from its proximity to the surrounding municipalities, the Área Metropolitana del Vallé de Aburrá [Metropolitan Area of the Aburrá Valley] (AMVA) institution was created to administer the integration. By law, cities with more than one million inhabitants must have a metropolitan environmental authority. Other, less populated cities are administered by regional environmental authorities. As of 2018, Medellín and its metropolitan area (which is composed of nine other municipalities) was inhabited by nearly four million people (Urbam, 2018).

Densurbam is built on three main pillars: metropolitan integration, regional interdependence, and quantitative language as a management tool (Urbam, 2018). Its operationalisation rests on the analysis of three different factors: (i) socioeconomic dependence, which refers to cultural, political and professional links among the ten municipalities composing AMVA; (ii) ecological dependence, related to ecosystem services such as the provision of drinking water, motive power, the provision of food, and carbon capture; and (iii) functional dependence, or the reliance on large technical systems that transcend municipal barriers and supply services such as waste disposal, fuel transport, mobility and transport, and logistics centers.

\section{Objectives}

The main objectives of this paper are:
a) Suggest the modelling of support capacity to better understand the relations of the city with its surrounding region.
b) Present Densurbam as a support capacity model.
c) Suggest the analysis of support capacity as an inevitable resource to build master zoning plans and control for variables such as population density.
d) Show the applicability of the Densurbam model to a city and its surrounding region.




\section{References}

Gandy, M. (2005). Cyborg urbanization: Complexity and monstrosity in the contemporary city. International Journal of Urban and Regional Research, 29(1), 26-49.

https://doi.org/10.1111/j.1468-2427.2005.00568.x

Liebig, J. (1845). Química orgánica aplicada a la fisiología animal y a la patología [Organic chemistry applied to animal physiology and to pathology]. Imprenta de la Sociedad de la Revista Médica.

Mejia-Dugand, S., Hjelm, O., \& Baas, L. (2017). Public utility companies in liberalized marketsThe impact of management models on local and regional sustainability. Utilities Policy, 49, 137-144. https://doi.org/10.1016/j.jup.2017.05.002

Montoya-Brand, M. A. (2005). Servicios públicos domiciliarios y pensamiento ambiental: una aproximacion [Household public utilities and environmental thinking: an approximation]. Letras Jurídicas, 10(1), 143-186.

URBAM. (2018). Capacidades de soporte urbano- ambientales para el territorio metropolitano del Valle de Aburrá - Densurbam [Urban- environmental support capacities for the metropolitan region of the Aburrá Valley - Densurbam]. Medellin: urbam EAFIT.

Uribe, M. T., \& Valencia, G. (2005). Tensiones y dilemas en la prestación de los servicios públicos domiciliarios en Colombia: entre lo público, lo privado y lo estatal [Tensions and dilemmas in the provision of household public services in Colombia: among the public, the private and the State's]. Letras Jurídicas, 10(1), 31-76. 


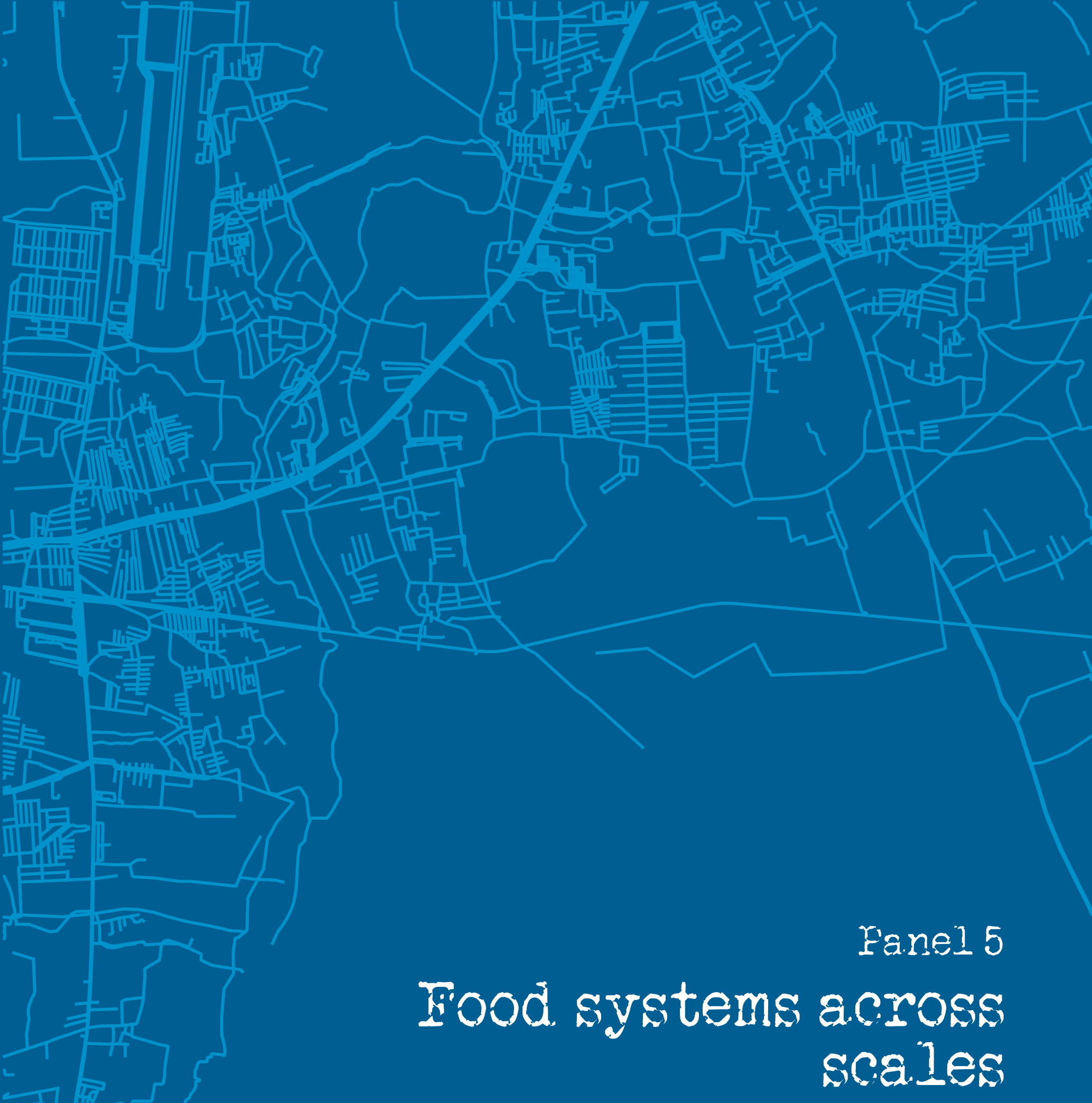




\section{Panel Abstract}

Much of the scholarship on food systems describes it as entailing the gamut of production, supply, distribution, retailing, consumption, material culture and social reproduction (Bohle, 1994; Fine, 1995). These formulations however only nominally appear in research. A significant portion of food systems research derives instead from classical formulations of the agrarian question, is focused on the rural, and largely on the role of local agriculture in contributing to food security (Goodman, 2002). Consumption appears in the form of a finished product, subject to demand. The linkage between the two is scarcely accounted for (Whatmore, 2002; Lockie \& Kitto, 2000). Newer, specifically urban framings of the food question swings between a focus on urban agriculture or more distribution and consumption oriented concerns, when in fact urban food systems are equally shaped by transportation, energy use, environment and public health (Pothukuchi \& Kaufman, 1999). A dichotomous understanding of urban and rural fails to hold within food systems given their interdependence, a phenomenon attenuated by climate change's effects potentially simultaneous effects on food production, supply, delivery and distribution (Vermeulen, Campbell, \& Ingram, 2012) with implications for food prices (Tacoli, Budoor, \& Fisher, 2013) and access. The ontological and operational separation of urban policy from agriculture (an activity that takes a distinctly rural form in the planning imaginary) has also meant a separation of natural resource management from urban spaces (Baker \& de Zeeuw, 2015).

Common to these disparate framings has been a fragmented conceptualisation of how these elements fit into a food system conceptualised as a whole, including people, processes and plants on an equal plane, as well as accounting for the multiple scales across which these systems operate.

A way out of this conundrum is offered by the scholarship on regional food systems which argues that we cannot dissociate the urban from the region, need to connect the local with the regional, national and global (Bohle, 1994). Bohle \& Guyer (1987) to propose a "regional social history" approach to food system analysis, making important points about considering scale, space, society and history. Feenstra (1997) also advocates for a regional approach, that entails looking at the historical patterns of agricultural production in the area, dependency on outside sources of food, urban agriculture as well as policy processes and institutions. More recent work has also noted the imperative of linking food systems across multiple scales, including the national and the global (Goodman, 2002).

This panel is oriented towards bridging both traditionally "rural" and "urban" concerns, that is attentive to historical and temporal patterns, accounts for the cross-functioning of sectors such as agriculture, trade, environment, development interventions and governance to name a few, and is mindful of place-specificities as well as the people, animals and things that inhabit them. All three papers overlap in the location of their work across different kinds of 
areas - rural, peri-urban and urban, as well in their insistence about the co-production of these spaces.

The challenge remains to draw different actors and practices into a coherent framework with which to understand how food systems are constituted and evolve, allowing for what Callon (1986) calls a "radical symmetry" of human and non-human entities, privileging networks of differently constituted actors, and at the same time linking seemingly distant global networks in local action. This is based on the conceptual premise that an understanding of urban food networks that does not recognise their embedding in local, regional, national and global scales would fail to account for their inter-connectedness (Bohle, 1994; Feenstra, 1997).

Adopting such a framework has specific implications for research conceptualisation and practice. In rural areas for example, we imagine the food question to include not just questions of growing of crops or even more classical questions of the relations of production, but to expand outwards from the traditional agrarian question to new paradigms of production practice and technology, land grabs, the financialisation of agro-food chains across scales, and their changing forms to name a few. Similarly, the urban food question is often represented as being that of urban agriculture or of consolidation of corporate power through the supermarketisation phenomenon or alternately one of unequal consumption patterns of produced goods. Instead we suggest a wider agenda, that includes but is not limited to themes such as the changing nature of supply chains in the face of new forms of commerce entities, the increasing branding and consumption of "local" and "organic" food through subjective and affect-oriented business strategies, the greening of urban spaces through urban farms and gardens, the dispossession of farmers from these green spaces, changing practices of production on the periphery deriving from changing land use patterns, changing diets and inequalities in access amongst others. We especially suggest a focus on areas denoted as being peri-urban, for the mix of elements they offer. The three papers included in this proposed panel address these specific concerns.

The first paper "Small Farms around Bengaluru - Growing at the Cost of Food and the Environment by Sheetal Patil, Seema Purushothaman, Raghvendra Vanjari, Dhanya B and Shwetha A R examines how changing agrarian ecologies in the peripheries of Bangalore shape market chains that cut through the city. The authors use three examples - that of lawn grass cultivation, high value floriculture and eucalyptus plantations to demonstrate how choices of crops are shaped by the differently located privileges of farmers, as well as the monetary incentives that drive them. The growing of these crops change social relations as well as market networks in different regions as well as at different scales. In the case of eucalyptus plantations, while eucalyptus trees are easy to grow, it is precisely this fact that allows landowners to maintain limited connections with the land and the social systems in which agrarian practices are embedded, while simultaneously reaping great profits. The primary interest of landowners in growing eucalyptus is to allow themselves to hedge their bets, holding off on selling land in a growing real estate market while still profiting from it. 
This consequently means that groundwater exploitation, declining crop diversity and yields, and falling biodiversity emerge as challenges in the area. Linked concerns emerge from an expanding area under floriculture, where an increasing demand from urban consumers for flowers and lucrative nature of flower markets has meant that cropping patterns are changing, with implications for the changing nature of agrarian landscapes and food security.

The second paper Remaking Town and Hinterland: Reshaping Palates and Transforming Diets in Western Awadh, Uttar Pradesh, India by Richa Kumar, Richa Singh, Sudha Nagavarapu and Surbala Vaish draws from research in Sitapur in the Western Awadh region of Uttar Pradesh and around it to demonstrate how crop production patterns and palate preferences are mutually constituted across regions and scales. The paper demonstrates how over time, the area around Sitapur shifted from a historically groundnut and gur producing economy to a sugar dominated area, deriving from the privileging of sugar mills and the production of white sugar in the market economy. These changes were bolstered by changing agricultural practices such as the use of borewells for the water-intensive crops as well as a Minimum Support Price-based procurement regime that allowed farmers to make significant profits. The provision of sugar through the PDS as well as a general shift in preferences towards white sugar that signified an upward mobility meant that changing palates shaped the changing significance of Sitapur's village economy.

These changes are not specific to the sugar industry, but are indicative of wider shifts in consumption and production patterns in other formerly prevalent crops such as millets, lentils, cereals, etc across caste, class and regional groups.

The third paper The Data of Food: E-Commerce Business to Business Firms and their Shaping of Food Supply Chains in Karnataka by Natasha S.K., Shwetha Govindan and Keerthana Jagadeesh is a study of e-commerce Business to Business (B2B) firms in Bangalore that intervene in food supply chains to eliminate middlemen and ostensibly help farmers realise profits. These B2B firms are built on networks of capital, labour and technology that hinge on a multiplicity of beliefs with respect to how markets function, as well as standardisation, quality and price. By claiming to circumvent government institutions, these firms themselves form alternate structures of governance, attempting to rework the existing institutional space and carve out a share for themselves. Their ability to do so is partially circumvented by the nature of markets that persist as "informal" yet resilient, fragmented yet widespread, and citybased yet deeply connected with the hinterlands. And yet, through their ability to command vast amounts of data, mobilise significant sets of resources, and alter networks, these firms are changing the rules of the game. 


\section{References}

Baker, L., \& de Zeeuw, H. (2015). Urban food policies and programmes: an overview. In Cities and Agriculture (pp. 44-73). Routledge.

Bohle, H.-G. (1994a). Metropolitan Food Systems in Developing Countries: The Perspective of " Urban Metabolism " Author ( s ): Hans-Georg Bohle Source: GeoJournal , Vol . 34 , No . 3 , Cities of Hunger: Urban Food Systems in Developing Countries ( November 1994 ), pp . 245-. GeoJournal, 34(3), 245-251.

Bohle, H.-G. (1994b). Metropolitan food systems in developing countries: The perspective of ?Urban Metabolism? GeoJournal, 34(3), 245-251. https://doi.org/10.1007/BF00813926

Callon, M. (1986). Some elements of a sociology of translation: domestication of the scallops and the fishermen of St. Brieuc Bay. In J. Law (Ed.), Power, action, and belief: A new sociology of knowledge? (London: (pp. 196-229). London: Routledge and Kegan Paul.

Feenstra, G. W. (1997). Local food systems and sustainable communities. American Journal of Alternative Agriculture, 12(01), 28. https://doi.org/10.1017/S0889189300007165

Fine, B. (1995). From political economy to consumption. In D. Miller (Ed.), Acknowledging consumption: A review of new studies (pp. 127-163). London: Routledge.

Goodman, D. (2002). Rethinking food production-consumption: Integrative perspectives. Sociologia Ruralis, 42(4), 271-277. https://doi.org/10.1111/1467-9523.00216

Guyer, J. I. (1987). Feeding African Cities. Manchester: Manchester University Press.

Lockie, S., \& Kitto, S. (2000). Beyond the farm gate: Production-consumption networks and agri-food research. Sociologia Ruralis, 40(1), 3-19. https://doi.org/10.1111/1467-

9523.00128

Pothukuchi, K., \& Kaufman, J. L. (1999). Placing the food system on the urban agenda: The role of municipal institutions in food systems planning. Agriculture and Human Values, 16(2), 213-224. https://doi.org/10.1023/A:1007558805953

Tacoli, C., Fisher, S., \& Budoor, B. (2013). Urban poverty, food security and climate change.

Vermeulen, S. J., Campbell, B. M., \& Ingram, J. S. (2012). Climate change and food systems. Annual review of environment and resources, 37, 195-222.

https://doi.org/10.1146/annurev-environ-020411-130608

Whatmore, S. (2002). Hybrid Geographies. London: Sage. 


\section{Small farms around Bengaluru: Growing money at the cost of food and environment}

Sheetal Patil, Seema Purushothaman, Raghvendra Vanjari, Dhanya B and Shwetha A R; Azim Premji University, Bengaluru, Karnataka, India

Urbanisation, along with becoming a universal trend, has also emerged as a significant driver of agricultural transition in the developing world. More and more people from rural parts of India migrate to urban centers in search of non-farm livelihood options and for better living conditions. Urbanisation is closely coupled with transformation of traditional rural economies into modern industrial economies through irreversible land use change. The land remaining under farming is also influenced by urban demand with mixed outcomes in production and livelihoods. India exhibits this reciprocity of urbanisation and farming prominently.

One major outcome of this reciprocity between cities and farming is that contribution of the primary sector to GDP at current prices declined from 23.3 per cent in 2001 to 17.3 per cent in 2016, though 60 per cent of the total workforce remained dependent on farming as a primary occupation. Another outcome of the above mentioned reciprocity is how peri-urban farming behaves differently from the rest. Varied stressors of urban origin like growing demand for land and exotic commodities, together with constraints in inputs including water and labour, drive peri-urban farming in unanticipated directions. Bengaluru, India's technology hub and home to nearly ten million inhabitants, is a case in point. Commercial, industrial and residential constructions, air and water pollution, and landscape fragmentation in and around this city have greatly transformed farming practices and systems in its surroundings. This paper looks at specific transitions in the production ecology of agrarian peripheries around Bengaluru.

Moving from locally or regionally integrated farming systems and tending towards globally linked value chains, these altered agricultural systems impact multi-functionality [e.g. economic, social and environmental functions (Pretty, 2008)], diversity [e.g. including crops for food, fibre and fuel (King, 2014)] and resilience [e.g. with agro-ecological considerations that ensures sustainability (Altieri, et al 2012)] of family farming. Dietary preferences, gender relations, social connectedness and inclusivity are also reshaped in these new farming practices, through a mosaic of dynamic linkages between the city and its peripheries. In periurban areas with new farming systems market network and value chains also get transformed.

Case studies of growing lawn grass, eucalyptus trees and high value flowers around Bengaluru are used to depict agrarian changes in peri-urban Bengaluru.

(a) Lawn grass cultivation: New kinds of urbanism with its roots and shoots in global cities stipulate 'greenery' as integral to its built-up environment. Greenery here means manicured 
lawns and exotic plants around. Lawn grass cultivation and nurseries for ornamental plants take up land from staple and other food crops in huge extents of land in peri-urban Bengaluru. Lawn grass cultivation demands generous application of synthetic inputs and water. Sods of lawn grass are harvested every three to four months as green sheets along with half-an-inch of top soil underneath. Thus it demands for soil replenishment using soil purchased either from lake beds or excavations at construction sites or fallows in nearby areas.

The harvested sods are sold to local traders who further sell it to other traders from major cities of South India. Lawn grass, giving nearly three harvests each year and a net income of ₹ 2 to 3 lakhs from an acre with every harvest, could be an ideal candidate if immediate farm income is the only concern of both, the land owner and cultivator, and the government. Soil deterioration and ground water depletion as well as weakening community fabric might indicate differently. Customary sharing of labour, farm animals, manure and even harvest turn to be things of the past. Individualisation and farming exclusively for profit also comes at a cost of nutritional security in the locality.

b) Eucalyptus plantations: Amidst widespread concern over deforestation, fast growing eucalyptus trees were introduced around Bengaluru during 1950s as a greening effort, by the Forest Department on degraded hillsides. Later on it rapidly spread to farm lands as well from 1980s, following a project aided by the World Bank to generate fuel wood and timber for communities.

Other reasons for eucalyptus trees to spread included the fact that a hybrid variety of eucalyptus starts yielding poles within six-seven years. Labour scarcity for regular farm works, water insufficiency for raising crops for the city and assured demand for timber, poles and twigs from the tree as well as the potential to extract and sell essential oils from its leaves also contributed to its spreading. Demand from pulp industries and the construction industry booming in Bengaluru for scaffolding were greatly instrumental in its spread into individual smaller farm lands. The average net income per acre from eucalyptus came to ₹ 1,00,000 annually from the third to fifth year of planting, depending on the harvest of poles or timber.

Still, it was mostly the choice for absentee farmers who wouldn't need staples to be cultivated. Choosing a tree that will demand least inputs and management while yielding some cash income made sense outside an expanding city, where land owners waited for good real estate deals. Some farmers without irrigation converted their entire land into eucalyptus plantation and worked as wage labour in their own village or nearby suburban areas. Locally known as nilgiri, spreading widely in agricultural fallows, eucalyptus implies absentee landlordism and de-peasantisation. Ground water depletion (Srivastava, et al 2003), soil erosion (Thompson, 2016), declining crop diversity, birds (Phifer, et al 2016) and insects (Diniz, et al 2010) are observed in and around eucalyptus groves. 
(c) Cut flowers in poly-houses: Bengaluru's image as 'Garden City' with thriving horticultural research and activities makes it a hub for flower trade. The international flower auction centre set up in 2002, gave impetus to intensive export oriented floriculture around the city. Exotic high value flowers for urbanites in and outside Bengaluru are generally grown in poly-houses. Dependence on skilled labour often from Uttar Pradesh and Bihar, use of high-cost agrochemical inputs, equipment and technology for growing, harvesting, marketing, packing and transporting makes it more of a business that requires good amounts of initial investment and operational costs, than agriculture.

The annual net return comes to $₹ 7-8,00,000$ from an acre. Farmers seemed to know that in five-to-six years of this kind of intensive cultivation, soil and water would be depleted. Polyhouse floriculture, as in the two cases above, has tradeoffs with food crops, in addition to the externalities in terms of ground water depletion, chemical pollution of soil and water as well as occupational hazards.

Thus the opportunities that cities offer to their agrarian peripheries are harnessed by resourceful entrepreneurs. These opportunities come with considerable trade-offs unless strategised with an 'agriculture first' approach to urbanisation.

\section{References}

Pretty, J. (2007). Agricultural sustainability: concepts, principles and evidence. Philosophical Transactions of the Royal Society B: Biological Sciences, 363(1491), 447-465. https://doi.org/10.1098/rstb.2007.2163

Phifer, C. C., Knowlton, J. L., Webster, C. R., Flaspohler, D. J., \& Licata, J. A. (2017). Bird community responses to afforested eucalyptus plantations in the Argentine pampas. Biodiversity and conservation, 26(13), 3073-3101. https://doi.org/10.1007/s10531-0161126-6

Srivastava R. J., Kumar, A., \& Prasad, K. (2003). Studies on soil moisture variation under Eucalyptus plantation. Paper presented at the XII World Forestry Congress, Canada. Retrieved from http://www.fao.org/3/XII/0500-B2.htm.

Thompson, A., Davis, J. D., \& Oliphant, A. J. (2016). Surface runoff and soil erosion under eucalyptus and oak canopy. Earth Surface Processes and Landforms, 41(8), 1018-1026. https://doi.org/10.1002/esp.3881

Diniz, S., Prado, P. I., \& Lewinsohn, T. M. (2010). Species richness in natural and disturbed habitats: Asteraceae and flower-head insects (Tephritidae: Diptera). Neotropical entomology, 39(2), 163-171. http://dx.doi.org/10.1590/S1519-566X2010000200004

King, O. E., Siddick, S. A., Gopi, G., \& Kav, N. (2014). Enhancing crop diversity leads to farm resilience. LEISA India. Retrieved from https://leisaindia.org/enhancing-crop-diversityleads-to-farm-resilience/

Altieri, M. A., Funes-Monzote, F. R., \& Petersen, P. (2012). Agroecologically efficient agricultural systems for smallholder farmers: contributions to food sovereignty. Agronomy for Sustainable Development, 32(1), 1-13. http://dx.doi.org/10.1007/s13593-011-0065-6 


\section{Remaking town and hinterland: Reshaping palates and transforming diets in western Awadh, Uttar Pradesh, India}

Richa Kumar; IIT Delhi; Richa Singh, Sudha Nagavarapu, Surbala Vaish; Sangtin, Sitapur

William Cronon's book Nature's Metropolis drew attention to the simultaneous production of the city of Chicago and its hinterland-urban industrialisation driven by and driving the production of grain, lumber and meat. Drawing from Cronon's work, this paper looks at the mutual reshaping of the agro-industrial economy of western Awadh, centred on the town of Sitapur in Uttar Pradesh, and its hinterland. Tracing the history of three commoditiesgroundnut, gur and sugar-it argues that this remaking of agro-industrial landscapes also reshaped the palates and diets of people in the region, while contributing to a growing nutritional crisis in rural western Awadh.

Just after independence, Sitapur town was the heartland of a vibrant agro-industrial economy built on groundnut (moongphali) and lentil ( $d a l$ ) cultivation in the region. The bhood ilaka (sandy region) of western Awadh (spread across the districts of Sitapur, Hardoi and Lakhimpur) had just the right type of soil for groundnut to grow during the kharif season and over 200 oil expeller units in Sitapur town powered this economy. Upper caste farmers, many of them erstwhile zamindars, had storehouses full of groundnuts, and labourers from the matiyaar (low-lying) regions would trek to work in groundnut fields all through the rains.

Bullock carts laden with groundnuts would wend their way across the Gomti river and down to the town of Sitapur, destined for the mills. The oil from the mills would go into making dalda (vanaspati or hydrogenated oil). Groundnut was part of the local diet, predominantly as chabena-a sweet or salty snack made of roasted groundnuts and gur or spices. All through winter, specific caste groups would roast groundnuts in the villages and in the Sitapur town.

Today, groundnut has disappeared from plates and palates. The new chabena is rusk or biscuit and roasted groundnut that is still available in Sitapur town comes from faraway: Gujarat and Rajasthan. The oil expeller mills shut down beginning in the 1970s and the last of the village storehouses were given away at the turn of the century.

The first to come were the rice mills. Government subsidies through the levy system (purchase for the public distribution system PDS) in the 1970s and 80s led to the establishment of several rice mills in Sitapur by local merchant families from Jain and Baniya castes, many of whom were earlier running oil mills. This strengthened the relationship between the hinterland and town with the state as an important mediator between them. But in the last decade, this economy collapsed along with the farms that produced rice. The mandi in Sitapur town slowly emptied out, bereft of its grain and the financial flows that tied it together. Local merchant families found themselves at the edge of bankruptcy, overtaken by a new agro-industrial regime of sugar mills established through state subsidies and capital 
from outside the region (such as the Birlas and Dalmias). The pull of Sitapur town and its bazaar, slowly gave way to the more dispersed sugarcane economy. In the 1990s and 2000s a spate of sugar mills came up across Sitapur, Lakhimpur and Hardoi districts. These factories were not in the town but spread across the region, each with its own hinterland where it encouraged the cultivation of sugarcane through massive extension efforts and guaranteed purchase. The peculiarities of the sugarcane economy in India have been well described (Baviskar and Attwood, 1992, Breman, 1996, Attwood, 1988 among others). What is less well known is the transformation of diets that became wrought because of the sugarcane economy.

In the past sugarcane was grown in fertile patches in the bhood ilaka (sandy region) and in the matiyaar (low-lying) region. This was linked to a village-level economy of gur making. Specific caste groups travelled from village to village setting up small gur-making units for the duration of the sugarcane harvest. This gur and other byproducts of processing sugarcane locally, such as raab (a liquid drink), formed a part of the staple diet of people across caste and class. Throughout winter, gur-moonghali was the chabena of choice.

With the advent of affordable irrigation technologies such as submersible pumps and plastic pipes, the bore well became ubiquitous and supported the growth of a water guzzling crop like sugarcane. Even the bhood ilaka, which could initially support only groundnut and hardy crops like millets, became suitable for sugarcane with land levelling and bunding. The surge in sugarcane acreage came at the expense of everything else-groundnut, pulses like arhar and $u_{\mathrm{rad}}{ }^{1}$, millets and eventually, even rice and wheat! ${ }^{2}$

And the lure of the sugar mills destroyed the village gur economy. With the government guaranteeing a minimum support price for sugarcane, and the price being subject to periodic increases thanks to farmers' agitations, sugarcane became a cash cow and farmers shifted en masse towards $i^{3}$. But instead of selling it to kolhus in the village, each sugar mill became a magnet for small scale gur makers, who set shop along the highways to the mill. These kolhus working with labour from outside the region responded to market dynamics, increasing or decreasing capacity based on the supply of sugarcane. Their input catchment was the mill's overflow stock. Their output market, ironically, was not consumers of gur, but intermediaries who used gur to make alcohol. ${ }^{4}$

The impact on diets can be traced back to three intersecting factors. First, the availability of gur declined locally and gur became a marketed commodity, even for rural people. Thus, its demand was affected by purchasing power and entitlements of people. Second, state support to sugar, including public provision through the PDS, made it ubiquitously available at cheap prices. This supply story tied in with a third factor - the weakening of demand for gur and a shift towards sugar-white, 'pure', 'refined', modern—reflecting an aspirational, upwardly mobile consumer who was in with the times. ${ }^{5}$ 
The story of the groundnut and gur are symptomatic of a wider trend of transformation of diets from a diversity of millets, oilseeds, lentils, cereals, seasonal varieties of greens, milk and milk products, meats and fish in the 1960s to a polished cereal heavy fare of rice, wheat, potatoes and sugar by the 2000s, across caste and class in the hinterland of Sitapur, as well as among the urban poor.

This reshaping of palates and transformation of diets was a result of the mutual reshaping of the hinterland and town due to state sponsored and private capital abetted agricultural intensification in association with the monetisation and marketisation of certain commodities. Initially, caste-based merchant capital in the region underwrote the first shift from groundnuts to rice, thus, continuing the relationship of the town and its hinterland. But the second shift to sugarcane unhinged the town itself. The entry of corporate capital from outside the region and the characteristics of the sugarcane economy transformed the townhinterland relationship and led to the slow demise of the relevance of Sitapur to the local agrarian economy.

\section{Endnotes}

${ }^{1}$ Sitapur was also once famous for its arhar and urad dal, which were processed initially in dal ke darane (mechanical pounders) and then exported all over the country.

${ }^{2}$ Being a nine-month crop that can be harvested for two years, it affected the sowing of crops in both the kharif and the rabi season.

${ }^{3}$ Since sugarcane has to be processed as soon as it is cut (every hour of delay reduces the amount of sugar that can be recovered), farmers have pre-harvest contracts with sugar mills for their acreage. This ensures that mills get guaranteed supply, but also that farmers do not sell anywhere else.

${ }^{4}$ Brewing alcohol has become a part-time occupation at the village level with gur used as the raw material. By some informal estimates, 90 per cent of gur production is diverted towards making alcohol.

${ }^{5}$ The nutritional problems associated with the consumption of white sugar have entered public discourse only in the last two decades, with the growing epidemic of Type II diabetes.

\section{References}

Cronon, William. 1991. Nature's Metropolis: Chicago and the Great West. New York: W. W. Norton.

Attwood D.W. and B.S. Baviskar (Eds.). 1988. Who Shares? Co-operatives and Rural Development. Delhi: Oxford University Press.

Attwood, D.W. 1992. Raising cane: The political economy of sugar in western India. New Delhi: Oxford University Press.

Breman, J. 1996. Footloose labour: Working in India's informal economy. Cambridge: Cambridge University Press 


\section{The data of food: E-commerce business to business firms and their shaping of food supply chains in Karnataka}

Natasha S.K., Shwetha Govindan, Keerthana Jagadeesh; Indian Institute for Human Settlements

Though there has been an increasing body of scholarship on multiple questions surrounding the use of mobile applications, whether for food delivery, cab-hailing or online dating, backend processes such as supply chains and distribution remain obscured. Technology-based solutions form a popular narrative in existing and new policies targeting growth in the agroindustrial sector. They contribute to persisting narratives of 'digital India' as well as 'smart villages' and 'smart cities'. While these common technological framings of efficiency and transparency for development in app-provided services privilege the creation of digital ecosystems, they camouflage the people and messy practices that underlie them.

Based on interviews, participant observation and secondary data analysis, this paper explores the practices of $\mathrm{B} 2 \mathrm{~B}$ e-commerce firms in the food sector. It unpacks these networks of actors to understand the form and role of technology in maintaining, destabilising, disrupting or transforming food supply chains across scales, and the implications of these shifts for people and processes, paying special attention to issues of power and difference.

The easing of restrictions on foreign direct investment (FDI) in retail as well as increased access to venture capital funding has led to a flurry of small firms attempting to capture a share of a growing market by providing technological services that link farmers with small and large retailers such as small grocers/kirana shops. Much of their claimed success is attributed to the adoption of technology in terms of its ease of use, its elimination of middlemen, and consequently the benefits these innovations ostensibly provide to both farmers and retailers.

These technologies (usually web- or mobile-based applications) do not work in isolation, but are embedded in complex networks of producers, processors, logistics suppliers, wholesalers, distributors and retailers. All these relationships are mediated by applications whose functioning is punctuated by an overlapping network of personnel employed to link gaps in these infrastructures, and forming parts of the infrastructure themselves. The applications are themselves constructed to reflect the interests and predilections of their designers, leading to particular forms of engagement with different actors, and particular structures that shape these. Through its purported embedding of farmers into decision-making practices that feedback from data collected through machine learning algorithms that link producers with distributors and consumers, various actors interact with the app to curate a new form of market place. These marketplaces gain salience in circuits of capital and policy based on their ostensible contributions to different sets of interests, with farmer interests being privileged in public discourse. 
Scholars of science and technology such as Gabrys (2014) and Knorr-Cetina (2004) have long since questioned this unreflexive privileging of technology, and highlighted the need to consider its economic, material, social and political practices to make evaluative claims of what it actually does. Following this, the paper attempts to answer the following question: how do new e-commerce B2B firms reconfigure existing food supply chains in terms of actors, networks and regions?

Research indicates that a useful lens to adopt for the study of the interaction of technology with people and institutions is to think of technology as practice, paying attention to the networks and actors that make up the space that new market forms inhabit. Such networks are configured by both multiple and diverse rationalities and ideologies as well as disparate constituencies that take particular forms through situated practices. Here ideological agendas, networks of knowledge and manufacturing infrastructures function to acquire economic value that hinge on a particular characterisation of environmental processes, values and norms that cross-cut regional, national and global boundaries, as well as pivot off networks of actors across multiple zones, actions at multiple scales, and an amalgamation of 'things'. This technological economy may work to commodify ecological knowledge and affective relationships with nature to profitable ends.

Thus the different B2B firms we study exhibit a multiplicity of interests and forms of functioning, each intersecting with existing food chains at different points to reshape how different actors participate in it. Farmers, for example, benefit from the ability to supply produce to collection centres located close to their farms where prices are pre-determined, as opposed to travel to the Agricultural Produce Marketing Committee (APMC) markets where they must deal with commission agents and traders. The entry of B2Bs in this space is also shaping how the APMC itself functions, by their ability to procure produce right from the source, set quality and grading norms, mobilise large logistical operations, and over time, command greater influence over food-supply chains with increasing deregulation of agribusiness functioning. Many firms are now beginning to offer small loans and production inputs to farmers, further consolidating their reach. These changes are made possible through the strong weaving of technology into these chains that simultaneously brings large amounts of data and numbers of actors together, while at the same time by linking them largely through depersonalised algorithms that function through a mobile application, keeps them disconnected from each other. So while the idea of 'big food' in India does not correspond with scholarship in the global North of concentrated, large conglomerate-led supply chains, corporate-led 'small food' in India is changing the rules of the game.

\section{References}

Gabrys, J. (2014). Programming environments: Environmentality and citizen sensing in the smart city. Environment and Planning D: Society and Space, 32(1), 30-

48. https://doi.org/10.1068/d16812

Knorr-Cetina, K. (2004). From pipes to scopes: The flow architecture of financial markets. The Technological Economy, (7), 122-140. https://doi.org/10.4324/9780203022450 


\section{Millet Trails, from market-town to city-region: Exploring sustainable food narratives in Bangalore}

Salila Vanka; R V College of Architecture; Dwijendranath Guru; The Millet Foundation

With the backdrop of recent governmental and nongovernmental initiatives in Karnataka to promote production and consumption of local food in and outside the state, this research examines how millet-based food systems are shaping sustainable food narratives, urban-rural linkages and thereby the notion of 'region' in the Bengaluru foodshed. ${ }^{1}$

Technological advances, economic policies and global food systems have helped in mitigating food scarcity and hunger world over, but have also led to unsustainable food production and supply processes among several negative impacts. In a report on resilient food systems, the Food and Agriculture Organisation of the United Nations (2015) notes that 'The way today's population is fed is culpable for a catastrophic loss of biodiversity, habitat destruction, overabstraction of water for irrigation, freshwater pollution, extensive soil erosion, and widespread over-fishing.' In addition to harming nature and natural resources, modern food systems have also sharpened the divides between notions of urban and rural.

These divides_of social, economic, geographical, cultural and political characteristics (and administrative policies and governance) of urban and rural areas - are certainly prevalent in India. While acknowledging the benefits of cities as liberating, democratic and uplifting sites of human habitation, sociological readings of post-industrial societies also highlight the dehumanising effects of urban life as it weakens ties between communities, culture and land (Tonnies, 1887; Simmel, 1903). To date, there persist gaps in income, opportunities and standard of living between urban and rural areas in India. Spatially though, the gap between urban and rural areas continues to shrink, as rapidly growing Indian cities engulf and devour several villages that lay in their path to growth and development.

The social gaps and spatial takeovers have been disruptive to local food systems, agrarian livelihoods and urban-rural linkages (Cronon ,1991). It is imperative that we address and amend these disruptions since, 'food systems cannot be understood in isolation from the other systems and processes that they intersect with; and nor can the impacts of the food system on other socio-ecological systems be ignored.' (FAO, 2015)

In his book Nature's Metropolis: Chicago and the Great Midwest (1991), environmental historian William Cronon discusses the city's debt towards inseparability from its rural hinterland. Cronon (1991) writes,

"A city's history must also be the history of its human countryside, and of the natural world within which city and country are both located. We cannot understand the urban history of Chicago apart from the natural history of the vast North American region to which it became connected. Nature's Metropolis and the Great West are in fact different 
labels for a single region and the relationships that defined it. By erasing the false boundary between them, we can begin to recover their common past". (19)

Erasure of the 'false' urban-rural boundary, gives a suitable opening to the discussion on sustainable food systems 'that aim at achieving food and nutrition security and healthy diets while limiting negative environmental impacts and improving socio-economic welfare' (CIAT, 2018). The region, comprising the city and the village, is a suitable unit of analysis and discussion to understand how to build sustainable food systems and healthy communities that enjoy food security 'when all people, at all times, have physical and economic access to sufficient, safe and nutritious food to meet their dietary needs and food preferences for an active and healthy life' (FAO, 2015). ${ }^{2}$

The term 'region' has various definitions, but this research reflects Scottish biologist-planner Sir Patrick Geddes' illustration of the region in his Valley Section diagram. ${ }^{3}$ Geddes (1905) highlights the city-region interconnectedness thus:

"By descending from source to sea we follow the development of civilisation from its simple origins to its complex resultants; nor can any element of this be omitted. Were we to begin with the peasant hamlet as our initial unit, and forget the hinterlands of pasture, forest, and chase (an error to which the writer on cities is naturally prone), the anthropologist would soon remind us that in forgetting the hunter, we had omitted the essential germ of active militarism, and hence very largely of aristocratic rule. Similarly, in ignoring the pastoral life, we should be losing sight of a main fount of spiritual power, and this not only as regards the historic religions, but all later culture elements also, from the poetic to the educational. In short, then, it takes the whole region to make the city. As the river carries down contributions from its whole course, so each complex community, as we descend, is modified by its predecessors. The converse is no doubt true also, but commonly in less degree." (105-6)

Geddes's definition of the city-region from the early 20th century is reflected in FAO's 2013 definition of the city-region food system as 'the complex network of actors, processes and relationships to do with food production, processing, marketing, and consumption that exist in a given geographical region that includes a more or less concentrated urban centre and its surrounding peri-urban and rural hinterland; a regional landscape across which flows of people, goods and ecosystem services are managed ${ }^{\prime 3}$, (Dubbeling, 2017). This research is thus concerned in understanding the potential and possibilities of a millet-based food system (grow, buy, consume, recycle local) to reduce the urban-rural divide, strengthen urban-rural linkages and promote food security in the Bengaluru city-region.

Millets are hardy and nutritious cereal grasses with edible seeds that agriculturists have cultivated in Karnataka since pre-colonial times. ${ }^{4}$ Various natural and socioeconomic factors made millet grains such as ragi (finger millet) and jola (sorghum/jowar) a staple element in the 
local cuisine. In his three-volume book chronicling his survey of South India, A Journey from Madras through the countries of Mysore, Canara and Malabar (1807), Scottish biologist and physician Francis Buchanan makes detailed observations regarding the cultivation patterns of millet grains and their significance as daily sustenance of indigenous communities in and around Bengaluru. Buchanan (1807) writes,

"The grounds are of three kinds; wet land, or that watered artificially, and producing what were called wet crops, or grains; dry field, or that which receives no artificial supply of water, ad which produces dry crops or grains; and gardens or Bagait (83) ... The crop of Ragy is by far the most important of any raised on dry field, and supplies all the lower ranks of society with their common food. Among them, it is reckoned the most wholesome and invigorating food for labouring people; and in every country, most fortunately, a similar prejudice appears to prevail, the most common grain being always reckoned the nourishment most fit for the labourer (101-2) ... Jola is the next most considerable dry crop ... It is often sown for fodder; for when the crop is not uncommonly good, the grain is no object ... crops of Ragy and Jola were generally taken alternately, the crop of Ragy having an extraordinary allowance of dung ... The Jola requires less rain than the Ragy, and admits of a second crop of Huruli ${ }^{5}$ being taken after it; and thus, in the course of two years, there are on the same ground, three crops." (104)

Buchanan's account shows that ragi and jola were dominant crops in Karnataka, valued for their resilience, complementarity, low maintenance, multiple uses and nutritional content. It is noteworthy that millet grains were the staple food of economically weaker populations, a tag that the millet grain carries to this day. Bengaluru's streets are dotted with affordable food stalls and khanavalis (eateries) selling ragi mudde (ragi ball) and jolada rotti (jowar bread) and doing brisk business with mealtimes. At the same time, the humble millet grain (in unprocessed and processed form) also sells for high prices in urban artisanal bazaars and organic food places targeting affluent populations.

Millet grains still remain on the fringe of the food systems as gaps in pricing, cultural perceptions and palates challenge both government and grassroots initiatives to promote millet grains in Karnataka. A recent article on agricultural policy in India, suggests a 'conservation agriculture' approach because, 'globally, conservation agriculture has provided a common thread for the application of five sustainability principles-efficient use of water, reduced use of agrochemicals, improved soil health, adapt to climate change, and doubling farmer income-in order to tie the mix of interventions with local needs and priorities of the farmers' (84, Gupta et al, 2018).

To counter the dropping production of millet grains in the past decades, the Karnataka state government has been actively promoting millet-grain-based foods in urban areas, through the PDS, millet stores, promotional and educational fairs (Aji, 2017). The state government is also 
investing in research and development efforts and incentives to farmers to boost millet grain production. Grassroots efforts such as Ragi Kana ${ }^{6}$, Buffalo Back Collective ${ }^{7}$, Jivabhumi ${ }^{8}$ and others are working with rural communities around Bengaluru to build sustainable market systems, and rely on social media and word-of-mouth marketing. While these efforts are considerably new and may yield positive results in the long term, presently they appear fragmented, without a larger picture of a sustainable Bengaluru city-region.

This research proposes that in order to create markets for local foods and communities, governmental policies and programmes must first develop a sustainable city-region food system that manages flows of people, goods and ecosystem services equitably. In current regional planning processes in India, food is discussed only in the language of agricultural land and productivity. This research suggests that regional planning should engage directly with the idea of the region as a food system, where urban-rural linkages are strengthened by building resilient local food networks and communities.

Keywords: Millet Grain Economy, Sustainable Food Systems, Agrarian Livelihoods, Bangalore City-Region, Conservation Agriculture, Food Policies

\section{Endnotes}

1 'A foodshed is the geographical area between where food is produced and where that food is consumed. The foodshed concept is similar to a watershed-both encompass the flow of a substance from its origin to its ultimate destination.' (Hahn, 2013)

${ }^{2}$ A recent study on food security in India revealed that 'India is among 29 countries with the highest levels of hunger, stunted children and poorly fed women', according to the International Food Policy Research Institute (IFPRI)'s Global Hunger Index 2010. 'Despite a strong economy, India ranked 67th among 85 countries in terms of access to food.' (LEISA India, 2018)

${ }^{3}$ Geddes' illustration of the Valley Section (1909) can be viewed at https://commons.wikimedia.org/ wiki/File:Valley_Section,_1909.png (Retrieved on 28 October 2018)

4 'Millets: any of [the] several species of cereal grasses in the family Poaceae, [are] cultivated for their small edible seeds. Millets were probably first cultivated in Asia more than 4,000 years ago, and they were major grains in Europe during the Middle Ages. Today, though they are used chiefly for pasture or to produce hay in the United States and western Europe, they remain important food staples in less- developed countries worldwide. Millet grains are high in carbohydrates, with protein content varying from 6 to 11 percent and fat varying from 1.5 to 5 percent.' (Encyclopaedia Britannica 2016)

${ }^{5}$ Horsegram

${ }^{6}$ Ragi Kana - A Sunday Santhe. 2017. https://ragikana.wordpress.com/ (Accessed 28 / 10 /2018)

${ }^{7}$ Nirupama V. 2016. 'How Buffalo Back is delivering goods and a green message' in Economic Times, https://economictimes.indiatimes.com/news/politics-and-nation/how-buffalo-back-is- 
delivering-goods-and-a-green-message/articleshow/53593441.cms (Accessed $17 / 10$ / 2018)

8 Jivabhumi - A community supported agriculture initiative: Bringing you naturally grown food from your local farmer, http://jivabhumi.com/ (Accessed 17 /10 / 2018)

\section{References}

Aji, S. (2017, April 9). How Karnataka is transforming state's humble and traditional food into an urban delight. The Economic Times. Retrieved from

https://economictimes.indiatimes.com/news/economy/agriculture/how-karnataka-istransforming-states-humble-and-traditional-food-into-an-urbandelight/articleshow/58086974.cms

Buchanan, F. (1807). A journey from Madras through the countries of Mysore, Canara and Malabar. Londo: T. Cadell and W. Davies.

CIAT. (2018). Sustainable Food Systems [Blog post]. Retrieved from https://ciat.cgiar.org/about/strategy/sustainable- food-systems/

Cronon, W. (1991). Nature's metropolis: Chicago and the great west. New York: W. W. Norton \& Company.

Dubbeling, M., Santini, G., Renting, H., Taguchi, M., Lançon, L., Zuluaga, J., ... \& Andino, V. (2017). Assessing and planning sustainable city region food systems: Insights from two Latin American Cities. Sustainability, 9(8), 1455. https://doi.org/10.3390/su9081455 FAO. (2015). Food in an urbanized world: The role of city region food systems in resilience and sustainable development. Retreived from http://www.fao.org/fileadmin/templates/agphome/documents/horticulture/crfs/foodurb anized.pdf

Denis, E., Mukhopadhyay, P., \& Zérah, M.-H. (2012). Subaltern urbanisation in India. Economic and Political Weekly, 47(30), 52-62.

FAO. (2013). The State of Food and Agriculture. Rome.

Geddes, P. (1905). Civics: as applied sociology. London: Macmillan

Geddes, P. (1909). Valley Section. Wikimedia commons. Retrieved from https://commons.wikimedia.org/wiki/File:Valley_Section,_1909.png

Gupta, R., Mehra, M., Sahoo, R. N., \& Abrol, I. (2018). Indian agriculture redefining strategies and priorities. Economic \& Political Weekly, 53(41), 84-91.

Hahn, K. (2013). What is a foodshed?. Retrieved from http://www.canr.msu.edu/news/ what_is_a_food_shed (Accessed $27 / 10$ / 2018).

LEISA India. (2018). Editorial - regional food systems. Retrieved from https://leisaindia.org/editorial-regional- food-systems/

Simmel, G. (1903). The metropolis and mental Life. In G. Bridge \& S. Watson, (Eds.), The blackwell city reader (pp. 103-110). Malden, MA: Blackwell Publishing Ltd.

The Editors of Encyclopaedia Britannica. (2016). Millet. Encyclopedia Britannica. Retrieved from https://www.britannica.com/ plant/millet-plant

Tonnies, F. (1887). Community \& Society (Gemeinschaft Und Gesellschaft). East Lansing: Michigan State Univer. 


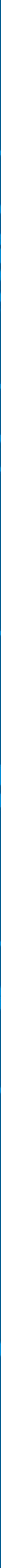


A Study of the Mhalunge-Maan town planning scheme: Juxtaposing the scope for public negotiation under land pooling with the use of eminent domain under land acquisition

Varun Panickar; Indian Institute for Human Settlements

\section{Problem Statement}

The proposed study seeks to understand the bargaining power of land owners in the Mhalunge-Maan land pooling scheme situated on the outskirts of Pune's urban district. There have been other studies examining the veracity of the land pooling method's ability to allow land owners to negotiate a 'fair' deal for their land with the state. This study seeks to distinguish itself by juxtaposing the scope for free and fair negotiations in the land pooling method with the use of eminent domain in the context of land acquisition. Land pooling is fast emerging as a 'win-win' alternative to the use of land acquisition in the state's bid to facilitate urbanisation.

\section{Context}

Land pooling, also known as land reconstitution and town planning schemes, have recently emerged as the preferred choice of planning and urban development authorities across the country are using this method to ensure planned growth and infrastructure provisioning in peri-urban areas. While the use of land pooling methods is not recent, its deployment was largely restricted to peri-urban development schemes in Gujarat. However, in the last few years the model has seen increasing usage across states like Andhra Pradesh, Delhi and Maharashtra.

Increased use of the land pooling method is especially noticeable since it is being used to substitute the land acquisition method, which has hitherto been the traditional means for the state to bring private land under its control for purposes of development. In fact, the statement of objects and reasons to the land acquisition legislation highlights the use of the method to facilitate urbanisation.

It is likely that the lure of avoiding a hold-out by private landowners makes the land pooling method a much more attractive proposition to the use of land acquisition. The land acquisition process is widely perceived as being a means for the state to exercise a very heavy-handed version of eminent domain. Naturally, land acquisition processes are usually mired in litigation, with inadequate compensation and inadequate rehabilitation measures being a chief concern of land owners. In contrast, land pooling claims to offer land owners a betterment of their land value without the need to evict land owners off their property. Since all this is done while receiving the consent of at least 70 percent of the land owners in a project and without the unilateral use of eminent domain, it is also seen as providing adequate scope for the land owners to negotiate the terms of the project. 
The Mhalunge-Maan town planning scheme led by the Pune Metropolitan Region Development Authority (PMRDA) is the first of at least 10 such town planning schemes located in villages along the soon-to-be-developed outer ring road to the city. The Mhalunge-Maan project is meant to act as a mentor to other town planning schemes which will follow. The initial public consultations for the project have been completed and the scheme is projected to be completed in the next two years.

It is in this context that this study seeks to examine the nature of public negotiations that take place between the land owners in Mhalunge-Maan and the planning authorities. This is especially relevant in the light of the land pooling method's claim to enabling free and fair negotiations between private land owners and the state. The scope for public negotiation is also relevant to understanding the relative advantage that this method enjoys over the use of eminent domain in land acquisition projects. A better understanding of these interactions between the private land owners and the state could even lead to recommendations of a customised, mixed-methods approach.

Key words: city-region; activity centres; street network; hierarchy; landform

\section{References}

Khairnar, A. (2018, March 22). Pune's Mhalhunge town planning scheme to play 'mentor' for 46 upcoming towns near ring road project, Hindustan Times. Retrieved from https://www.hindustantimes.com/pune-news/pune-s-mhalunge-town-planningscheme-to-play-mentor-for-46-upcoming-towns-near-ring-road-project/storyOyXNDdO16J2ICMyXybQnjN.html.

Mahadevia, D., Pai, M., \& Mahendra, A. Schemes for Equitable Development-Glass Half Full or Half Empty?.Ministry of Housing and Urban Affairs. (2018). Pilot on formation of Local Area Plan (LAP) and Town Planning Scheme (TPS) for selected cities.

Sampat, P., \& Sunny, S. (2016). Dholera and the myths of voluntary land pooling. Socio Leg Rev, 12(2), 1-17.

Sanyal, B., \& Deuskar, C. (2012). A better way to grow? Town planning schemes as a hybrid land readjustment process in Ahmedabad, India. Value Capture and Land Policies, Cambridge, MA: Lincoln Institute of Land Policy, 149-82.

Sarkar, S. (2011). The impossibility of just land acquisition. Economic and Political Weekly, 35-38. 


\section{Looking through the towns and cities of Calcutta in Kolkata}

Sarani Khatua; University of Calcutta

City region in India made its way in post independence as a functional region that would develop in and around the core city. The first prominent perspective plan for metropolitan region, Basic Development Plan ${ }^{1}$ delineated the boundaries of the metropolitan area around the core city of erstwhile Calcutta. The delineation of the region was based on the continuous spread of the industrial belt that had already developed on the west and east banks of Hooghly contiguous to the core city. Fifty years hence, when West Bengal has possibly experienced a high level of transformation from rural to urban in terms of formation of census towns, the Kolkata megacity has witnessed decreasing demographic rate over the last decades, possibly the only one among the other megacities of India and also in the global South that has undergone a fall in urban agglomeration ranking. A close look at the agglomeration would reflect that the city has traversed a path of urbanisation that has long ignored its suburban periphery that was included within the region initially in the 1960s. Rather the state has been more active in producing new space on its rural periphery. In cities like Kolkata, though the suburban formed in the colonial period and curated in the postcolonial, it is the suburban development at the contemporary rural-urban interface (Roy, 2011) that has emerged primarily. The suburban space on which the region was initially delineated has been out of focus for a long time.

Post 1990s, constitutional recognition to the local self-government provided a boost to the governance in all municipalities, old and new. Then again the state continues to be primarily focussed on the new municipalities freshly curved out from the rural areas and the peri-urban areas to fulfil its dream of attaining a global image. Striving to have a global image of the region co-exists with getting hold on the populace residing in the peri-urban rather than the suburban. The region remains the same, the linkages between the city and the region remains almost the same, but the governmental initiatives associated with managing the linkages have changed. The core is building on a new periphery; it is more dependent on the new periphery to render the metropolis a global outlook. The new periphery has not evolved in one day or without contestation and there has been research and documentation presented through various case studies on east Kolkata development, development of Newtown at Rajarhat or the increasing threat to the east Kolkata wetland and so on. Nevertheless, it is still the representative periphery of the contemporary metropolis. The adjoining rural, which has already transformed owing to reducing hectares put under the net sown area, has led to an increase in the number of census towns in the adjacent district, and has become the site of the new urban order.

The question is what happens to the older municipalities that are still part of the same region? This is not to say that these municipalities cease to exist or vanish from the urban space. Constitutional recognition provided to the local self-government revamped the governability 
of these older municipalities, not to mention many things worked in their advantage as they are part of the metropolitan area and constituent part of the regional governance.

The 74th Constitutional Amendment Act 1992 (74th CAA 1992) enabled the local selfgovernments to be instrumental in raising internal revenue through municipal tax or to get entitled to a number of central and state level projects, though they may not necessarily be part of the state's aspiration of a global city. The older colonial town function as part of the metropolitan region as well as on its own.

The Kolkata urban agglomeration was perhaps the only agglomeration in India that witnessed a decline in the last World Urbanization Prospects 2014 Revision (UN-DESA, 2014). The decreasing demographic is often attributed to the core city of the agglomeration, but a closer look would reveal that most of the older municipalities, particularly those formed before independence, have witnessed a decline in demographics over decades. Only post the 74th CAA 1992 and consequent enactment of the West Bengal Municipal Act 1993 there was a rise in population of these municipalities following their increase in area and consolidation of adjacent areas. Most of these municipal governments were in suspension till then. The consequent decade witnessed an increase in the importance of municipal governance. New municipalities were formed and non-municipal towns were upgraded to municipal. The part of the urban agglomeration that is constituted by census towns have exhibited higher demographic growth and increase in numbers not only within the agglomeration but within the total metropolitan area. The region went through some major transformation through the inclusion of the New Town Kolkata Development Area within the metropolitan region, recently bringing for the first time two planning authorities under the same region.

It is no coincidence that any expansion of the metropolitan region is done through the inclusion of the adjacent rural area within the urban rather than including any adjoining municipal units. The rural forms the hotspot for the neoliberal development and the representative of Bengal's Biswa Bangla (Global Bengal) image rather than the existing municipalities. In the last decade alone there was 45 per cent increase in the number of census towns within the agglomeration while as far as statutory towns are concerned there was one addition and two within the whole metropolitan area. But the context of this paper is not about the formation of census towns, which has huge literature in recent urban research. Instead, the older municipalities are looked into, which are contained within the region or the older periphery that supported the core town. They do not directly form a part of the global aspiration of the state, but there has been a distinct change in their governance since the initiation of 74th CAA 1992. Also, as part of the greater metropolitan region they have been part of regional governance especially with respect to development of transport and communication lines or issues regarding solid waste management. These towns still serve as the main source of services to the city core or the new emerging periphery. They hold onto major projects like Atal Mission for Rejuvenation and Urban Transformation (AMRUT), previously National Urban Renewal Mission (NURM), and grants from the state besides the municipal revenue. 
This is not to negate the fact that despite the formation of constitutionally recognised local self-government, these other cities and towns have been subject to state centralisation. They are similar to their newer counterparts and even to their urban and rural counterparts in this respect. The other towns may not be the face of the state's vision of a global city, but they are not outside the domain of neoliberal practices. This paper has reviewed thoroughly different sets of census data and municipal statistics of the entire Kolkata metropolitan area; the two agglomerations constituted within it; the census towns; and the rural that is constantly evolving and would posit the context of demographically contained urbanisation of a megacity in the global South in the context of towns that were formed pre and postindependence. The paper would also use relevant informant interviews of those who are governing and are being governed in the discussion. As Kanai et al. have suggested that for cities like Kolkata, which are at the periphery of global urban studies (2017), we need to understand that the metropolis is also a conglomeration of different spatio-temporal units. It is necessary to take into cognizance that reconfiguration of the metropolis has been as prominently internal, as it is towards outward expansion. On the one hand, it is part of the Golden Quadrilateral, part of the Eastern Dedicated Freight Corridor at Dankuni, and is a site of ecstatic, sophisticated luxurious real estate ventures on the eastern fringe of the core city, and is a space of the future smart and private city on the east; the core does have deep linkages with its declining periphery, which was delineated decades back. This periphery was never meant to grow as growth centres on its own; the periphery was neither part of the global city vision, but these growth centres did not remain completely un-influenced by structural change, despite having higher slum concentration, declining population or even declining working population. Linkages of these towns with the core remain invisible and are often against the backdrop of production of the new space at the core as well as the periphery. In the backdrop of a gradually urbanising world, and various contestations and debates around inclusive urban development, it becomes all the more important to look into these ordinary urban spaces that provide multiplicity to the metropolis.

\section{Endnote}

${ }^{1}$ Calcutta Metropolitan Planning Organisation (CMPO): Basic Development Plan for Calcutta Metropolitan District. 1966-1986

\section{References}

Kanai, J. M., Grant, R. \& Jianu, R. (2017) Cities on and off the map: A bibliometric assessment of urban globalisation research. Urban Studies, 55(12), 2569-2585. https://doi.org/10.1177/0042098017720385

Roy, A. (2011). Re-forming the megacity: Calcutta and the rural-urban interface. In A. Sorensen \& J. Okata (Eds.), Megacities: Urban forms, governance and sustainability (93109). Tokyo: Springer.

UN-DESA. (2014) World urbanization prospects: The 2014 revision. http://www.indiaenvironmentportal.org.in/files/file/urbanization\%202014.pdf 


\section{Speculating on Bangalore's urbanism: Land transitions at the city's}

edge

\section{Carol Upadhya (corresponding author) Hemangini Gupta, Sachinkumar Rathod,}

Priyanka Krishna; National Institute for Advanced Studies

Urban scholars have been critiquing and rethinking received categories of analysis that frame much of urban research as well as policymaking. In this context, there is a growing consensus that binaries such as rural/urban, formal/informal, and state/market can no longer capture or explain the complexities of urban forms and processes, particularly in the global South. Calls for a postcolonial critique of urban studies (Robinson 2006), for 'new geographies of theory' (Robinson, 2016; Roy, 2009), and for a new 'epistemology of the urban' (Brenner 2013), reflect this unease with the conventional view of urbanisation (developed in the context of the European experience) as a linear progression from rural to urban, impelled by industrialisation and economic development (Nair 2013). To overcome this conceptual bind, Brenner (drawing on Lefebvre) advocates a shift of attention away from the 'city' or the 'urban' (and, by extension, the 'region') to urbanisation as a world-wide set of 'socio-spatial processes' driven primarily by capitalist accumulation. This perspective views urbanisation as a continual process of spatial restructuring that produces variegated landscapes (Brenner, 2014; Brenner \& Schmid, 2011). A central problem in forging a new theoretical framework to capture the complexities of the postcolonial urban experience is the relation between the 'rural' and the 'urban' (Roy 2016). In India, the dynamics of agrarian regions are thoroughly entangled with, and constitutive of, the urban, hence the logics of agrarian economies and social relations are also processes of urbanisation (Gururani and Dasgupta 2018: 42). Indeed, in most of the world 'the urban question is the agrarian question...' (2018: 43).

Urban scholars have documented the transformation of India's cities since the 1990s by processes of 'neoliberal urbanisation', reflected in the mushrooming of gated communities and luxury apartment complexes, glitzy shopping malls and manicured office parks: developments that have been attributed to economic reforms, the expansion of the service economy, and the rise of a consumption-oriented 'new middle class' (Brosius, 2010; Searle, 2016). The literature has also focussed on the urban reform policies of the 1990s that sharpened the demand for land for real estate and infrastructure development, often leading to violent slum evictions (Doshi, 2013; Ghertner, 2014, 2015; Weinstein, 2013). This body of work has largely overlooked the more quotidian and socially embedded processes through which cities such as Bengaluru have been (and are being) produced-in particular, the incremental conversion of agricultural land into real estate on the urban periphery.

However, researchers are increasingly paying attention to peri-urban spaces in South Asia: from Gurgaon and NOIDA in the National Capital Region (Cowan, 2018; Dubey, 2018; Sarkar 2015) to the hinterlands of Mumbai (Balakrishnan, 2018), Chennai (Raman, 2016), Kolkata 
(Kundu, 2016), and Karachi (Anwar, 2018). These studies have enriched our understanding of the complex entanglements of 'rural' and 'urban' which create the 'fractal' urban spaces (Dubey, 2018, citing Roy, 2011) that are so typical of urban peripheries. Gururani and Dasgupta (2018) employ the idea of 'frontier urbanism' to capture the 'heterogeneous politics of land. . .the feverish non-metrocentric remapping of the urban-agrarian hinterland that is taking place in South Asia' (2018: 41). It is in these 'agrarian-urban edges', they suggest, that we can track how 'new geographies of capitalist accumulation are spatially fixed and how the relentless negotiations, speculations, contestations, displacements, and dispossessions produce new urban subjects and social formations' (2018: 42). In Gurgaon for example, informal settlements and 'urban villages' nestle against high-end real estate projects and shopping malls, giving rise to the complex social fabric that Srivastava (2015) terms 'entangled urbanism'.

Bengaluru's spectacular urban growth, largely driven by the IT boom which created a huge demand for high-end residential and commercial space, has pushed the boundaries of the city ever outwards: an expansion that is supposedly regulated by, but often retroactively accommodated by, the periodic (and highly contested) revision of the Comprehensive Development Plan. On the south-eastern edge of the city where the fieldwork for this research was conducted, is the construction of one of the largest apartment complexes in Bengaluru, occupying over 100 acres of land, providing housing to software engineers and other professionals who work in nearby office parks. But just down the road one finds coconut groves and agricultural land still under cultivation, and between these 'urban' and 'rural' images are interspersed diverse signs of transition-open plots of barren land, ready for 'development'; half-built small apartment buildings lining traffic-choked rural roads; gated communities offering luxury 'villas' for sale; migrant labour camps fashioned out of blue plastic sheets; 'illegal' housing layouts carved out of agricultural land; and old agrarian villages still intact but undergoing rapid change as farmers rebuild their homes using money gained from the sale of land.

Such a landscape often feels illegible, as the histories of emptied land, under-construction real estate projects, and new buildings of varying sizes and aesthetic qualities seem to tell only the standard story of 'unplanned' urbanisation that is much lamented by the 'educated' middle classes and planners. Yet, digging beneath the surface of this apparently chaotic 'development' one can discern the socio-spatial maps and 'power geographies' (Herrod \& Wright, 2002) that create this fractured landscape: the opaque yet vibrant land markets that function through loose networks of brokers and local elites tied to shadowy but powerful politicians, who in turn are linked to at least one of the large professional land aggregators and real estate companies that control much of the city's land; the connections of caste and class that structure the agrarian economy and landholding system, now redeployed in the new urban context of lucrative land deals and city politics; and the regime of 'flexible planning' (Gururani, 2013) in which informal and formal mechanisms and institutions are deeply interdigitated within the micro-politics of urbanisation (Chatterji, 2013). In this frontier, new 
modes of accumulation and livelihoods are pursued by those who have been dislodged from the agrarian economy and are seeking a foothold in the urban: from small-scale land brokering and moneylending to tending the manicured gardens or cleaning the corridors of the new gated apartment complex (especially women) as contract workers. Enterprising farmers may become experts in cobbling together parcels of land for higher-level brokers, while other local actors may forge connections with land aggregators by persuading farmers to sell out. Narratives about the new wealth generated from brokering a single land deal abound in these peri-urban villages: people are eager to tell stories about a local man made good as a land broker or creator of 'layouts', who then leveraged his new money into a successful political career. Equally, stories of dislocation and precarity linked to the declining agrarian economy can be elicited from displaced agricultural labourers and marginal farmers who sold their land too early and find themselves deeper in debt. These divergent experiences are ultimately linked to the financialisation of land, as finance capital circulates through urban real estate and agrarian land markets, driving up prices and drastically altering the values of land and rural landscapes that surround the city.

In Bengaluru, land transition has been propelled by four or five major real estate companies, who have created sprawling IT campuses and apartment complexes with multiple tower blocks that dominate newly developed areas of the city. While large real estate projects often have infusions of capital from foreign equity partners (illustrating the role of global finance capital in disrupting agrarian economies), the urbanisation process has been pushed forward mainly by local and regional business interests. Agricultural land is purchased and assembled into parcels of 25 to 100 acres by professional land aggregators, who then sell these blocks to developers at great profit. Even in more distant villages, aggregators have created 'land banks' in anticipation of future demand; but the location and ownership of these parcels of appropriated land are difficult to determine, for this is valuable proprietary information that is not readily shared.

Beyond the mega-projects that gobble up large amounts of land, the agrarian land transition is occurring in more incremental ways as well, as real estate entrepreneurship works at multiple scales on the fringes of the city. In addition to the many modest apartment buildings that have sprouted up along rural roads, Reddy landlords have acquired more land (in some cases by encroaching illegally on village commons or by 'grabbing' assigned lands) on which they have created the 'layouts' that offer affordable properties to middle-class investors. While agrarian land gets converted into urban real estate through various pathways, all depend on 'informal' processes and networks to consolidate plots and navigate the maze of legal paperwork and official clearances required to complete the transactions: networks in which local intermediaries are key actors.

Drawing from on-going research on changes in land use and property relations, livelihoods and peri-urban ecologies in villages on the south-eastern edge of Bengaluru, ${ }^{1}$ this paper argues that India's 'neoliberal' urban transformation cannot be understood only in terms of 
the circulation of global capital or hegemonic policy prescriptions, but is deeply shaped by regionally specific social configurations and capital flows that structure the land and real estate markets. The paper explores the complex intersections of 'rural' and 'urban' on the peripheries of the expanding city through a focus on the transformation of rural land into urban real estate and the multiple reverberations of this transition, illustrated through the stories of a few key 'characters' from our field sites.

First, a preliminary map of the networks and modalities, are provided, through which agricultural land is turned into urban real estate, and the implications of this shift for processes of displacement and accumulation are discussed. To illustrate how these networks are structured by caste relations rooted in the agrarian economy, we present the stories of two local intermediaries-one Reddy and one Dalit—who provide links between local landowners and the urban actors that are hungry for land. These examples highlight the deep dependence of large urban land aggregators and real estate companies, in their quest to assemble large parcels of land, on local political and social networks.

Second, the multi-scalar value chains that facilitate the conversion of agrarian land into urban real estate, are traced, starting from the micro-level of the village, connecting through Bengaluru-based real estate and land aggregation companies and up to Wall Street private equity firms, illustrating the gradual interlocking of a rural economy with national and transnational financial networks (Goldman, 2011; Halbert \& Rouanet, 2014; Sud, 2017).

Third, recent debates on the land question in India and 'accumulation by dispossession' are addressed (Harvey, 2003; Levien, 2012). When farmers are persuaded to sell out to a developer or aggregator, they are distanced or alienated from land as a direct source of its use value, yet they are not necessarily dispossessed of all livelihood or income opportunities. Instead, as land becomes a speculative commodity, farmers often become key actors in creating and shaping regional land markets serving as brokers and middlemen, or by becoming rentier landlords or investing in agricultural land farther away from the city creating ripple effects far beyond the immediate peri-urban border of the city.

Finally, blurring of boundaries between human and non-human actors, rural and urban are explored, as transforming matter, divine beings, and flows of air, water and waste reshape the environment of this urbanising space. While documenting the persistent chasm between rural and urban forms of sociality and cultural capital, we also attend to their growing entanglements, as the expanding city engulfs agrarian communities, land and ecological landscapes. The paper offers some initial insights and reflections on the relation between the city and the agrarian region from which it draws its land, and on how rural economies and modes of life are altered by the multiple incursions of the 'urban'. 


\section{Endnote}

${ }^{1}$ This research project, entitled 'Speculative Urbanism: Land, Livelihoods, and Finance Capital', is being carried out in collaboration with colleagues at the Departments of Geography and Sociology, University of Minnesota, and is funded by the National Science Foundation, grant number BCS-1636437.

\section{References}

Anwar, N. (2018). Receding rurality, booming periphery: Value struggles in Karachi's agrarianurban frontier. Economic \& Political Weekly, 53(12), 46-54.

Balakrishnan, S. (2018). Seeing Mumbai through its hinterland: Entangled agrarian-urban land markets in regional Mumbai. Economic \& Political Weekly 53(12), 55-60.

Brenner, N. (2013). Theses on urbanization. Public Culture, 25(1), 85-114. https://doi.org/10.1215/08992363-1890477

Brenner, N. (2014). Introduction: Urban theory without an outside. In N. Brenner (Ed.), Implosions/Explosions: Towards a study of planetary urbanization (pp. 14-35). Berlin: Jovis.

Brenner, N. \& C. Schmid. (2011). Planetary urbanization. In M. Gandy (Ed.), Urban Constellations (pp. 10-13). Berlin: Jovis.

Brosius, C. (2010). India's middle class: New forms of urban leisure, consumption and prosperity. Routledge India.

Chatterji, T. (2013). The micro-politics of urban transformation in the context of globalisation: A case study of Gurgaon, India. South Asia: Journal of South Asian Studies, 36(2), 273-287. https://doi.org/10.1080/00856401.2012.739272

Cowan, T. (2018). The urban village, agrarian transformation, and rentier capitalism in Gurgaon, India. Antipode, 50(5), 1244-1266. https://doi.org/10.1111/anti.12404

Doshi, S. (2013). The politics of the evicted: redevelopment, subjectivity, and difference in Mumbai's slum frontier. Antipode, 45(4), 844-865.

Dubey, S. (2018). Urban transformations in Khora village, NCR: A view from the 'periphery'. Economic \& Political Weekly, 53(12), 76-84.

Goldman, M. (2011). Speculative urbanism and the making of the next world city. International Journal of Urban and Regional Research, 35(3), 555-581. https://doi.org/10.1111/j.14682427.2010.01001.x

Gururani, S. (2013). Flexible planning: The making of India's 'Millennium City,' Gurgaon. In A. M. Rademacher \& K. Sivaramakrishnan (Eds.), Ecologies of urbanism in India: Metropolitan civility and sustainability (pp. 119-143). Hong Kong: Hong Kong University Press.

Gururani, S., \& Dasgupta, R. (2018). Frontier urbanism urbanisation beyond Cities in South Asia. Economic and Political Weekly, 53(12), 41-45.

Ghertner, D. A. (2014). India's urban revolution: geographies of displacement beyond gentrification. Environment and Planning A, 46(7), 1554-1571.

Ghertner, D. A. (2015). Why gentrification theory fails in 'much of the world'. City, 19(4), 552563

Halbert, L., \& Rouanet, H. (2014). Filtering risk away: Global finance capital, transcalar territorial networks and the (un) making of city-regions: an analysis of business property 
development in Bangalore, India. Regional Studies, 48(3), 471-484.

https://doi.org/10.1080/00343404.2013.779658

Harvey, D. (2003). The New Imperialism. Oxford: Oxford University Press.

Herrod, A., \& Wright, M. W (Eds.). (2002). Geographies of power: Placing scale. Malden, MA: Blackwell.

Kundu, R. (2016). Making sense of place in Rajarhat new town: The village in the urban and the urban in the village. Economic \& Political Weekly, 51(17), 93-101.

Levien, M. (2012). The land question: Special economic zones and the political economy of dispossession in India. The Journal of Peasant Studies, 39(3-4), 933-969. https://doi.org/10.1080/03066150.2012.656268

Nair, J. (2013). Is there an Indian urbanism? In A. Rademacher \& K. Sivaramakrishnan (Eds.), Ecologies of urbanism in India: Metropolitan civility and sustainability (pp. 43-70). Hong Kong: Hong Kong University Press.

Raman, B. (2016). Reading into the politics of land: Real estate markets in the south-west periurban area of Chennai. Economic \& Political Weekly, 51(17), 76-84.

Robinson, J. (2006). Ordinary cities: Between modernity and development. London: Routledge. Robinson, J. (2016). Comparative urbanism: New geographies and cultures of theorizing the urban. International Journal of Urban and Regional Research, 40(1), 187-199. https://doi.org/10.1111/1468-2427.12273

Roy, A. (2009). The 21st century metropolis: New geographies of theory. Regional Studies, 43 (6), 819- 830. https://doi.org/10.1080/00343400701809665

Roy, A. (2011). Slumdog cities: Rethinking subaltern urbanism. International Journal of Urban and Regional Research, 35(2), 223-238. https://doi.org/10.1111/j.1468-2427.2011.01051.x

Roy, A. (2016). What is urban about critical urban theory?. Urban Geography, 37(6), 810-823. https://doi.org/10.1080/02723638.2015.1105485

Sarkar, S. (2015). Beyond dispossession: The politics of commodification of land under speculative conditions. Comparative Studies of South Asia, Africa and the Middle East, 35(3), 438-50. https://doi.org/10.1215/1089201X-3426289

Searle, L. G. (2016). Landscapes of accumulation: Real estate and the neoliberal imagination in contemporary India. Chicago: University of Chicago Press.

Srivastava, S. (2015). Entangled urbanism: Slum, gated community and shopping mall in Delhi and Gurgaon. New Delhi: Oxford University Press.

Sud, N. (2017). State, scale and networks in the liberalisation of India's land. Environment and Planning C: Politics and Space, 35(1), 76-93. https://doi.org/10.1177/0263774X16655801 Weinstein, L. (2013). Demolition and dispossession: toward an understanding of state violence in millennial Mumbai. Studies in Comparative International Development, 48(3), 285-307. 
Inter-relation between landform characteristics and hierarchy of street network: Taking the case of Greater Bengaluru metropolitan region

Jeeno George; BMS College of Architecture

\section{Introduction}

Geometries found in the nature and in cities are similar as it is the laws of nature which govern the constraints of physical space within which these geometries emerge (Alexander, 2002; Bejan \& Zane, 2012). Bejan \& Zane (2012) use 'constructal law' to describe the emergence and evolution of these tree-like structures commonly found in nature. For any city, the streets are the movement channels that facilitate flow access to humans and at the same time contribute to the wider urban structure (Marshall, 2005).

The similarities between geometries found in nature, such as a tree, and geometries found in cities, in particular, the organic ones, are striking. In the formation and transformation of human settlements, the configuration and geometry of land relief influence the location and future form of the settlements (Urban morphology, 2016). However, due to the complex interrelations between landforms and urbanisation, the correlated urban infrastructure has highly impacted, and in many times destroyed landforms (Reynard, Pica, \& Coratza, 2017) which often results in the partial or total invisibility of landforms whose protection from such encroachments are weak.

In the master's and doctoral thesis of Guerreiro (2001, 2011), she synthesises key elements of structural relief that influences the urban form as ridge lines, drainage lines and contour lines (Oliveira, 2016). According to her, these three elements of macro-relief influence the lines of movement and development-of-activity nodes of the settlement. The lines of movement or the transportation network is expected to follow this natural structure of territory as they represent the direction of least resistance. The points where these lines of movement branch out naturally usually become the activity centers.

As cities grow and communication systems develop, due to agglomeration diseconomies the polycentric form becomes inevitable, thereby extending beyond the city boundary into the surrounding regions. The most general principle governing the formation of polycentric cities are the sub-centres. The sub-centres are the outcome of two opposing set of forces: those favoring concentration due to agglomeration and those favouring dispersion due to congestion cost (Dowall \& Alan Treffeisen, 1991; Gordon, Kumar, \& Richardson, 1989). A subcentre is a zone that is characterised by greater population densities, employment levels or commercial activity than the surrounding areas (Dökmeci \& Berköz, 1994, p. 3; McMillen, 2001, n.d.). 
Out of the different communication networks, the street network is the most important and articulated infrastructure network. The street network is considered to be close to mathematical objects since the 18th century (Murcio et al., 2015). The characteristics of the street network are that it preserves its historical and geometrical properties as the city evolves. Street networks evolve through planning decisions and self-organisation; and in turn shape human connections and interactions within the city (Boeing, 2017c). It is resilient to change and hence it is possible to study their long-term evolution (Boeing, 2017a). The surface transport network forms the internal structure of the city, and it can indicate the performance of the city (Levinson, 2012).

The hierarchical arrangement of activity centres and communication systems is an observed common property in urban systems established in the twentieth century with Christallers and Losch's theory (Christaller \& Baskin, 1966; Losch, 1938). Hierarchy is the order of importance. The geometric properties of streets such as the street lengths and street angles along with the topological properties such as the centrality measures can be used to understand the hierarchical structure of the street network (Jiang, 2009). The nodes and links will have different levels of importance due to various reasons. This attribute can be used to arrange them hierarchically. The degree of spatial correspondence of the topographic lines with roads can be analysed to check whether it coincides with the natural lines of movement. According to Oliveira (Oliveira, 2016), referring to the master's and doctoral thesis of Rosália Guerreiro, the ridge lines, as well as the thalweg lines, are associated in branched hierarchical systems forming orographic and hydrographic systems. The points where ridge lines and thalweg lines are ramified are the notable points of the territory, usually referred to as distribution centres and encounter centres.

To analyse the hierarchical structure, one must determine the order of the links. Hack's order, Horton's order, Strahler order, and Shreve order are methods to determine the order of streams (Haggett \& Chorley, 1969). The order of the links can be used to find the bifurcation ratio, which is the ratio of the number of links in one order to the number of links in the next higher order (Kimerling, 2009). The bifurcation ratio of different networks can be compared, and the difference can be explained due to landform constraints, climate, cultural changes, etc. These can then be used to explain the spatial patterns.

The objective of the paper is to analyse the spatial correspondence between landform constraints and hierarchy of street networks taking the case of Greater Bengaluru Metropolitan region. Bengaluru, a city in South of India, is undergoing unprecedented urbanisation. The spatial extent of the city has increased from 69 sq. km. in 1949 to 745 sq. km. in 2011. 


\section{Method}

The analysis uses urban street network of the region. The work uses the primal, planar form of the street network. The primal and the dual form of the street network can be used to analyse streets as graphs. However, for the study, the primal form is considered. The primal representation focusses on metric measures which refer to geometric areas and length such as average street segment length, node density, edge density, street density, and so on. Therefore, the primal representation of street networks is found to provide a better picture of the centrality measures in an urban area concerning structural properties.

While the geometric properties exhibit 'universal behaviour,' centrality indices can be used to cluster the cities (Strano et al., 2013). Centrality measures are suitable for spatial studies as they can be mapped and visualised. The centrality indices differ between cities mainly due to the influence of landform constraints on the network. A multi-faceted centrality index (MCA) is required to capture different ways for a place to be central and for a deeper understanding of how cities work (Porta et al., 2006b). Porta et al. (Porta et al., 2006b) comprehend that using the primal network for measures of centrality when compared to dual representation, contributes to the extended comprehension of 'hidden order.'

The brief description of various centrality measures is as follows. Degree centralities find the important nodes which have the largest number of ties to other nodes in the graph. Betweenness centralities or 'choice' refers to the node which is more central. The between-ness centrality of a node is more when it is traversed by a large number of the shortest paths connecting all couples of nodes in the network. Closeness centralities or 'integration' measures how close each node is to all others under each definition of distance. It is the classical centrality index. In space syntax, 'integration' is the index for accessibility. Straightness centrality is the efficiency in communication between two nodes and is equal to the inverse of the shortest path length. Information centrality is the relative drop in the efficiency of the network caused by the removal of edges incident in the node. It captures the criticality of edges that play a 'bridging' role in keeping the network connected, at the same time partially retaining the behaviour of centrality between-ness (Porta et al., 2006b).

The properties of the street network are measured using network analysis plug-in in qGIS. In a Geographic Information System (GIS) platform, the street networks are overlaid on the Digital Elevation Model (DEM) of the terrain to extract spatial association rules by (i) relating the influence of the 'structuring line of the territory (Oliveira, 2016)' with the evolution of the street network, and (ii) relating the hierarchy of nodes determined by centrality measures of the street network with the notable points of territory formed at the ramification points of the ridge lines and drainage lines.

The summary of the workflow is as follows:

a) Identifying ridge lines and drainage lines using DEM

b) Quantifying the hierarchical order of 'distribution centres and encounter centres' using the order of the links 
c) Analysing the degree of spatial correspondence of the topographic lines with roads and 'distribution centres and encounter centres' with activity centres

d) Result

The ridges and drainage lines are found to have a significant influence on the emergence and stability of the street network system and activity, especially for the roads with higher centrality measures. We show how the ridge lines, drainage lines, and contour lines: the three elements of micro-relief, influence the lines of movement and the development of activity nodes of the settlement. All major roads and urban sub-centres found using the method correspond positively to the existing ones.

Even though several socio-political and economic factors influenced the formation of the urban centres and sub-centres, the locational attributes seem to be governed by the natural laws of the territory.

\section{Conclusion}

This research adds to the knowledge of the 'science of cities'. The study is useful to explain the urban process of formation and transformation. The methodology can be used to compare cities. Moreover, it can help to predict urban change and make informed decisions to steer the trajectory of growth of cities to desired directions. This research elucidates another general principle which governs the formation of cities. Like living organisms, settlements originate and grow following certain underlying structural principles.

Key words: city-region; activity centres; street network; hierarchy; landform

\section{References}

Alexander, C. (2002). The nature of order: An essay on the art of building and the nature of the universe. Berkeley, California: Center for Environmental Structure.

Bejan, A., \& Zane, J. P. (2012). Design in nature: how the constructal law governs evolution in biology, physics, technology, and social organization. New York: Doubleday Publishing Group.

Boeing, G. (2018a). Measuring the complexity of urban form and design. Urban Design International, 23(4), 281-292.

Boeing, G. (2017b). Methods and measures for analyzing complex street networks and urban form (Doctoral dissertation). City and Regional Planning, University of California, Berkeley. Retrieved from https://arxiv.org/ftp/arxiv/papers/1708/1708.00845.pdf

Christaller, W., \& Baskin, C. W. (1966). Central places in southern Germany. Englewood Cliffs, N.J. : Prentic-Hall.

Dökmeci, V., \& Berköz, L. (1994). Transformation of Istanbul from a monocentric to a polycentric city. European Planning Studies, 2(2), 193-205.

https://doi.org/10.1080/09654319408720259

Dowall, D. E., \& Treffeisen, P. A. (1991). Spatial transformation in cities of the developing world. Regional Science and Urban Economics, 21(2), 201-224. 
https://doi.org/10.1016/0166- 0462(91)90034-K

Gordon, P., Kumar, A., \& Richardson, H. W. (1989). The influence of metropolitan spatial

structure on commuting time. Journal of Urban Economics, 26(2), 138-151.

https://doi.org/10.1016/0094-1190(89)90013-2

Guerreiro, M. R. da P. (2010). Organic urbanism and the implicit order: a reading through the

geometries of nature. Retrieved from http://hdl.handle.net/10071/2911

Haggett, P., \& Chorley, R. J. (1969). Network Analysis in Geography. London: Edward Arnold.

Jiang, B. (2009). Street hierarchies: A minority of streets account for a majority of traffic flow.

International Journal of Geographical Information Science, 23(8), 1033-1048.

https://doi.org/10.1080/13658810802004648

Kimerling, A. J., Buckley, A. R., \& Muehrcke, P. C. (2009). Map use: Reading and analysis. New York: ESRI Press Academic.

Levinson, D. (2012). Network structure and city size. PLoS ONE, 7(1), e29721.

https://doi.org/10.1371/journal.pone.0029721

Losch, A. (1938). The nature of economic regions. Southern Economic Journal, 5(1), 71-78. https://doi.org/10.2307/3693804

Marshall, S. (2005). Streets \& patterns. London; New York: Spon Press.

McMillen, D. P. (2001). Nonparametric employment subcenter identification. Journal of Urban Economics, 50(3), 448-473. https://doi.org/10.1006/juec.2001.2228

McMillen, D. P. (2003). Employment subcenters in Chicago: Past, present, and future. Economic Perspectives, 27(2), 2-13.

Murcio, R., Masucci, A. P., Arcaute, E., \& Batty, M. (2015). Multifractal to monofractal evolution of the London's street network. Physical Review E, 92(6).

https://doi.org/10.1103/PhysRevE.92.062130

Oliveira, V. (2016). Urban morphology: An introduction to the study of the physical form of cities. Switzerland: Springer International Publishing.

Porta, S., Crucitti, P., \& Latora, V. (2006). The network analysis of urban streets: A primal approach. Environment and Planning B: Planning and Design, 33(5), 705-725.

https://doi.org/10.1068/b32045

Reynard, E., Pica, A., \& Coratza, P. (2017). Urban Geomorphological Heritage. An Overview. Quaestiones Geographicae, 36(3). https://doi.org/10.1515/quageo-2017-0022

Strano, E., Viana, M., da Fontoura Costa, L., Cardillo, A., Porta, S., \& Latora, V. (2013). Urban street networks, a comparative analysis of ten European cities. Environment and Planning B: Urban analytics and city science, 40(6), 1071-1086. https://doi.org/10.1068/b38216 



\section{A cross-sectional and spatial analysis of the prevalence of multimorbidity and its association with socioeconomic}

disadvantage in South Africa: A comparison between 2008 and 2012

\section{Amy Weimann¹, Dajun Dai' ${ }^{2}$ Tolu Oni ${ }^{3}$}

${ }^{1}$ School of Public Health and Family Medicine, University of Cape Town, South Africa

${ }^{2}$ Department of Geosciences, Georgia State University, USA

${ }^{3}$ MRC Epidemiology Unit, University of Cambridge School of Clinical Medicine, Cambridge, United Kingdom

\section{Background and Theoretical Focus}

South Africa provides a remarkable context for urban health research, as the country's notorious apartheid history created great socioeconomic inequality by segregating and depriving the majority of the population (Adato, Carter, \& May, 2006). In addition, South Africa is believed to be undergoing an epidemiological transition where infectious diseases such as HIV and tuberculosis (TB), and non-communicable diseases (NCD) such as hypertension and diabetes, exist together in the population alongside perinatal and maternal, and injury-related disorders (Bradshaw et al., 2003). Moreover, an increasingly ageing population and a rise in the number of people taking anti-retroviral medication are contributing towards an ageing population of HIV-infected persons and an accompanying rise in coexisting health conditions, also known as multimorbidity (Tseng, Seet, \& Phillips, 2014). Multimorbidity not only affects the quality of life of individuals, but also results in complications in treatment plans and increased medical expenses. In South Africa, the prevalence of multimorbidity is largely unknown and there is a paucity of research on the social determinants of multimorbidity (Alaba \& Chola, 2013). In addition, there is limited research investigating the coexistence of many diseases, such as HIV, TB, hypertension and diabetes, as well as the association between multimorbidity and socioeconomic disadvantage (Ataguba, 2013). A possible association between multimorbidity and socioeconomic disadvantage may have unique implications for cities of the global South, particularly those with high levels of inequity as represented through a growth in slum conditions, as this is likely to suggest deep and complex interconnections between multimorbidity risk factors and systemic urban factors relating to poverty.

Drawing on Omran's (1971) theory of epidemiological transition, a country's state of health is expected to change and gradually respond to urban development, as well as be determined by and have consequences for the social, economic and demographic systems of society. In addition, Eyles (1985) draws attention to the interaction between the spatial concept of 'place' and one's position in society, and suggests that people's socioeconomic position in society will contribute to and influence the way they experience 'place'. In turn, an individual's location or 
'place', for example within a city, will produce different socioeconomic opportunities or hardships that may possibly shape their well-being and ultimately impact their health (Eyles, 1985).

\section{Data and Research Methods}

Due to the way in which health is likely to vary across key demographic, socioeconomic and spatial characteristics, this study aims to contribute to efforts in addressing the paucity of information on multimorbidity in South Africa by studying the epidemiology of selected chronic infectious and NCDs and multimorbidity, and their association with socioeconomic disadvantage in South Africa. This study utilised 2008 and 2012 data from the National Income Dynamics Study (NIDS), a panel study with a sample of just over 28,000 individuals that provides nationally representative socioeconomic, behavioural and anthropometric data for South Africa. Using an adult sample of 18,526 respondents and applying design and poststratification weights to the data, the age-adjusted prevalence of HIV, TB, hypertension, diabetes as well as multimorbidity were estimated for each spatial scale. Hypertension was identified as the most prevalent of the selected chronic diseases and most likely to contribute to multimorbidity. Therefore, it was included as an additional primary outcome variable in the multivariable analysis alongside multimorbidity.

Multivariable analysis was performed using two logistic regression models which included all significantly associated risk factors, descriptive variables (age, gender, racial groups, urban and rural geographies, and socioeconomic disadvantage), and the dichotomous outcome variable of either hypertension or multimorbidity. This analysis was limited to the national level as the models showed signs of instability at sub-national levels due to the high levels of non-response across variables and respondents. Possible confounding variables were identified using Directed Acyclic Graphs, while collinearity was tested for but none was found between any variables. Interactions were also tested for between obesity and age; however, their interaction terms did not contribute significantly to the final model and were not included.

Spatial analysis was performed using Geographic Information Systems (ESRI ArcGIS 10.3 desktop). The nine national provinces and the 52 South Africa Census districts, which exist as the second administrative level of South Africa below the provinces, were used as the spatial units of analysis. The Global Moran's I statistic was used to assess if there was clustering of multimorbidity across the South African districts, or if districts with similar multimorbidity prevalence were spatially situated near each other. Hot Spot analysis by means of the GetisOrd Gi* statistic was used to identify statistically significant hot and cold spots of multimorbidity across South African districts. In this study, a hot spot was defined as a clustering of high prevalence rates while a cold spot represented the clustering of low prevalence rates. In addition, the proportion of the adult sub-sample in each district that was classified as socioeconomically disadvantaged was mapped. 


\section{Research Findings}

Both infectious and non-communicable diseases are present in South Africa (Table 1), thereby supporting a protracted-polarised model of epidemiological transition. The findings showed a high burden of hypertension, an NCD that is increasing in prevalence with time at all spatial scales and is strongly associated with age and obesity, and with diabetes in multimorbidity cases. The infectious diseases of TB and HIV were found to be low in prevalence relative to the reported hypertension and diabetes prevalence. However, through careful examination of the findings, one can conclude that self-reported HIV and TB within the NIDS has been underreported by respondents, thereby resulting in the underestimation of these infectious diseases in South Africa at all spatial scales.

\begin{tabular}{|l|c|c|c|r|}
\hline \multicolumn{3}{|c|}{2008 - Wave 1 (age-adjusted) } & \multicolumn{2}{c|}{$\begin{array}{c}\text { 2012 - Wave 3 (age- } \\
\text { adjusted) }\end{array}$} \\
\hline $\begin{array}{l}\text { Estimated } \\
\text { Prevalence (\%) }\end{array}$ & $\mathbf{9 5 \%} \mathrm{Cl}$ & $\begin{array}{c}\text { Estimated } \\
\text { Prevalence (\%) }\end{array}$ & $\mathbf{9 5 \%} \mathrm{Cl}$ \\
\hline Hypertension & $22.73 \%$ & $(22.13-23.34)$ & $32.14 \%$ & $(31.49-32.79)$ \\
\hline Diabetes & $2.81 \%$ & $(2.58-3.06)$ & $2.71 \%$ & $(2.49-2.94)$ \\
\hline Tuberculosis & $1.59 \%$ & $(1.42-1.78)$ & $0.59 \%$ & $(0.49-0.71)$ \\
\hline HIV & $1.11 \%$ & $(0.97-1.27)$ & $2.13 \%$ & $(1.93-2.34)$ \\
\hline Multimorbidity & $2.73 \%$ & $(2.50-2.98)$ & $2.84 \%$ & $(2.61-3.08)$ \\
\hline
\end{tabular}

Table 2 Age-adjusted prevalence estimates and 95 per cent confidence intervals (CI) for the South African adult population for 2008 (wave 1) and 2012 (wave 3) using the NIDS.

The disaggregation of health data to the sub-national level revealed interesting variations in epidemiological profiles between geographies, particularly between the urban informal and urban formal areas. The urban informal and urban formal areas of South Africa are known to differ substantially in a number of aspects, including household income, socioeconomic status, as well as in general levels of health and service provision (Del Mistro \& Hensher, 2009; Daniels et al., 2013; Wabiri \& Taffa, 2013). It is likely that these settings will experience different levels of health and a different rate of epidemiological transition. Therefore, it is argued that Omran's epidemiological transition theory should be applicable at sub-national levels. Furthermore, the inconsistent burden of disease that was found between spatial scales also supports the argument for the need of data disaggregation by key characteristics and spatial scales.

Multimorbidity increased in prevalence from 2.73 per cent to 2.84 per cent in adults between 2008 and 2012 and was associated with age, socioeconomic deprivation, obesity and urban areas, while the spatial analysis showed clusters (hot spots) of higher multimorbidity prevalence in parts of KwaZulu-Natal and Eastern Cape (Figure 1), which compared with the socioeconomic disadvantage spatial pattern. However, it is likely that the district level may have been too expansive to truly represent the spatial differences in socioeconomic status and multimorbidity.

These spatial differences are likely to be more discernible at a smaller spatial scale. However, 
due to limitations around the use of secure data of NIDS, no analysis was able to be performed below the national district level. This highlights the need for data disaggregation on health to smaller spatial scales. It is likely that multimorbidity is also driven by a relationship between HIV and TB, yet the nature of self-reported health data makes this difficult to investigate due to stigma around having these health conditions.

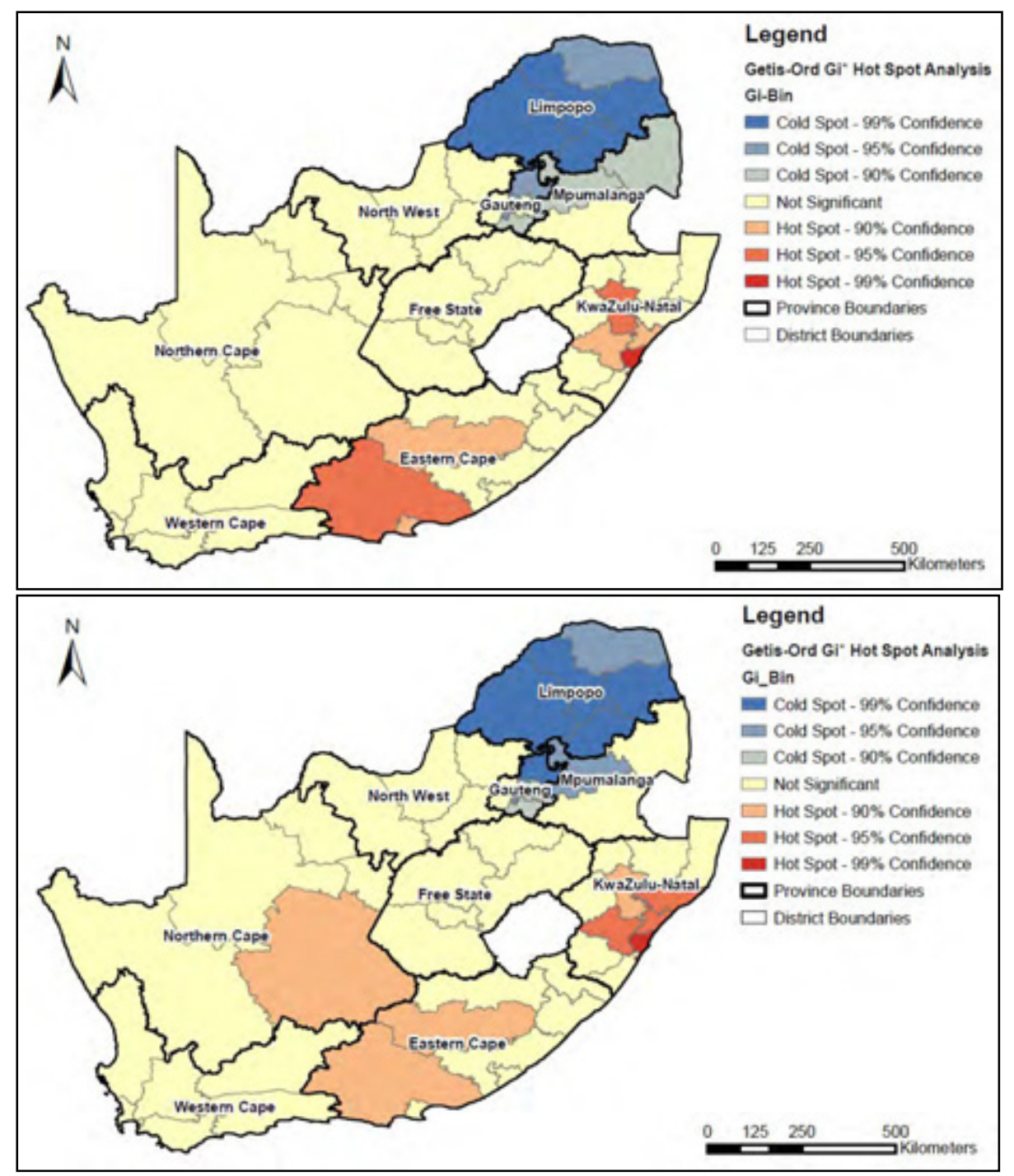

Figure 1. Getis-Ord Gi* hot spot analysis of the age-adjusted prevalence of multimorbidity in the NIDS South African adult sub-sample by district for 2008 (top) and 2012 (bottom)

\section{Conclusion}

This study used a combination of both epidemiological and spatial tools to generate new spatial and temporal knowledge of the prevalence of multimorbidity and hypertension in South Africa and has provided a baseline investigation on the association between multimorbidity and socioeconomic disadvantage at the national level. This study has entered into a conversation around the need for data disaggregation down to a city level, which enables one to study health variations below the national level and across key characteristics. Furthermore, this study has drawn attention to the concern of utilising self-reported data, particularly in monitoring HIV and TB. Lastly, the results of this study may be used to inform 
and promote healthy public policies that support the prevention and control of prevalent diseases and risk factors in the population and has provided a platform for future local level research and insight into the socioeconomic determinants of disease multimorbidity within a developing country.

\section{References}

Adato, M., Carter, M. R., \& May, J. (2006). Exploring poverty traps and social exclusion in South Africa using qualitative and quantitative data. The Journal of Development Studies. 42(2), 226-247. https://doi.org/10.1080/00220380500405345

Alaba, O., \& Chola, L. (2013). The social determinants of multimorbidity in South Africa. International Journal for Equity in Health, 12(1):63. https://doi.org/10.1186/1475-9276-1263

Ataguba, J. E. (2013). Inequalities in multimorbidity in South Africa. International Journal for Equity in Health, 12(1):64. https://doi.org/10.1186/1475-9276-12-64.

Bradshaw, D., Groenewald, P., Laubscher, R., Nannan, N., Nojilana, B., Norman, R., ... Johnson, L. (2003). Initial burden of disease estimates for South Africa, 2000. South African Medical Journal, 93(9):682- 688. https://doi.org/10.7196/SAMJ.2327

Daniels, R. C., Partridge, A., Kekana, D. \& Musundwa, S. (2013). Rural livelihoods in South Africa (Working Paper Series No. 122). Cape Town: Southern Africa Labour and Development Research Unit, University of Cape Town. Retrieved from http://www.nids.uct.ac.za/publications/discussion-papers/wave-3-papers/183-rurallivelihoods/file

Del Mistro, R., \& Hensher, D. A. (2009). Upgrading informal settlements in South Africa: policy, rhetoric and what residents really value. Housing Studies, 24(3), 333-354. https://doi.org/10.1080/02673030902869279

Eyles, J. (1985). Senses of place. Warrington: Silverbrook Press.

Omran, A. R. (1971). The epidemiologic transition: A theory of the epidemiology of population change. The Milbank Memorial Fund Quarterly, 49(4), 731-757. https://doi.org/10.1111/j.1468-0009.2005.00398.x

Tseng, A., Seet, J. \& Phillips, E. J. (2014). The evolution of three decades of antiretroviral therapy: challenges, triumphs and the promise of the future. British Journal of Clinical Pharmacology, 79(2), 182-194. https://doi.org/10.1111/bcp.12403.

Wabiri, N., \& Taffa, N. (2013). Socio-economic inequality and HIV in South Africa. BMC Public Health, 13(1):1037. https://doi.org/10.1186/1471-2458-13-1037 


\section{Urban Public Finance: A Case Study of Kisumu}

Liza Cirolia; African Centre for Cities

Urban public finance is a hidden force shaping cities and their development. This thesis draws attention to the powerful insights which can be gained from studying cities through a fiscal lens. It argues for an interdisciplinary and relational approach which infuses the fiscal study of cities with political and social interpretations of urban dynamics.

Accounting for the city through two very different registers, this thesis draws from urban public finance and from critical scholarship on urban infrastructure. The conventional urban public finance literature is largely technical, produced by urban policy and fiscal experts. In contrast, social and political theorisation on urban infrastructure provides a critical reading of the technicist approach and contributes to the refinement of key theoretical concepts within urban studies. There is incommensurability between these two scholarly registers. They have different framings of politics, technical knowledge, and the priorities for change. However, there are several shared interests. They are both concerned with urban institutions, urban places, and the necessity for change.

These shared interests provide the foundation for a revised approach to the fiscal study of cities. This synthetic approach is spelled out in a series of conceptual and methodological propositions. The first proposition is the device of the C/city, which distinguishes between an urban settlement (the small c- city) and its governing authorities (the big-C City). The C/city device foregrounds the importance of the city, the City, and the fiscal relationships which operate at the intersections between them. The second proposition frames urban public finance not just as a means of financing urban infrastructure but as an infrastructure itself. Drawing from the infrastructure scholarship, the concept of 'configuration' is deployed here creatively to trace fiscal histories, instruments, and relationships. The third proposition is the importance of grounding inquiry in particular places. To address this, the case study method is used. The case method allows for the use of a variety of types of data and analytical tools, grounded in contextualised experiences. The forth proposition presents Kisumu, a secondary city in Kenya, as an exemplary case for exploring fiscal C/city configurations.

Kisumu provides a useful case for wider generalisation precisely because it is an ordinary city. The bulk of this thesis is dedicated to unpacking the Kisumu case. First, there is a focus on the City. This includes tracing the historical development of Kisumu's urban institutions and unpacking the ways in which the contemporary City shapes and is shaped by public finance. This is followed by a deeper exploration of particular city infrastructures and their fiscal configurations. The fiscal configurations related to property rates, the corporatised water utility company, and transport finance are traced and exposed. 
The Kisumu case provides a series of valuable insights. First, it demonstrates the potential and limitations of conventional fiscal analysis. The limitations posed by accounting are particularly important in the context of Kisumu, where the C/city has many misalignments. Second, it makes the case for reading public finance as an urban infrastructure. The process of tracing fiscal configurations illuminates the social, political, material and technical dimensions of public finance. Third, it draws attention to the de facto challenges and complexities related to decentralisation. This includes how the sub-national urban state is constructed and deconstructed, over time and in complex ways. Fourth, it foregrounds the fiscal functionaries whose practices shape the everyday operations of the public finance system. These actors shape fiscal configurations. However, they are often hidden in conventional fiscal analyses. Fifth, it reads the practices of fiscal functionaries as a micropolitics of the state. The heterogeneity of the state and multidimensional nature of power are foregrounded.

Finally, the case highlights the challenge of urban infrastructure finance in the context of a post-networked city. It shows the necessity of moving beyond common academic and policy tropes related to infrastructure and services. Collectively, these insights are relevant to both the field of urban studies and public finance, providing a compelling case for deeper engagement with the fiscal C/city. 


\section{Urban transformation in the Pearl River Delta}

Chetan Kulkarni; University of Texas at Austin

The Pearl River Delta (PRD) region, in south China, is a result of the unification of eleven cities into a single megacity. The natural evolution of ecological and hydrological processes in the delta plain has been disrupted by rapid infrastructure and urban planning of land resources. This change in the delta region is characterised by rampant urbanisation of the countryside, increased industrial activity, designation of Special Economic Zones (SEZs) for increased port activity, and merging of infrastructural and telecommunication networks. Historically, the Canton province planned infrastructure for water resources, such as the canal networks for provision of water supply and trade of goods, and a dike-pond system for agriculture. Indigenous water systems in the water-rich province sufficed the needs of the population. However, rapid urbanisation and population growth in the past three decades has disrupted the natural extents of river flow, disconnected tributaries, created saltwater intrusions in fresh water reservoirs and reduced the spread of delta watershed boundaries. As a solution to the negative effects of large-scale zoning in urban development, this article investigates the emergent urban forms through an overlay process with hydrological and geological evolution of the delta plain. As the economy transforms from a trade-based agglomeration into a service-oriented hub for knowledge production and innovation, the forms of urban development must be cemented within a hydraulic structure of city planning. With findings from inundation studies of the digital elevation models and primary research documentation through field visits to cities in the PRD region, the paper aims to propose urban design principles for sustainable urban development and sustenance of the delta plain.

\section{Introduction}

The PRD region, located in south China, is an urban agglomeration formed through unification of eleven cities, including special administrative regions of Hong Kong and Macau. The largescale planning of industrial and manufacturing activity and port operations transformed the predominantly agricultural region into the world's largest urban agglomeration of 120 million people. Each city in the delta region therefore acts as a node for an extended geography of networks and systems beyond its individual urban limits. Due to the increase in number of immigrants, the local realities in the city are a mixed expression of provincial Cantonese culture that coexists with new regional as well as global cultures.

The transformation of Canton countryside into the present megacity is a process of an ancient 'hydraulic society' in rapid transition. Historically, the geographic and administrative unification of provinces in China increased the political need for navigation through a physical unit of water system, the canals. The promulgation of this thought in political leadership meant an increase in the state's organisational power to build them. However, the government policy of economic autarchy made Guangdong's access to the ocean irrelevant. In the late 1980s, Deng Xiaoping's open door policy radically changed the economy of the 
province as it was able to take advantage of its access to the ocean, proximity to Hong Kong, and its historical links to overseas Chinese population.

Over the last three decades, rapid urban transformation took place by annexing the close-knit rural settings into urban zones. Many existing and functioning rural communities became part of urban areas in a short time, forcing them to adapt their lifestyle. This phenomenon observed in the PRD, known as 'villages in the city', or the urban village, is a product of the conflict between the rapid urbanisation caused by the market economy, and of China's urbanrural dualistic registration system, or hukou. The built environment of Guangdong cities comprises of planned developments bordering the self-organised communities of the urban villages. In this atmosphere of imminent change, urban villages have grown as archipelagos of organic and incremental development. The models of urban development that are applied to city fabric fail to address local needs and demands.

This will have major consequences over the nature of urban development vis-a-vis deltaic transformation. The paper aims to present a new way to read territorial extents. Elements that currently have rigid separated boundaries on ground have coherent connections on the subsurface or atmosphere, and are exerting a mutual and fundamental influence on each other. The paper will propose strategies for coordinated urban and hydrological planning that do not intend for physical planning of space, but seek to establish potential for long-term development and sustenance of the natural earth processes.

The PRD megacity aims to keep growing by merging in peripheral cities to unlock the full potential of its geopolitical and economic strength. The underlying hypothesis to the formation of the PRD region is that by combining cities under one governing jurisdiction and increasing production capacity, it would draw in more investment, create more jobs and accelerate economic growth. Evidently, this has transformed the Guangdong countryside into a homogenous urban environment and has had major repercussions on evolution of the traditional way of inhabitation.

Many notions of sustainable urban design have been compromised. The urban and hydrological balance of bottom-up and top-down development strategies can have multiple scalar effects through the formation of cooperative communities to integrate residents with new migrants: creation of a healthy public realm to represent the complex social structure to the city. The proposed balance will be outlined in the paper through investigation of sites selected on the basis of contested boundaries, displacement of communities and introduction of new urban creations for incoming capital. This will ultimately address the participation of the public with the city and generate a sensitive and engaging relationship with the delta landscape. 


\section{Methodology}

The project inferred from the study of on-going large-scale urban and water resources planning projects, such as, South-North Water Transfer Project and the Sponge City Programme. These planning projects assume a scale that surpasses multiple regions and the implementation of the same resulted in a heavy escalation of initial project costs. The fastpaced implementation of these projects is phased in a manner that does not allow for communities of people and current ecological processes to adapt and mitigate damages. The dependence on urban zoning at a vast scale and lack of concern for taking environmental principles seriously into account has done little to ensure inclusivity of all stakeholders in the sustainable development of the delta region and its inhabitants.

Primary documentation of sites was completed through field visits to eleven urban villages in Shenzhen, Guangzhou and Zhongshan. These include the periphery of central business districts that displaced former agrarian community villages, development around rail line extensions to include peri-urban areas into the core and agrarian village clusters around reservoirs. A digital elevation model was prepared using GIS-based applications to perform deltaic analysis. Inundation level tests, terrain analysis, effects of land-use changes enable the comparative study of urbanisation and natural hydrological processes.

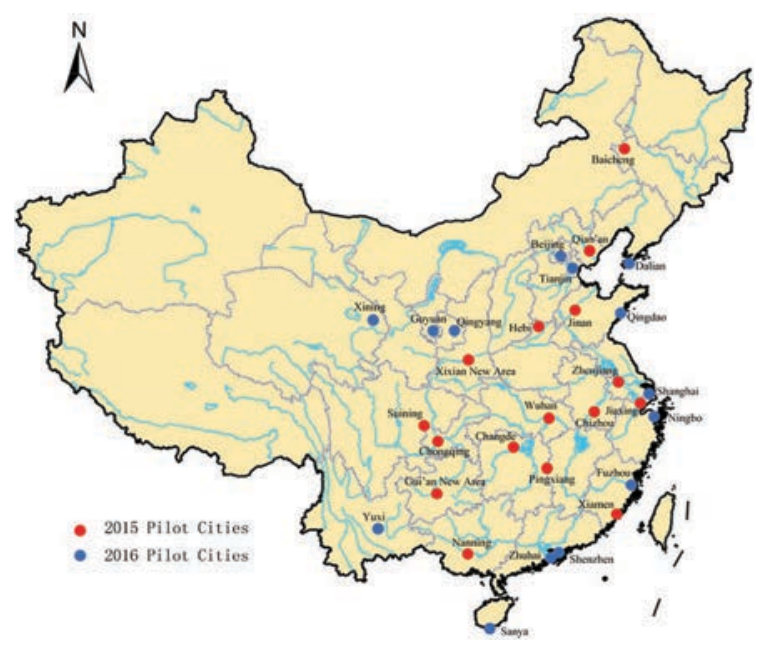

Figure 2. Location of Pilot Sponge Cities in China

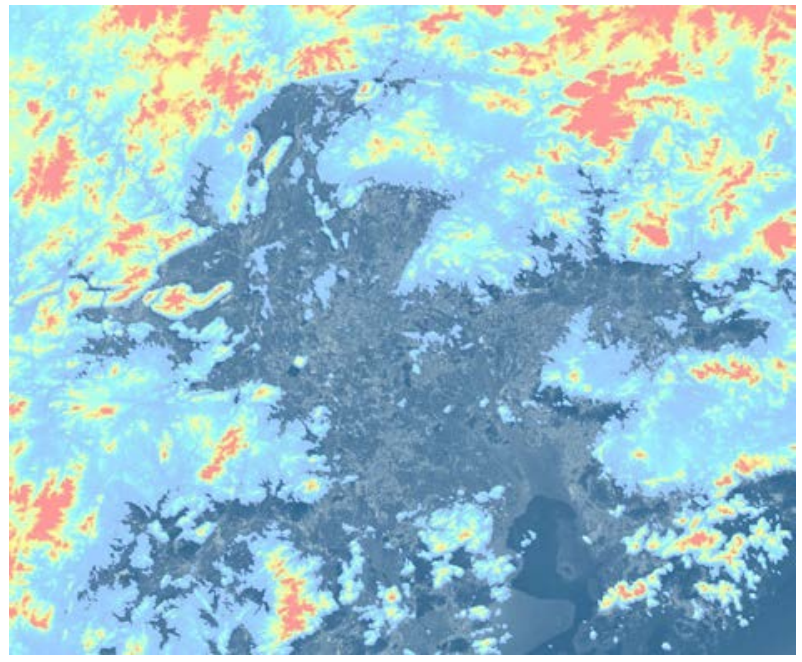

Figure 3. Digital elevation model of Pearl River Delta

\section{Findings and Discussion}

The delta sedimentation study in the PRD region juxtaposed geological layers, hydrological processes and urban district extents. The study highlighted problem conditions and indicated opportunities for creating fresh water basin by shelving tidal estuaries. The topographical information of mountainous peripheries around urbanised regions indicated encroachment of environmental risk zones. The elevation data also suggested disruption of water flows through the introduction of flood-gates to channelise natural flow of water streams to occupy the river edges. The digital elevation model illustrated the urgent need to respond to increasing levels of south China sea-level rise. 
The Guangdong province immensely profited from access to the ocean for port operations after Deng Xiaoping's economic reform policy. However, the unplanned consequences of infrastructure development has disturbed the aquifer transfers and led to saltwater intrusions, creating urgency for organising fresh water transfers from upstream locations. The model is expected to show the gaps in the urban fabric of cities in order to connect and repair the disruptions of river systems.

The coastlines of the PRD have been modified for protection against coastal erosion by building of artificial beaches and islands, reclamation for aquaculture and agriculture, and the construction of harbours. (Chen, 2002). These efforts must be coordinated in a large-scale soft infrastructure planning to regulate urban planning with hydrological system planning.

\section{Conclusion}

The paper aims to present urban design principles based on the overlay analysis of regional and urban elements with natural evolutionary processes of the delta basin. The role of the design is not to propose new urban clusters but to integrate development measures into thriving environmental processes. The proposed expansion of the PRD region into peripheral cities will certainly coincide with environmentally sensitive zones. It demands an overlap of urban design strategies with hydrological measures to ensure the shaping of new urban form in planned resilience from environmental risks.

While the local conditions were documented and data trends synthesised into observations, this paper does not study national and global influences on the PRD region or its economy. It does not account for the role of soft power and media in transforming the conventionally accepted ways of living, working and consuming resources. The paper aims to include speculative changes, such as milder zoning principles that may help to solicit representation in the process of governmental decision-making for urban development, displacement and future planning.

The PRD region centres its future economic growth on new urban clusters for knowledge production and innovation. This will create a consequent need for increasing housing stock and related amenities. The principles outlined by the paper will address spatial impacts of this on the emergence of unique urban forms, formation of new social structures as the per capita incomes rise, and inform modulation of geographical terrain due to infrastructural development.

Keywords: Pearl River Delta; megaregion; hydrology; urbanisation; sustenance 


\section{References}

Bolchover, J., \& Hasdell, P. (2016). Border ecologies: Hong kong's mainland frontier. Basel: Birkhauser.

Bruyn, J. D., Acker, M. V., Buyse, F., Rasier, F., \& Abeele, P. (Eds.). (2014). In via veritas: Route as paradigm for urbanism. Mechelen: Public Space.

Chen, J., Eisma, D., Hotta, K., \& Walker, H. J. (Eds.) .(2002). Engineered coasts. Berlin: Springer Science+Business Media, (pp. 45-55).

Chow, R. Y. (2015). Changing chinese cities: The potentials of field urbanism. Honolulu: University of Hawaii Press.

Chung, C. J., Inaba, J., Koolhaas, R., \& Leong, S. T. (2002). Great leap forward: Harvard design school project on the city. Koln: Benedikt Taschen Verlag.

Li, H., Ding, L., Ren, M., Li, C., \& Wang, H. (2017). Sponge city construction in China: A survey of the challenges and opportunities. Water, 9(9), 594. https://doi.org/10.3390/w9090594

Mars, N., \& Hornsby, A. (2008). The Chinese dream: a society under construction. Rotterdam: 010 Publishers.

O'Donnell, M. A. (1999). Path breaking: Constructing gendered nationalism in the Shenzhen special economic zone. positions: east asia cultures critique, 7(2), 343-375.

Sarkis, H. (2017). The world in the architectural imaginary. In D. Daou \& P. Pérez-Ramos (Eds.), New geographies 08: Island. Cambridge, Massachusetts: Harvard University Press.

Wittfogel, K. A. (1981). Oriental despotism: A comparative study of total power. New York: Vintage Books. 


\section{Urbanisation in monsoon Asia and the agrarian question}

Stephen Cairns; Future Cities Laboratory/ETH Zürich

This paper examines recent debates on urbanisation, focussing on critiques of city-centric conceptions of urbanisation, to argue that important theoretical reorientations are required to appropriately address the hybrid urban-rural conditions that typify patterns of urbanisation in many parts of Asia. It argues that to achieve this, new inter-disciplinary alignments between urban studies and agricultural science and planning, and methodological innovations and ways are seeing are required. The first part of the paper delves more deeply into the critiques of city-centric urbanisation. The paper then goes on to consider the theoretical legacy of agricultural science and planning, before outlining emerging ways of seeing that support research on hybrid urban-rural conditions. A final section illustrates a range of methodological experiments being developed by the urban-rural systems research team at the Future Cities Laboratory (FCL) in Singapore that aim to refine such an approach.

\section{Extract from Cairns 2018}

A dominant and influential formulation of urbanisation regards it as a city-centric process, the definitional heart of which is 'the concentration of populations in cities' (UN 1969; UN 1997; UN 2010). This is evident in many policy frameworks. The Sustainable Development Goals (SDGs), the Paris Agreement (United Nations Convention on Climate Change), and the New Urban Agenda (Habitat III), to take just three recent formulations from global intergovernmental organisations, all regard the city as the defining end point and causal engine of urbanisation. The city's concentration of population, goods, services, capital and ideas generates diversified employment, education and life opportunities, which in turn attract aspirant urbanites from rural areas.

This city-centric perspective on urbanisation enjoys remarkable consensus and often forms the basis for long-term sustainable development. For example, each of the United Nationsfacilitated frameworks already mentioned help set priorities not only for government agencies at all scales, but also multilateral development banks, civil society groups and industries. Although separate initiatives, they cross-reference each other and use mutually recognisable vocabularies to articulate complementary and overlapping agendas that draw on shared forms of evidence on demographic, economic and environmental conditions. Each framework points to the positive correlation between urbanisation rates and economic growth, as well as the potential threats that unmanaged urbanisation poses to environmental sustainability. Securing the benefits and ameliorating the threats of urbanisation, according to these convergent frameworks, is a matter of foregrounding the effects of concentrating and concentrated city settlement types.

The policy directions that can follow from such a city-centric understanding of urbanisation 
often prescribe intensification of city settlement: dense, compact, accessible and mixed-use city types. The Intergovernmental Panel on Climate Change (IPCC) report accompanying the Paris Agreement, for instance, marshals abundant scientific evidence to argue that such intensified city typologies not only reduce greenhouse gas emissions but also enhance overall economic and social vitality (Seto et al. 2014, 955-56). Similarly, the New Urban Agenda, an output of the Habitat III conference held in Quito in 2016, calls for 'appropriate compactness and density, polycentrism, and mixed uses' (no. 49), to 'prevent urban sprawl, to reduce mobility challenges [...] and to harness density and economies of scale and agglomeration' (no. 98). While the SDGs advocate using the 'ratio of land consumption rate to population growth rates' as one indicator of progress towards the goal of sustainable urbanisation (no. 11), all three frameworks regard themselves as 'universal' agendas for development which articulate, in varying ways, the economic, social and environmental benefits that cities can deliver.

Yet the rise of this city-centric consensus in global intergovernmental policy circles coincides with a persistent scholarly wariness about the usefulness of the city as a conceptual unit when thinking about what urbanisation is and how to intervene in its effects, be they positive or negative. In recent years, this caution has hardened around two distinctive critiques of citycentricity. The first is more empirical in character and focusses on the physical expansion of cities and the attendant difficulties with consistently categorising and measuring their built, demographic and economic footprints. The second is more theoretical in character and argues that cities, as physical and social spaces, are merely one expression of a process of urbanisation that stretches to the surrounding region and beyond. We might think of this scholarship as replacing 'the city' with 'urbanisation effects', which of course appear in the city settlement, but also at a distance from the city itself. A non-contiguous, networked and extended concept of urbanisation has a long lineage in urban studies and planning. It is manifest in, for example, the geographical framing of planning as 'urban and regional', but also in Friedman's world-city hypothesis (Friedman, 1986), as well as the more recent, and thoroughly up-scaled concept of 'planetary urbanisation' (see Brenner, 2013; Brenner and Schmid, 2014; Rickards et al., 2016; Gandy, 2012).

Urban conditions as they exist in Monsoon Asia have historically played an important role in thinking about urbanisation beyond city limits. Notable in this respect is the work of Terry McGee (1987; 1991), which brought scholarly attention to the interaction between urbanisation and intensively populated, rice growing, rural areas surrounding cities in Indonesia and other parts of Asia. He discerned a hybrid urban-rural, or desakota (Indonesian for village-city), landscape. One of the more suggestive legacies of McGee's analysis is to point to a settlement typology and process in which the rural is not simply in a state of momentary transition to a fully urban state. His hybrid concept implies that a densely populated rural area is amenable to sustaining urbanised logics, even while they remain rich, food producing territories or vital hydrological hinterlands. 
Focussing on urbanisation in Monsoon Asia with this analytical lens can sensitise scholarship, policy making, design and planning practice to the potential of hybrid rural-urban conditions in the shaping of viable urbanisation pathways, in Monsoon Asia and beyond. McGee's original notion of desakota was valuable because it placed into question certain developmentalist assumptions which assumed that rural areas on the fringes of cities would inevitably give way to urbanisation fully formed. The notion of planetary urbanisation has also been valuable because it questioned the limits of seeing urbanisation through the city form, reminding us that much of what happens outside cities is done in the name of the urbanisation growth machine. But to conclude that everything is now in the service of urbanisation, does not mean that we can or should always assume that settlement conditions that are non-city in type or logic are urban in intent or destiny. To conclude this would be to effect a conceptual, if not actual, colonisation of all that was not city in the name of urbanisation. What price would be paid for such an elision? What existing resources for alternative ways of living, settling and producing might be lost if we see the world only through the lens of planetary urbanism?

Take, by way of example, the contradictory position we find ourselves currently in. At least one strand of persuasive theory tells us that everything is now (one way or another) urban, but dominant policy and planning interventions in cities worry away incessantly at keeping the urban footprint compact and dense as if there is still a non-urban condition to protect and preserve. Of course, what this apparent contradiction reintroduces us to is the fallacy of settlement as an indicator of urbanism. Those seeking to design compact cities are not just protecting geographically proximate rural hinterlands which might be encroached upon, but also temporally and geographically distant resources that might be preserved if the energy demands of a city were reduced. So, how do we proceed as urban theorists and practitioners in a way that neither reifies the city as built footprint, implying that settlement typology is meaningless, nor turns everything into an abstract calculation of resource exploitation?

It is the argument of this chapter that looking at urbanisation in Southeast Asia sensitises scholarship and worlding practices to the possibilities of urban-rural hybrids or so-called desakota conditions. These include seeing them not simply as transitional landscapes en-route to being cities, nor merely as hinterlands serving a globally pervasive urban appetite, and even discerning in them viable alternative modes of settlement. Developing these possibilities requires, in the first instance, that desakota conditions are viewed for their own intrinsic worth which transpires precisely from the fact that they are neither fully urban nor fully rural. This poses a set of methodological and measurement problems, problems which we might characterise as being about way of sensing, whether they are remote or intimate. 


\section{References}

Brenner, N. (2013). Theses on urbanization. Public Culture, 25, (1 (69)), 85-114. https://doi.org/10.1215/08992363-1890477.

Brenner, N., \& Christian, S. (2014). The urban age in question. International Journal of Urban and Regional Research, 38(3), 731-55. https://doi.org/10.1111/1468-2427.12115

Cairns, S. (2018). Debilitating city-centricity. In R. Padawangi (Ed.), Routledge handbook of urbanization in Southeast Asia. London: Routledge.

Department of Economic and Social Affairs. (1969). Growth of the world's urban and rural population, 1920-2000 (Population studies. No. 44). New York: United Nations. Retrieved from

https://population.un.org/wup/Archive/Files/studies/United\%20Nations\%20(1969)\%20\%20Growth\%20of\%20the\%20World's\%20Urban\%20and\%20Rural\%20Population,\%2019 20-2000.pdf

Friedmann, J. (1986).The world city hypothesis. Development and Change, 17(1), 69-83. https://doi.org/10.1111/j.1467-7660.1986.tb00231

Gandy, M. (2012). Where does the city end. Architectural Design, 82(1),128-133. https://doi.org/10.1002/ad.1363

McGee, T . G. (1987). Urbanisasi or kotadesasi? the emergence of new regions of economic interaction in Asia. Honolulu: East-West Environment and Policy Institute.

McGee, T. G. (1991). The emergence of desakota regions in Asia: Expanding a hypothesis. In N. Ginsburg, B. Koppel \& T. G. McGee (Eds.), The extended metropolis: Settlement Transition in Asia. Honolulu: University of Hawaii Press.

Rickards, L., Gleeson, B., Boyle, M., \& O'Callaghan, C. (2016). Urban studies after the age of the city. Urban Studies, 53(8), 1523-1541. https://doi.org/10.1177/0042098016640640.

Solecki, W., Seto, K. C., \& Marcotullio, P. J. (2013). It's time for an urbanization science.

Environment: Science and Policy for Sustainable Development, 55(1),12-17.

https://doi.org/10.1080/00139157.2013.748387

United Nations. (1997). Glossary of environmental statistics, studies in methods (Series F. No. 67). New York: United Nations. Retrieved from https://unstats.un.org/unsd/publication/SeriesF/SeriesF_67E.pdf

United Nations DESA/Population Division. (2009). World urbanization prospects: The 2009 revision highlights. New York: United Nations. Retrieved from https://wedocs.unep.org/bitstream/handle/20.500.11822/18401/World_Urbanization_pr ospects_2009_Revision.pdf?sequence=1\&isAllowed=y

United Nations DESA/Population Division. (2014). World urbanization prospects: The 2014 Revision. New York: United Nations. Retrieved from https://esa.un.org/unpd/wup/Publications/Files/WUP2014-Report.pdf

United Nations (1969) 'Growth of the world's urban and rural population, 1920-2000', Population Studies no. 44, New York: United Nations, Department of Economic and Social Affairs.

United Nations (2010) World Urbanization Prospects: The 2009 Revision, New York: United Nations, Department of Economic and Social Affairs, Population Division. 



\section{A regional variant of Silicon Valley? Bangalore's role in the innovation networks of the global information economy}

Balaji Parthasarathy; International Institute of Information Technology, Bengaluru

A third industrial revolution, driven by micro-electronics based Information and Communication Technologies (ICTs), has emerged in the latter half of the twentieth century. Especially with the development of the microprocessor in 1971 it blossomed most prominently in Northern California's Silicon Valley (Parthasarathy and Lage, 2010). ICTs offer the ability to digitise, or encode as streams of bits: inputs such as text, images, and speech. As technological advances have made them increasingly powerful, and declining marginal costs of production have made them more affordable, ICTs have made it easier to obtain and deliver vast amounts of information from and to any corner of the world, in real time, on a scale unparalleled in history,

The new industrial revolution blossomed during a crisis in the welfare states of the global North and the disappointing economic record in much of the global South (such as in India) (Castells, 2000). These conditions created an intellectual climate for the ascendance of the Washington Consensus, which set aside statist development models in favor of free markets, private property, and individual incentives, and the liberalisation of external trade and capital movements (Gore, 2000). A more open international trading regime, institutionalised in the form of the World Trade Organization, was simultaneously facilitated by ICTs, and laid the foundation for an 'informational, global and networked' economy (Castells, 2000).

The economy is informational as the productivity and competitiveness of its units depend on their capacity to 'generate, process and apply efficient knowledge based information'; it is global as 'its core activities of production, consumption and circulation are organised and generated on a global scale either directly or through a network of linkages between economic agents'; and it is networked as 'its productivity is generated through and competition is played out in a global network of interaction between business networks' (Castells, 2000:77-78). This economy is capable of applying 'its progress in technology, knowledge, and management to technology, knowledge, and management themselves. Such a virtuous circle should lead to greater productivity efficiency, given the right conditions of equally dramatic organisational and institutional changes' (ibid.).

While the potential of the global economy, and the technological conquest of physical distance, has fuelled speculation about the 'death of distance' (Cairncross, 1997), or that the 'world is flat' (Friedman, 2005), the socio-spatial unevenness that has historically characterised capitalism remains in evidence (Harvey, 2006). Far from reducing social inequities, informational capitalism is highly selective in 'connecting localities throughout the planet, according to criteria of valuation and devaluation enforced by social interests that are dominant in these networks' (Castells, 2002). In other words, while to formal information 
theory '. . . the semantic aspects of communication are irrelevant to the engineering aspects' (Shannon and Weaver, 1964), information becomes knowledge only when it is used to present '... a reasoned judgment or an experimental result, which is transmitted through some communication medium in some systematic form' (Bell, 1999). Thus, upholding the truism that knowledge is power requires a social context to understand the structure and meaning of information.

This abstract argues therefore that, while the ability to build ICTs to obtain and deliver information is a necessary condition for any locality to insert itself into the contemporary global economy, the sufficient condition is the knowledge of how this versatile basket of general purpose technologies can be deployed in various socio-economic domains ranging from banking to healthcare to manufacturing. The abstract also argues that the socio-spatial unevenness arising from the differential ability to build and deploy technology can be understood in terms of institutional governance, especially how firms are conferred global competitive advantage by the territorially bound comparative advantage that states construct. It is against this backdrop that this abstract will discuss India's emergence as the world's largest software services exporter, centred round Bengaluru, as an analytical case.

Post-1947 India's adoption of autarkic, public-sector driven, import-substitution industrialisation (ISI) policies, along with a 'license raj, permit raj' regulatory regime, discouraged entrepreneurship, innovation, foreign investment, and resulted in a disappointing 'Hindu rate of growth'. (Sridharan, 1996). Consequently, industrial policy, which was used as the primary tool for regional development, proved blunt. Further, although the location of public sector enterprises (PSEs), which occupied the 'commanding heights of the economy', were often decided on political grounds for 'spatially balanced' development, industry tended to concentrate in states with better physical and social infrastructure (Parthasarathy and Mohan, 2013). This only demonstrated an inadequate appreciation of nurturing a nexus of traded and untraded dependences between producers, customers, and providers of business services in various economic sectors, instead of relying on spatial proximity alone to unleash the propulsive forces of Perrouxian growth poles, or harness agglomeration economies (Storper, 1995).

In the early 1980s, acknowledging that India had not enjoyed the economic prosperity of 'lateindustrialisation' in countries such as South Korea or Taiwan, changes in economic policy were cautiously initiated (Sridharan, 1996). The changes have been pursued with less inhibition since 1991 when a balance of payments crisis forced a devaluation of the rupee, induced trade liberalisation and greater openness to foreign investment, and a New Industrial Policy reduced entry barriers and regulations for firms.

Alongside these changes in India, the blossoming of the ICT revolution was characterised by the phenomenon of 'convergence'. Convergence refers to the tendency of software to increasingly determine the cost and functional characteristics of all semiconductor-based 
equipment, whether computers, telephone switches, or audio systems. But since the production of reliable software has proven labour-intensive (Brooks, 1995), there were pressures for the globalisation of its production to overcome a shortage of skills in the global North. This triggered a wave of offshoring and opened 'windows of locational opportunity' (Storper and Walker, 1989) for locations that could offer a competitive skill to cost ratio.

It was at this historical juncture that India stepped in to provide skilled but relatively low-wage software professionals. ${ }^{1}$ Despite widespread illiteracy, the expansion of the higher education system meant that India graduated more science and technology personnel than most other countries. Unleashing the potential of the personnel, many of whom were either unemployed or underemployed during the years of ISI, resulted from key policy initiatives undertaken for the software industry since the mid-1980s to ensure that India had greater exposure to the technologies sweeping the world (Subramanian, 1992). A major policy initiative was the establishment, in 1990, of Software Technology Parks (STPs) which were export zones dedicated to the software industry. In addition to financial incentives, the STPs also offered crucial data communication facilities. Indian firms capitalised on the STPs to pioneer a Global Offshore Delivery Model, by establishing software factories with the technology, quality processes, productivity tools, and methodologies of the customer workplace.

Within India, locating one of the earliest STPs in Bengaluru reinforced another advantage that the region offered firms: skilled labour in the PSEs in sectors such as aerospace, defense electronics, and telecommunications, subsequently replenished by the graduates of the engineering colleges of Karnataka and bordering states, which collectively account for nearly two-thirds of the nation's output of engineering students. As the region became the largest centre for software exports in the country, and home to the growing number of multinational corporations (MNCs) entering the country in the more liberal economic regime since the 1990s, Bengaluru was increasingly referred to as 'India's Silicon Valley'.

But, at least until 2000, the moniker was inappropriate, as firms in Bengaluru were primarily focussed on exports, and their ties were to customers and other firms in the main market. There was little local connection, other than with the labour market, nor was there much interaction among firms. The absence of an environment, with 'blurred boundaries' between firms, universities and other local institutions, to facilitate the sharing and circulation of ideas, and to foster a 'technical community', that characterises an innovative milieu like Silicon Valley (Saxenian, 1994), hindered the ability of firms in Bengaluru to define products and technologies.

Such an institutional environment had to wait until the internet bust at the turn of the millennium, and the research and development (R\&D) outsourcing that followed. Bengaluru took advantage of these trends once again because of the availability of human capital. Except that the human capital came not just from India, but also from those who had left the country. A 'brain drain' of skilled migrants to the US, had intensified in the 1990s as India 
became the largest beneficiary of H1-B visas, mostly for skilled ICT professionals. But, as newer options opened up at home, there were greater flows of the diaspora between India and the USA. These 21st century argonauts, and their 'brain circulation', (Saxenian, 2006) brought not just skills, but also a knowledge of global markets. Access to such embodied knowledge allowed Bengaluru to especially benefit from shifts in the organisation of production in the semiconductor industry and become a global centre for embedded systems design.

A deepening of this institutional environment has taken place in the past decade with growing emphasis on 'inclusive growth', especially to meet the needs of an estimated four billion people, earning less than US $\$ 2$ per day, at the 'bottom of the pyramid' (BoP) (Aoyama with Parthasarathy, 2016). However, meeting the needs of a population that lacks affordability; that is found in locations where physical infrastructure such as power is weak to non-existent, is not socio-culturally homogenous; and is characterised by relatively limited skills, and low levels of literacy is challenging. Thus, serving the BoP requires explicit and tacit knowledge about circumstances and lives that have hitherto received little attention.

India is sought after as a location from which to understand the BoP because of its large socially and culturally diverse population, a large proportion of which lives in poverty and illiteracy amidst inadequate infrastructure. Although such circumstances, plus an unpredictable regulatory environment and corruption in public life, can prove chaotic and challenge firms, Venkatesan (2013) proclaims, 'win in India, win everywhere'. What makes 'winning' in India more likely than anywhere else is the pool of technical skills to design and deploy ICTs to address the challenges of the BoP. Second, with a thriving civil society in the world's largest democracy, India is home to a range of NGOs which, at least partially, compensate for the state's failure to provide many social and physical infrastructures (Jenkins, 2010). It is the ability to combine the technical skills of the world's largest software services provider, with the knowledge that can come from working with NGOs, which has led firms to seek India, and Bengaluru, as a location from which to develop innovative products and services for the underserved. Firms not only serve India, but also other countries with similar conditions, including those in the global North, in a process that reverses conventional innovation flows (Govindarajan and Trimble, 2012).

This abstract discusses the implications of a global and networked economy, which is intellectually supported by current development thinking, and whose technological infrastructure is provided by ICTs. While contemporary ICTs provide the means to rapidly collect information and connect localities, integration into global production networks depends on the ability of a locality to make sense of the information flows as knowledge. Trapping knowledge, in turn, depends on institutional conditions. In the case of India, Bengaluru's comparative advantage initially came from low-wage skilled labour often trained/legitimised by the state, and with state-provided infrastructure in the form of STPS. This became the basis for the competitive advantage of firms which, after 2000 , drew on 
direct connections to markets, initially overseas, and then locally. These connections then provided the means to build the set of local dependencies to create a region that has a unique comparative advantage, and is innovative in its own right, in the global economy that cannot be reduced to a regional variant of Silicon Valley.

\section{Endnote}

1 The discussion of the Indian software industry in this paragraph, and the next three, is drawn from Parthasarathy (2010) unless mentioned otherwise.

\section{References}

Aoyama, Y., \& Parthasarathy, B. (2016). The rise of the hybrid domain: Collaborative governance for social innovation. Cheltenham, United Kingdom: Edward Elgar Publishing.

Bell, D. (1999). The coming of post-industrial society: A venture in social forecasting. New York: Basic Books.

Brooks, F. P. (1995). The mythical man-month: Essays on software engineering. Boston, MA: Addison Wesley.

Cairncross, F. (1997). The death of distance: How the communication revolution is changing our lives. Boston, MA: Harvard Business School Press.

Castells, M., \& Blackwell, C. (1998). The information age: economy, society and culture. Volume 1. The rise of the network society. Environment and Planning B: Planning and Design, 25, 631-636.

Castells, M. (2000) “Materials for an Exploratory Theory of the Network Society" British Journal of Sociology, Volume 51, Tavistock Publications

Castells, M. (2000) “The Rise of the Network Society: Economy, Society and Culture v.1: The Information Age: Economy, Society and Culture" Wiley Blackwell Publishing

Castells, M. (2002) "The Internet Galaxy: Reflections on the Internet, Business, and Society" OUP Oxford Press

Evans, P. (Eds.). (2002). Livable cities? Urban struggles for livelihood and sustainability. Berkeley, CA: University of California Press.

Friedman, T. L. (2005). The world is flat: A Brief history of the twenty-first century. New York, NY: Farrar, Strauss and Giroux.

Gore, C. (2000). The rise and fall of the Washington Consensus as a paradigm for developing countries. World Development, 28(5), 789-804. https://doi.org/10.1016/S0305750X(99)00160-6

Govindarajan, V., \& Trimble, C. (2012). Reverse innovation: Create far from home, win everywhere. Boston, MA: Harvard Business Review Press.

Harvey, D. (2006). Spaces of global capitalism: A theory of uneven geographical development. London, UK: Verso.

Jenkins, R. (2010). NGOs and Indian politics. In N. G. Jayal, \& P.B. Mehta (Eds.), The oxford companion to politics in India. (pp. 409-426). New Delhi: Oxford University Press.

Parthasarathy, B. (2010). The computer software industry as a vehicle of late industrialization: Lessons from the Indian case. Journal of the Asia Pacific economy, 15(3), 247-270. 
https://doi.org/10.1080/13547860.2010.494902

Parthasarathy, B., \& Lage, R. G. (2010). Organizational impacts of information technology. In

Bidgoli, H. (Ed.).Core concepts, financial tools and techniques, operations and innovation management. In The Handbook of technology management series (Vol. 1). Hoboken, NJ: John Wiley.

Parthasarathy, B., \& Mohan, A. K. (2013). Approaches to regional policies in India. Regions Magazine, 289, 16-18. https://doi.org/10.1080/13673882.2013.10662632

Saxenian, A. (1994). Regional advantage: Culture and competition in Silicon Valley and Routledge 128. Cambridge, MA: Harvard University Press.

Saxenian, A. (2006). The new argonauts: Regional advantage in a global economy. Cambridge, MA: Harvard University Press.

Shannon, C. E., \& Weaver, W. (1964). A mathematical theory of communication. Champaign, IL: University of Illinois Press.

Sridharan, E. (1996). The political economy of industrial promotion: Indian, Brazilian, and Korean electronics in comparative perspective 1969-1994. Westport, CT: Praeger.

Storper, M. (1995). The resurgence of regional economies, ten years later: the region as a nexus of untraded interdependencies. European Urban and Regional Studies, 2(3), 191 221. https://doi.org/10.1177/096977649500200301

Subramanian, C. R. (1992). India and the computer: A study in planned development. New Delhi: Oxford University Press.

Venkatesan, R. (2013). Conquering the chaos: Win in India, win everywhere. Boston, MA: Harvard Business School Press.

Walker, R., \& Storper, M. (1989). The capitalist imperative: Territory, technology and industrial growth. New York, NY: Basil Blackwell. 


\section{Indian univer(c)ities: Knowledge and its effects on city regions}

Kala S Sridhar; Institute for Social and Economic Change

The 2018 Nobel Prize for Economics for ideas as a driver of economic growth to Paul Romer could not have come at a more opportune time for India. Romer highlighted in his work the role of ideas and technical change in economic growth. In his 1986 article in the Journal of Political Economy, he presented a model of endogenous technical change in which the accumulation of knowledge by profit-maximising and forward-looking agents drives long-run economic growth. In this research, implicit was the assumption that knowledge/ideas are an intangible capital input in production with increasing marginal productivity. Marginal productivity increases with ideas because the production of new knowledge by one firm generates a positive externality for other firms; even if intended, knowledge cannot be kept a secret for a long period of time. The creator of such knowledge can capture its benefits, in the form of patent rights initially; however, a part of such knowledge thus generated, is available to others without compensation to the creator. Using these assumptions, Romer demonstrated that growth rates can be increasing over time, and presented long-run evidence in support of his model of growth.

India has now become increasingly a service oriented economy, with its GDP from services at an all-time high of 57 per cent of the national output. Services refer to a wide variety of sectors including retail, trade, commerce, transport, storage and communications, banking, real estate, and insurance, communications, including telecommunications. While services may imply an army of people working at hotels, restaurants, hospitality industries, what the increasing services orientation hides, is the fact that India is becoming an increasingly knowledge-based economy, whereby workers are becoming more skilled. Knowledge workers are those who need to 'think' to make a living: academics, engineers, doctors, lawyers, scientists, accountants, architects, planners and so forth. The evidence is that India has a demographic advantage in providing an increasing supply of such knowledge workers to the world.

The primary reason why cities become engines of economic growth is that they are the hubs of knowledge activity. This may be seen in the fact that while cities and factory towns are created because of scale economies, large cities and urban agglomerations are created due to the existence of agglomeration economies (Brueckner, 2011), where the benefits of economies from the co-existence of people and firms are very prominent and population and firms do not have to reinvent the wheel to start their economic activity. Large cities are also places which enable the seamless exchange of knowledge and learning, sharing and matching, which are otherwise not possible where density is low. There is evidence that patent intensity is higher in cities where the population and employment densities are higher, taking the case of US cities (Carlino et al 2007). This is also one reason which explains why we find a large number of specialised medical professionals such as otolaryngologists, 
cardiologists, ophthalmologists, oncologists, gastroenterologists, and so forth in cities, whereas in rural areas, there is typically one physician for all problems.

Drucker and Goldstein (2007) summarised empirical results which demonstrated that in the context of the US university research, teaching, and technology helped to raise regional average earnings. By virtue of their synergies, large cities also frequently become primate cities, which attract private investment, when compared with the smaller cities, except if the smaller towns also distinguish themselves in a knowledge intensive manner.

One way in which we can understand the effects of knowledge on economic development at the spatial level is to understand the linkages between academic institutions (knowledge hubs) and industry (leaders in economic development) in cities and/or regions. There is evidence that there are extensive academia-industry linkages in two Indian city regions: Bengaluru and Pune (Basant and Chandra, 2007), where it was found that there was a hierarchy of institutions satisfying the demand for a variety of skills to technologies.

In the US, needless to say, research universities have had a lot of impact on the economic development of their cities and regions. Famous examples are the effects of Stanford University on Silicon Valley and of Massachusetts Institute of Technology (MIT) on Boston Route 128, as Saxenian (1996) demonstrated.

Taking the case of China, Kafouros et al. (2015) reported an inverse U-shaped relationship between university collaborations and innovation performance, which supported the view that the overutilisation of external knowledge and technology may actually hinder a firm's innovation performance. This also suggested that over-engagement with academic institutions could be detrimental to a firm's innovation performance. Hence, firms may have been better off having fewer but more valuable academic collaborations.

In Brazil, Garcia et al. (2015) found that firms with higher absorptive capacity and larger firms tended to collaborate with research groups that were more geographically distant. On the university side, high-performance and larger research groups tended to attract firms that were, again, more geographically distant as collaboration partners. Long-distance collaborations in Brazil therefore usually occurred when firms required high absorptive capacity and when they could not find high-quality local universities.

In the context of India, Basant and Chandra (2007) examined Bengaluru and Pune which have a number of knowledge workers, and their effect on the two city clusters. They found a hierarchy of institutions respond to the demand from a hierarchy of skills. In addition to these two cities, which are undoubtedly knowledge hubs, we may consider several cities as university towns:

1. Vellore (Tamil Nadu) which has the Vellore Institute of Technology, Christian Medical College (CMC) 
2. Kota (Rajasthan) which is home to a large number of coaching institutes that train youth for various professional examinations

3. Ahmedabad (Gujarat) which is home to Indian Institute of Management (IIM), Centre for Environmental Planning and Technology (CEPT) University and several others

4. Warangal (Telangana), which has the National Institute of Technology

5. Aligarh (Uttar Pradesh), home to the Aligarh Muslim University

6. Baroda (Vadodara) (Gujarat), which is home to the MS (Maharaja Sayajirao) University of Baroda, which has roughly 100,000 students enrolled

7. Manipal, Karnataka, which has the Manipal Institute of Technology, the Kasturba Medical college and affiliated institutions as part of the Manipal Academy of Higher Education

8. Dharwad (Karnataka) which is considered a hub of knowledge, with several academic institutions including Karnatak University; University of Agricultural Sciences; IIT- Dharwad; Indian Institute of Information Technology, Dharwad; and Centre for Multidisciplinary Research, among others.

The above towns are also geographically representative of the entire country, located in the north, west, south and eastern parts of India. There are several indicators that can be used to understand the economic base of a city/town. Location quotients which indicate the comparative advantage of a city in a particular industry in relation to a reference region are the simplest of them.

Mathematically, as Sridhar (2016) defines the location quotient (LQ) for a town, which helps one to understand the economic base of a town, is denoted below.

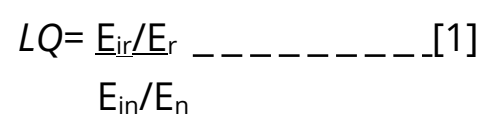

In equation [1], $E_{i r}=$ Employment in sector $\mathrm{i}$ of city $r$, and $\mathrm{Er}$ is total employment of city $r$; $E_{i n}=$ Employment in sector $i$ of the reference area (the state or the country), and $E_{n}$ is total employment in the reference area (the state or the country).

Based on equation [1], if $L Q>1$ then the sector in question is an export industry; if $L Q<1$, then the sector in question, is an import industry. This is because LQ>1 means that the industry employs a greater share of local workforce than it does nationally, which implies that the industry is producing more than what is consumed locally. If $L Q<1$, it means that local residents and businesses are purchasing goods and services from outside the local area.

While based on the LQ analyses, using the nation as reference, Sridhar (2017) found that Mumbai is the financial capital of India, Delhi is the seat of public administration, and Bengaluru is specialised in transport, storage and communications, in which presumably 
information technology is included. The location quotients (LQS) for selected university towns for the latest year for which the data is available are reported. The hypothesis in the context of this paper is that the LQs of university towns will be greater than 1 as it relates to knowledge-based industries. Further, knowledge will have its multiplier effects on other sectors, in the sense that in university towns, faculty and students are the centre of the economic activity (of learning and knowledge creation), and all other economic activity (including cinema halls, hotels, restaurants and groceries and so forth) will be spin-offs of and support the original knowledge activity. Hence LQ will enable us to distinguish the effects of basic employment (knowledge related in the context of university towns) and their multiplier effects.

Next, we intend to understand the economic base of university towns using other methods used by regional economists, in addition to LQs. Shift share analysis is a method which enables us to understand what part of employment growth in an industry of a city/town during a certain period was attributable to national economic growth, what share was because of growth in the particular industry/sector, and what part was due to the local area's growth. This is useful for purposes of identifying growth or potential growth industries that are worthy of further investigation.

In the context of university towns where knowledge is the main activity, we will understand if the employment growth during a certain period in the city was due to its local factors, availability of a pool of skills, growth in the academic/knowledge industry itself or merely a reflection of national economic growth.

Shift Share (SS) Analysis

SS examines economic change, whether growth or decline, in a city/region by decomposing the change into 3 components:
1. National share
2. Industrial mix
3. Regional share

While the measurement unit could be employment, income, output, value added or other factors, in this paper, employment will be used due to the availability of data at the city level from the Census of India which is published decennially. Given the limitations of census data, static rather than dynamic shift share analysis will be used.

Formally, we define the following terms for purposes of SS analysis.

Etr=Total employment of city $r$ at time t;

$\mathrm{Er}, \mathrm{t}+1=$ Total employment in city $r$ at time $\mathrm{t}+1$;

Etir=Employment in sector $i$ of city $r$ at time $t$;

Eir, $t+1=$ Employment in sector $\mathrm{i}$ of city $r$ at time $t+1$; 


$$
\begin{aligned}
& g n=\frac{E r, t+1-E t r}{E t r} \\
& g i r=\frac{E i r, t+1-\text { Etir }}{\text { Etir }}
\end{aligned}
$$

gir is the growth rate of industry $i$ in city $r$ over the period $t$ to $t+1 . G_{n}$ is the growth rate of total employment in the city over time period $t$ to $t+1$.

Etis $=$ Employment in sector $\mathrm{i}$ of reference area (here the state or the nation) at time $\mathrm{t} . \mathrm{Eis}, \mathrm{t}+1=$ Employment in sector $i$ of reference area (the state or the nation) at time $t+1$.

$$
\operatorname{gin}=\frac{\text { Ein, } \mathrm{t}+1-\text { Etin }}{\text { Etin }}
$$

Similarly, gis is the growth rate of industry $i$ in state $s$ (or reference region) over the period t to $t+1$.

gs is the growth of all industries (or of total employment) in the reference area, the state or the nation, in the context of this paper.

$$
g i s=\frac{\text { Eis, } \mathrm{t}+1-\text { Etis }}{\text { Etis }}
$$

National share (NS): This part measures the regional economic change that could have occurred in the city/region if it had grown at the same rate as the reference area (which is the state or the nation). It is defined as:

NS $=\Sigma$ Etir gs (gn)

The NS of each industry would inform how many jobs in the industry of the city during the period t to $t+1$ can be attributed to the overall growth of the state's (gs) or the country's economy (gn), as a whole.

Industry Mix (IM): This component measures the degree to which the local area is specialised in industries that are fast or slow growing nationally. In other words, it reflects the share of local economic (employment) change that can be attributed to the city's industry composition.

$\mathrm{IM}=\Sigma$ Etir (gin - gn);

where the difference (gin-gn) refers to the growth rate of the specific industry segment (gin) in the state or the nation, when compared with the state's (gs) or nation's overall economic growth (gn). 
Positive net values for IM indicate that the industry composition of the city contains faster growing industries. Negative results indicate the opposite.

Regional Share (RS): This component measures the change in a particular industry in the region due to the difference between the industry's local growth (or decline) rate (gir) and the industry's reference area growth rate (the state or the nation) (gis or gin).

$\mathrm{RS}=\Sigma$ Etir $($ gir - gin)

This component is the one which indicates the local area's specialisation in a particular good or service, which could be due to a natural resource, skill availability, existence of market, local consumption, savings, institutions, governance or local leadership. However, SS cannot help to identify what the local area/city's specific local advantage is, that is the basis of its specialisation. It only helps us to disaggregate the part of employment growth that is due to local (dis)advantages.

The total shift is the sum of the three component parts, and is equivalent to the employment change in the city over the said period for a specific sector.

The source of data for computing LQs and the shift share analyses is the Census of India economic (B) tables, since that reports information on main (as well as marginal workers for 2001) workers by industry sector at the level of the state and the urban agglomeration (in the Primary Census Abstract [PCA]).

The author will be in a position to report LQs and shift share analysis for selected university towns in India for 2001 Census, as the data needed for computation of these from the Census 2011 data were still not available, at the time of writing this paper.

\section{References}

Basant, R., \& Chandra, P. (2007). Role of educational and R\&D institutions in city clusters: An exploratory study of Bangalore and Pune regions in India. World Development, 35(6), 1037-1055. https://doi.org/10.1016/j.worlddev.2006.05.010

Brueckner, J. K. (2011). Why cities exist? Lectures on urban economics. (pp. 1-20). Cambridge, MA: MIT Press

Carlino, G. A., Chatterjee, S., \& Hunt, R. M. (2007). Urban density and the rate of invention. Journal of Urban Economics, 61(3), 389-419. https://doi.org/10.1016/j.jue.2006.08.003

Drucker, J., \& Goldstein, H. (2007). Assessing the regional economic development impacts of universities: A review of current approaches. International Regional Science Review, 30(1), 20-46. https://doi.org/10.1177\%2F0160017606296731

Garcia, R., Araujo, V., Mascarini, S., Gomes Santos, E., \& Costa, A. (2015). Looking at both sides: how specific characteristics of academic research groups and firms affect the geographical distance of university-industry linkages. Regional Studies, Regional Science, 
2(1), 518-534. https://doi.org/10.1080/21681376.2015.1099464

Kafouros, M., Wang, C., Piperopoulos, P., \& Zhang, M. (2015). Academic collaborations and firm innovation performance in China: The role of region-specific institutions. Research Policy, 44(3), 803-817.

Romer, P. M. (1986). Increasing returns and long-run growth. Journal of Political Economy, 94(5), 1002-1037. https://www.journals.uchicago.edu/doi/abs/10.1086/261420

Saxenian, A. (1996). Regional Advantage-Culture \& Competition in Silicon Valley and Route 128. Cambridge: Harvard University Press.

Sridhar, K. S. (2017). Economic Change And Specialization In India's Cities. Review of Urban \& Regional Development Studies, 29(1), 63-87. https://doi.org/10.1111/rurd.12059 


\section{Industrial agglomeration in a globalised economy: The case of Ahmedabad metropolitan area, India}

Anil Kumar Roy, Charmy Shah; CEPT University

\section{Introduction}

Developing economies are entering into a new era of urban and industrial agglomeration (The World Bank, 2009). It is traditionally observed that the countries transform from agricultural to industrial to service-oriented production and entrepreneurs. The rural labour forces leave behind their villages and enter into a labour market where economies of scale matter. This generally happens in either a large urban or industrial area. The synergies between and amongst the industries and urban areas gets strengthened in the process and visible impacts are observed in large urban areas. Hence, it is important to understand the linkages between and amongst the industries and configuration of urban areas, particularly metropolitan areas. (The World Bank, 2009)

The industrial sector, especially after liberalisation in 1991 and beyond in India, has integrated with globalisation by reorienting itself to face the challenges of increased competition both at the domestic and international levels. Industries have been and will have to adapt themselves to the rapidly changing needs of the market-driven economy where the government acts as a facilitator and not as a regulator. The prominent strategy for these industries, to sustain themselves and expand themselves into the global market, is to form agglomerations with due considerations of both positive and negative impacts (Deveshwar, 2014)

\section{Need for the study}

The major concern for urban areas in the process of globalisation is to understand how the smaller industries are going to adapt to the changing challenges of global and local competitions at the city level and evolve various strategies for survival. This may also mean that they need to reorient themselves to cater to the needs of the market in both the short and the long run. These industries use different survival strategies including complementing the large scale industries in the production process or creating synergies between other small scale industries (Bhatt, 2013). This leads to the formation of agglomeration of industries, and therefore it is vital to understand the process of agglomeration: a) how agglomerations are formed and b) what is the role of small scale industries in the formation of agglomeration, particularly in urban area?

\section{Research question and objectives}

The above concerns lead to the formation of our research question 'How do agglomerations help small scale industries to be linked with the globalised economy in Ahmedabad?' 
Following are the three major objectives:

- To understand the nature and typology of small scale industries in the selected industrial estate of Ahmedabad metropolitan city

- To study the economy of scale and their factors of agglomerations

- To examine the inter-dependence of agglomerations with the city, and how to sustain and expand them through planning interventions

\section{Methodology applied}

We have selected three industrial estates namely Naroda, Odhav and Vatva industrial estates of Ahmedabad Metropolitan City. The selection of these industrial estates is based on the size of operations and typology. The firms are largely small-scale and have been established during the early years of India's independence for employment generation and for supporting the diversity of economic activities of Ahmedabad. Each of these selected industrial estates specialises into specific products and exchanges their products between and amongst themselves. These small-scale industries are currently facing the various challenges of global competition. They have been trying to use economy of scale and are taking competitive advantages of informing an industrial agglomeration in the city. They are the three largest industrial agglomerations in the state. According to the report (Government of Gujarat, 2013), Ahmedabad has the highest number of registered small-scale industries (SSIs) in Gujarat, constituting 21 per cent of the SSIs at present in the state. Ahmedabad also gives a good opportunity for exports and imports through already established linkages with large urban centres within India and across the globe.

Based on the size and typology of industries that take advantage of economy of scale, Naroda, Vatva and Odhav industrial estates are selected to understand the various aspects of industrial agglomeration in Ahmedabad metropolitan city. After finding the number of industries of each type in three estates, more than 5 per cent of the dominant industries have been taken as the sample for further survey and analysis as given in Table 1.1. These samples are representative.

Table 3 Dominant types of industries and selected samples for the study

\begin{tabular}{|l|l|r|r|}
\hline \multicolumn{1}{|c|}{ Estate } & \multicolumn{1}{|c|}{ Type of Industries } & No. of Industries & \multicolumn{1}{c|}{$\begin{array}{l}\text { Sample of } \\
\text { Industries }\end{array}$} \\
\hline Naroda & Engineering Industries & 285 & 20 \\
\hline Vatva & Chemical Industries & 600 & 40 \\
\hline Odhav & Metal Industries & 143 & 10 \\
\hline \multicolumn{2}{|r|}{ Total } & $\mathbf{1 , 0 8 2}$ & $\mathbf{7 0}$ \\
\hline
\end{tabular}

Source: Naroda Industrial Association (NIA), Vatva Industrial Association (VIA) and Odhav Industrial Association (OIA), 2016 
An open-ended questionnaire for the stakeholders' consultation was prepared. The objective of the questionnaire was to understand the following aspects of agglomeration:

1. Factors for the location of the industries in Ahmedabad

2. Issues faced by these industries

3. Their survival strategies and

4. The various policies supporting them

This study has also identified the prime stakeholder of each estate. They are mainly the respective industrial estate's associations and the owners of selected industries in each of the three estates. Survey of the industries was done to understand different factors: a) availability of raw materials, b) production process, c) extent of labour market, d) use of technology, e) market for products, f) linkages with other industries and g) dependence on the association of their respective estates. A survey of association was done to understand the responsibilities of the association towards industries and how they affect the cluster of industries, what the common facilities are which are provided by the association for the industries and how the city government (Ahmedabad Municipal Corporation AMC) plays a role in this system.

\section{Major Findings}

There are four major factors which influence the location of these agglomerations near major urban centres: raw materials, labour market pooling, proximity to market and suppliers and technological spill overs (Maheshwari, 2013). Therefore, there is a strong influence of urban centres on the agglomerations based on these factors; further, the growth of agglomerations influences the economy of the city. This results into a symbiotic relationship between different industries in agglomerations and the urban centre. The study of these factors shows the dependency of the industries on other industries, association and the nearest located city. The study of economy of scale shows the influence of the urban centre located in close proximity on the industries present in the agglomeration in the case of Ahmedabad metropolitan city as well.

\section{Industrial Ecosystem in Ahmedabad}

A strong dealers' network for the procurement of raw materials is the most important factor for the engineering industries in Naroda as their raw materials are supplied from Gujarat and other states of India. Land is another important factor for their sustainability and growth. Although a rented plot of land will decrease the initial fixed capital, it restricts them from being a member of the Naroda Industrial Association (NIA). On the other hand, an industry with owned plot of land can be a member of NIA and can enjoy the common facilities provided by the association. The study finds that 90 per cent of the firms are located on their own plots in NIA.

Chemical Industries in the Vatva Industrial Estate are largely dependent on locally available raw materials. Products of one chemical industry are used as raw materials for the other 
chemical industries; this creates a demand for a strong network within the industries for the procurement of raw materials as well as for the selling of products. Moreover, the production process in chemical industries results into hazardous wastes which requires scientific disposal that is very expensive at an industrial level for small-scale industries. Therefore, presence of a Common Effluent Treatment Plant (CETP) and storage for hazardous materials as common facilities play a vital role in the growth of chemical industries in Vatva. There is a major requirement of unskilled and skilled labour to work in chemical industries, and the labour markets present in the nearby villages provide the required amount of labour.

The markets of Naroda and Vatva have been dependent on the export networks in the city as their products are exported to countries in Africa (Tanzania, Sudan, Libya) and Asia (China, Kuwait, Tajikistan, Kazakhstan) (as per Naroda and Vatva Industrial Association, 2016). More than 20 per cent of the engineering firms export their products while 15 per cent of the chemical firms export their products, and therefore, are influenced by the international markets for the required demand.

Metal industries in Odhav Industrial Estate require raw materials which are locally available and they are mostly dependent on Ahmedabad city and its hinterland. However, for marketing of their products, they need a strong network with large scale industries. The final products of the small scale industries are usually raw materials or intermediates for large scale industries. Most often, iron and steel scrap produced by the small industries is used as a secondary raw material by the large industries for steel production. Therefore, it is important for them to be in a cluster where there are strong linkages with other industries. There is a huge requirement of unskilled as well as skilled labour in the field of metal industries, which is a major benefit for the industries in Odhav as it is located in the proximity of Ahmedabad metropolitan city where a large labour market already exists.

\section{Factors affecting agglomeration of industries in Ahmedabad}

The factors which came up during the study of industrial ecosystem became the baseline for the analysis of the agglomerations as these factors determine the sustainability and growth of the agglomeration of industries. Majority of the raw material is contributed by the district and the state, and it requires a dealers' network, as they are mostly taken on one month credit. This dealers' network present in Ahmedabad is a major contributor towards the procurement of raw materials on one month credit.

There is a huge requirement of skilled and unskilled labourers, which they are able to get from the city and its hinterland through labour market pooling. For labour and basic infrastructure, Ahmedabad city and its respective industrial associations play a major role. The basic infrastructure including water supply, sewerage, drainage and roads is provided by the Naroda Utility Services (NUS), Vatva Industrial Estate Infrastructure Development Ltd. (VIEIDL) and Odhav Estate Infrastructure Ltd. (OEIL) respectively with the help of the Ahmedabad Municipal Corporation (AMC) (as per NIA, VIA and OIA, 2016). There is a 
technological spill over from the city and quicker spread of innovations among the firms within the same sector of industries with the help of the association as they are located close to each other, well within the Ahmedabad urban agglomeration.

The market, to sell the finished products of each of the industries in the selected estates, largely depends on the Ahmedabad metropolitan city. The government buyers in the city are a major advantage to the industries. The chemical fertilisers produced by the chemical industries are purchased by the Public Sector Units (PSUs) of the central government, such as the Hindustan Fertilizer Corporation Ltd, Rashtriya Chemicals and Fertilizers Ltd, and National Fertilizers Ltd, etc. The Medium, Small and Micro Enterprises (MSME) Development Institute, Ahmedabad is responsible for conducting buyer and seller meet and ancillary development on a regular basis to promote industrial networks. As products of industries can be used as raw materials for other industries, these industries are also dependent on the large- and medium-scale industries. The market of Naorda and Vatva industrial estates also expand to the industries present in other states of India, including major engineering industries present in Jharkhand, Madhya Pradesh and West Bengal which can be strengthened through this kind of networking.

\section{Sustainability of agglomeration}

The sustainability of agglomeration depends on two major factors: social benefits of smallscale industries and interdependence of agglomerations within the city. The presence of large firms in Ahmedabad has resulted in creating great innovations and ideas which are seen to be flown to the agglomerations of Naroda, Vatva and Odhav industrial estates. An agglomeration can only survive and grow if there is a strong support from the city government in terms of providing infrastructural facilities. AMC also plays an important role in giving financial assistance to the agglomeration by having an MoU with the associations and guaranteeing that 75 per cent of the property tax collected from the estate will be given back to the associations for the use of infrastructure development and upgradation creating common facilities.

These agglomerations are directly linked to the city system in terms of infrastructure, labour market, and markets for their products; any disruptions in the system will directly affect the industries present in the agglomerations. Ahmedabad metropolitan city is benefitting from the industrial agglomerations in terms of growing labour market, economic improvement and efficiency. The concentration of economic activity in the agglomerations are generally seen as giving rise to increasing returns that may be shared between the industries as well as the city.

\section{Conclusion}

Small-scale industries largely depend on locally available raw materials for their production and therefore prefer to be located where raw materials are easily available through a network of suppliers. This has been seen in the above mentioned three industrial agglomerations in the Ahmedabad metropolitan city. A major reason to agglomerate near a large city like 
Ahmedabad is to take advantage of the existing large labour pool present in the city. A good labour market in the vicinity (Ahmedabad and nearby villages) helps industries grow and the labour force also benefit from the agglomeration by means of good amount of opportunity of work.

Basic infrastructure facilities support the functioning of small-scale industries. Agglomerations of industries give an opportunity to have common facilities like water supply, waste management, roads, common facilities, storage, transportation, etc. at each of the industrial estates. The agglomeration of the units also helps in providing opportunities for research and development in terms of space and financial services in close proximity. All the factors of industrial location are present in these three industrial estates in Ahmedabad, hence their competitive advantages of cheap labour market; better financial support; networks of suppliers with credit facilities; availability of huge raw material sources; and the market for products within the hinterlands of the city, play a vital role in the formation of one of the India's largest industrial agglomerations of small-scale industries.

There are major stakeholders which can take advantage from the agglomerations. At the industry level, cooperation and networking between industries has to be made strong for supply and products' chain, and for sharing common resources and labour. At the cluster level, the association plays a major role for easy accessibility to the technological innovations done by the larger industry or by the research institute of the association. The local city government (AMC) supports the agglomerations by providing a strong infrastructure base which needs to be made stronger in Odhav Industrial Estate. Provisions given by AMC related to the labour market and market for products strengthen the potential of agglomerations. The settlement of industries in one region leads to positive agglomeration effects (external economies). Improved educational and employment opportunities, collective knowledge pools, and easier access to information and technology are the major advantages of clustering for sustainable regional development.

\section{References}

Awasthi, D. N., \& Kashyap, S. P. (2008). Emerging industrialisation process in Gujarat. In R. Swaminathan, (Ed). Gujarat: perspectives of the future (pp. 25-58). New Delhi: Academic Foundation.

Bhatt, T. P. (2013). Growth and structural changes in Indian industries (Working Paper No: 2013/02). New Delhi: Institute for Studies in Industrial Development.

Deveshwar, A. (2014). Globalisation: Impact on Indian small and medium Enterprises. The Business \& Management Review, 5(3), 136-147.

Institute of Small Enterprises and Development. (2013). Gujarat micro, small and medium enterprises report. Cochin: Paico Printing Press.

Karlsson, C. (Ed.). (2008). Handbook of research on innovation and clusters: Cases and policies

(Vol. 2). Cheltenham: Edward Elgar Publishing.

Mohan, R. (2006). Economic reforms in India: Where are we and where do we go?. In Lecture 
by Deputy Governor, Reserve Bank of India at a Public Seminar organized by Institute of South Asia Studies in Singapore.

Patil, S. G., \& Chaudhari, P. T. (2014). Problems of small scale industries in India. International Journal of Engineering and Management Research (IJEMR), 4(2), 19-21.

Personal Communication. (2016), President of Naroda and Vatva Industrial Associations respectively, March, 2016

Personal Communication. (2016), President of Naroda, Vatva and Odhav Industrial Associations respectively, March, 2016

PricewaterhouseCoopers. (2010). The Gujarat Vision: Making MSMEs globally competitive. Retrieved from https://www.pwc.in/assets/pdfs/publications-2010/msme_report.pdf

Solanki, T. K. (2014). District Industrial potentiality survey report of Ahmedabad district. Retrieved from http://www.msmediahmedabad.gov.in/download/district/AHMEDABAD.pdf

Suri, K. B. (1988). Small scale enterprises in industrial development: The Indian experience. Newbury Park: Sage Publications.

Uma, P. (2013). Role of SMEs in economic development in India. Asia Pacific Journal of Marketing and Management Review, 2(6), 120-126.

World Bank. (2009). World development report-2019: The changing nature of work. Retrieved from http://documents.worldbank.org/curated/en/816281518818814423/2019-WDRReport.pdf 


\section{Planning beyond boundaries for creating smart regions}

Vinita Yadav; School of Planning and Architecture, New Delhi

A region is a unit recognised by the Constitution of India. The 73rd and 74th Constitutional Amendment Act (CAA) envisaged a three-tier system of governance. Large cities in India are dependent upon regions for their sustenance. Usage of technology helps in integrating the administrative unit while preparing spatial plans. The expansion of cities beyond boundaries and ever expanding city limits are currently creating a situation where peri-urban areas in the periphery of cities, are becoming unmanageable. For governing such areas, regional plans are required. It is a known fact that preparation of plans has not kept pace with their requirement. The reasons range from non-availability of consolidated plans integrating both urban and rural areas by District Planning Committees (DPCs), lack of data assimilation and periodic updation, non-spatial and sectoral linkage of analysis, haphazard implementation of centrally sponsored schemes or centrally funded schemes, etc. Most of the programme implementation has differed from government to government.

The change in government policies and their implementation strategy has come with too little change on the ground. Learning from the implementation of earlier policies should serve as a backbone for future planning. However, in the current scenario, only modification the name of a strategy along with minor changes seems to be the approach of the government. Monitoring and evaluation of previous policies is key to the success of a programme. For monitoring and evaluation, the base data is required to assess the change in the conditions of residents. The team to monitor should be trained and committed to observe any deviance from the planned implementation. For evaluation, the focus shouldl be on both mid-term and end-term assessments. The learning from evaluation will then serve the base for future planning in the related project.

'Stakeholder Interaction' is generally a buzzword, but to turn it into reality, planning should encompass discussions with business groups, government officials, academics and civil society members. How to create a smart region is a mysterious query. Innovation in planning helps to focus on unresolved questions and adopt innovative solutions to find answers. Imaginative spirit of youngsters helps in start-ups, thus, increasing the self-employability of skilled manpower. Governance is complex at a regional scale as the consolidation of data assimilated at the rural and urban units require an innovative approach. The network relationship helps to understand the complexity of the situation. The interconnectedness and inter relationships between the city and its surrounding region can only be understood by engaging stakeholders in visioning. Citizens own prioritisation based on interactive workshops engaging multiple stakeholders. The intensive use of technology is a must for bringing inclusivity in the regional planning process. The relevance of a top-down approach of planning has lost its charm long ago. Instead, grass root planning helps us first plan for the lowest unit and then, move upwards by consolidating plans of all the units of a particular level. Thus, the 
plans from village to block to district to states can be compiled leading to balanced regional development.

Governance and institutional aspects are the most neglected part in governing city regions. Urban and rural areas require to be planned simultaneously after which a consolidated regional plan should be prepared. Gram panchayats are not equipped with resources or knowledge to prepare a plan incorporating both spatial and sectoral aspects. Transitional zones located in the periphery of large towns face larger consequences of such unplanned growth. The ever stoppable expansion of urban boundaries has engulfed the rural land and called them as 'developable areas', thus reducing the need to prepare a gram panchayat plan for such areas. For example, Faridabad metropolitan city is facing such an issue.

Increase in traffic congestion experienced in the extended urban regions is due to lack of planning. On the one hand, the congested core has mixed traffic and encroachment leading to traffic woes. The high rental values coupled with transportation problems are the main reasons behind people moving to suburban areas. Such suburban areas do not have municipal water supply, connected sewerage connection and full-time electricity supply. Regional infrastructure is a must before allowing the expansion of city boundaries.

A better quality of life requires both basic and advanced facilities. The current government's focus is on smart governance with the provision of energy, efficient lighting, verticle placement of plants for beautification, street signages for direction, and gyms in parks. This may define quality but in a country where many people are illiterate, with no employment opportunities, people enter the informal labour force. When the public does not have access to quality health and education infrastructure, provision of basic facilities should be the top priority. The focus on smartness by its applicability and utility should be judged before choosing ways to electronically implement projects.

The region's absorptive capacity differs substantially across spaces. In the initial period, the absorption power in the core areas far exceeds the periphery due to available resources. Once the core areas' capacity to absorb starts fizzling out, the dependence on the periphery due to the availability of vacant land and lessee land value starts gripping. The regional connectivity is felt important to connect the core with periphery by fast mode of transport systems. All such developments engulf productive agricultural land, thus, raising issues of sustainable development.

Regional innovation systems for governance involve applicability of smart technology, smart mobility, smart land governance and smart waste management, among others. Innovation is also bringing the focus on start-ups, skill building, mobile computing and electronic governance. From the first stage of just creating a website to two way correspondences through web applications, it is a long way for government. The process has already begun by creating a website to disseminate the information among masses as well as to apply for 
different services. A few departments like the passport department allow people to apply online and fix slots for physical verification of papers in order to save the overall time taken in applying and issuing the passport. The same is true for driving license and death and birth certificates among others.

To answer the question, 'how smart can a region be?' it is pertinent to focus on the interconnectedness and inter-relationship between the city and its surrounding region, on the one hand and interaction among varied stakeholders, on the other. The city is dependent on the region for meeting its daily requirement of vegetables, grains and milk. The city also serves peri-urban areas for newspaper, specialised services, higher order facilities and markets.

To leverage the city region potential, it is pertinent to define the quality and effectiveness of the regional innovation ecosystem. Ecological sensitive regions shall be protected using the latest geospatial technologies and GPS tracking for its inhabitants as well as a livable environment for those who live in the surrounding region. The regional innovation can be enhanced by interlinking different platforms for better connectedness. These platforms can then be used for business to business, business to government and people to business or government Interactions.

Local entrepreneurial activity helps in economic upliftment of the household process through interactive and innovative means. Weavers weaving cloth, artisans doing block printing, brassware work, stitching traditional attires are all getting their orders and delivering goods using e-platforms due to local entrepreneurship.

Diffusion of potential knowledge helps in balanced regional development as the regions located far away are also the ones receiving information. Hence, the creation of knowledge base and its dissemination will be a continuous process.

Competitiveness within these SMART regions is a must. The healthy city concept depends on a spree of facilities to improve the quality of citizens. Based on social capital, harnessing the capabilities of residents helps planners to realise citizens' potentials. Increase in the capabilities also means social and economic upliftment. The paper will attempt to deal with the issues explained above in much detail with the help of examples of smart applicability, smart infrastructure, smart mobility and smart land governance from different regions. 


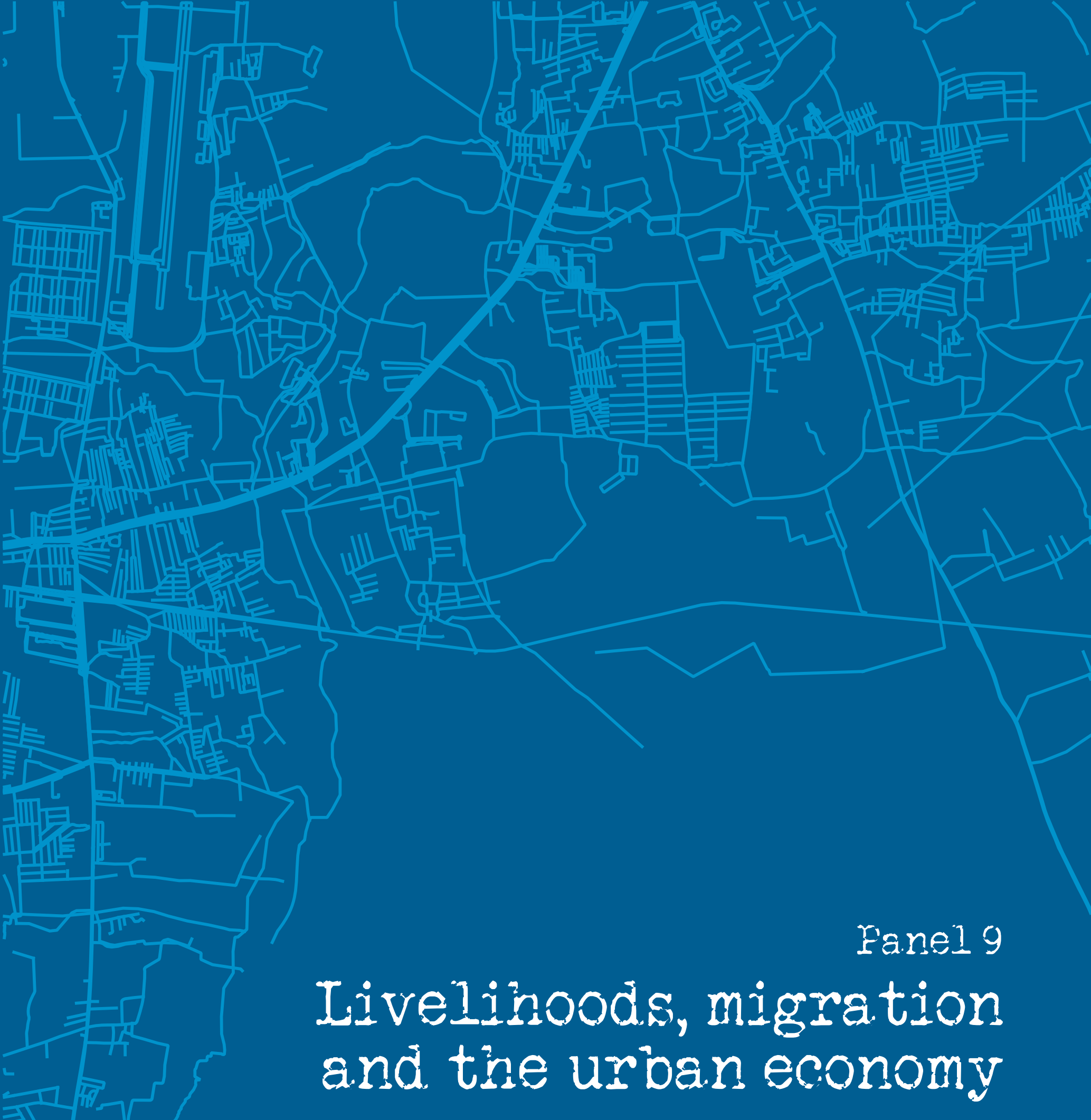




\section{'Feet in both places': Precarious migrant lives in a global city}

Swathi Shivanand; Jawaharlal Nehru University

Cities have their regions. Regions have their cities. The relationship between these two spatial entities has been a continuous but unstable one: some connections have thrived for centuries, some dissipated in a matter of decades, and some have had their surges and quiet periods. The region could perhaps be studied without the city; the city however, is forever indebted to the region for resources-infrastructural and people-that it has historically drawn from it, often to the latter's detriment.

Migration is one entry-point into studying this unequal relationship between the city and the region and it has indeed been used by several disciplinary frameworks to understand the ebbs and flows of people across centuries. Numbers have been counted, routes have been charted, movement patterns have been traced; these works have given us a tangible sense of the overall picture of migration, its impacts on the economies of the city and the region. The circularity of migration reminds us also of the enduring ties forged by such movement between the city and the region. Yet what is the experience of migration like? What does it mean to be a migrant, to have your 'feet in both places', as one of the interlocutors succinctly put it? Interpreting this experience of being in two places, of migration, is the burden of this paper.

The paper draws its material from oral history interviews conducted among poor migrants from the Hyderabad-Karnataka region, living in settlements in Bengaluru and working as construction labourers. The Hyderabad-Karnataka region is located in the north-east corner of the Karnataka state and has been considered to be 'historically underdeveloped'. This region was part of the erstwhile Hyderabad-Deccan state, ruled by the Nizams of the Asaf Jah dynasty up to the year 1956 and some of the poorest districts of the state, namely Gulbarga, Raichur, Bidar, Koppal and Yadgir constitute the region ${ }^{1}$. Labour migration from the region, particularly its rural parts, to Bengaluru, the prime urban centre and capital of the state, has been steadily increasing. As in other parts of the country, a large part of this migration is fuelled by the profitable construction industry. Census data indicates an increase in migration rates from 43 per cent to 48 per cent from the rural parts of this region to Bengaluru. Poor migrants from the region live scattered across the city and those with prior kinship and village networks that they can activate while here, live in slums. Although numbers are not available, anecdotal evidence suggests that many migrants live on construction worksites, on footpaths and other such precarious spaces in the city. While poor migrants from the region may be employed in other service sectors, a substantial presence is within the construction industry where women work as unskilled workers and men as unskilled, semi- skilled and skilled workers. 
Migrants from Hyderabad-Karnataka belong to the universe of internal migrants who form the vast army of labour evicted from the countryside to perform cheap labour for the service sector such as the construction industry and fuel the process of accumulation in the urban through conversion of land into real estate. But urbanisation, or city-making, in the current moment consists not only of urban sprawl and large infrastructural projects but also the proliferation of 'wastelands', including slum and squatter settlements. While one study in the 1970 s counted only 132 slums with a population of 132,000 in Bengaluru, a more recent study has claimed that more than 20 per cent of Bengaluru's population, i.e. about nine lakhs, live in approximately 450 slums in the city. In the context of migrating from an underdeveloped region to live in the 'wasteland' of a slum, it is important to ask: what is the experience of living in a divided city, where the spoils of a booming economy are unevenly shared? As migrant construction workers who live in informal settlements, interlocutors of this research, were best located to respond to this condition of life within the contemporary development regime.

This paper's central premise is that it is through the production of precarity that capital establishes and reproduces itself in the contemporary moment, and individual and collective efforts are geared towards mitigating precarity to the extent possible. The paper details the modalities through which precarity establishes itself in the intimate realm of experience and the tenuous ways in which it is challenged. While the specific meta-processes that produce precarity in the lives of the interlocutors are explained, the primary focus is on the discursive tropes and strategies people deploy to present the precarity of their lives and how it configures their existence. The verdict on whether migration widens or restricts the life chances of the migrant may stand divided between the enthusiasts and critics, but it is the contention of this paper that it only shifts the register of precarity, intensifies it even, as migrants move between the city and the region.

This precarity of life and work in unfamiliar environments is gendered, even as the family continues to be a site of accumulation. Migration decisions are often made familially with the patriarchal household, for instance determining how the distribution of sons and their wives between the city and the region needs to take place, at what times and places are women's labour needed. By focussing on women's narrations of migration and the ways in which their lives are determined by the circularity of this migration, the paper will argue that the farm and the village are the locus of patriarchal expectations and authority exercised over the woman migrant, whose labour has been transferred post-marriage to the husband. This is an advancement on existing scholarship which views agricultural lands and ties with the village as assets which facilitate the reproduction of labour in the city and perform the function of risk minimisation for the migrant household.

While gender is a primary axis along which the difference of experience is interpreted, the paper also explores the ineluctably spatial nature of the migrant's experience. First, the term desha is looked at and posited as a material-affective geographical entity, within which, 
migration when undertaken is believed to mitigate precarity. That is, it maps spatially the reluctance of migrants to travel outside an affective realm where precarity is heightened because of the unfamiliar. This shared realm does not quite refer to a territorial nation but evokes a sense of belongingness that the nation typically does. It references a familiarity akin to, but not the same as, the village. The desha is larger than the native village and is host to an imagined community bound together by linguistic, kinship and spatial affinities. For the interlocutors, over the decades, Bengaluru had become part of their desha, as village/regional environments were recreated in settlements they reside in.

Second, the interlocutors' articulations of neighbourliness in their settlements, the kinds of belonging with the city and the region that circular migration engenders are studied. Caught between the village that is the locus of everything familiar, but which can no longer sustain life, and the city, where residence is permanently temporary, a sense of community is hard to recreate. I look at the burden temporariness of this eviction and and its articulation as nostalgia and longing for the village, presented as a repository of affect. Yet, there is a constant struggle to find a permanent foothold in the city, be it in terms of ownership of tenements built by the state or retaining control over the now-valuable real-estate that they have settled on. I argue that while precarity affects belonging, belonging itself is articulated so as to assert a claim on the city.

Third, the interlocutors' position as casual workers in the construction industry is looked at and how this impermanence of employment is used to conduct life between the city and the region is studied. Migrants often withdrew from the hard labour of construction work to return to villages for short and long periods of time, to tend to farms, houses and relationships. They did so knowing that work would be available when they returned, since the construction industry has been on an upswing for decades now. Casual work leaves labourers in precarious positions, but it can be argued that this precarity is mitigated by using the very nature of this work -its casualness—by migrants to their benefit.

Unlike traditional oral history scholarship which focusses on events and memories built around it, the author's interviews with migrants were geared towards life histories. The conversations revolved around migration decisions, personal histories, living in informal settlements, working as construction labourers, and memories of, and choices offered by the village, among others. The city and the village formed the key co-ordinates for our conversations. The experiences narrated to are crucial to understanding life that takes place at the intersection of a globalising economy and a failing agrarian system and the efforts made to prop the latter. By examining the intimate effects of having life spread over different spatial contexts, the subjectivities that such mobilities produce, this paper will narrate a connected history of the region and the city. 


\section{Endnote}

1 Its nomenclature as underdeveloped comes from the characterisation of the Muslim state as 'feudal' and 'backward' in popular and state memory. At present though, activists have begun to locate its underdevelopment in the neglect faced by long years under ruling regimes in the composite state of Karnataka. As part of the author's larger work, the discursive history of this 'underdevelopment' of the region is explored. 


\section{Architecture and the urban setting of bazaar: Defining socio- economic city-region linkages in the process of urbanisation in India: A case of Mullickghat flower market, Kolkata}

Somrita Bandyopadhyay; School of Planning and Architecture, New Delhi

\section{Relevance of the topic}

A wholesale market is a forum which defines a larger economic transaction and a social and architectural construct for the gathering and exchange of goods as they are channelled from the source region into the city. They are the foundations of trade and are moulded by and a reflection of the prevalent political, economic and social norms.

In India, we have had the age old tradition of the 'haat bazaar' or the weekly market that would be set up in a specific site within the town or village, once or twice a week. Merchants and sellers would congregate from far and wide to display their wares and synonymously people from the entire region surrounding the town would attend. Thus, the bazaar signified a space of transience in its niche within the town which accommodated people from many places and walks of life who would periodically assemble in order to re-establish their long standing relationship, both commercial and communal.

These bazaars are a vital part of the larger urban agglomeration of trade in Kolkata, a city that grew along the river from industrial and mercantile origins into the thriving metropolis it is today. The river Hooghly forms the corridor that links the city to a greater region, further augmented and enhanced through the development of transit systems of rail and road. This chain of regions has a symbiotic relationship with the core and fortifies its commerce that in turn thrives on the social substructure of the wholesale markets or bazaars.

\section{Introduction and background}

The Indian bazaar, contrary to the strong associations of comfort and enclosure with the homes that we inhabit stimulates a psychological parallel with the 'outside' as a place that is innately perceived with mistrust: a space populated by strangers (Chakrabarty. D, 1992). As a result, emerges the significance of familiarity as the foundation of relationships formed at the bazaar. Familiarity creates a simulated zone, a security and takes the risk out of the economic transaction. Thus, people who are complete strangers in real life are hailed as brothers, sisters, uncles and aunts by shopkeepers and buyers, establishing a meaningful parody of our familial relationships and a deeper connection with the rhythms of our own life. '... unlike the modern marketplace, the bazaar is geared to the production of social life' (Chakrabarty. D, 1992)

These markets have historically sustained the city and created an avenue for its growth. Warehouses bordered along the river housed the goods to be transported. Rail-roads 
intercepted the points where the warehouses were located. The long stretched piece of land mass between the railroad and the waters came to be known as the riverfront edge. And beyond this edge began the central business district of Kolkata. Such development went on especially in the central part of the city which gained dominance as the industrial, and later the administrative centre for colonial India. As the river became the corridor for trade and commerce, a number of markets grew up alongside and in the vicinity of the river. These markets were collectively called Barabazaar and were largely wholesale and exchange markets which sold goods in bulks.

One such market within Barabazaar was the old Posta Bazaar where a prohibited opium trade was carried on by the British. Its location on the riverfront allowed the opium to be dispersed as soon as it landed on the docks, without any trace of its trade on the land. To ward off the strong smell of opium in and around the area, the British planned a flower market next to it. Flower also being a perishable product had to be sold immediately upon unloading. This flower market later grew into what was called the Mullick Ghat Phool Bazaar.

Situated on a long a strip of the riverfront, the flower market was named after the man who helped build it. One of the oldest markets of Kolkata, it is a topsy-turvy yet picturesque wholesale that runs strong even today. The market grew organically around the existing ghat structures that were built over the years and next to what is today known as the majestic Howrah Bridge. The old ghat structures still stand today and have become a living heritage. Beneath the fragrance of its wares, looms the mammoth market that is one of the largest in Asia.

\section{The research problem}

This research paper explores the market as an urban nexus that engenders linkages between the region and the city in the setting of Mullickghat flower market. As a product of its history and location, this market has many layers of meaning. Due to its location at the confluence of the transit lines of the city, the market demonstrates the advantages of the pattern of linkages with the greater region that sustains the floriculture trade. Like most markets in the city, it is run by communities of migrant workers and sets a unique example of the temporal nature of their habitation. The workers inhabit the live-in shops and have developed an underlying structure of residences and amenities intertwined with the market itself. Through its centuries of history and leading to its contemporary condition, it stands as a paradigm of the complex conglomeration of a community reflective of the changing social and political conditions.

\section{Aims and objectives}

The aim of the research is to examine the following domains and achieve the mentioned objectives:

1.) Transit: The market occupies a vital location at the intersection of important transit routes. This has helped sustain the largely perishable nature of the wares sold at the 
market and highlights the benefits of a well-planned juncture of trade. The changing nature of these transit systems, with the silting of the river that ultimately stopped the passage of ships; the transition of the Howrah bridge from a pontoon bridge to a steel giant; the changing of the adjoining freight train line to a local commuter train are some of the changes that have had the greatest impact on the market. Studying them reveals the innate connections between trade and transit over a larger geographical region.

2.) Architecture: The flower market is a testimony to coexistence and resilience. The market has grown organically into certain zones that may seem like a maze to the outsider, but is actually developed on a sound mapping of service and supply routes and clusters of different categories of flowers and other wares. Unlike the other markets of the central business district, this market is an entirely temporary structure. The temporary nature of the shops demands that they be reconstructed every few years. Though it is a monetary limitation, it has a positive side in that it gives the market an opportunity to redevelop itself and incorporate changes that cater to their present needs. Thus, the market is always growing and rejuvenating and it is this ease of upgradation that is a domain of enquiry for the development of newer trade nexuses being planned today.

3.) Migration: In general in the Barabazaar area, there is a large community of migrants. A majority of them come from neighbouring villages and states. The primary reason for migration is due to the rising problems with agriculture, susceptibility to drought and landlessness. All the thousands of businesses that run out of this area are greatly dependant on it to provide the labour force needed to carry loads and help in transportation. The flower market presents a very interesting and layered perspective on migration. The sellers have created temporary residences within the market and live in the city in rotating shifts. Another category of sellers visit the market in two-hour shifts. The load bearers are the only permanent residents who live in the large stretches of defunct industrial areas along the river. The women are conspicuous by their scarcity as they struggle to survive within a large male dominated market. The paper discusses these issues with respect to housing, gender and the social structure of these migrants and how it connects with a larger regional pattern of trade and cultivation of flowers.

4.) Political setting: The market has witnessed a great impact from the changing political scenario. Over the years, it has made a transition from a loose collective of shops to an integrated market, where its administration has shifted from socialist to bureaucratic. Thus, the research seeks to examine the effects of these changes on a sensitive juncture of the ecosystem of trade and society. 


\section{References}

Beattie, M. (2003). Colonial space: Health and modernity in Barabazaar, Kolkata. Traditional Dwellings and Settlements Review, 14(2), 7-19.

Bestor, T. C. (2001). Markets: Anthropological aspects. International Encyclopaedia of the Social and Behavioural Sciences, 9227-923. http://doi.org/10.1016/B0-08-043076-7/00907-4

Fligstein, N., \& Calder, R. (2015). Architecture of markets. In R. A. Scott \& S. M. Kosslyn (Eds.), Emerging trends in the social and behavioral sciences (pp. 1-14). Hoboken, USA: John Wiley \& Sons, Inc.

Chakrabarty. D. (1992). Of garbage, modernity and the citizen's gaze. Economic and Political Weekly, 27(10-11), 541-547.

Das, A. (2015). Demography, migration and economic condition of pavement dwellers: A study of most marginalized urban poor in central business areas of Kolkata, West Bengal. International Journal of Science and Research, 4(7), 1496-1501.

Fligstein, N., \& Dauter, L. (2007). The sociology of markets. The Annual Review of Sociology, 33, 105-128. http://doi.org/10.1146/annurev.soc.33.040406.131736

Glaeser, E. L., Ponzetto, G., \& Zou, Y. (2016). Urban networks: Connecting markets, people and ideas. Papers in Regional Science, 95(1), 17-59. http://doi.org/10.1111/pirs.12216

Seekumar, H., \& Varman, R. (2016). History of marketing in India. In D. G. Jones \& M. Tadajewski (Eds.), The Routledge Companion to Marketing History (pp. 389-401). London: Routledge. 


\section{Networks, mobilities and segmentation in small city labour markets}

Mukta Naik, Pranav Kuttaiah, Eesha Kunduri; Centre for Policy Research

In India and across the developing world, the focus of urban policy and scholarship has frequently revolved around large cities. India's urbanisation process is popularly imagined as a deluge of rural migrants flooding into large urban centres like Delhi-NCR, Mumbai, Kolkata, Chennai, Bengaluru in search of livelihood opportunities leading to notorious calls for antimigrant policies in broad popular conversation. In reality, the processes of structural transformation, urbanisation and economic development in India have always been far more complex: an intense, undulating mixture of rural and urban economic activity that refuses to obey any simple boundary between village and city. Shifting the gaze away from metropolitan contexts to small cities which are characterised by multiple migration pathways (Naik and Randolph, 2018), this paper attempts to understand how young people negotiate opportunities of employment and mobility in small city regions where the rural and urban, and even cities of varying sizes, are inter-connected and entangled. We therefore conceptualise this paper in the context of mobilities in small city regions.

In the early theories on industrialisation and modernisation (Lewis, 1954, Harris and Todaro, 1970), economic approaches have conceptualised migration in terms of individual economic rationality, wherein migrants are seen to be making rational and informed decisions driven by their self-interest. Marxist and structuralist theories, on the other hand, have conceptualised migration as an essential outcome of the transition to capitalism, and the only survival strategy for the poor after alienation from the land. Within a larger framework of capitalist accumulation, scholars writing in this tradition have focussed on the advantages that accrue to capitalists through the use of migrant labour (Mezzadri, 2008). More recent approaches, however, have departed significantly from these perspectives, and emphasised the need to see migration in a more positive light (De Haan, 2000). They have looked at migration as the manifestation of a complex decision-making process that is shaped by a multiplicity of factors: some individual, some social and some others institutional (De Haan, 2000; Ellis \& Freeman, 2005; Rigg, 2005). Migration, a social process, is shaped not only by the social structure (networks of community, and kith and kin), but in turn shapes it (De Haan, 2000).

In this complex interplay of individual and/or family decision-making and socio-economic structures and processes, this paper essentially seeks to understand how young migrants in non-metropolitan cities negotiate the labour market. Do young migrants make decisions in the labour market through processes of rational, economic, informed, individual self-interest? Or are their negotiations with the labour market largely influenced by larger 'group' decisions, structured and mediated by caste, community intermediaries, contractors, household patriarchs, and so on? What aspirations and expectations do such mobility decisions entail? How are these decisions shaped by the urban space of small-cities and concomitant transformations in the city as also the wider region? To what extent do factors like education, 
exposure, and specific caste location determine the kinds of work opportunities available for young people? Is the knowledge of jobs being available tied to community networks, and has this changed at all with improvements in communication technology? Has the idea of caste being an individual's only idea of the 'public' (Ambedkar, 2013) shifted considerably in negotiating strategies of mobility in India? If not mobility, do these factors at least contribute towards the ability to negotiate better working conditions?

The paper is based on quantitative and qualitative fieldwork in two small cities that vary in their scale, economic profile and regional context-Kishangarh in Rajasthan and Mangaluru in Karnataka. With a population of 154,886 as per the Census of India 2011, Kishangarh is a rapidly growing town in Rajasthan's Ajmer district located 18 miles north-west of Ajmer and well connected via the Indian Railways and National Highway 8. With the world's largest marble processing industry located here, Kishangarh has become an employment centre for unskilled rural youth from the villages nearby. At the same time, educated youth from the city look towards Ajmer, Jaipur and beyond for opportunities for higher education and work. The city continues to serve important functions as a mandi town, a transport hub, and an administrative centre for the sub-district, and is also becoming a centre for education for rural youth from nearby areas. It has also been the hub of infrastructural developments in the recent past-with a new bus stand, railway station and airport as well as upgraded railway infrastructure as part of the Dedicated Freight Corridor, which is a component of the Delhi Mumbai Industrial Corridor.

Mangaluru, on the other hand, is a port town in the Dakshina Kannada District of Karnataka that is home to 498,000 people as per the Census of India 2011. The city serves as a node in fairly old and established mobility networks that stretch from Kasargod in Kerala up the coast to Udupi and even Goa in the Konkan region. This 'strip urbanism' is made possible by road networks (particularly National Highway 17), the Konkan Railways and also in some cases via sea transport. Today, Mangaluru's economy is diverse, including fishing, industries like petrochemicals and agro-processing that are linked with the port, a number of hospitals and educational institutions and a nascent IT and ITES sector. Moreover, Mangaluru is an entrepreneurial city, and wholesale and retail trade are key sectors of the city's economy.

Both cities have segmented labour markets, wherein access to particular kinds of wage work and to specific entrepreneurial opportunities is intrinsically linked to networks and social capital. Kishangarh's industrial sector seems to offer a pathway for youth from rural backgrounds into non-farm work, but while commuter migrants from nearby villages who return home each evening are deployed in the skilled tasks of machine operators, long distance migrants from Bihar and Uttar Pradesh are engaged in low-end, low-paid manual labour like loading and unloading of cut marble slabs. At the same time, the marble and granite sector is built on local entrepreneurship by powerful business communities, organised along lines of religion and caste (Jains particularly). Entrepreneurship within the city as well as out-migration for education or work needs capital and networks, which are available only to a 
select few. In Mangaluru too, workers commuting on daily basis from areas such as Vithala, Uppinangady, Puttur, and Sullia are middlemen and contractors in various labour intensive jobs across sectors, as well as skilled industrial workers. They are considered 'locals' in a broad sense of the term, and most often speak both Tulu and Kannada. On the other hand, unskilled work, mostly in construction and manufacturing, is completely driven by inter-state migrants from Assam, Jharkhand, Uttar Pradesh, Bihar, and West Bengal, among others. There is a sense that the city is unable to offer satisfactory jobs to highly educated and enterprising Mangaloreans, who tend to migrate to metros or abroad for work. Regression analysis suggests that while the labour market returns for education differ by city: in Kishangarh, education does not impact wages but in Mangalore those with a university education earn better, caste is an important determinant of wages in both cases.

These findings raise a number of questions about the opportunities for young people entering the job market. Is the question one of 'job', in the sense of satisfactory employment; versus 'work', which one does to subsist but does not help one grow (Parry, 2013, Sen, 1984)? Is the shift from approaching employment as a function of larger identity practice to thinking about mobility as what is best for the individual connected to growth and entrepreneurship? Is that shift enough or does it require other forms of social, economic and cultural capital to translate into successful mobility (Kapur, Babu and Prasad, 2014), as the cases of success from Kishangarh and Mangaluru seem to indicate?

How do these considerations and aspirations translate spatially, especially when the small city is so closely interconnected with rural areas as well as other cites, smaller and larger, in the region? Is the city an agglomeration of jobs, goods and services, markets, and of opportunities, or is it a node in a larger, historically interlinked system that is adapting (perhaps even leveraging) older modes of movement and mobility to newer economic models without actually merging?

The cases of Kishangarh and Mangaluru show that it is not an either/or question. For any agglomeration to generate productive employment, service and trade opportunities, it cannot do so without network linkages-whether historical or contemporary. This is particularly so in case of small cities where the geography of the city is intrinsically tied to that of the region, even as newer linkages with relatively further places rapidly emerge and appear to deepen.

\section{References}

Ambedkar, B. R. (2013). Annihilation of caste: The annotated critical edition. New Delhi: Navayana Publishing.

de Haan, A. (2000). Migrants, livelihoods and rights: The relevance of migration in development policies (Social development working paper No. 4). Retrieved from https://www.researchgate.net/publication/252836337_Migrants_Livelihoods_and_Rights _The_Relevance_of_Migration_in_Development_Policies

Ellis, F., \& Freeman, H. (2005). Conceptual framework and overview of themes. In F.Ellis, \& H. 
Freeman (Eds.), Rural livelihoods and poverty reduction policies (pp.1-15) London, England: Routledge.

Harris, J. R., \& Todaro, M. P. (1970). Migration, unemployment and development: A two-sector analysis. The American economic review, 60(1), 126-142.

Kapur, D., Babu, D. S., \& Prasad, C. B. (2014). Defying the Odds: The rise of dalit entrepreneurs. New Delhi: Random House India.

Lewis, W. A. (1954). Economic development with unlimited supplies of labour. The manchester school, 22(2), 139-191. https://doi.org/10.1111/j.1467-9957.1954.tb00021.x

Mezzadri, A. (2008).The rise of neo-liberal globalization and the 'new old' social regulation of labor: A case of Delhi garment sector. Indian Journal of Labour Economics, 51(4), 603-618.

Naik, M., \& Randolph, G. (2018). Migration junctions in India and Indonesia reimagining places, reorienting policy. New Delhi: Centre for Policy Research. Retrieved from

http://www.cprindia.org/research/reports/migration-junctions-india-and-indonesiareimagining-places-reorienting-policy

Parry, J. (2013). Company and contract labour in a central Indian steel plant.

Economy and society, 42(3), 348-374. https://doi.org/10.1080/03085147.2013.772761

Rigg, J. (2005). Land, farming, livelihoods and poverty: Rethinking the links in the rural South. World Development, 34(1), 180-202. https://doi.org/10.1016/j.worlddev.2005.07.015

Sen, A. (1984). Resources, values and development. Cambridge, MA: Harvard University Press. 


\section{Planning strategies for upliftment of handicraft clusters and their workers: A case of Lucknow cluster of Avadh region}

\section{Amrita Rastogi; ISPER; Pratyoosh Madhavi; Nirma University}

Handicrafts is one of the contributors to the tertiary sector and to the GDP of India. The percentage share of per capita income of workers in this specific sector is gradually moving upward in last four decades. But since the past three years the number of workers in this sector has reduced. Why it has declined is the main research question of this study. The basic aim of this study is to suggest planning strategies for the upliftment of handicraft clusters and their workers. To achieve this aim, the first objective will be to study the existing status of clusters. Second, to study the basic profile and infrastructure of cluster. Next will be to review the socio-economic condition of workers. Finally, it will suggest interventions for cluster development and socio-economic improvement of workers. Uttar Pradesh ranks first in the handicraft sector compared to all other states. Handicrafts come under the small and cottage industrial household units which are mostly catered by the rural population. Uttar Pradesh is divided into four types of regions, all of which fall under the Handicraft Mega Cluster Mission (HMCM) where Lucknow falls in the Avadh region which has maximum number of handicraft clusters. There are two types of handicrafts: a) Terracotta and b) Chikkankari and Zari-zardozi. On the basis of the highest number of units and employment, Chikkankari handicraft was selected for this study. Chikkankari was started at the time of Mughals in 1860 and by 1990 it was flourishing. Lucknow has now emerged as the hub of Chikkankari. The craft itself is highly labour intensive and time consuming. Mostly, 95 per cent women of the Muslim OBC community participate in this work. Presently the condition of the clusters is very unfortunate, due to lack of wage enhancement, competition in market, seasonal products and lack of exposure of workers. Therefore, there is a need to study the development of these clusters and improvement of their workers.

The methods used during the primary survey are random sampling with 680 households (HHs) for a socioeconomic study and two units have been selected for detailed and comparative study; one is the most flourishing unit Chowk and another least flourishing unit is Chinhat, which is newly added in the Lucknow extension. Secondary data collection through various departments and focus group discussions has statistical analysis which was used to determine the location quotient. Additionally, theories and concepts from literature were used to frame the overall objective. After identifying the issues, some recommendations in terms of spatial and policy level for upliftment for the cluster and their workers have been suggested. Expressive recommendations for 2021 area demand the calculation for new units; a marked location for the future hub of Chikkankari; fabric waste management; to check pollution measures in the Gomti river; and an alternate route for improving the market potential. Formulation of an association body for the smooth running of a decentralised planned polycentric market was also suggested. Lastly, strategies were planned for the education of women and a skill training centre with social security for workers, which would help to improve their standard of living.

Keywords: Handicraft, Cluster, Workers, Units, Market etc 


\section{Building Healthy Cities: Reducing risk of diseases through multi- sector urban planning}

\section{Damodar Bachani; John Snow India Private Limited}

The burden of environmental and lifestyle diseases is rising in India's urban population, with dire implications for costs of care and mortality outcomes. The Building Healthy Cities (BHC) project is working with Indore Smart City Development Limited (ISCDL) to refocus their Smart City activities to reduce the underlying determinants of these diseases (largely noncommunicable, but also including some infectious diseases) while improving data-driven decision making. Planning for a Smart City is intrinsically linked to health: transportation, environment, sanitation, education, recreation, technology, and the built environment all influence the health of an urban population. When decision making and data systems across these areas are harmonised to focus on equitable access to healthy lifestyles, people will benefit from improved access to health services, decreased environmental and lifestyle risk factors for chronic diseases, a lower burden of infectious diseases, and wider access to data for decision- making.

As part of this social determinants of health approach, ISCDL identified the need to better understand the burden of non-communicable diseases in Indore. BHC and ISCDL jointly funded and conducted a community-based NCD risk factor survey for Indore, adopting protocol and tools used for the National STEPS Survey conducted in 2017-18, with support from All India Institute of Medical Sciences (AIIMS), New Delhi. BHC designed an additional module to be able to better understand the community-level built environment in each cluster, including types of roads, sidewalks, public transport, safety features, open spaces, food, tobacco and alcohol sellers and other physical determinants. The study was stratified to allow for comparison of slum and non-slum populations, representative to the city level. Data collection was carried out by trained investigators throughout May and June 2018. One adult aged 18 to 69 years per 3,000 households were surveyed, across 30 randomly selected wards. The environmental scan took place in 90 colonies across 30 wards.

Initial findings show that there are several behavioral and environmental risk factors affecting Indore residents. One in three adult males (37.2 per cent) were current tobacco users (smoking or smokeless). One in 10 adult males had consumed alcohol in the last 30 days. More than 90 per cent of surveyed population had inadequate (less than 5 servings) fruits and vegetables. One in 5 adults (22.4 per cent) added extra salt before eating food. One in 4 adults (23.9 per cent) were performing insufficient physical activity. Unhealthy diet and low physical activity resulted in overweight (27.3 per cent) and obesity (13.6 per cent) among adults; more so in women. The effect of high-risk behaviours was evident on health. Among the adults, 27.3 per cent had high blood pressure and 12.8 per cent had high fasting blood sugar. The difference between slum and non-slum residents was significant. Environmental factors were also analysed which show that residents in slum areas had low access to public transport and 
few functional sidewalks. Their health seeking behaviour towards NCDs was low. Less than 1 per cent of adults were never screened for common cancers like oral and cervical cancers. Additional analyses will be dictated by ISCDL and completed by BHC to tease out relationships between the built environment and risk factors like tobacco and alcohol use and facilities for physical activities.

The BHC project, in coordination with ISCDL and the Chief Medical and Health Officer, have planned multiple interventions to address these issues across the clinical, public health, and urban planning sectors. Some of these activities include development of strategies and material for behaviour change communication, orientation of city officers on provisions under Cigarettes and Other Tobacco Products Act (COTPA) to control tobacco use, building capacity of the public health system for screening for common NCDs, developing guidelines and tools for health promoting schools and training of teachers. Health ATMs are being installed under Smart City Mission at strategic points to encourage citizens to assess their risk profile. Built environment measures such as construction of new sidewalks, regulation of tobacco and alcohol sellers, coverage of open drains and air pollution monitoring are also being discussed for future activities, supplemented by data from another survey on the environmental health of Indore. These initiatives, coupled with strengthened data systems, can reduce the burden of non-communicable diseases in Indore. 
urban population: A technology-and innovation-driven model through a network of neighbourhood clinics (mohalla clinics) in Delhi

Anand Kumar Panjiyar', Rajesh Ranjan Singh', Karishma Srivastava1, Ruchi Jha1, Anuradha Jain ${ }^{2}$, Arvind Vashishta Rinkoo', Rahul Dev Bhawsar ${ }^{1}$, Divya Mishra ${ }^{1}$

\author{
${ }^{1}$ WISH Foundation India, ${ }^{2}$ USAID India
}

\title{
Background
}

India, same as the rest of the developing world, is urbanising rapidly. India's urban population grew by 31.2 per cent during the decade 1991-2001 which is significantly higher than the rural rate of 17.9 per cent. Population projections by the United Nations, Department of Economic and Social Affairs, Population Division (2018) indicate that by 2030, India's urban population will grow to 607 million with 40 per cent of the total population living in urban areas. Thus, India's success in achieving universal health coverage will largely depend on the extent to which the urban population gains access to affordable and quality healthcare. Urban health has emerged as one of the most significant health issues in terms of addressing a number of health needs among a large, diverse population. It becomes even more critical in an urban setting such as Delhi owing to factors such as high population density; a large number of slums and unnotified settlements; an enormous need to address non-communicable diseases attributable to modifiable lifestyle and environmental determinants; and the like. India has improved its performance on many health indicators through a holistic approach to health systems and institutional strengthening, leading to positive health outcomes such as reduced morbidity and mortality, and increased life expectancy and disability adjusted life years (DALYs). However, large gaps still remain in terms of absolute burden of disease largely attributable to maternal and child malnutrition, neonatal disorders, diarrhoea, lower respiratory infections, tuberculosis, and an ever-increasing disease burden on account of noncommunicable and environmental diseases. It is imperative to work towards a brighter, healthier future for urban population in India, especially in underserved peri-urban slums and related settings, and to redouble our efforts to reduce the burden of disease and promote equity in healthcare, as well as to increase individual and nationwide economic growth.

Large cities with enormous populations often show profound health disparities as large chunks of these populations belongs to the lower socioeconomic strata, living in overcrowded slums with poor sanitation and nutrition, inadequate waste management, and contaminated water supplies. The emerging epidemic of non-communicable diseases, closely linked to factors such as air pollution, unhealthy diet, physical inactivity, and traffic and domestic injuries, to name a few, further confounds the urban health ecosystem. The primary healthcare services for the urban poor remain largely neglected. Further, the capacity of 
service providers in assuring the delivery of quality healthcare is inadequate. This, in turn, results in extremely high burden on already overstretched tertiary care centres.

A widespread lack of health insurance compounds the healthcare challenges that India faces. According to the National Health Accounts Estimates, the Ministry of Health and Family Welfare, Government of India, 2014-15, the out of pocket expenditure of households (OOPE) accounts for 67 per cent of the total healthcare expenditure in the country. Markedly, this high level of OOPE by individual households in India is one of the highest amongst low and middle-income countries, thus ranking India low in terms of financial protection. In the absence of an adequate health insurance system, illness exposes households in India to the risk of financial catastrophe and in extreme cases, to poverty. Illness could cause severe financial hardship directly via healthcare payments and indirectly due to lost income from inability to work. Households with tight financial constraints may have no option but to cut spending on necessary goods to cover health expenses. Excessive reliance on OOPE may increase inequalities in access to healthcare and could also increase intergenerational inequality if the households' ability to invest in their children's health and education is reduced.

India's total healthcare expenditure is 3.89 per cent of its GDP (2014-15), out of which the government's (both centre and state) expenditure on health is 1.3 per cent of the total GDP (Ministry of Finance-Economic Survey 2015-16). The current expenditure of the government on healthcare is grossly inadequate to bridge the rising gap between provisioning basic amenities in the primary healthcare system and the increasing healthcare needs of the growing population. The government, through the National Health Policy 2017, envisions increasing public expenditure on health to 2.5 per cent of the GDP and decreasing the households' catastrophic health expenditure from the current levels by 25 per cent, by 2025. Universal health coverage aims to ensure that all individuals and communities, irrespective of their circumstances, receive the health services they need without enduring financial hardship. According to a study by Access Health International on primary healthcare in 2016, health expenditures are the cause of more than half of Indian households falling into poverty, estimated to be around 39 million people every year.

Delhi, with around 97.5 per cent of urban population, presents a unique opportunity to bolster reproductive, maternal, and child health outcomes by improving urban healthcare delivery mechanisms, especially in terms of easy physical access to health facilities and continuous availability of contraceptives and essential medicines. There is a growing body of evidence to suggest that migration of women workers to urban areas has overwhelmingly increased in recent years and most of these generally end up working in the unregulated sector; e.g. domestic workers, construction sites, bidi industry, as casual labourers, etc. These women have very limited access to various social welfare/protection schemes and quality healthcare services. This calls for a strategic approach aimed at strengthening public healthcare delivery infrastructure for providing quality and essential healthcare services to 
the urban population, including women workers, especially the large chunk of urban population living in underserved and vulnerable settings.

The Government of National Capital Territory of Delhi (GNCTD) remains committed to provide a range of preventive, promotive, curative, and rehabilitative health care services to the citizens of the state. It has a well-distributed network of dispensaries, polyclinics, and tertiary care centres (hospitals and medical colleges) that cater to the healthcare needs of the residents of Delhi, and also to those of the migratory and floating populations from the nearby states. Recognising the growing healthcare needs of its population, GNCTD proactively launched a state-wide flagship programme: Aam Aadmi Mohalla Clinic (AAMC) in 2015-16 to ensure delivery of quality primary healthcare facilities along with basic diagnostics. The first mohalla clinic was inaugurated on 19th July 2015. This strategic move was also aimed at reducing the OOPE for health services and at addressing the growing patient load at the specialist health facilities.

AAMC model uniquely leverages the power of technology, innovations, and partnerships to deliver quality primary healthcare to people from every strata of society at the doorstep by building a large network of clinics that provide patient-friendly, free medical care. Wadhwani Initiative for Sustainable Healthcare (WISH Foundation) is the flagship programme of Lords Education and Health Society and has rolled out the State Consortium to Accelerate, Leverage, and Economize (SCALE) platform in collaboration with the USAID-India to transform the primary healthcare system in the priority states, using healthcare technology and innovations. SCALE acts as the facilitating platform between the government, private sector organisations, innovators, social enterprises, and other healthcare ecosystem partners in bringing together financial and technical resources in catalysing integration of promising health innovations into the state public health system. In Delhi, WISH Foundation is the Knowledge Partner of GNCTD and supports the government to ensure efficient, cost effective, and sustainable functioning of mohalla clinics, delivering high quality client-centric services to the community with warmth and care. This paper showcases major interventions that are being delivered through the mohalla clinics and discusses initial outcomes in terms of improved health seeking behaviour and reduced OOPE for health services.

\section{Methods}

To start with, a thorough desk review/literature review was performed. Primary data was captured by doing a baseline assessment from July 2016 - August 2016. The objectives of the baseline assessment were to understand the health-seeking behaviour of the community living in the slums/catchment areas of the mohalla clinics and their experiences while receiving healthcare services, and to get an insight into the cost-incurred on health services and the level of client-satisfaction thereof. The study design included a mix of quantitative and qualitative approaches. The study population comprised of beneficiary households, community leaders, patients, and service providers as well as private practitioners in the catchment areas. The baseline study included interviews with 1,655 households and 45 
qualitative interviews/discussions which included in-depth discussions with the service providers and other stakeholders. Desk research looked into the database of health management information system (HMIS), managed by the National Health Mission, Ministry of Health and Family Welfare, Government of India and the database of mohalla clinics being recorded through the 'clinic management information system' for the period April 2016-March 2017 and for the period April 2017-March 2018.

\section{Results}

The baseline assessment revealed that the private doctor was the first point of contact for general ailments for a majority of the interviewed households (49 per cent). The first point of contact was the public hospital for 23 per cent of the interviewed households, public dispensary for 17 per cent, and private clinic/hospital for 11 per cent. Overall, the households that visited private healthcare providers for general ailments were 50 per cent higher than those that visited public service providers/facilities. Majority of the providers whom the households consulted for general ailments were offering necessary medicines and diagnostics services: 63 per cent households reported that necessary medicines were provided during consultation and 55 per cent reported that adequate diagnostic facilities were available at the first point of contact. A substantial proportion of the interviewed households (94 per cent) reported their satisfaction with the services provided by the healthcare provider at the first point of contact. However, on other parameters of clientsatisfaction such as money charged by the healthcare provider, waiting time at the healthcare facility, and distance travelled to access the healthcare provider, a fair proportion of respondents were either 'somewhat happy' or 'not happy'. The definition used for OOPE for health services in the 71st round of the National Sample Survey Office (NSSO) 2014 was used to determine the OOPE for health services in this study. The expenditure reported by the households for non-hospitalised treatment was ₹ 1,126 per household. Notably, the expenditure on diagnostic facilities was the highest, followed by that on medicines, doctor's consultation fee, and transport.

Findings from the desk research and the data gathered through the 'clinic management information system' of mohalla clinics suggest significant improvement in the uptake of services in Delhi. By the launch of state-wide network of mohalla clinics in 2016, the overall outpatient treatment in Delhi has increased by 16 per cent in 2016-17 and 19 per cent in 2017-18 (HMIS, National Health Mission, Ministry of Health and Family Welfare, Government of India), considering 2015-16 as the baseline. In 2016-17, mohalla clinics have provided treatment to 3.09 million clients (new and old) and in 2017-18, this number increased by as much as 22.32 per cent. This model has proven to be one of the best urban primary healthcare models and has received accolades at several national and international forums. Notably, it received SKOCH Order of Merit Award at the 52nd SKOCH Summit held in June 2018. 


\section{Conclusion/ The way forward}

The AAMC model is now fully engrained in the community ecosystem. Both the general population of Delhi and the service providers, have realised the intrinsic value of this unique initiative. Given the huge success of this technology- and innovation-driven model, Government of NCT of Delhi is gearing for its scale up by expanding the network of mohalla clinics.

Notably, Sustainable Development Goals (SDGs) include targets of achieving universal health coverage, including financial risk protection, access to quality essential healthcare services and access to safe, effective, quality, and affordable essential medicines, and vaccines for all. Evidence suggests that non-communicable diseases are the major cause of women-mortality globally (65 per cent) and the low- and middle-income countries such as India are the hub for majority of these deaths. Pregnant women comorbid with non-communicable diseases such as diabetes, anaemia, cancer, obesity, hypertensive pregnancy disorders, etc. are at a higher risk of developing childbirth-related complications, and their babies are more prone to experience adverse health outcomes later in life. Considering their huge potential, mohalla clinics can set an example in very near future as the most viable model globally to mitigate the adverse effects of non-communicable diseases on maternal health (and child health) through timely detection of these comorbidities in pregnant women. 


\section{PAHAL: An ecosystem approach}

LM Singh; IPE Global

\section{Background}

India has one of the poorest healthcare indicators when benchmarked with WHO standards. India's urban poor is the fastest growing population segment but is chronically underserved and vulnerable when it comes to basic services, especially healthcare, despite having the capacity to pay.

While India remains committed to achieving Universal Health Coverage (UHC) for all by 2030, it accounts for 21 per cent of the global disease burden ${ }^{1}$, but has one of the lowest health expenditures globally, at 4.8 per cent ${ }^{2}$ of the GDP (the world average is $\left.\sim 10 \%\right)^{3}$. Public expenditure on health is just over 1 per cent of GDP, one of the lowest globally, which has resulted in limited public healthcare facilities which are overloaded and inadequately equipped. The private sector controls 75 per cent of healthcare infrastructure in India. The low government spending on healthcare coupled with low penetration of health insurance in India, has resulted in high incidence of out of pocket expenditure (OOPE) on healthcare, at over 63 per cent (global average is $\sim 18$ per cent) ${ }^{4}$, which pushes over 39 million into poverty every year.

The disease pattern is changing rapidly, with an increasing shift from communicable to noncommunicable diseases. India stands to lose US \$ 4.58 trillion ${ }^{5}$ due to non-communicable diseases between 2012 and 2030. This has necessitated higher focus on preventive care and wellness. The private sector, with its vibrant entrepreneurial culture, has the potential to solve some of the health challenges of the urban poor. India's Base-of-Pyramid (BoP) population has a disposable income of more than US $\$ 358$ billion, which supports the case for private sector playing an even bigger role in the future, to address inclusive growth challenges and promoting sustainable development in healthcare.

As India's economy is strengthening, the country seeks new approaches to address development, thus making it a good time for exploring innovative financing solutions. Apart from the traditional ways of funding healthcare programmes through grants and donor money, the focus is increasingly shifting towards innovative financing mechanisms backed by private capital and often as a collaborative effort of public and private sources of capital. Innovative financing mechanisms in healthcare, including impact investments, impact bonds, credit facilities and affordable health insurance products can be used to achieve targeted results in a time bound manner to improve health outcomes. Non-traditional financial products that can go a long way in bringing efficiency into the interventions that are being carried out in health programmes across India. 


\section{The PAHAL programme}

PAHAL (Partnership for Affordable Health care Access and Longevity) is USAID/India and IPE Global's flagship innovations in financing platform. It seeks to catalyse innovative health financing models and provide technical assistance to Inclusive Business Models (IBMs) for improving access to affordable and quality healthcare solutions for the poor and vulnerable.

The PAHAL programme adopts an ecosystem approach to scale IBMs, by providing them with blended finance (debt, equity and grants), access to markets and technical assistance. PAHAL leverages the power of partnerships to deliver quality and affordable healthcare to the underserved. It has partnered marquee stakeholders including GE Healthcare, Dewan Housing Finance Limited (DHFL), Aditya Birla, PGIMER and healthcare providers. Through its network of partners, PAHAL has an unparalleled platform of 700 health facilities, 3000 doctors and 15,000 Community Health Workers (CHWs), reaching out to over 10 million people across 7 states.

The programme has the following four strategic interventions:

a) Credit expansion: To meet India's growing healthcare needs, financing is required for inclusive business models to build infrastructure, procure high end quality medical equipment, and scale operations required to deliver quality and affordable care to a large underserved population. The goal is to identify, structure and promote innovative debt financing mechanisms with a focus on lending to women enterprises in tier II and tier III cities. PAHAL has enabled a credit facility of $\$ 60$ million backed by the USAID DCA guarantee. It will enable IBMs to access debt through such facilities.

b) Blended finance solutions: The programme aims to catalyse new sources of capital and promote blended finance solutions for IBMs to deliver quality and affordable healthcare. PAHAL has set up the Pahal Health Fund, a Securities and Exchange Board of India (SEBI) registered Social Venture Fund, which will invest in scalable social enterprises to improve health outcomes for the poor. The fund will deploy returnable capital and impact over 20 million lives through its investments.

One of the non-traditional/innovative means of financing that is gaining traction around the globe to solve social problems is impact bonds. They are also termed as pay-for-performance instruments. Tuberculosis (TB) is a leading cause of morbidity and mortality in India. India accounts for the highest number of TB cases globally. It has been observed that India has large unfunded gaps in its TB programme which calls for pooling in of new sources of capital. The programme is thus supporting the structuring and rolling out of impact bonds focussing on Tuberculosis. It has partnered with two intermediaries: International Union against Lung Disease and Tuberculosis (The Union) and ChildFund India, to increase detection of TB cases, increase treatment adherence and improve the nutrition status of TB patients respectively. Through this 
intervention, the programme aims to reach out to 140,000 TB positive cases thereby leading to a reduction in TB burden in the country.

c) Risk Protection: Healthcare expenditure in India continues to be driven by OOPE which accounts for close to 63 per cent of total health expenditure. In contrast, the spending on pre-financed instruments like insurance accounts only for 8 per cent of the total healthcare expenditure. PAHAL seeks to promote innovative demand side financing and saving products to promote long-term savings, reduce the risk of financial shock borne by the poor because of unexpected healthcare needs and also promote preventive and primary care in order to reduce the risk of developing chronic illness in the future thus mitigating risk of high healthcare expenditure.

The project partnered with Aditya Birla Health Insurance Company to develop and roll out, through its network partners, a viable health financing product covering primary as well as secondary care. It is currently being piloted in five locations in Uttar Pradesh and Rajasthan.

d) Inclusive Business Model (IBM) Advisory: The programme works closely with IBMs to provide financial and business advisory, and linkages with the investors, funding institutions and philanthropic capital. In the past, PAHAL's advisory work included the following:

i. HLFPPT: Merrygold Health Network (MGHN), owned by HLFPPT, is the largest social franchising network focussed on maternal and childcare in India. PAHAL is providing technical assistance to help them attain scalability and sustainability.

- Developed and implemented community health worker trainings to improve efficacy and health seeking behaviour. The project successfully trained 405 community health workers.

- Developed a community centric branding strategy to increase brand recall

- Developed and deployed a prototype Health Management Information System (HMIS) to improve data collection and overall governance

- Prepared the financial model for HLFPPT with key growth drivers and proposed recommendations for enhancing access to healthcare and improving sustainability

ii. LifeSpring: LifeSpring Hospitals is a chain with 11 low-cost maternity clinics in Hyderabad and Visakhapatnam that operates on a no-frills model and stringent protocols.

- PAHAL supported LifeSpring to develop a community engagement model to expand capacity utilisation and take quality and affordable care to doorsteps of poor communities.

- Developed and deployed a technology solution to to increased transparency of operations at the field and improve overall governance. 
iii. Glocal: Glocal Healthcare Systems Private Limited ('Glocal') is a social venture that seeks to bring quality healthcare to the underserved population in India through an integrated model of comprehensive primary and secondary care hospitals and digital dispensaries or 'G1 Digital Dispensaries'.

- PAHAL provided business advisory for capital raise for expansion of operations

- Supported the expansion of technology enabled primary health units (G1 digital dispensaries)

iv. ikure TechSoft: iKure provides primary care through a network of 5 hubs and 110 spoke clinics, leveraging technology and community health workers in tier II and tier III towns of West Bengal, Bihar, Odisha, Jharkhand, Karnataka.

- Providing advisory for improving business model, raising capital for expansion and insurance expansion

PAHAL, in its capacity as a private sector-led urban healthcare initiative serves as a platform to promote innovative ways of deploying public, private, philanthropic capital to achieve goals of improving access to quality, affordable healthcare and reducing OOPE amongst urban poor.

\section{Endnotes}

${ }^{1}$ Bryan , V. C., Bird, J. L., 2016, Healthcare Community Synergism between Patients, Practitioners \& Researchers

2 NHA, World Health Organization, 2016

${ }^{3}$ NHA, World Health Organization, 2016

${ }^{4}$ Medical Technology: Shaping Healthcare for All in India, Deloitte-CII Report, 2017

${ }^{5}$ India to lose over $\$ 4.58$ tn to non-communicable diseases, The Business Standard 


\section{The challenge initiative for healthy cities (TCIHC-India)}

\section{Mukesh Kumar Sharma, Dr. Anuradha Jain, Vivek Sharma, George Philip}

\section{Background}

Urbanisation in India is rapid and is known as the 2-3-4-5 phenomena of population growth. It can further be described as for every 2 per cent rise in the country population, urban population records a growth of 3 per cent. At the same time, the mega city population grows by 4 per cent and most importantly, the slum population by 5 per cent. Considering this in mind and the rapid urbanisation in the country, it is important to provision the same rate of increase in urban health facilities. As per Census 2011 the total urban population in the country is more than 377 million, constituting 31.16 per cent of the total population which will be around 46 per cent by 2030. Census 2011 also reveals that there are 7,935 towns in the country which has increased by 2,774 towns since the last census in 2001 . The number of small towns is increasing at a faster pace.

\section{Introduction}

The Challenge Initiative for Healthy Cities (TCIHC)-India is co-funded by USAID and the Bill and Melinda Gates Foundation (BMGF) through MCSP and the Gates Institute funding mechanisms respectively. The project aims to reduce preventable child and maternal deaths by accelerating national urban health mission service delivery model through family planning and maternal and newborn health $(\mathrm{MNH})$ interventions. The project geography covers 31 cities in three states (20 cities in Uttar Pradesh, 8 cities in Madhya Pradesh and 3 cities in Odisha) and focusses more on slum communities. In addition, TCIHC provides technical assistance to the Urban Health programme of the national, state and city governments. TCIHC in India is helping the government to scale up proven evidence based high impact approaches to increase modern contraceptive prevalence and to increase the utilisation of MNH services among urban slum population.

\section{Methodology}

Proven high impact approaches were codified and converted into 'How To' tools. TCIHC, based on evidences ensured the activation of service delivery points near communities to reduce their out of pocket expenses (OOPE) and to ensure quality health services at doorsteps. In all three states and 31 cities, a resource team was deployed to work together with the local government and to activate provisioned service delivery model. Urban Primary Health Centres (UPHC), Urban Health and Nutrition Day (UHND) and Out Reach Camp (ORC) were activated in these geographies and coaches and mentors were deployed to support urban Accredited Social Health Activist (ASHA) by coaching them in the field. A systematic online project management information system (PMIS) was developed and used. Data was analysed and sent back to cities for decision making. The government was supported to plan, budget and execute the activities for urban poor. 


\section{Results}

All 31 project cities were activated in less than one year of period. Of the 509 urban health facilities, 405 (80 per cent) are now activated to provide family planning (FP) and MNH services. 4300 ASHAs are coached and 450,000 women are reached with quality counselling services. \$13.7 million in year two and over \$50 million in year three was unlocked through the government Programme Implementation Plan (PIP) process. 1620 fixed day static services for FP is being organised every month across the 31 cities and in six months of the period 255,000 women received a family planning service as per their choice. Intensive referral mechanism was tested in one city and ready to be scaled up in many more.

\section{Conclusion}

Activating existing government service delivery platform helps serving the most vulnerable population of urban India. It was also evident that in spite of activating all service components, a sharp focus on certain interventions (FP/MNH in this case) helps activating entire system. A skilled, trained and committed resource team is required to activate cities and facilities and coach government manpower. Using government resources increases the ownership in the government which leads towards sustainability. Continuum of care through systematic referral system ensures availability of services for urban poor at different layer of service delivery points.

\section{Replication potential}

The model is replicable as it requires very less investment and works on 80:20 rules. Cities need technical assistance as the national urban health mission is comparatively new and is full of technicalities. 


\section{Planetary urbanisation, region and India's Smart Cities Mission}

Glen David Kuecker, Tristan Stamets; DePauw University

\section{Research question}

This paper uses Henri Lefebvre's (2003 [1970]) planetary urbanisation to explore the relationship between region and India's Smart Cities Mission. The central research question considered is to what extent do scholars need to consider India's iteration of the smart city urban form as constituting a transitional moment in the relationship between the city and the region. The paper is part of an on-going research project looking into India's Smart Cities Mission (Kuecker, Stamets and Sarkulov forthcoming).

\section{Context and framing}

Facing an increased pace of rural to urban migration that promises to add an additional 300400 million city dwellers by 2050, it is clear that India's future largely depends upon what happens in its cities. Climate change, energy transition, food and water security, public health, ecology, economy, and politics all appear to be at their limits of sustainability, and all appear to find their solution or demise in India's urban future. The forces of this perfect storm of intense crises suggest that the foundational structures of the modern system are also in question a context that further suggests the crises may transform the constitutive concepts underlying modernity and give rise to an after modern epistemic (Kuecker, 2014). An analysis of this transition invites us to consider if the smart city is the form of urbanism generated by the contingences of the historical moment, a transitional or, perhaps liminal moment in the city that is neither fully modern but not yet after modern (Kuecker, 2013 and 2015).

\section{Theoretical positioning}

To think through the challenge of understanding the smart city at this historical moment, this paper turns to Henri Lefebvre's planetary urbanisation concept, especially the ideas presented in his 1970 publication, The Urban Revolution. From planetary urbanisation, the paper takes five key analytical propositions in its analysis of smart cities and region. These are: implosion/explosion; secondary circuit of capital; critical zone; blind field; and right to the city (Madden 2012; Merrifield 2005).

\section{Implosion/explosion}

The paper starts with Lefebvre's implosion/explosion and the recent explorations of the concept undertaken by Brenner (2017), whereby the former explains how rural migration leads to urban densification and how it drives the explosion of urban sprawl and periurbanisation. Densification also means that an explosion happens in urban metabolism as the city's tentacles extend to the far regions of the world seeking resources needed for the urban implosion. 


\section{Secondary circuit of capital}

Next, it considers Lefebvre's secondary circuit of capital, which draws our attention to how finance capital drives the logic of the Smart City Mission, and how the city not the factory has become the primary mechanism for capitalist reproduction (Harvey, 2012).

\section{Critical zone}

The more significant discussion of smart cities, however, occurs with Lefebvre's critical zone, which he imagines to be the urban form that evolves from modernity's industrial city toward the historical moment when the urban form becomes the central location of a planetary crises that transcends the perpetual crises of capitalist reproduction and becomes an existential threat to the modern iteration of civilisation. Seen as a bifurcation point of averting or succumbing to systemic collapse, the critical zone becomes a moment of instability rooted in the process of transformation in how humans live on earth. The paper explores a fundamental question: to what extent are smart cities the type of cities that humans build in the critical, or to what extent are they a post-critical zone urban form, a portent of the after modern urban reality?

\section{Blind field}

Lefebvre's 'blind field' invites consideration of what is made visible and invisible with India's Smart Cities Mission during the critical zone. It focusses on the challenge of understanding continuity and change within the smart city epistemic, especially the extent to which technocratic rationality and instrumental reasoning persist through the critical zone's process of departing modernity. This analysis of the smart city blind field invites consideration of what is made visible and invisible in the urban-region relationship as it is further transformed by the critical zone's mega-urban corridor, but also challenges the right of understanding the epistemic core of the region in the post-critical zone period.

\section{Right to the city}

Finally, the paper considers the relationship between smart cities and the changing meanings of region from the perspective of Lefebvre's right to the city (Harvey, 2008; Hodson \& Simon, 2009; Marcuse, 2009; Merrifield, 2011; Purcell, 2003 \& 2002; Samara, He, \& Chen, 2013; and Zárate, 2014). This analysis critiques the development community's expropriation and deradicalisation of the right to the city by offering analysis of how the critical zone informs an understanding of UN Habitat III's New Urban Agenda and its relationship to smart cities (Kuecker and Hartley, 2018). This analysis considers how we might approach understanding the revolutionary potential of the smart city, the post-critical zone.

\section{Contribution to thinking about urban-region relationship}

The paper's central contribution to this conference's interrogation of region is its critical urbanism perspective about the ways modernity's instrumental reasoning and technocratic rationality construct the social, political, economic, and cultural meaning of 'region', and how that understanding frames our thinking about India's Smart Cities Mission. This analysis is 
informed by the pioneering work of Datta's (2015a, 2015b, \& 2016) research on the Dholera smart city project and its relationship to the Delhi Mumbai Urban Corridor. But, this paper departs from Datta's valuable interrogation of smart cities and regions by positioning the theoretical problem of region within the challenge of conceptualising post-critical zone urbanism. The central hypothesis shaping this positioning holds that mega-urban corridorspartly understood from Khanna's analysis (2016)_displace the modernist construct of region in the post-critical zone era. The paper thus invites conference participants to consider if region is an anachronistic abstraction, and if so what the implications for thinking about India's 21 st century path forward are.

\section{References}

Brenner, N. (2017). Implosions - explosions: Towards a study of planetary urbanization. Berlin: Jovis.

Datta, A. (2015). The smart entrepreneurial city: Dholera and 100 other utopias in India. In S. Marvin, A., Luque-Ayala, \& C. McFarlane (Eds.), Smart urbanism: Utopian vision or false dawn? (pp. 52-70) London: Routledge.

Datta, A. (2015). New urban utopias of postcolonial India: Entrepreneurial urbanization in Dholera smart city, Gujarat. Dialogues in Human Geography, 5(1), 3-22. https://doi.org/10.1177/2043820614565748

Datta, A. (2015). A 100 smart cities, a 100 utopias. Dialogues in Human Geography, 5(1), 49-53. https://doi.org/10.1177/2043820614565750

Harvey, D. (2012). Rebel cities: From the right to the city to the urban revolution. New York: Verso books.

Harvey, D. (2008). The right to the city. New Left Review, 53, 23-40.

Hodson, M., \& Marvin, S. (2009). The right to the city: Energy and climate change. Critical Currents, 6, 70-78.

Khanna, P. (2016). Connectography: Mapping the future of global civilization, New York: Random House.

Kuecker, G. D., \& Hartley, K. (2018, March 13). No silver bullet: The new urban agenda and smart cities. Retrieved from https://www.fairobserver.com/more/global_change/new-urbanagenda-smart-cities-sustainable-development-climate-news-65431/

Kuecker, G. D., Stamets, T., \& Sarkulov, F. (2015). The technocratic delusion: India's smart cities mission. In K. Hartley, C. Phua \& J. J. Woo, (Eds.), Understanding cities in the Asian Century: Policy, space, and society. Routledge.

Kuecker, G. (2015). New Songdo city: A case study in complexity thinking and ubiquitous urban design. Proceedings of the 13th AESOP Planning and Complexity Thematic Group Meeting, Tampere, Finland, 15.-16. Jan 2015. 188-226.

Kuecker, G. D., (2015). New Songdo city: A bridge to the future? Case study in: The Second Assessment Report on Climate Change and Cities (ARC3-2).

Kuecker, G. D. (2014). The perfect storm: Catastrophic collapse in the 21st Century. In D. Humphreys \& S.S. Stober (Eds.), Transitions to sustainability: Theoretical debates for a changing planet (pp. 89-105). Champaign, IL: Common Ground Publishing LLC. 
Kuecker, G. D. (2013). South Korea's new Songdo city: From neo-liberal globalisation to the twentyfirst century green economy. Retrieved from https://www.ejks.org.uk/download/pages-2035-glen-david-kuecker-south-koreas-new-songdo-city-from-neo-liberal-globalisation-tothe-twenty-first-century-green-economy/

Lefebvre, H. (2003). The urban revolution. Minneapolis: University of Minnesota Press.

Madden, D. J. (2012). City becoming world: Nancy, Lefebvre and the global-urban imagination. Environment and Planning D: Society and Space, 30(5), 772-787.

Marcuse, P. (2009). From critical urban theory to the right to the city. City, 13(2-3), 185-197. https://doi.org/10.1080/13604810902982177

Merrifield, A. (2011). The right to the city and beyond: Notes on a Lefebvrian reconceptualization. City, 15(3-4), 473-481. https://doi.org/10.1080/13604813.2011.595116

Purcell, M. (2003). Citizenship and the right to the global city: Reimagining the capitalist world order. International Journal of Urban and Regional Research, 27(3), 564-590. https://doi.org/10.1111/1468-2427.00467

Purcell, M. (2002). Excavating Lefebvre: The right to the city and its urban politics of the inhabitant. GeoJournal, 58(2/3), 99-108.

https://doi.org/10.1023/B:GEJO.0000010829.62237.8f

Samara, T. R., He, S., \& Chen, G. (Eds.). (2013). Locating right to the city in the global south. London: Routledge.

Zarate, L. (2014.). The right to the city: Struggles and proposals for the urban reform. In H. Moksnes \& M. Melin (Eds.), Claiming the city civil society mobilisation by the urban poor. Uppsala, Sweden: Uppsala Centre for Sustainable Development. 


\section{Smart cities and citizenship}

Deepak Kumar; Jawaharlal Nehru University

The first question is what is meant by a 'smart city'. The answer is there is no universally accepted definition of a smart city. It means different things to different people. The conceptualisation of smart city, therefore, varies from city to city and country to country, depending on the level of development, willingness to change and reform, resources and aspirations of the city residents. A Smart City would have a different connotation in India than, say, Europe (emphasis added). Even in India, there is no one way of defining a smart city. ${ }^{1}$

This is how the Smart Cities Mission Statement and Guidelines by the Government of India, attempts to define a smart city. It says, without explaining how, it is different from its connotation in developed European nations. Largely, the idea of smart city, taking its cue from Europe and other Western nations is a technocratic endeavour to make cities economically more competitive (Burte, 2014). Without much clarity on what a smart city entails, it is largely understood to have a seamless reliance on technology to provide services in a few selected cities. The stated goal of the Smart Cities Mission in India, as per the mission guideline is to drive economic growth and improve the quality of life of people by enabling local area development and harnessing technology, especially technology that leads to smart outcomes. $^{2}$

On 25 June 2015, the Government of India (Gol) launched the Smart Cities Mission to develop 100 smart cities with an aim to provide basic services and better civic amenities with technological advancement in urban areas. It has two components: area-based development and pan-city development. For the selection of cities, competitions were held in different rounds and 100 cities were selected and allowed to implement projects for the development of smart cities, with financial allocation shared between the centre and the state. The selection of cities was based on a host of criteria including the manner of citizen engagement, functioning of the municipal body and its financial viability, visions and goals and ensuring convergence with other schemes of urban governance.

This experiment in urban governance on the lines of other European countries, as stated in India is different from the European model. It sounds promising but is not immune from creating challenges to sort out. What are these challenges? These challenges can be seen in terms of how urban spaces are claimed and reclaimed by its inhabitants, and their impact on citizenship rights i.e. the right to the city, deepening an identity of 'urban citizenship'. This results in the exclusion of those who are denied citizenship rights in such developed smart cities. One such case of denial of citizenship rights was the demolition of houses of 291 families living in informal settlements in Charan Khad in Dharamshala (Himachal Pradesh), one of the selected 100 cities to be developed as smart cities ${ }^{3}$. There are other reported cases of demolition of houses and violation of people's housing and other citizenship rights ${ }^{4}$, 
creating a gulf between those living in would-be smart cities and those out of it. Take another case of impact on citizenship rights with the development of smart cities in India. It was reported that 54 per cent of the households in Ajmer, Rajasthan and Jhansi, Uttar Pradesh: the two future smart cities, get their septic tanks manually cleaned, a practice of manual scavenging which is legally banned is still prevalent. ${ }^{5}$

The challenge is more immense on how to maintain a semblance between those at the receiving end of such development schemes and programmes and those that are excluded from accessing citizenship rights. According to studies by an advocacy group, there are severe challenges in terms of violation of human rights in the pursuit towards developing smart cities. There have been several reported cases of forced evictions and displacement of people due to infrastructure development, city beautification and smart city projects. ${ }^{6}$

In the European nations, according to a report, a majority of the countries including the cities of Paris, London, Dublin, Vienna, Barcelona and Brussels, homelessness is a challenge and it is reported that housing system in these places is under strain. ${ }^{7}$

According to the report, in all European countries, young people are more vulnerable to prohibitive housing costs, overcrowding and severe housing deprivation than the rest of the population. For poor young people across Europe, the situation is becoming increasingly prevalent, with 65 per cent in Germany, 78 per cent in Denmark and 58 per cent in the UK spending more than 40 per cent of their disposable income on housing. The average in EU is 48 per cent. In general, people living below the poverty threshold are 'increasingly marginalised by a private rental market that feeds off a systemic lack of affordable housing' ${ }^{8}$

The critique of smart cities has identified a lack of impetus on ensuring citizenship rights in the development of smart cities, creating grounds for the exploitation and denial of membership as a right to the city of such developed cities to the vulnerable groups, including those living in informal settlements for want of adequate living spaces as a result of gentrification. According to the study of some of the selected cities in India to be developed as smart cities, there is a serious lack of human rights-based approach which results in the denial of human rights to the wider poor and vulnerable segments who not only constitute the city but have been playing a crucial role in the development of critical infrastructure of such cities. ${ }^{9}$

Based on a survey of 23 cities in India, 'Annual Survey of India's City-Systems 2017', it has been highlighted that there is a lack of transparency and citizen participation in cities in India. ${ }^{10}$ The engagement between the government and citizens is weak owing to a lack of 'structured platforms for citizen participation', 'no coherent participatory processes', 'weak citizen grievance redressal mechanisms', and 'very low levels of transparency in finances and operations'.11 


\section{Proposed research}

Given the large-scale emphasis on building smart cities as engines of growth, with smart technology and assumed smart people to live in, how a smart city is governed 'smartly' and inhabited by different sections of people with their citizenship rights intact is what this paper seeks. This is important because not much scholarly attention has been given to the human rights-based approach to smart cities and how citizenship rights, including the right to the city, and right to privacy (India's Supreme Court in a judgment has affirmed that the right to privacy is a fundamental right ${ }^{12}$ ) of vulnerable sections would be fair in such cities. In this context, this paper aims to study how urban citizenship is getting more entrenched resulting in adverse and selective inclusion within so-called smart cities and the region outside smart cities. Smart cities will be used as a lens to understand the changing notion of citizenship (read urban citizenship).

\section{Research objective}

The paper explores how the notion of smart city and its impact on citizenship in terms of access to right to the city is understood and developed in India. At this preliminary stage, the attempt is to look at how smart cities in India entrench 'urban citizenship' rights and pit them against the rights of those who are vulnerable and fail to come within the category of 'urban citizenship,' in the absence of protection for the realisation of substantive citizenship rights (read social citizenship rights).

\section{Research question(s)}

Given some of the theories of citizenship and emphasis of the Indian government on creating smart cities, after taking a cue from the European nations but with a different approach to tackle the emerging challenge of urbanisation, and building infrastructure and basic services to its citizens, the paper examines what happens to citizenship rights of 'smart people' in the smart cities of India and those falling outside the smart city zones. To understand this better, the paper looks at how 'smart' people are identified and what does it entail to be smart people. These questions necessitate to looking into who live in future smart cities and their citizenship rights. The following preliminary questions would aid in an understanding of the larger question of the impact of smart cities on citizenship rights:

- What does it take to live in a smart city?

- How does the relationship of the state change with citizens of smart cities in terms of demands of rights and services and vice-versa?

\section{Research methodology}

The theoretical underpinnings of this research are theories of citizenship and critical theory. A secondary review of the development of 20 smart cities that were selected after the first round of the Smart Cities Challenge will be done. Media reports, official documents, research reports and studies, and conferences and seminars on smart cities will serve as material for the research study. Primary information through interviews of different stakeholders on the parameters of governance, citizen participation, access to basic services and other 
parameters may also be part of data collection. The changing notion of citizenship in the age of smart cities will be explored. The study also seeks to understand how the notion of smart cities deepens urban citizenship rights, resulting in the exclusion and denial of rights of vulnerable groups, including denial of right to shelter of those living in informal settlements in the absence of affirmative action of the state.

\section{Scope and limitations}

The idea of citizenship, in terms of membership and rights, at the present time of urbanisation and responses by nations to address these with programmes like Smart Cities, is creating grounds for the emergence of the identity of urban citizenship. This paper will look at the challenges in terms of citizenship rights in smart cities. The study will also attempt to highlight how the notion of smart cities actually reaffirms the right to city and a space for all inhabitants to live an enhanced quality of life and not results in the segregation and discrimination of those vulnerable groups for want of an adequate claim on the city and its resources, which currently the rich are able to claim and shape the city. This can be possible when the development of smart cities cover all and ensure spaces for different segments and with adequate design and planning for strengthening city-systems. The research will add to the emerging literature on smart cities and citizenship. It will mostly look at aspects of governance, citizen participation and exercise of their rights in accessing basic services, and housing in these cities. It will be limited in terms of doing a comprehensive analysis of all the aspects of city-systems.

\section{Research focus}

Citizenship ensures inclusion and provides rights. It has the force to create both inequality, and an effective tool to claim equality. It allows citizens to see the state, as Ruparelia says, 'through the enactment of social acts for welfare and hence brings transparency in state's action'. Devoid of citizenship, one is rendered stateless and excluded. Deep social inequalities and resultant exclusion result in the 'loss of the right to have rights' (Somers, 103). The citizenship rights entailing not only civil and political rights but also economic, social and cultural rights help build an egalitarian society. The paramount idea of social justice, liberty, equality and most importantly equity depend not only on recognition or acknowledgement of citizenship rights in its entirety but its enforcement with affirmative action of the state with adequate safeguard to protect the vulnerable and deprived sections of the society against the neo-liberal forces. Reducing social inequalities is crucial so that rights can be enjoyed, and social justice prevails. It is essential for the protection of the interest of the vulnerable and marginalised sections of the society from the vagaries of the market, capitalism and neoliberal forces. This research, therefore, attempts to look at linkages of urbanisation and citizenship rights at a time when steps are being undertaken to address the issue of urbanisation by building so-called smart cities as engines of growth. 


\section{Endnotes}

1 'Smart Cities: Mission Statement \& Guidelines', Ministry of Urban Development, Government of India, June 2015.

2 Ibid.

${ }_{3}$ Asher, Manshi. "Is There No Place for the Poor in Dharamshala "Smart" City?" Economic and Political Weekly.

${ }^{4}$ PTI. 2017. "Smart City-related evictions in India brutal: Medha Patkar," The Economics Times.

${ }^{5}$ The Wire Staff. 2018. "In Future 'Smart Cities' Ajmer and Jhansi, 54\% Household Septic Tanks Are Still Cleaned Manually," The Wire.

6 'India's Smart Cities Mission: Smart for Whom? Cities for Whom?,' New Delhi: Housing and Land Rights Network,

2017. Also see: 'Forced Evictions in India in 2017: An Alarming National Crisis' Fact Sheet, Housing and Land Rights Network, 2018.

7 “Homelessness and housing problems reach crisis point in all EU countries," The Guardian, 21 March 2017.

${ }^{8}$ Ibid.

9 'India's Smart Cities Mission: Smart for Whom? Cities for Whom?,' New Delhi: Housing and Land Rights Network, 2017.

${ }^{10}$ Annual Survey of India's City-Systems (ASICS) 2017: Janaagraha Centre for Citizenship and Democracy.

11 Ibid.

${ }^{12}$ Justice K.S. Puttaswamy (Retd) v. Union of India. WP (C) No. 494 of 2012.

\section{References}

Arendt, H. (2009). The decline of the nation-state and the end of the rights of man. In M. Goodale, (Ed.), Human rights: An anthropological reader. Hoboken, NJ: Wiley-Blackwell.

Burte, H. (2014). The smart city card. Economic and Political Weekly, 49(46), 22-25.

Caragliu, A., Bo, C. D., \& Nijkamp, P. (2011). Smart cities in Europe. Journal of Urban

Technology,18(2), 65-82. https://doi.org/10.1080/10630732.2011.601117

Chatterjee, P. (2004). The politics of the governed: Reflections on popular politics in most of the world. New York: Columbia University Press.

Chatterjee, P. (2008). Democracy and economic transformation in India. Economic \& Political Weekly, 43(16), 53-62..

Glenn, E. (2000). Citizenship and Inequality: Historical and global perspectives. Social Problems, 47(1), 1-20. Retrieved from https://www.jstor.org/stable/3097149

Harvey, D. (2012). Rebel cities: From the right to the city to the urban revolution. London: Verso Books.

Joss, S., Cook, M., \& Dayot, Y. (2017). Smart cities: Towards a new citizenship regime? A discourse analysis of the British smart city standard. Journal of Urban Technology, 24(4), 29-49. https://doi.oerg/10.1080/10630732.2017.1336027

King, D. S., \& Waldron, J. (1988). Citizenship, Social citizenship and the defence of welfare provision. British Journal of Political Science, 18(4), 415. 
https://doi.org/10.1017/S0007123400005202

Marshall, T. H. (1950). Citizenship and social class, and other essays. Cambridge, UK: Cambridge University Press.

Ruparelia, S. (2013). India's new rights agenda: Genesis, promises, risks. Pacific Affairs, 86(3), 569-590. https://doi.org/10.5509/2013863569

Sengupta, A. (2001). Right to development as a human right. Economic and Political Weekly, 2527-2536.

Somers, M. R. (2008). Genealogies of citizenship: Markets, statelessness, and the right to have rights. Cambridge, UK: Cambridge University Press.

Walzer, M. (1983). Spheres of justice: A defence of pluralism and equality. Oxford: Blackwell. 


\section{Smart cities programme, Schumpeterian logic or urban entrepreneurialism? Reading the governmentality of urban futures in India}

Purushottam Kesar; Department of Geography Planning and Environment, Radboud University

\section{Background}

The urban policy planning for Indian cities can be seen as a periodisation in managing the question of urban, which has been successively deployed through various public funded flagship programmes. The periodisation can be understood as a socio-poltico framing that has managed the question of urban futures through the installation of various imageries.

Notwithstanding the Smart Cities programme that seeks to leverage the use of technology to solve wicked problems in the post-2014 era, the programmes in the past have sought to limit rural-urban migration: Integrated Development of Small and Medium Towns Programme (IDSMT, 1979- 2005); a focus on Mega Cites in early 2000 (Mega Cities programme 1993-2005); and the most recent emphasising urban renewal through infrastructure improvement of million plus inhabited cities (JNNURM, 2005-2015). These programmes with the intended outcomes structure the gaze of the actors to seek solutions of the wicked problems of cities and therefore construct (structure) statecraft, politics and empirics of the practice. The deployment of such programmed imageries has intrigued scholars of the mentalities framing such regimes and the practices of the governance apparatus seeking to appropriate and negotiate the state space in the deployment of such imageries. A literature gap exists in understanding of the trialectics of framing (mentality)-apparatus (regime)-empirics (categories) and an omission into the insights such as structuration of discursive space and the anticipation properties of the urban system. An understanding of such processes can aid in answering public policy questions in managing developmental and political trajectories so as to structure affirmative urban futures.

In this paper, the particular mentality sought to elucidate is the question of the 'urban' i.e. the collectively held, rather collectively animated view on spatiality, which is deployed ('diffused and ubiquitous' tactics) to conform to stated practices and norms, interpret empirics and of its politics. The paper posits its analytical focus on mentalities framing contemporary projects of the urban in Indian cities, with an empirical case of the Smart Cities programme. An eponymous regime dictating discourses and everyday practice of the urban since its launch in 2014, now encompasses more than 100 cities. Situating within the geographical scope, the primary research question that is sought in this paper is - how Smart City Programme intervenes in the normative practices of governmentality of the urban? Then, there are two sub-questions: What are the mentalities that frame contemporary projects of the urban in Indian cities? And what is that collectively animated view on spatiality, which is deployed ('diffused and ubiquitous' tactics) to conform to stated practices and norms, to interpret empirics and of its politics? 
The paper proceeds by understanding governmentality of the urban, by reviewing the regimes of practices and its genealogy i.e. processes of its eventualisation; understanding the complex relationship between governance apparatus, and the production of newer categories to construct intelligible fields of intervention. The paper seeks insights into the conditionality that insists upon such programmes as well as accompanying rationalities and mentalities of policy makers. This is done by a review of notable works situated in the global South East such as 'subaltern urbanism' (Roy, 2009, 2011, 2011a, 2016; Spivak, 1999), 'state-space rescaling' (Ghertner, 2010, 2011, 2013; Sami, 2013; Shatkin and Vidyarthi, 2013), entrepreneurial urbanisation (Datta, 2016) and other related studies. These are studies which have tried to postulate practices which underline how 'calculated, reasoned prescriptions in terms of which institutions are to be recognised, space arranged and behaviors regulated' is an outcome of 'an assemblage of practices and related mentalities'. Post, through the empirical study are posited modes of governance at different scales (hierarchies): framing of Smart City guidelines at the national level (Ministry of Urban Development [MoUD], 2015) and preparation of Mangalore Smart City Project Proposal (Mangalore City Corporation [MCC], 2018). With a scaled enquiry of power at the aggregate and individual level, drawing on the theoretical framework of Governmentality (Foucault, 2007; Ettlinger, 2011; Dean 2010), the paper focusses on the interplay of macro-scale and individual practices.

\section{Research Methods}

The current research undertakes a thick description (Geertz, 1973) of two key documents i.e. 'Smart City Policy Document' (MoUD, 2015) and the Mangaluru 'Smart City Challenge Stage 2' (Mangaluru City Corporation [MCC], 2018) available in the public domain. Recursive rounds of interpretation were done to establish relational and persuasive attributes of disciplining applied for undertaking the Smart City project. An analysis of various utterances from the documents and reports (newspaper reports, media commentaries, stakeholder discussion) was done by using discourse analytic methods, seeking key categories of conceptualisation of the programme and points of argumentation (Hajer, 2006). In-depth interviews were conducted with key stakeholders.

\section{Initial Results}

While the paper tries to articulate governmentalities of urban, the theoretical focus can broadly be categorised into three modes; firstly, read as 'genealogies', secondly, analysed as 'discursively meditated' operating in recursive loops and thirdly underlining suspension of 'ontological status'. The three trajectories provide signposts in determining mentalities and intentions that are framing the projects of Urban. Further empirical studies offer instances of rescaling of the state space skirted with spatialisation practice, instances of worlding, deployment of affirmative metaphors plated with rhetoric of urgencies, developmental nexus, gold plating and so on.

The Smart City concept is understood as a political technological applicability in managing cities and its flows, in engendering a policy ecosystem that is based on recursive feedback 
loops of data through the use of ICT, AI. Increasingly cities are positioning Smart Cities as metaphors for clean investments, jobs and growth (Kitchin, 2014, 2015). However, academic scholarship is ambivalent at its 'pragmatic' and 'non-ideological' positioning in decision making as evidence suggests emphasis is on market-led criterions (i.e. economic feasibility) in selecting which wicked problems to address and concerns upon data for corporates (ownership), panoptic surveillance, social profiling, and social sorting.

Form utterances to formalisation into the urbanisation agenda and finally to the formal codification of the Smart City concept, mentalities situating this particular project of the urban include: firstly, political economy was sought in technologically-led urban entrepreneurialism (Macleod and Jones, 2011). Secondly, the hyphenation of rural-urban existed as political caution, suggesting the provincialisation of the concept due to the apparent ambiguity of the term Smart City. Thirdly, 'Worlding' (Roy and Ong, 2011) was deployed as an affirmation of its perceived success in Hong Kong and Shanghai. Lastly, a sediment view exists in the governance apparatus that urban is the new economy. The Smart City programme therefore situates in turf where governmentality is mediated to lay dominant claim over spatial production, the one that is symptomatic of the state's desire to play an active role in practicing urban entrepreneurialism.

The analysis of the processes and politics towards the codification of the smart city document and processes of implementation in cities (Mangaluru- empirical case) offer insights into the mentalities framing the Smart City programme. A mentality that that sees technology and infrastructure are essential attributes in fixating city-ness; where aggregate population is presupposed to fetish technology; infrastructure as essential parameters in deciphering cityness; it pushes in adopting a gaze of moderation rather resilience; the governmentality that dictates the conduct of the actors in selecting specific set of projects aimed at technological consumption and feasible returns; the emphasis is on one way delivery; and locating discursive space in deliberating the programme components in this case remained incapacitated.

The Smart City programme is hinged upon the Schumpeterian logic (in hindsight) that cities would attract investments, innovation enterprises and trickle down towards the creation of jobs; but in foresight it is urban entrepreneurialism. A subtle rescaling of the state space is underway that is changing the norms of citizenship-public participation (which now usually takes place through hackathons to solve wicked issues) and structuring the gaze of actors in identifying particular wicked problems. This gaze offers avenues for pursuing urban entrepreneurialism i.e. engaging with financially feasible wicked problems. The programme also fetishises consumption of technology wares and seeks citizens to be active participants in adapting to them.

These have implications and need interventions to lessen possible spinoffs of such interventions namely displacement, gentrification and livelihood losses, which has been 
observed in the empirical case of Mangaluru Smart City-Area Based Programme. The programme has induced a complex land real estate speculation leading to tensions around topics like livelihood losses, status of project beneficiaries, rehabilitation to name a few. A subtle displacement through misinformation (transactions have increased) can be observed.

The research vouches public policy interventions to reduce redundancies that creep in because of the particular gaze, a governmentality that seeks to manage the question of urban futures.

\section{References (Select):}

Dean, M. (2010). Governmentality: Power and rule in modern society. New Delhi: Sage.

Ettlinger, N. (2011). Governmentality as epistemology. Annals of the Association of American Geographers, 101(3), 537-560.

Foucault, M. (2007). The meshes of power. In J. W. Crampton \& S. Elden (Ed.), Space, knowledge and power: Foucault and geography (pp. 153-162). London: Routledge.

Geertz, C. (1973). The interpretation of cultures: Selected essays. New York: Basic Books.

Ghertner, D. A. (2010). Calculating without numbers: Aesthetic governmentality in Delhi's slums. Economy and Society, 39(2), 185-217. https://doi.org/10.1080/03085141003620147

Ghertner, D. A. (2011). Gentrifying the state, gentrifying participation: Elite governance programs in Delhi. International Journal of Urban and Regional Research, 35(3), 504-532. https://doi.org/10.1111/j.1468-2427.2011.01043.x

Ghertner, D. A. (2013). Gentrifying the State: Governance, participation, and the rise of middleclass power in Delhi. In G. Shatkin, (Ed.), Contesting the Indian city: global visions and the politics of the local (pp. 176-207). Chichester, West Sussex: Wiley Blackwell.

Hajer, M. A. (2006). Doing discourse analysis: Coalitions, practices, meaning. In v. d. Brink \& T. A. P. Metze (Eds.), Words matter in policy and planning: Discourse theory and method in the social sciences (pp. 65-74). Utrecht: NGS/KNAG/Nethur.

Kitchin, R. (2014). The real-time city? Big data and smart urbanism. GeoJournal, 79(1), 1-14. http://dx.doi.org/10.2139/ssrn.2289141

Kitchin, R. (2015). Making sense of smart cities: Addressing present shortcomings. Cambridge Journal of Regions, Economy and Society, 8(1), 131-136. https://doi.org/10.1093/cjres/rsu027

Ministry of Urban Development. (2015). Smart cities mission statement \& guidelines. Retrieved from http://smartcities.gov.in/content/innerpage/guidelines.php

Ministry of Urban Development (2018). The Smart city challenge stage 2: Smart city proposal New Delhi. Retrieved from https://smartnet.niua.org/content/1d466a09-ceed-4f1a-b90e2 afc3c363e77

MacLeod, G. (2011). Urban politics reconsidered: Growth machine to post-democratic city?. Urban Studies, 48(12), 2629-2660. https://doi.org/10.1177/0042098011415715

Roy, A. (2009). Civic governmentality: The politics of inclusion in Beirut and Mumbai. Antipode, 41(1), 159-179. https://doi.org/10.1111/j.1467-8330.2008.00660.x

Roy, A. (2011). Slumdog cities: Rethinking subaltern urbanism. International Journal of Urban 
and Regional Research, 35(2), 223-238.

Roy, A. (2011). Urbanisms, worlding practices and the theory of planning. Planning Theory, 10(1), 6-15. https://doi.org/10.1177/1473095210386065

Roy, A. (2016). What is urban about critical urban theory?. Urban Geography, 37(6), 810-823. https://doi.org/10.1080/02723638.2015.1105485

Roy, A., \& Ong, A. (Eds.). (2011). Worlding cities: Asian experiments and the art of being global. Chichester, West Sussex: Wiley Blackwell.

Sami, N. (2014). Power to the People? A study of Bangalore's Urban Task Forces. In Shatkin, G. (Ed.), Contesting the Indian city: Global visions and the politics of the local (pp. 121-144). West Sussex, UK: Wiley Blackwell.

Shatkin, G., \& Vidyarthi, S. (2014). Introduction: Contesting the Indian city: Global visions and the politics of the local. In Shatkin, G. (Ed.), Contesting the Indian city: Global visions and the politics of the local (pp. 1-38). West Sussex, UK: Wiley Blackwell.

Spivak, G. C. (1999). A critique of postcolonial reason. Cambridge, MA: Harvard University Press.

Swyngedouw, E. (2009). The antinomies of the postpolitical city: In search of a democratic politics of environmental production. International Journal of Urban and Regional Research, 33(3), 601-620. https://doi.org/10.1111/j.1468-2427.2009.00859.x 

